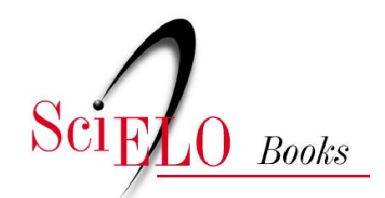

\title{
O direito à natureza na cidade
}

\author{
Wendel Henrique
}

SciELO Books / SciELO Livros / SciELO Libros

HENRIQUE, W. O direito à natureza na cidade. Salvador: EDUFBA, 2009. 186 p. ISBN 978-85-

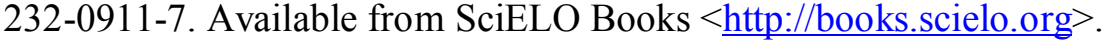

\section{(c) $(9)$}

All the contents of this chapter, except where otherwise noted, is licensed under a Creative Commons Attribution-Non Commercial-ShareAlike 3.0 Unported.

Todo o conteúdo deste capítulo, exceto quando houver ressalva, é publicado sob a licença Creative Commons Atribuição - Uso Não Comercial - Partilha nos Mesmos Termos 3.0 Não adaptada.

Todo el contenido de este capítulo, excepto donde se indique lo contrario, está bajo licencia de la licencia Creative Commons Reconocimento-NoComercial-CompartirIgual 3.0 Unported. 


\section{O DIREITO À NATUREZA NA CIDADE}




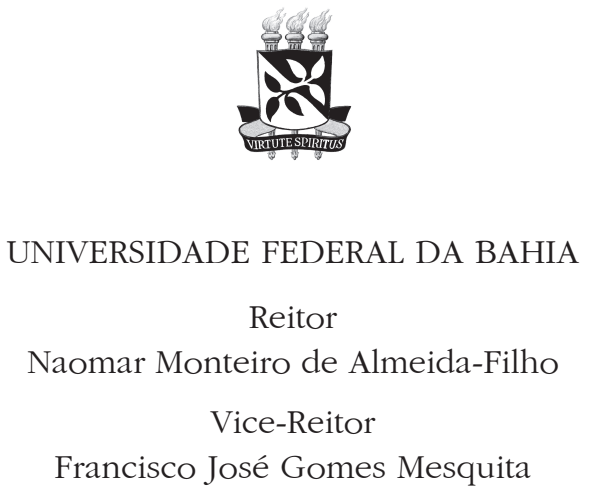

EDITORA DA UNIVERSIDADE FEDERAL DA BAHIA

Diretora

Flávia Goullart Mota Garcia Rosa

Conselho Editorial

Titulares

Ângelo Szaniecki Perret Serpa

Caiuby Alves da Costa

Charbel Ninõ El-Hani

Dante Eustachio Lucchesi Ramacciotti

José Teixeira Cavalcante Filho

Maria do Carmo Soares Freitas

Suplentes

Alberto Brum Novaes

Antônio Fernando Guerreiro de Freitas

Armindo Jorge de Carvalho Bião

Evelina de Carvalho Sá Hoisel

Cleise Furtado Mendes

Maria Vidal de Negreiros Camargo 


\section{Wendel Henrique}

\section{O DIREITO À NATUREZA \\ NA CIDADE}

Salvador

Edufba

2009 
(C)2009, By Wendel Henrique.

Direitos de edição cedidos à

Editora da Universidade Federal da Bahia - EDUFBA

Feito o depósito legal.

Revisão

Tânia Aragão

Editoração Eletrônica e Capa

Rodrigo Oyarzábal Schlabitz

Sistema de Bibliotecas - UFBA

Henrique, Wendel.

O direito à natureza na cidade / Wendel Henrique. - Salvador : EDUFBA, 2009.

$186 \mathrm{p}$.

ISBN 978-85-232-0615-4

1. Geografia urbana. 2. Homem - Influência sobre a natureza. 3. Homem. 4. Ecologia humana. I. Título.

CDD - 307.76

EDUFBA

Rua Barão de Jeremoabo, s/n - Campus de Ondina,

40170-115 Salvador-BA

Tel/fax: (71) 3283-6164

www.edufba.ufba.br edufba@ufba.br 
À minha mãe, Maria Leonilde Baumgartner Henrique, pelo amor, pela liberdade, pela coragem e pela independência. 



\section{SUMÁRIO}

PREFÁCIO / 9

APRESENTAÇÃO / 13

I - A CIDADE E A NATUREZA / 17

II - UMA PERIODIZAÇÃO PARA COMPREENDER AS RELAÇÕES ENTRE A CIDADE

E A NATUREZA / 29

UMA PROPOSTA / 31

\section{PARTE I - A INCORPORAÇÃO DA NATUREZA À VIDA SOCIAL}

III - A NATUREZA E O HOMEM / 37

O PERÍODO CLÁSSICO / 37

INTERPRETAÇÃO E CONTEMPLAÇÃO DA NATUREZA / 40

A CRIAÇÃO DE UMA SEGUNDA NATUREZA - MARCUS TULLIUS CÍCERO E OS

ESTÓICOS / 42

O PERÍODO TEOLÓGICO / 45

BASES TEOLÓGICAS / 46

O DOMÍNIO DO HOMEM SOBRE A NATUREZA / 50

IV - O HOMEM E A NATUREZA / 57

O PERÍODO DOS DESCOBRIMENTOS / 57

O INÍCIO DO PERÍODO DOS DESCOBRIMENTOS / 58

CONHECER, EXPERIMENTAR, REPRODUZIR E FABRICAR A NATUREZA / 60

A NATUREZA ORGANICISTA / 63

A ÉPOCA DO HOMEM NA HISTÓRIA DA NATUREZA / 64

O PERÍODO DA INCORPORAÇÃO / 67

A INCORPORAÇÃO DA NATUREZA PELO TRABALHO DO HOMEM - KARL MARX / 68 A DIALÉTICA DA NATUREZA - FRIEDRICH ENGELS / 74

A INCORPORAÇÃO GEOGRÁFICA DA NATUREZA. A AÇÃO DO HOMEM E UMA NOVA GEOGRAFIA FÍSICA - GEORGE MARSH / 76

O HOMEM, A TERRA E O SENTIMENTO DA NATUREZA - ÉLISÉE RECLUS / 80

V - O HOMEM E O TERRITÓRIO / 93

UMA NATUREZA TECNIFICADA / 97

AS REFERÊNCIAS À NATUREZA / 101

A "DISNEYFICAÇÃO" DA NATUREZA / 104

A VALORIZAÇÃO DA NATUREZA / 107 


\section{PARTE II - A NATUREZA NA CIDADE E SUA APROPRIAÇÃO PELOS EMPREENDIMENTOS IMOBILIÁRIOS}

VI - A NATUREZA NA CIDADE / 117 DO JARDIM FORMAL AO JARDIM INGLÊS - A NATUREZA TOMA SEU LUGAR NA CIDADE / 119 A NATUREZA NA CIDADE COMO ATRATIVO IMOBILIÁRIO / 125 AS FORMAS DO URBANISMO E A QUESTÃO DA NATUREZA NA CIDADE / 129

VII - UM BOSQUE PARA CHAMAR DE MEU. A APROPRIAÇÃO DAS IDEIAS DE NATUREZA PELOS EMPREENDIMENTOS IMOBILIÁRIOS / 139 SÃO PAULO - A SOFISTICAÇÃO DA NATUREZA / 141 A FELICIDADE NÃO TEM PREÇO, TEM ENDEREÇO - FLORIANÓPOLIS/SC / 147 VIVER COM ESTILO NO JARDIM TROPICAL - SALVADOR/BA / 151

VIII - O DIREITO À NATUREZA NA CIDADE. DA (DES)IDEOLOGIZAÇÃO DA PRÁTICA PARA A CONSCIÊNCIA CRÍTICA DA PRAXIS NA RELAÇÃO COM A NATUREZA / 165

A CRÍTICA - DESVELANDO A IDEOLOGIA DA PRÁTICA ALIENADA / 165 OS PRINCÍPIOS - PARA UMA NOVA PRÁXIS NA RELAÇÃO COM A NATUREZA, A NATUREZA PARA O CIDADÃO E NÃO PARA O CONSUMIDOR / 167 O PROJETO - UM NOVO DESÍGNIO: REPENSAR A CIDADE É REPENSAR O LUGAR DA NATUREZA NA CIDADE / 169 A AÇÃO - UM PARQUE URBANO PARA O USO COLETIVO DA NATUREZA NA CIDADE / 172

REFERÊNCIAS / 179 


\section{PREFÁCIO}

Ferreira Gullar, em as Coisas da Terra, fala que todas elas "estão na cidade entre o céu e a Terra. São todas elas coisas perecíveis[...] Mas é nelas que te vejo pulsando, mundo novo, ainda em estado de soluços e esperança”. Pessoas, natureza, cidade, emancipação... Palavras... momentos, períodos. O autor deste livro, na busca de uma tessitura plural, adensa em frases e orações, caminhadas, mudanças, sonhos e desejos de uma natureza na cidade - onde se concentra a maioria da população no mundo contemporâneo - entrecruzada por outras possibilidades de uso que não somente aquela regulada pelo consumo e pelo individualismo. A investigação em O Direito à Natureza na Cidade organiza-se em duas partes: "Incorporação da natureza à vida social" e "A natureza na cidade e sua apropriação pelos empreendimentos imobiliários" - dimensões basilares na estruturação desta obra que traz, além de referências clássicas e contemporâneas vinculadas à Geografia, leituras outras, do campo da Filosofia e Sociologia.

A primeira parte, "A incorporação da natureza à vida social", apresenta e discute por meio de três grandes momentos - a saber: "A natureza e o homem", "O homem e a natureza" e "O homem e o território"-, as modificações nas concepções de natureza pelos homens e mulheres e, por conseguinte, a apropriação que será feita desta natureza. O autor, ao discorrer sobre "A natureza e o homem", subdivideo em outros dois períodos: Clássico e Teológico. No primeiro, a concepção predominante de natureza refere-se ao mito, manifestada pela literatura através de um viés contemplativo. O período Teológico, marcado por uma natureza divina, terá na Bíblia a materialização da relação Homem/Natureza, associada ao temor. Em "O homem e a natureza", o autor advoga em prol da ideia que o Homem regulará os entraves impostos pela natureza, fato que o leva a definir os períodos dos Descobrimentos e da Incorporação. As concepções de natureza que alicerçarão o período dos Descobrimentos serão fisicoteológicas e mecânicas, ou seja, a natureza poderá ser dominada pelo Homem e passível de representação por meio de pinturas e xilogravuras. No que diz respeito ao período da Incorporação, a natureza será vista 
como recurso, cuja representação ocorrerá por meio de fotografias e litogravuras. No terceiro e último momento, denominado "O homem e o território", abordar-seá a apropriação da natureza pela sociedade atual, isto é, a produção da natureza inserida no território.

Dando continuidade ao desenrolar dos fios dessa obra, junto de Ítalo Calvino em Tamara de As Cidades Invisíveis, "caminha-se por vários dias entre árvores e pedras. Raramente o olhar se fixa numa coisa, e, quando isso acontece, ela é reconhecida pelo símbolo de alguma outra coisa: a pegada na areia indica a passagem de um tigre; o pântano anuncia um veio de água; a flor de hibisco, o fim do inverno. O resto é mudo e intercambiável - árvores e pedras são apenas aquilo que são" sem a mediação dos homens e mulheres que a animam. Para compreender como a sociedade ocidental se apropriará da natureza, sendo produzida cada vez mais de maneira tecnificada para ser inserida no território e agregar valor de mercado, Wendel Henrique discorrerá na segunda parte de sua obra sobre "A natureza na cidade e sua apropriação pelos empreendimentos imobiliários", subdividida em três capítulos: "A natureza na cidade", "Um bosque para chamar de meu. A apropriação das ideias de natureza pelos empreendimentos imobiliários" e, por fim, "O direito à natureza na cidade". O capítulo "A natureza na cidade", traz como elemento caracterizador da natureza na cidade a vegetação - enclausurada no urbano como um modelo de natureza historicamente construído pela tecnociência-, e por meio de um paralelo histórico-geográfico-cultural, o autor nos brinda com peculiaridades da inserção da natureza em alguns países europeus (França, Inglaterra, Itália e Holanda) e no Brasil para, no capítulo, "A apropriação das ideias de natureza pelos empreendimentos imobiliários", apresentar três capitais brasileiras (São Paulo, Florianópolis e Salvador) como exemplos do uso que os empreendimentos imobiliários fazem da ideia de natureza para agregar valor aos condomínios e outros imóveis, a partir de um ideal harmônico da relação Homem/Natureza. Com muita propriedade o autor (des)naturaliza o discurso de uma natureza natural em prol de uma natureza produzida por homens e mulheres.

Por fim, em "O direito à natureza na cidade", Wendel Henrique nos brinda com reflexões brilhantes e não retóricas articuladas aos capítulos anteriores, em prol do estabelecimento de relações entre o Homem urbano e a natureza na cidade, alicerçadas na presença da natureza para toda a cidade e classes sociais e não somente como fruto de exclusivismos para determinados grupos sociais. A partir disso, o autor elabora dez proposições acerca da produção e uso da natureza nas cidades contemporâneas: 1 . É preciso criar um direito à natureza na cidade, como um direito coletivo; 2. É preciso renovar a liberdade criadora e destruir a ideologia do consumo; 3. É preciso que a natureza na cidade seja para e de todos, independente do poder aquisitivo; 4. É necessário publicizar/desprivatizar a natureza; 5. É 
preciso regatar a ideia de totalidade da natureza na cidade; 6. É necessário entender a natureza na cidade como obra para e pelo homem; 7. É preciso educar/conscientizar os urbanistas para que tratem a natureza nas cidades fazendo-as "cidades verdes"; 8. É preciso instaurar a apropriação da natureza na cidade sob a égide do conceito de valor de uso e não do valor de troca; 9. É preciso coibir a prática atual de que a cidade e a natureza se transformem em bens privados, privatizando-se tradicionais bens públicos; 10. É preciso produzir uma natureza na cidade, entendendo-a como uma natureza humanizada, cuja totalidade torna obsoleta a tradicional dicotomia ente ambiente construído x ambiente "natural". A partir destas proposições, o autor apresenta um "Croqui com a proposta do Parque Urbano da Ponta do Goulart, em Florianópolis (SC)".

Por essa e outras razões este jovem autor estabelece uma perspectiva geográfica original e de vanguarda para a Geografia contemporânea, ao realizar a investigação das ideias e conceitos de natureza, originadas das relações que as sociedades constituíram ao longo da história. Assim, agradeço a ele pela oportunidade de contemplar esta narrativa tão bem cuidada, refletida e utópica.

Valéria Cazetta (EACH-USP)

São Paulo, agosto de 2009. 



\section{APRESENTAÇÃO}

As técnicas, a produção, as indústrias e a cultura possibilitam a incorporação da natureza à vida social. Essa proximidade com a natureza instiga a se pensar cada vez mais seus conteúdos e limites. Este questionamento sobre as relações que os homens estabelecem com a natureza, através das técnicas e da cultura, surgiu em 1999, durante uma disciplina cursada na Unicamp e depois desenvolvida em uma tese de doutorado, orientada pelo Prof. Dr. Pompeu Figueiredo de Carvalho. Esta tese foi defendida junto ao curso de Pós-graduação em Geografia - Área de Concentração em Organização do Espaço (UNESP/Rio Claro), e teve as contribuições das Professoras Doutoras Magda Adelaide Lombardo, Vânia Rúbia Farias Vlach e dos Professores Doutores José Francisco e Paulo Roberto Godoy.

Iniciou-se o desvelamento desta problemática com uma postura epistemológica, construindo e reconstruindo as ideias e os conceitos de natureza, a partir das interpretações de Bachelard (1983) sobre a história do conhecimento e das motivações que levam a busca pelas transformações e produção dos pensamentos e das ideias. Este é o caso dos pensamentos, das ideias e dos conceitos de natureza, que surgiram das relações que as sociedades e os homens constituíram na sua história.

Escrevendo sobre as ideias de natureza no curso da história do pensamento humano, Lenoble (1969), afirma que a "palavra" Natureza está empregada para a definição e designação de uma vasta gama de objetos, ações e processos. A explicitação dos conteúdos da Natureza pode ser aparentemente clara, mas esconde armadilhas epistemológicas, que levam a uma complexificação das definições de Natureza e a proliferação do emprego de termos correlatos como natural, ou sobre a natureza das coisas e dos lugares como sinônimos.

Empregamos a mesma palavra para designar a Natura rerum, o conjunto das coisas que existem, e essa característica que 
particulariza cada uma dessas coisas, 'a sua natureza'; a mesma palavra para definir o estudo do físico, do biólogo ou do químico e essa regra suprema dos costumes a que chamamos o direito natural ou a lei natural; a mesma palavra para recomendar um produto ou um remédio que dizemos 'naturais' e para deixar ao sonho toda a sua liberdade no sentimento da Natureza, a Einfühlung da estética alemã. (LENOBLE, 1969, p.199)

Em função desta proliferação de associações da Natureza com diversos objetos e objetivos e a aparente confusão no emprego de suas definições e conteúdos, principalmente no âmbito da Geografia, passou-se a uma pesquisa sobre as teorias e os conceitos construídos ao longo da história sobre a natureza, em bibliotecas do Brasil (UNESP, USP e UNICAMP) e do exterior (EUA, França e Espanha). Também se buscou amarrar esta construção teórica a uma prática, no caso através do estudo dos empreendimentos imobiliários urbanos, localizados principalmente nas cidades de São Paulo/SP, Florianópolis/SC e Salvador/BA. A apropriação e a produção da natureza têm como objetivo a valorização destes referidos empreendimentos, atrelando-os a uma ideia de natureza "sempre verde e tranquila", isto em alguns casos, em pleno centro da metrópole paulista.

Observa-se o aumento significativo dos empreendimentos imobiliários que usam a "propaganda verde". Constata-se uma proliferação de nomes como: jardim, parque, vila, reserva, bosque, com o agravante do uso de outros idiomas: park, jardin, garden, villagio etc. Desta forma, através de uma visão crítica, se buscou a suplantação dessa ideologia que penetra tais empreendimentos, demonstrando que a natureza na cidade é produto da ação social e histórica do homem, as quais, atualmente, estão repletas das intencionalidades capitalistas. Também há uma preocupação na superação da utilização da natureza como um processo de satisfação individual, vinculado ao consumismo, através da construção de um processo de ação e uso da natureza como uma forma de emancipação coletiva, constituindo no mundo contemporâneo, um direito à natureza na cidade para todos os seus habitantes.

Cabe, neste momento, fazer uma consideração importante: na busca pela história da produção de ideias e conceitos de natureza, procurou-se limitar a abordagem na contribuição da Geografia para esta temática. Mesmo com este campo de atuação delimitado em uma disciplina, buscaram-se outras leituras complementares em diferentes campos do conhecimento, principalmente na Filosofia. Entretanto, estas leituras foram feitas tendo um olhar e interpretação geográfica, pois a proposta, desde o início, não foi a realização de uma filosofia da natureza. O que se pretende é uma interpretação geográfica das ideias e conceitos de natureza produzidos ao longo da história humana, visando à dissipação da ideologia que dificulta 
a compreensão do processo de apropriação destas ideias nos empreendimentos imobiliários urbanos no momento histórico atual.

Salienta-se que este trabalho não é uma busca pela definição do que é natureza, como um conceito fechado, mas sim uma busca pelos conteúdos que preenchem as ideias e conceitos sobre a mesma, tanto ao longo da história como em nossos dias. Em todos os períodos da história da humanidade, a forma de relações, quer seja entre a natureza e o homem, entre o homem e a natureza ou entre o homem e o território (aí inserida a natureza), tem vínculos com as ideias e práticas que se estabelecem. O que se apresenta aqui é uma das possibilidades encontradas ao longo do trabalho.

Para compreender melhor todos esses processos envolvendo a Natureza, a Cidade e os Empreendimentos Imobiliários, dividiu-se este livro em duas partes. A primeira parte relativa ao estudo epistemológico e a periodização das ideias e conceitos de natureza. A segunda parte, relacionada à especificidade da natureza na cidade e sua apropriação pelos empreendimentos imobiliários.

Iniciamos no capítulo I, A Cidade e a Natureza, com um panorama das relações entre a cidade e a natureza, tomadas principalmente a partir da ideologia do consumo presente no mundo contemporâneo.

No capítulo II, Uma Periodização para Compreender as Relações entre a Cidade e a Natureza, constitui-se no embasamento metodológico da pesquisa elaborada e apresenta uma proposta de periodização das ideias de natureza para o mundo ocidental.

O capítulo III, A Natureza e o Homem, marca um primeiro período em que as condições colocadas pela natureza eram mais fortes que a ação do homem. Dentro deste período, encontram-se duas divisões: um Período Clássico e um Período Teológico, onde as fontes de informações foram, respectivamente, os Filósofos Estóicos e a Bíblia.

No capítulo IV, O Homem e a Natureza, assinala-se a mudança na posição do homem frente à natureza, quando os homens passam a superar os condicionamentos impostos pela natureza. Nesse momento das relações entre o Homem e a Natureza, define-se dois períodos: um denominado como Período dos Descobrimentos e o outro como Período da Incorporação. A bibliografia chave para entendimentos destes períodos é composta por obras de Francis Bacon, Emmanuel Kant, Conde Buffon, Karl Marx, Friedrich Engels, George Marsh e Élisée Reclus.

O capítulo V, O Homem e o Território, trata da apropriação da natureza pela sociedade atual. A natureza é incorporada ao território, passando a ser um elemento do espaço produzido e usado. Define-se este período como Período da Produção [da Natureza] e as referências fundamentais são Milton Santos e David Harvey. 
A segunda parte do livro se inicia no capítulo VI, A Cidade e a Natureza, no qual é abordado a aproximação entre a cidade e a natureza na história do urbanismo e também a mercantilização da natureza na cidade no período atual.

O capítulo VII, Um bosque para chamar de meu. A apropriação da natureza pelos empreendimentos imobiliários urbanos, focaliza alguns estudos de caso que foram observados nas cidades de São Paulo/SP, Florianópolis/SC e Salvador/BA.

As proposições e as sínteses da base teórica do trabalho aos estudos de caso, se constituem no conteúdo do capítulo denominado O Direito à Natureza na Cidade. Da (des)ideologização da prática para a consciência crítica da praxis na relação com a natureza. Nesse capítulo, se recupera a ideia da extensão da natureza a toda cidade e não seu enclausuramento nos condomínios de alto padrão, através de dez proposições e de formas de utilização coletiva da natureza na cidade.

No processo de elaboração da tese, o auxílio da CAPES, através de uma bolsa de Doutorado, permitiu a dedicação completa à pesquisa. A partir de agosto de 2008, para aprofundamento da temática deste livro para Salvador e Região Metropolitana, deve-se agradecer aos recursos financeiros recebidos do $\mathrm{CNPq}$, a partir de projeto de pesquisa aprovado no Edital de Ciências Humanas e Sociais aplicadas, bem como as bolsas de Iniciação Científica da FAPESB, no período 2007/2008. 


\title{
I - A CIDADE E A NATUREZA
}

\begin{abstract}
A pedra, a planta, o animal são, quando começam a existir, o que eles podem ser, não o que eles podem vir a ser. O Homem, por outro lado, não tem, no início de sua existência, nenhuma imagem prefixada ou imposta, mas pelo contrário, carrega consigo - predeterminada e imposta - a liberdade para escolher o que será. E isto, dentro de um vasto horizonte de possibilidades. O poder de escolher, o que no universo do ser é seu privilégio, tem ao mesmo tempo a natureza de uma sentença e um trágico destino, pois ele é forçado a selecionar a sua própria maneira de ser e também é condenado à responsabilidade por ser ele mesmo - uma situação pela qual não passa a pedra, a planta ou o animal ${ }^{1}$.
\end{abstract}

Ortega y Gasset, 1973

A cidade, grande realização humana, artefato por excelência e aparente negação da natureza, torna-se o local principal para observação de uma nova relação, mitológica, capitalista e midiática, do homem com a natureza. A natureza, metáfora ou metonímia, que já havia sido reificada e incorporada à vida social, ao longo da história do homem, é apropriada e até mesmo produzida, com o objetivo de valorização monetária de objetos/mercadorias nos mais variados segmentos da produção e dos serviços.

O geógrafo americano Neil Smith (1984), escrevendo sobre o aparente "absurdo" de uma ideia da produção da natureza pelo homem, afirma que, a partir do avanço técnico, tecnológico e da acumulação do capital criaram-se possibilidades concretas da produção da natureza. O que anteriormente era visto como algo oposto à criação humana, agora pode ser fruto da produção social. Partilha-se, deste modo, da ideia de Smith, da produção da natureza pela sociedade no momento histórico atual e da necessidade de se renovar às ideias e conceitos de natureza. 
A natureza, material e simbolicamente, incorpora-se à esfera de um mundo capitalista, de uma racionalidade instrumental e da criação de um conjunto de necessidades que parecem ser naturais ao homem, mas que se constituem apenas em mais possibilidades de consumo ${ }^{2}$. Marx (1962, p.144), criticando a transformação da natureza em mercadoria e sua apropriação pelos capitalistas, escreve que "todo produto é uma isca por meio da qual o indivíduo tenta apanhar a essência da outra pessoa, o dinheiro dela”.

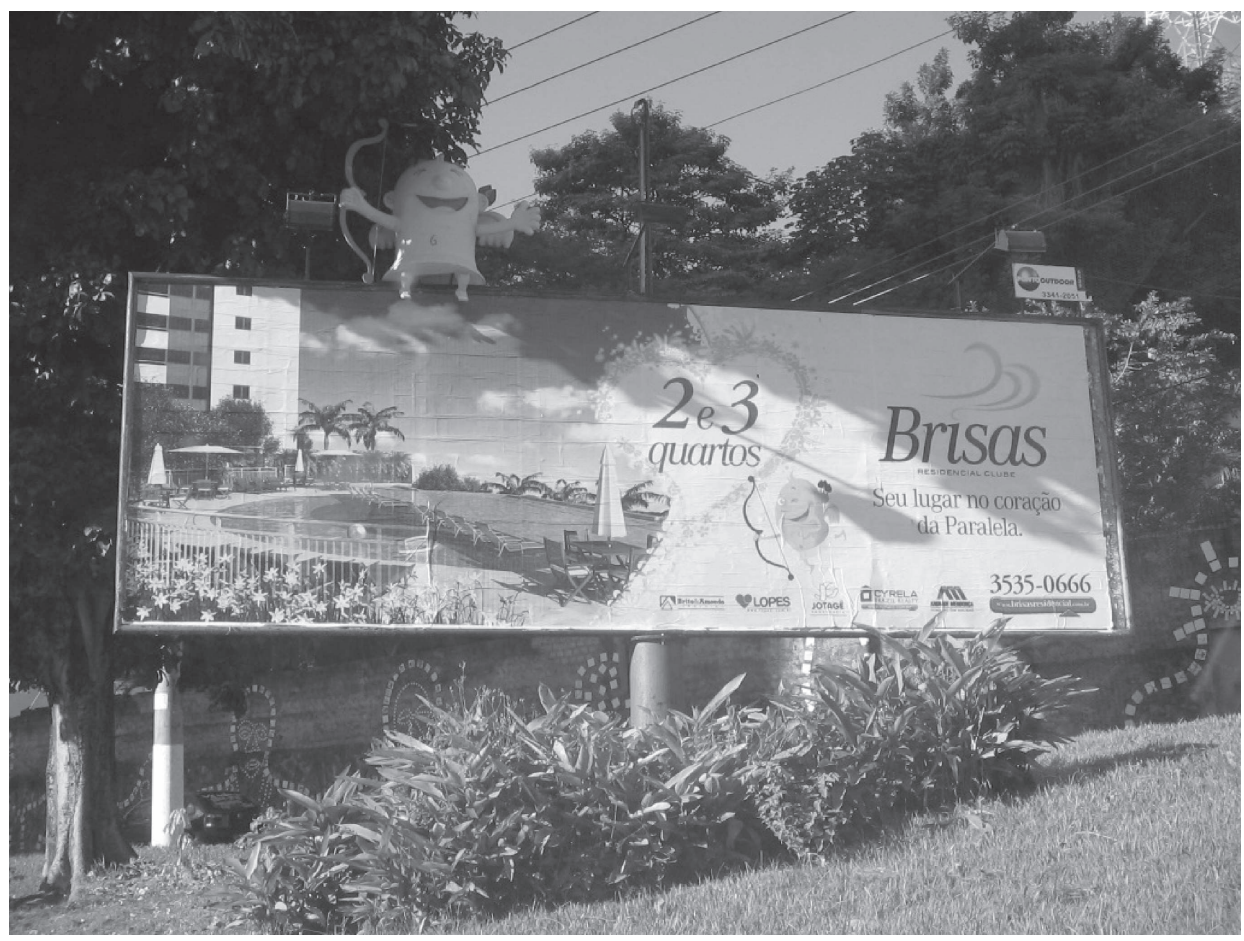

Propaganda em via pública de empreendimento em Salvador. Nota-se o uso de um elemento da natureza no nome do empreendimento, bem como de figuras mitológicas para "flechar" o coração do comprador.

A natureza, como parte do espaço geográfico, como elemento do território usado, é incorporada e produzida na forma de objetos e ideias. É transformada em recurso pela valorização do espaço e um intenso uso do território. Esse denso e utilizável espaço geográfico, conectando Homem e Natureza, Técnicas e Cultura pode resultar em mentiras funcionais, definidas e criticadas por Santos (1982, p. 25), pois toda a natureza congelada no senso comum como paisagem, tende a ser transformada em cartões postais e em fetiche. 
Esta natureza artificial, resultante da produção social da natureza, da ação humana, além de ser apropriada de maneira privada, negando o caráter social da sua produção, encontra-se "falsificada" e "descolada" das características naturais dos lugares. No mundo contemporâneo, a natureza produzida pode se tornar uma ficção ou uma "mentira", sem vínculos com uma identidade geográfica local. A natureza padronizada se encontra hoje compromissada com uma felicidade capitalista ${ }^{3}$. Uma natureza carregada de ideologia que não mostra toda a história da sua construção social, uma natureza ideologizada que busca apagar as diferenças entre classes, fornecendo um "sentimento da identidade social" a partir de referências coletivas, como explica Chauí (1984).

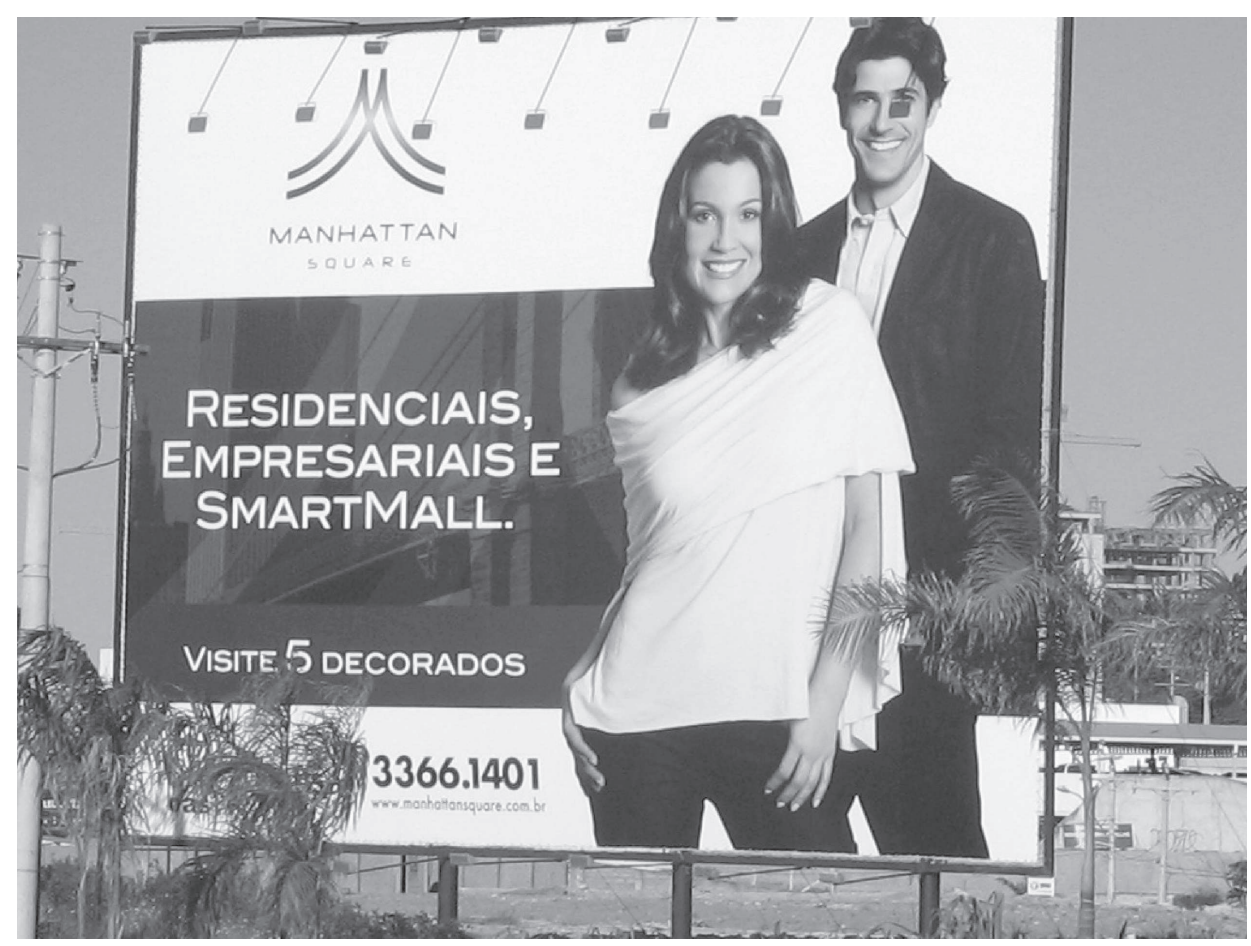

Propaganda em via pública de empreendimento em Salvador. Destaca-se o uso de expressões estrangeiras na propaganda.

Hoje, a natureza, ideia e objeto, capitalizada e mercantilizada, tem seus consumidores e clientes, pessoas que por ela transitam, passam, viajam, comprando-a e consumindo-a, literal ou metaforicamente falando, como símbolo, imagem, ícone, poder ou status. 
A natureza também pode ser usada como forma de contingenciamento ou separação de grupos e classes sociais, barrando os acessos e os contatos entre bairros de rendas distintas, por exemplo. A demanda pela proteção da natureza, bem como a busca pela proximidade com a natureza nas cidades, tornou-se onipresente em todos os planos de governos, planos diretores e outros instrumentos de planejamento. A sua concretização ocorre através de reservas, florestas nacionais, praças, jardins e parques públicos. É praticamente impossível encontrar uma pessoa ou grupo que se posicione contrariamente a construção de uma praça ou com a manutenção de uma grande área verde em um espaço altamente adensado de uma cidade.

Entretanto, muitas destas ações "inofensivas", se analisadas isoladamente, podem esconder grandes intencionalidades perversas. A natureza serve para separar e segregar grupos sociais indesejados a uma determinada parcela da sociedade, ou a um nicho de mercado de atuação de empresas do ramo imobiliário. Dois bairros de rendas e valores dos imóveis bem distintos podem ser separados por um parque. Como a natureza é preservada e a sociedade encontra-se mobilizada contra os "crimes ambientais" (basta notar a comoção mundial em prol do ursinho polar Knut, "abandonado" pela mãe em um zoológico da Alemanha) este parque será a possibilidade real - física e geográfica - de manutenção da separação entre estes dois bairros, impossibilitando a aproximação das áreas de ocupação. Servirá como uma "cerca" ou "muro" verde entre as áreas.

Para completar este uso perverso da natureza, na cidade, muitas áreas que servem para barrar o acesso de grupos indesejados, bem como para impossibilitar a ocupação e aproximação de classes de rendas distintas, são construídas e mantidas com recursos públicos e, em prol da "qualidade ambiental", estas áreas verdes são cercadas e protegidas com muros, cercas e câmeras de vigilância, tendo seu acesso controlado e restrito, se configurando em mais um dos casos de produção social da natureza, mas com a apropriação privada e exclusiva de um determinado grupo ou segmento de renda.

Nas grandes cidades, lugares altamente tecnificados e artificializados, frutos da ação humana, a presença de uma natureza natural encontra-se muito distante, tornando-se necessário, desta forma, a produção de um sistema de ideias e símbolos que tragam a imagem de uma natureza natural para a cidade e, até mesmo, que se produza uma natureza padronizada e adequada aos padrões urbanos. Além disso, a natureza material, efetivamente incorporada e produzida, enclausurada nas propriedades imobiliárias privadas, terá seu acesso definido de maneira desigual, entre, por exemplo, os condomínios de alto padrão e os conjuntos habitacionais de baixa renda. 

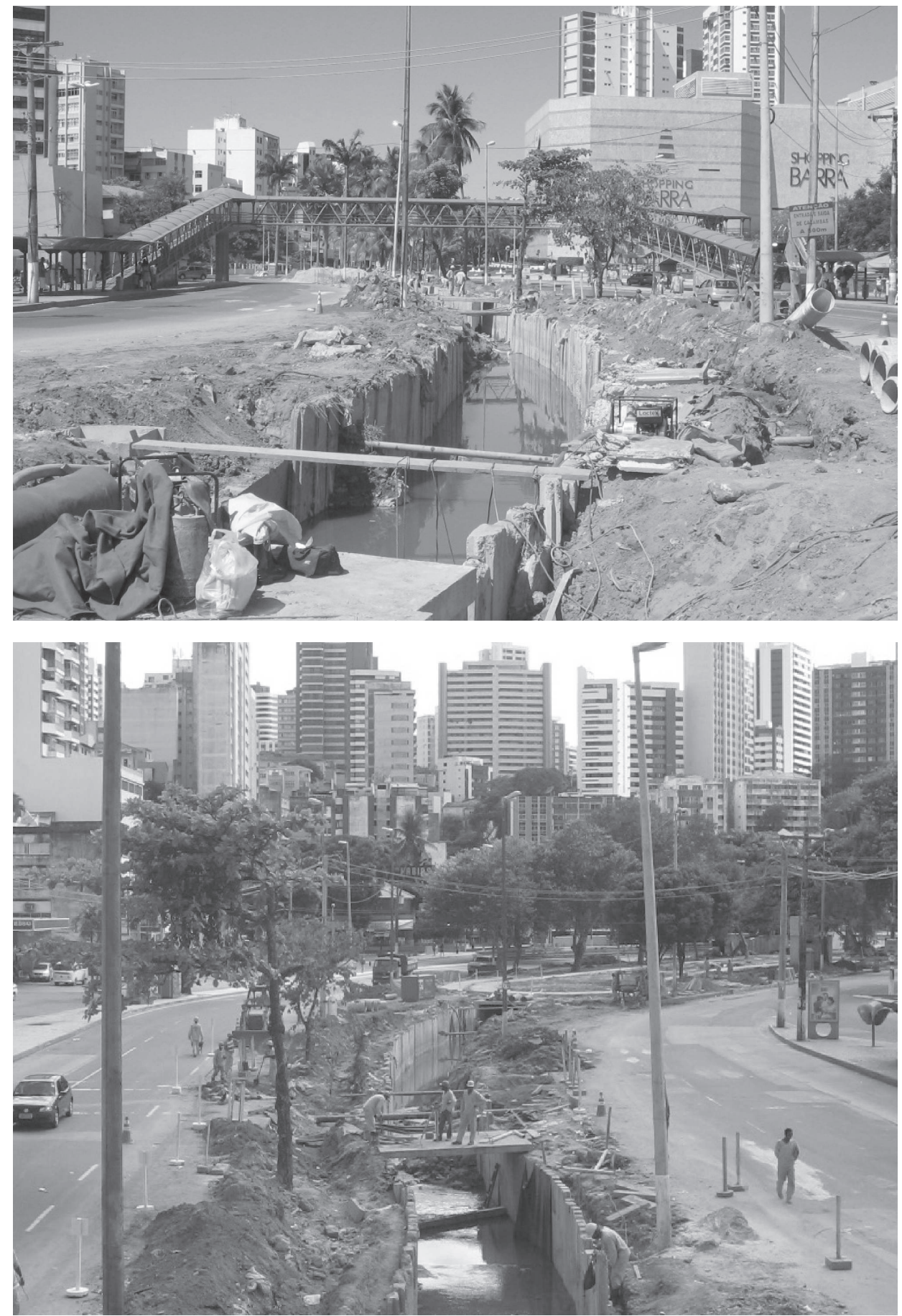

Canalização do Rio dos Seixos (Avenida Centenário) em Salvador (ago/2008). Apesar do discurso sobre a natureza na cidade, elementos naturais não desejáveis são escondidos. 
$\mathrm{Na}$ maioria das cidades, apesar do apelo estético e econômico sobre a presença da Natureza, constata-se que apenas alguns elementos naturais são valorizados, como a vegetação (transformado em área verde). Ainda assistimos a grandes obras que aterram ou canalizam córregos e rios.

O cotidiano nas cidades, principalmente nos condomínios atrelados a uma ideia de natureza, aparece como uma história de crianças - é a materialização da felicidade num endereço. Estabelece-se uma vinculação da felicidade ao consumo e ao valor de troca adquirido pela propriedade privada. Esta associação acaba por gerar a formulação de ações de planejamento urbano, nas esferas públicas e/ou privadas, bem como em diversas escalas, atreladas à busca de uma feliz cidade sem conflitos, esteticamente aprazível e carregada de verde, mesmo que apenas simbolicamente, capaz de suprir, por si mesma, as necessidades intrínsecas aos homens e cumprir seus papeis na satisfação dos desejos criados na contemporaneidade, principalmente, pelo consumo.

No consumo imobiliário e na produção da cidade e da natureza, observa-se hoje um urbanismo preocupado com o mercado imobiliário. Segundo Lefebvre (1969, p. 28), "o projeto dos promotores de venda se apresenta como ocasião e local

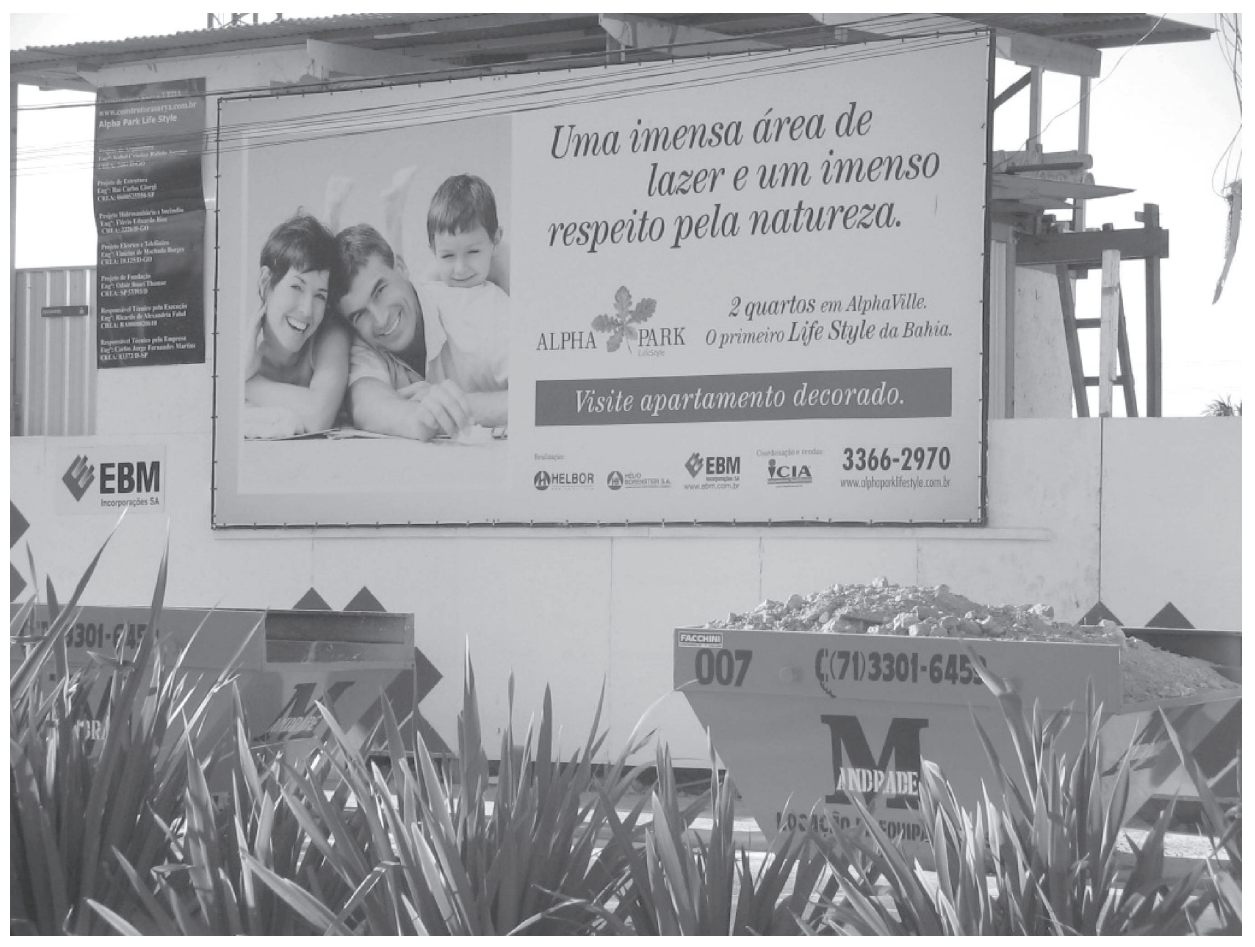

Propaganda em via pública de empreendimentos em Salvador.

A vinculação entre o empreendimento e a natureza é clara. 


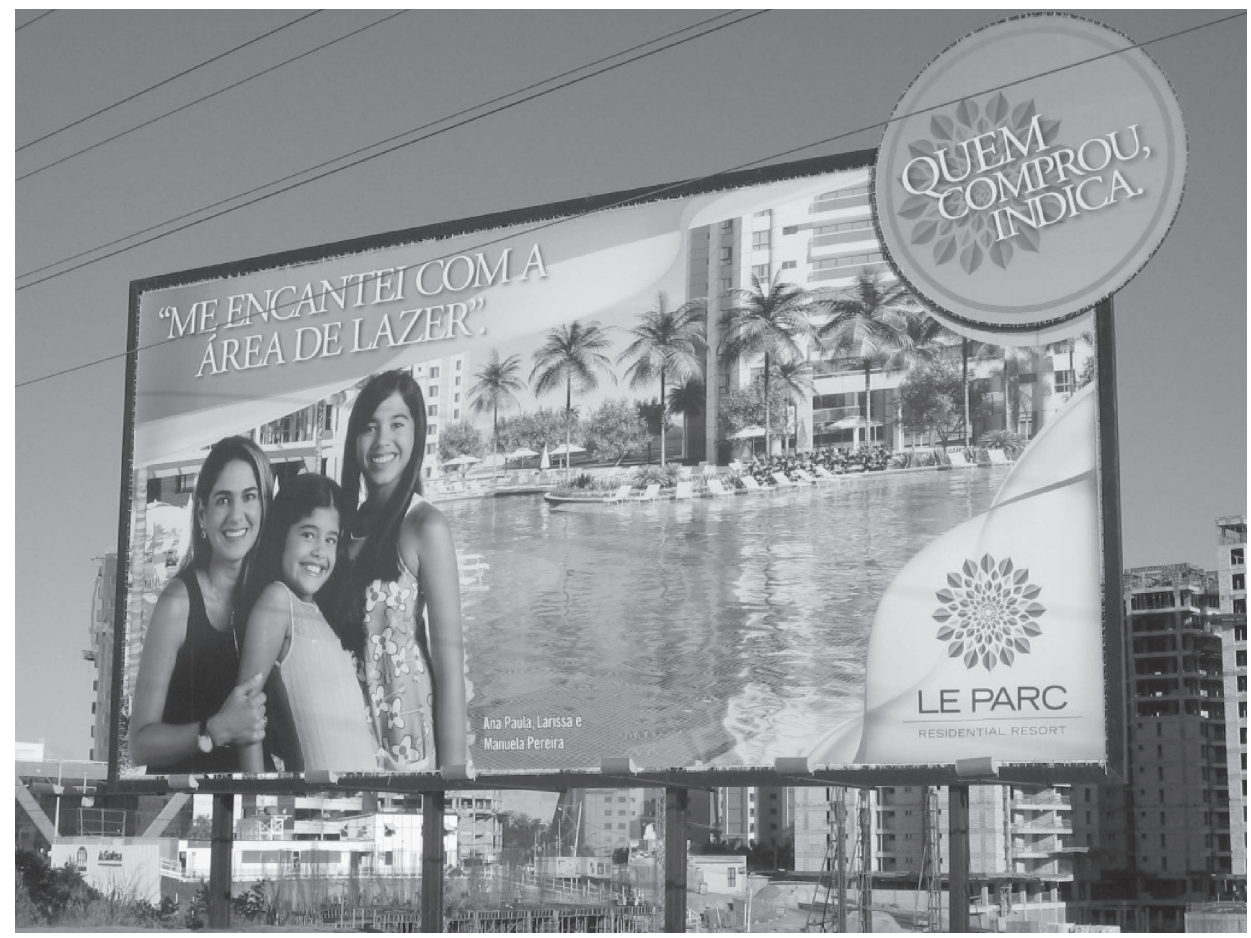

Propaganda em via pública de empreendimentos em Salvador. Esta propaganda associa-se a ideia de felicidade, na aquisição do imóvel e de seus exclusivos elementos, a natureza e a área de lazer.

privilegiado: lugar da felicidade numa vida quotidiana miraculosamente e maravilhosamente transformada".

Esta ação humana sobre a natureza irá internalizar as contradições entre os projetos de emancipação coletiva e de satisfação pessoal. A Emancipação pressupõe a Cooperação e a Satisfação implica na Competição entre os homens e entre estes e a natureza, ou o território. Uma das questões centrais na relação entre emancipação e satisfação é a constatação, no período atual, da ascensão da realização pessoal para se entender o valor da natureza. Este valor, presente na realização da satisfação pessoal, se materializa no uso e na incorporação das "palavras", exclusivo, privilégio e privativo nas propagandas imobiliárias, no tocante a relação com a natureza.

Como contraponto, se pode, a partir da ideia de "apropriação justa" desenvolvida por Harvey (1973), pensar uma apropriação da natureza dentro de um projeto de emancipação coletiva. Desta forma, não deve ser caracterizada como uma forma de exploração, uma vez que, o que é apropriado, a natureza, é posto para o benefício coletivo. 


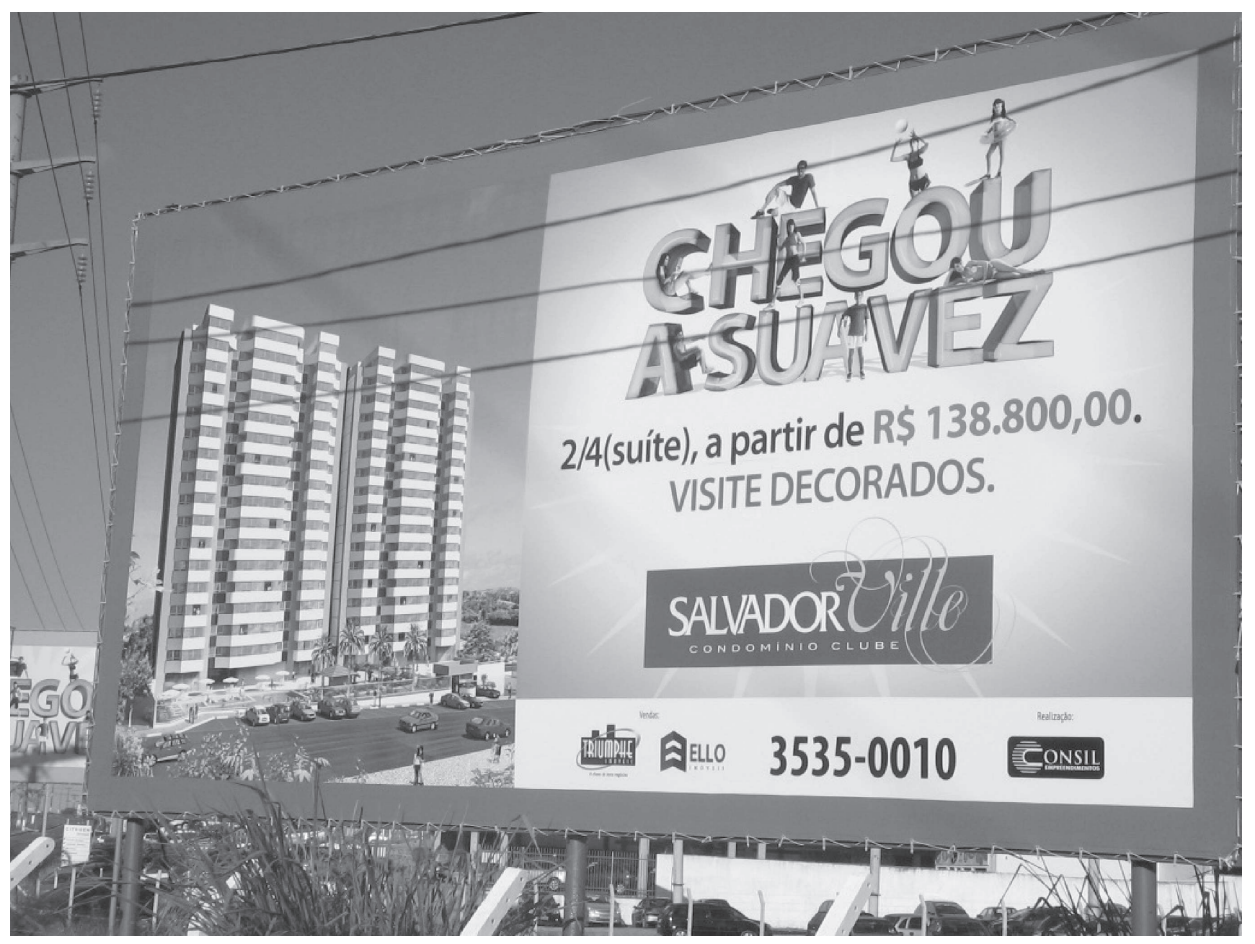

Propaganda em via pública de empreendimento em Salvador. Um exemplo entre muitos que buscam o indivíduo, sendo que muitos empreendimentos passam a colocar termos como "Exclusive" e "Privilege" em seus nomes.

A apropriação de ideias de natureza pelos empreendimentos imobiliários e a substituição de um projeto de emancipação coletiva pela satisfação individual são pura ideologia ${ }^{4}$. O papel da ideologia, nesta relação entre cidade e natureza, observada nos empreendimentos imobiliários, é a negação de todas as conquistas dos homens perante a natureza, é um retorno a uma natureza romântica e primitiva, mas que esconde sob estas ilusões uma natureza altamente tecnificada e acrescida de instrumentos técnicos para propiciar o conforto na vida individual e acesso restrito, definido pela renda.

Outro ponto a ser observado, é que as propagandas dos empreendimentos imobiliários "apagam" a cidade real, criando uma imagem do local do empreendimento repleta de áreas verdes, de árvores, de espaço, mas que se apresenta apenas como um cenário irreal, pois estes empreendimentos se encontram em áreas altamente adensadas, onde espaço livre e área verde não são mais disponíveis. 


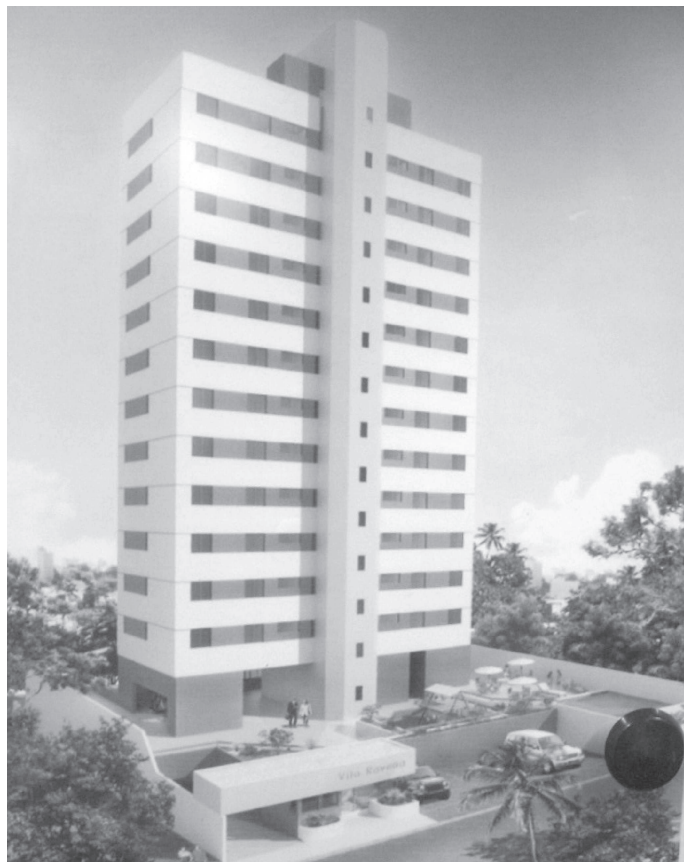

Propaganda em área pública de empreendimento em Salvador. Na representação observa-se que o empreendimento está rodeado de áreas verdes e espaços livres.

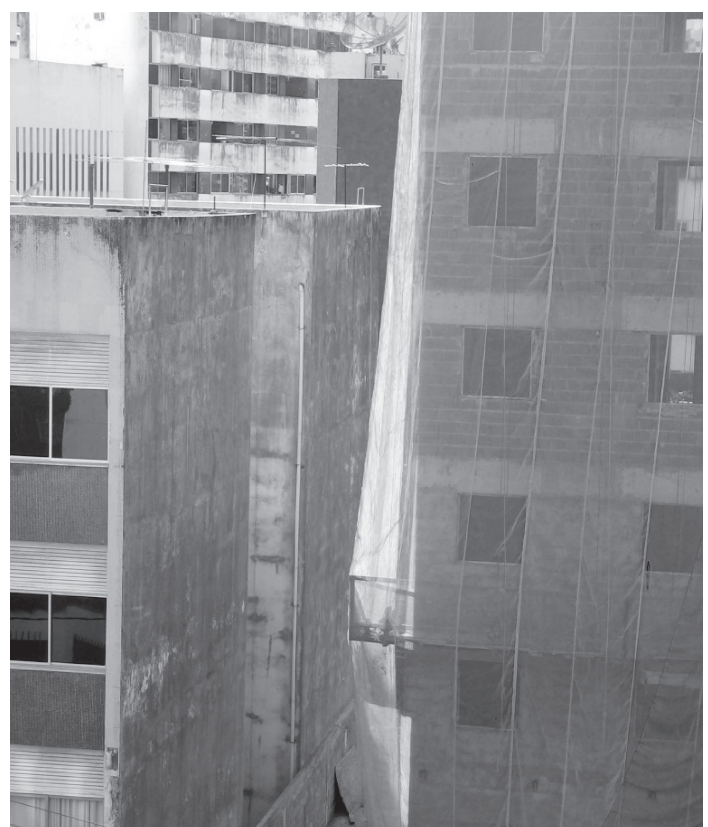

Fotografias realizadas em setembro de 2008, o local do empreendimento, demonstrando a inserção real do empreendimento na cidade e a ausência de áreas verdes (ago./2008) 

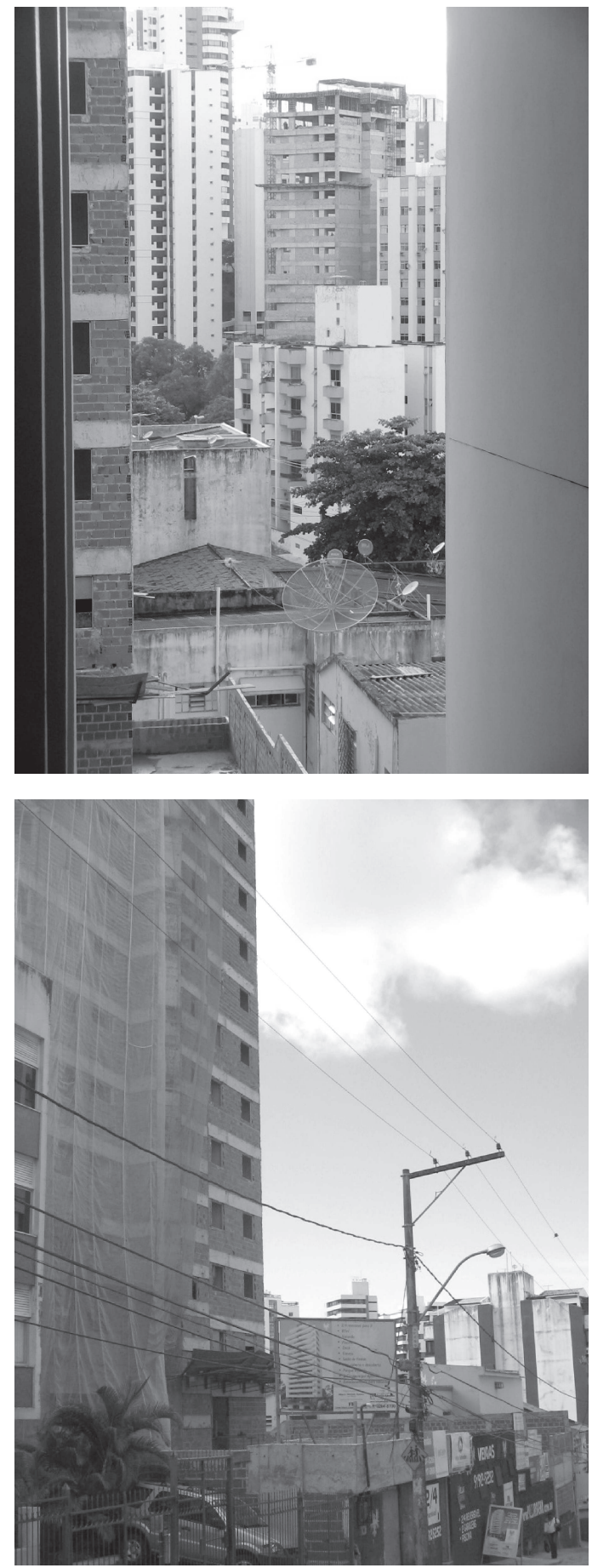

Fotografias realizadas em setembro de 2008, o local do empreendimento, demonstrando a inserção real do empreendimento na cidade e a ausência de áreas verdes (ago./2008) 
Perante esta profusão de usos, apropriações e representações da natureza na cidade contemporânea, tornou-se fundamental e necessário resgatar a história das relações entre a sociedade e a natureza, os sistemas de ideias e conceitos elaborados ao longo do tempo, para esclarecer a história que a ideologia capitalista urbana tende a esconder e mascarar as propagandas e construções dos empreendimentos imobiliários. Partiu-se de uma busca por uma história das ideias e conceitos de natureza ${ }^{5}$, para se resgatar o processo de transformação, incorporação e produção da natureza pelo homem. Esta busca se configura no alicerce teórico-conceitual para desvelar a natureza encontrada, física ou simbolicamente, nas cidades.

\title{
NOTAS
}

\begin{abstract}
${ }^{1}$ Neste trabalho, as citações em língua estrangeira foram traduzidas pelo autor no corpo do texto e o original aparece na íntegra e no idioma original nas notas. "The stone, the plant, the animal are, when they begin, whatever they can be, and therefore what they are going to be. Man, on the other hand, has when he begins to exist, no prefixed or imposed image of what he is going to be, but, on the contrary, he carries with him - predetermined and imposed - the freedom to choose what he is going to be. And this within a wide horizon of possibilities. The power to choose, which, in the universe of being is his privilege, has at the same time the Nature of a sentence and a tragic destiny, for as he is forced to select his own manner of being he is also condemned to the responsibility for being himself - a situation which does not confront the stone, the plant, or the animal." (ORTEGA Y GASSET, 1973, p. 12)

${ }^{2}$ Para Marx (1962, p. 60-61), "no mundo alienado do capitalismo as necessidades não são manifestações de poderes latentes do homem, isto é, elas não são necessidades humanas; no capitalismo, cada homem especula sobre como criar uma nova necessidade em outro homem a fim de forçá-lo a um novo sacrifício, colocá-lo em uma nova dependência, e incitá-lo a um novo tipo de prazer e, por conseguinte, à ruína econômica. Todos tentam estabelecer sobre os outros um poder estranho para com isto lograr a satisfação de sua necessidade egoísta".
\end{abstract}

3 Segundo Lefebvre (1969, p. 62) 'torna-se assim, a ideologia desta sociedade, cada 'objeto', cada 'bem' se desdobra numa realidade e numa imagem, fazendo, esta, parte essencial do consumo. Consomemse tantos signos quanto objetos: signos da felicidade, da satisfação, do poder, da riqueza, da ciência, da técnica etc. A produção desses signos se integra na produção global e desempenha um papel integrador fundamental em relação às outras atividades sociais produtivas ou organizadoras. O signo é comprado e vendido; a linguagem torna-se valor de troca".

${ }^{4}$ O conceito de ideologia é aqui empregado a partir da leitura de Chauí (1984, p. 120), quando escreve que "a ideologia fabrica uma história imaginária (aquela que reduz o passado e o futuro às coordenadas do presente), na medida em que atribui o movimento da história a agentes ou sujeitos que não podem realizá-lo". Outras abordagens do conceito de ideologia podem ser encontradas nas obras de Antonio Carlos Robert de Moraes, Michel Löwy e Lênin. 
${ }^{5}$ Ortega y Gasset (1973) explica as maneiras para que se penetre em algum assunto, ideia ou conceito, através do exemplo de uma folha. Se o objetivo é saber o que vem a ser uma folha, irá rapidamente se notar que a ideia prévia sobre a folha não coincide com a folha real, pela simples razão que não se pode determinar onde a coisa que está se chamando de folha termina e onde outra coisa começa. Descobre-se que a folha não termina em si mesma, mas continua no ramo e o ramo por sua vez continua no caule e o caule nas raízes. A folha, então, não é em si mesma uma realidade que pode ser isolada do resto. Seguindo estas considerações, não se busca apenas fazer uma lista das ideias e conceitos de natureza, mas sim ligá-las ao conjunto do movimento da história do homem, com uma visão geográfica. Deve-se aprofundar a partir de uma simples palavra ou conceito, e penetrar no seu sistema de relações, tentando dar um significado com o menor grau de ambiguidade. 


\section{II - UMA PERIODIZAÇÃO PARA COMPRENDER AS RELAÇÕES ENTRE A CIDADE E A NATUREZA}

Este capítulo se configura como um esforço metodológico, a partir de uma concepção de método, que busca a sistematização de procedimentos de análise e de interpretações que dêem conta do arcabouço teórico-conceitual das relações estabelecidas ao longo da história da humanidade entre a cidade (sociedade) e natureza, do ponto de vista simbólico das representações e da própria ação social, através das técnicas, na produção do espaço e nos usos do território.

De acordo com Kosik (1976, p. 10),

no trato prático-utilitário com as coisas - em que a realidade se revela como mundo dos meios, fins, instrumentos, exigências e esforços para satisfazer estas - o indivíduo 'em situação' cria suas próprias representações das coisas e elabora todo um sistema correlativo de noções que capta e fixa o aspecto fenomênico da realidade.

Como metodologia de pesquisa neste trabalho, recorreu-se a elaboração de uma periodização ${ }^{6}$. Santos (1997, p. 23), define um período como

secções de tempo em que, comandado por uma variável significativa, um conjunto de variáveis mantém um certo equilíbrio, uma forma de relações. Cada período representa, no centro do sistema, um conjunto coerente de formas de ação.

A divisão da história em períodos não é um fato, mas uma hipótese necessária ou uma ferramenta para o pensamento, válida até como uma forma de esclarecimento, tendo sua validade dependente da sua interpretação. 
[...] empiricizamos o tempo, tornando-o material e, desse modo, o assimilamos ao espaço, que não existe sem materialidade. A técnica entra aqui com um traço de união, historicamente e epistemologicamente. As técnicas, de um lado, dão-nos a possibilidade de empiricização do tempo e, de outro lado, a possibilidade de uma quantificação precisa da materialidade sobre a qual as sociedades humanas trabalham. (SANTOS, 1999, p.44)

A respeito da materialidade do espaço geográfico, passível de periodização, Souza (1994) afirma que

\begin{abstract}
a geografia deve sempre se referir a realidades concretas. O texto e o contexto geográficos apresentam materialidades. A geografia trata da evidência do real-concreto, que é histórico, e tem sempre um lugar (sítio e situação) no espaço geográfico. Neste sentido, a teoria geográfica implica necessariamente uma referência empírica. Esta é, indiscutivelmente, um instrumental metodológico essencial da geografia. As abstrações, embora consideradas geográficas, carecem de referencial empírico (histórico), do qual se vale a geografia para explicar seu objeto - o espaço geográfico, que é também histórico [...] O teóricoempírico é atributo do método geográfico.
\end{abstract}

Assim, para Souza (1994, p.48), um período é entendido como "etapa ou momento do modo de produção, muito bem expresso pelas formações sociais, as quais sempre realizam, num dado lugar, a combinação de ideias e momentos distintos". Uma periodização é uma possibilidade dada para o recorte metodológico do tempo, uma quebra da totalidade temporal em períodos, sem a perda das determinações/relações com a totalidade.

É preciso considerar os elementos dentro do sistema temporal ao qual pertencem, evitando apenas o elencar de datas históricas sem, contudo, chegar-se ao cerne do sistema temporal, que é a noção de totalidade ou conjunto de situações geográficas e históricas.

A sustentação de um período é dada pela organização e relações entre variáveis ao longo de uma seção temporal, onde as variáveis assumem graus múltiplos de relevância. A organização destas variáveis é que produzem um período e mantém suas características gerais, apesar do contínuo movimento da sociedade. Quando a organização se esgarça, o período finda e se inicia um novo período. O processo de ruptura de um período para outro é dado pela introdução de uma nova variável - técnica ou cultural. 
O grande trunfo da periodização é a possibilidade metodológica de empiricizar em conjunto o tempo e o espaço (objetos e ações). A periodização permite apreender, a cada momento histórico, os conteúdos e os valores atribuídos pela sociedade e que qualificam a natureza e o espaço geográfico (cidade). Além disto, de acordo com Santos (1988, p.83),

um método assim elaborado e sistematicamente aplicado nos permitirá entrever igualmente as novas tendências do uso do território. [...] Essa noção de periodização é fundamental, porque nos permite definir e redefinir conceitos e, ao mesmo tempo, autoriza a empiricização do tempo e do espaço, em conjunto.

Para Sartre (1968, p.30), "os fatos particulares nada significam, não são verdadeiros nem falsos enquanto não forem referidos pela mediação de diferentes totalidades parciais à totalização em curso". Sem o uso social da técnica, esta se resume a um mero artefato. O mesmo pode-se aplicar à Natureza, que separada, isolada, retirada do mundo social, perde todo o seu significado histórico, geográfico e social.

\section{UMA PROPOSTA}

Atrelada ao método e a metodologia desenvolvida, elaborou-se uma periodização sobre as ideias e conceitos de natureza, que se configurou em uma construção epistemológica e base teórica para o entendimento da apropriação e das relações entre a cidade e a natureza pelos empreendimentos imobiliários urbanos. A proposta tem como meta superar a história 'ilusória' que a ideologia insere nesta apropriação, conforme destacado anteriormente.

As fontes de informações para elaboração da referida periodização foram de referências bibliográficas da área de Filosofia da Natureza e Geografia. Salienta-se que esta proposta de periodização está restrita as ideias do mundo ocidental, não sendo detalhadas as contribuições do mundo oriental, islâmico ou pré-colombiano.

No primeiro período, o conhecimento sobre a Natureza era fruto da imaginação e contemplação, e ocorria através dos relatos heróicos dos "aventureiros". Atrelava-se a ideia de natureza à concepção de um mito. No âmbito das cidades, estas ainda eram incipientes, sendo representadas pela cidade grega. O objeto fonte de interpretação será a própria natureza. O marco cultural do período na questão da 
interpretação da natureza é a contribuição da cultura helênica, com suas histórias e épicos. Os gregos também apresentaram importantes contribuições científicas para o entendimento da natureza, não negando as contribuições dos egípcios, mesopotâmios e romanos. A principal ação do homem sobre a natureza é dada pela invenção e propagação das técnicas da irrigação, que permitiram o maior desenvolvimento da agricultura e, consequentemente, propiciaram o incremento da produção de alimentos.

Quadro 01 - Esquema da periodização das ideias e conceitos de natureza para o mundo ocidental - uma tentativa

\begin{tabular}{|c|c|c|c|c|c|c|c|}
\hline Momento & História & Período & $\begin{array}{l}\text { Concepção } \\
\text { de natureza }\end{array}$ & $\begin{array}{c}\text { Representação } \\
\text { da Natureza }\end{array}$ & $\begin{array}{l}\text { Recursos } \\
\text { Técnicos }\end{array}$ & Cultura & $\begin{array}{c}\text { Aspecto } \\
\text { dominante } \\
\text { da relação } \\
\text { homem- } \\
\text { natureza }\end{array}$ \\
\hline \multirow{2}{*}{$\begin{array}{l}\text { A Natureza } \\
\text { e o Homem }\end{array}$} & Idade Antiga & Clássico & Mito & Literatura & Irrigação & Helênica & Contemplação \\
\hline & Idade Média & Teológico & Divina & Bíblia & Arado & teológica & Temor \\
\hline \multirow{2}{*}{$\begin{array}{l}\text { O Homem e } \\
\text { a Natureza }\end{array}$} & Idade Moderna & Descobrimentos & Fisicoteológica & $\begin{array}{c}\text { Pintura } \\
\text { Xilogravuras }\end{array}$ & $\begin{array}{c}\text { Caravela } \\
\text { Balão }\end{array}$ & $\begin{array}{c}\text { Marítima- } \\
\text { comercial } \\
\text { rural }\end{array}$ & Dominação \\
\hline & \begin{tabular}{c|} 
Idade \\
Contemporânea
\end{tabular} & Incorporação & $\begin{array}{l}\text { Mecânica } \\
\text { Recurso }\end{array}$ & $\begin{array}{c}\text { Fotografia } \\
\text { Litogravura }\end{array}$ & $\begin{array}{l}\text { Automóvel } \\
\text { Avião }\end{array}$ & Industrial & Incorporação \\
\hline $\begin{array}{l}\text { O Homem e } \\
\text { o Território }\end{array}$ & $\begin{array}{c}\text { Idade } \\
\text { Contemporânea }\end{array}$ & Produção & Artifício & $\begin{array}{l}\text { Imagem } \\
\text { Orbital }\end{array}$ & Satélite & Urbana & Produção \\
\hline
\end{tabular}

Organização e Elaboração: Henrique, 2004

O segundo período vai ser marcado pela interpretação da Bíblia, objeto fonte do entendimento da natureza, denotando uma forte componente teológica da natureza. No âmbito das técnicas, o arado foi a grande revolução encontrada e, juntamente com a irrigação, aumentou a produção agrícola no período. Mesmo com este aparente desenvolvimento técnico, o temor à vontade de Deus irá prevalecer e a natureza, entendida como Sua obra, será dotada de valor divino. O mundo citadino será caracterizado pelas cidades feudais, protegidas pelas fortes muralhas e, desta forma, separada fisicamente da "natureza" - dos bosques, florestas etc.

A superação dos obstáculos físicos e intelectuais no entendimento da natureza se processou no terceiro período. As constantes viagens marítimas e comerciais ao longo do mundo conhecido e a descoberta de novas terras recuperaram e desenvolveram outros objetos para a compreensão/representação da natureza, como as pinturas e as xilogravuras, estas últimas difundidas com o advento da 
imprensa. As técnicas atreladas aos transportes, como a caravela e o balão, ampliaram o horizonte da ação humana, sendo que as caravelas contribuíram para uma expansão horizontal do conhecimento humano e o balão permitiu que, pela primeira vez, o homem saísse das prisões que a superfície da Terra lhe impunha. As cidades, principalmente aquelas com função comercial, começam a se desenvolver em decorrência das rotas de comércio que se estabelecem. A retirada das muralhas da cidade feudal possibilita também um contato maior entre a cidade e a natureza. As ações humanas se concentraram na dissecação da natureza, no entendimento de suas partes, cada vez menores, atreladas às ideias mecanicistas e atomistas da natureza. Neste período há uma forte influência do "descobrimento da montanha", ou seja, da conceituação da montanha, atrelada a uma "Alta Natureza", pura e imaculada - coberta pela mais branca e limpa neve. Na montanha o homem chegava perto de Deus. Neste período, a ação do homem sobre a Natureza revela paralelamente uma preocupação com sua ordenação estética, grandes jardins românticos e parques florestais atrelados a uma beleza natural/paisagem. O ambientalismo era estético - para a nobreza e a burguesia

O quarto período significou uma mudança na relação dos homens com a natureza, passando a incorporar uma forte cultura industrial. As fotografias e as litogravuras permitiram um estudo à distância da natureza, mesmo contando com cada vez mais facilidades de deslocamento, como os automóveis e aviões. Este período será marcado pela incorporação da natureza à vida social, tanto em função das técnicas desenvolvidas e aperfeiçoadas quanto da cultura vigente. A natureza passa a ser entendida como recurso. As cidades passam a concentrar a crescente produção industrial, incluindo também a poluição decorrente desta atividade. A expansão das cidades e de alguns bairros mobilizava a população, atraindo a parcela mais rica para os locais com grande presença de elementos da natureza, principalmente, áreas verdes e lagos.

O quinto período (atual) é marcado por uma mudança radical na perspectiva do entendimento da relação do homem com a natureza, devido a sua total incorporação ao território usado, através das imagens orbitais que permitem o conhecimento de toda a superfície do planeta. A sociedade urbana se estabelece definitivamente e as técnicas atingem, desde a escala planetária até a escala da célula, com os satélites e a genética, respectivamente. Os homens, cada vez mais, se encontraram na qualidade de produtores da natureza, tornando-a um artifício, entendido aqui não no sentido de uma mentira, de algo falso, mas sim como resultado da produção humana. As cidades passam a concentrar a maior parte da população e a natureza passa a ser produzida nas cidades com o intuito de melhoria da qualidade de vida. Torna-se num forte atrativo de capitalização para os diversos agentes econômicos, inclusive no mercado imobiliário nas grandes cidades. 
Quadro 02 - Caracterização e Evolução das Ideias ao longo dos Períodos

\begin{tabular}{|c|c|c|c|c|c|}
\hline Clássico & Teológico & Descobrimentos & Incorporação & produção \\
\hline $\begin{array}{c}\text { Origem das } \\
\text { Ideias }\end{array}$ & $\begin{array}{c}\text { Contemplação da } \\
\text { natureza e ińcio da } \\
\text { atividade agrícola }\end{array}$ & $\begin{array}{c}\text { Vida em função do } \\
\text { cristianismo; } \\
\text { construção de } \\
\text { grandes catedrais. }\end{array}$ & $\begin{array}{c}\text { Descobertas de novos } \\
\text { territórios; descobertas } \\
\text { científicas. }\end{array}$ & $\begin{array}{c}\text { Desenvolvimento } \\
\text { industrial; } \\
\text { mecanização das } \\
\text { forças da natureza }\end{array}$ & $\begin{array}{c}\text { Desenvolvimento } \\
\text { da Técnica e da } \\
\text { Ciência;Urbanização }\end{array}$ \\
\hline $\begin{array}{c}\text { Principais } \\
\text { Ideias }\end{array}$ & $\begin{array}{c}\text { O homem com sua } \\
\text { mão transforma a } \\
\text { primeira natureza } \\
\text { em uma natureza } \\
\text { segunda }\end{array}$ & $\begin{array}{c}\text { O homem deve } \\
\text { conhecer a natureza } \\
\text { para comprovar a } \\
\text { existência de Deus }\end{array}$ & $\begin{array}{c}\text { A ciência é a forma } \\
\text { racional de dominação } \\
\text { da natureza aos seus } \\
\text { interesses }\end{array}$ & $\begin{array}{c}\text { A Terra é o território } \\
\text { do homem. }\end{array}$ & $\begin{array}{c}\text { A natureza passa } \\
\text { a se inserir nos } \\
\text { interstícios da } \\
\text { vida social. }\end{array}$ \\
\hline $\begin{array}{c}\text { Principais } \\
\text { Expoentes }\end{array}$ & $\begin{array}{c}\text { Marcus Túlio Cícero } \\
\text { Marsílio Ficino }\end{array}$ & $\begin{array}{c}\text { Francis Bacon; } \\
\text { Buffon }\end{array}$ & $\begin{array}{c}\text { Karl Marx;Friedrich } \\
\text { Engels;George } \\
\text { Marsh;Elissée Reclus }\end{array}$ & $\begin{array}{c}\text { Santos;David } \\
\text { Harvey }\end{array}$ \\
\hline $\begin{array}{c}\text { Obras de } \\
\text { Referência }\end{array}$ & De Natura Deorum & Bíblia & $\begin{array}{c}\text { Novum organum; } \\
\text { Historia Natural }\end{array}$ & $\begin{array}{c}\text { Aapital; } \\
\text { Dialética da } \\
\text { Natureza; } \\
\text { Man \& Nature: } \\
\text { new physical } \\
\text { geography; }\end{array}$ & $\begin{array}{c}\text { A Natureza do } \\
\text { Espaço;Spaces of } \\
\text { Capital }\end{array}$ \\
\hline Filosofia
\end{tabular}

Organização e elaboração: Wendel Henrique, 2004.

\section{NOTAS}

${ }^{6}$ Para Foucault (2000, p. 156), "uma periodização recorta na história um certo nível de acontecimentos e, inversamente, cada camada de acontecimentos pede sua periodização, uma vez que, segundo o nível que se escolha, dever-se-á delimitar periodizações diferentes e, segundo a periodização que se dê, atingir-se-á níveis diferentes”. 
PARTE I

\section{A INCORPORAÇÃO DA NATUREZA À VIDA SOCIAL}





\title{
III - A NATUREZA E O HOMEM
}

\author{
O PERÍODO CLÁSSICO
}

A Natureza como beleza e o Homem como artesão - primeiros encontros e entendimentos A criação humana na natureza

A partir da periodização, definida de acordo com as formas como os homens e a natureza se encontravam e se entendiam, foram definidos cinco grandes períodos que abrangem deste a Antiguidade Clássica até os dias atuais. O primeiro período foi definido como Período Clássico. A natureza possuidora de uma maior influência sobre o meio encontra no homem mais um de seus elementos. Este período corresponde ao início da busca pela história da incorporação da natureza à vida social e à produção do espaço geográfico.

A destruição dos bosques e florestas foi, para George Marsh (1874), a primeira conquista geográfica do homem, sua primeira violação da harmônica natureza inanimada. Estas florestas e bosques foram transformados em combustível, moradias, embarcações e ferramentas, através de queimadas que eram fáceis de serem espalhadas e tinham por objetivo limpar a área e ao mesmo tempo produzir material orgânico para sua fertilidade ${ }^{7}$.

Neste período, ainda não eram feitas as grandes distinções entre homem e natureza. O homem era visto como um elemento da natureza e composto dos mesmos elementos que ela. Os principais elementos presentes na constituição da natureza eram: a terra, o fogo, o ar e a água, sendo que estes elementos eram eternos, imperecíveis e indestrutíveis. A natureza e seus elementos estavam tão intrinsecamente ligados aos homens, que estes também eram conectados e eram os controladores dos humores humanos. Conforme esclarece Glacken (1996), as variações fisiológicas e os fluídos do corpo humano possuem correlações com "elementos do macrocosmo": o ar (quente e úmido) possui vínculo com o sangue no corpo 
(coração); o fogo (quente e seco) está relacionado a bílis (fígado); a água (fria e úmida) com a fleuma (cérebro); e a terra (fria e seca) tem correlação com a bílis negra (baço). Estes quatro conjuntos de relações eram a base da Teoria Humoral ou dos Quatro Humores (o sanguíneo, o colérico, o fleumático e o melancólico, respectivamente), que sustentava as explicações sobre a saúde e vida humana nas concepções hipocráticas.

As primeiras formas de relação que os homens estabeleceram com a natureza, que ainda condicionava sua vida, era uma espécie de animismo da natureza. Lenoble (1969, p.42 e 50), explica que o animismo é a "propensão do sujeito para imaginar as coisas segundo o modelo da sua própria existência. O animismo é um produto da consciência. [...] animismo prova que a primeira ideia que os homens formaram da natureza foi uma ideia moral". O homem desde suas primeiras representações pictóricas mostra sua ação sobre a natureza.

\footnotetext{
Os primeiros desenhos que encontramos dos objectos naturais nas grutas pré-históricas, são imagens mágicas. O bisonte ou antílope figurado encontra-se rodeado de flechas ou ferido, ou então capturado por mãos que o cercam por todos os lados. Logo, o homem não surgia desarmado perante as coisas, 'sabia' já como tornar-se 'dono e senhor'. ${ }^{8}$
}

Nestes estágios iniciais da história da vida humana, com incipientes cultivos e criações, o homem dependia exclusivamente dos animais e vegetais para alimentação e vestuário. Neste sentido sua vida era a repetição de formas organizacionais ainda muito similares à natureza. De acordo com FérnandezArmesto (2001), as sociedades, nos seus momentos iniciais, aprenderam a fazer suas vidas com aquilo que a natureza providenciava. Elas viviam com os produtos e habitavam os espaços que a natureza fornecia. Construíam suas moradias numa imitação muito próxima dos espaços naturais e com os materiais que a natureza local disponibilizava. Em áreas florestadas, as moradias eram construídas de madeira; em áreas argilosas, as casas eram de barro; em áreas cársticas, as próprias cavernas eram adaptadas para a habitação.

Em função desta proximidade entre os espaços construídos pelas primeiras sociedades humanas, que ainda "engatinhavam" na busca para minimizar o grande grau de dependência, perante a natureza. Muitos registros sobre os primeiros assentamentos, que originaram as primeiras cidades, se perderam, devido à decomposição dos materiais utilizados. A deteriorização das casas seguiam os ritmos e ciclos naturais. Devido as constantes lutas entre as tribos e o abandono de alguns assentamentos, os registros também se perderam. 
Neste período, a riqueza natural intrínseca ao território, aqui compreendido como uma categoria do espaço geográfico vinculada à área da ação humana, será diretamente proporcional à riqueza da vida dos povos. Desde os tempos remotos, os homens têm desenvolvido técnicas para corrigir as desvantagens naturais quando elas aparecem, mesmo no Período Clássico, ainda de maneira muito rudimentar. Quanto maior a fertilidade dos solos maior será a produtividade agrícola e a disponibilidade de alimentos para serem coletados e colhidos, portanto maior será o fornecimento de comida ao grupo. Quanto melhor o acesso aos meios naturais de transporte e a presença de água, mais propícios são os lugares para os estabelecimentos humanos e maiores as possibilidades dos homens na sua expansão. O oposto também pode ser verificado, pois neste período as desvantagens naturais também podem criar empecilhos para os grupos humanos assentados em locais com uma configuração física territorial desfavorável. George Marsh (1965) cita as componentes geológicas/pedológicas como desvantagens naturais, principalmente o solo, cujo uso intenso para aquele momento provocou um processo de desertificação em algumas localidades.

Neste período, ${ }^{9}$ cabe destaque as concepções gregas da ideia de natureza. O que mais chama a atenção nas mitologias e concepções gregas da natureza é o desejo de união entre um propósito e uma ordem ${ }^{10}$. Já para Marsh (1965), neste período, existe uma intuição de natureza espontânea. A natureza é representada por relatos de inebriantes colheitas e luxuriantes jardins. As tentativas de "enobrecimento e embelezamento" da natureza, notadamente de seus padrões estéticos, são constantes ao longo da história das relações entre a cidade e a natureza, através da arte e do trabalho. As glorias da paisagem têm sido elevadas pela plantação, arquitetura decorativa e outras formas de pitorescos melhoramentos, conforme escreveu Marsh (op.cit.).

O filósofo grego Panécio ${ }^{11}$ explica que autores gregos ${ }^{12}$ e romanos pensaram uma natureza domesticada, uma simpática mescla de natureza e arte, nas aldeias da costa mediterrânea, na beleza dos campos cultivados, nas vinhas e nos olivais nas encostas das colinas. As cidades sempre dispostas junto a um rio ou perto de um bosque.

A respeito da ideia de natureza como uma forma de beleza luxuriante e, associada a um ordenamento dentro de um jardim, cabe fazer uma referência aos famosos Jardins Suspensos da Babilônia. Reais ou não, instituíram na mentalidade clássica a ideia do poder humano no embelezamento da natureza, bem como seu controle. Estes jardins, de acordo com Fernandez-Armesto (2001), criaram um apelo através da invocação de uma imagem descrita pelos gregos, como uma cascata de terraços tão altos quanto os muros de uma cidade, suportados por arcos fortes o bastante para sustentar o peso da terra posta para segurar as grandes árvores. A água, vinda do Eufrates, descia em patamares. O propósito estético da construção 
dos Jardins da Babilônia foi evocar uma paisagem montanhosa numa extensa planície. Uma construção humana produzida diferentemente da constituição geomorfológica natural da área, bem como da própria vegetação local, rarefeita devido a indisponibilidade hídrica. Os Jardins se configuraram pela produção de uma forma-conteúdo ${ }^{13}$ artificial que, segundo os ciclos da natureza, nunca teriam existido naquela região. Os Jardins Suspensos da Babilônia representavam, sem uma conotação abertamente religiosa, um dos objetivos que todas as outras "Maravilhas do Mundo Antigo" tinham em comum: o desafio à natureza numa grande escala, transformando a "paisagem natural".

Esta influência dos jardins no pensamento e no entendimento da natureza no Período Clássico é de grande importância. Segundo Glacken (1996), a presença contemporânea de jardins e ruas arborizadas indicam um claro desejo de reprodução de pequenos reinos da natureza dentro das cidades.

\section{A INTERPRETAÇÃO E CONTEMPLAÇÃO DA NATUREZA}

As bases das interpretações da natureza estão nos tratados romanos, gregos e persas sobre as formas e as técnicas de melhoramento do solo, cujo principal objetivo era, sem dúvida, a produção de alimentos. Mesmo que rudimentares, as técnicas de irrigação, controle de insetos e fertilização se constituíram em importantes fontes de conhecimento para o entendimento da ordem e propósito da natureza.

De acordo com o filósofo Filón, na obra Sobre a criação (apud Glacken, 1996), a relação de proximidade com a natureza também era fruto das crenças dos povos da Antiguidade Clássica. A natureza era admirada e homenageada como a semente da fertilidade da terra e dos homens. Desta relação religiosa surgiram muitos mitos e rituais para explicar este laço entre natureza e fertilidade. A natureza teria outorgado a toda mãe um dom muito especial, a possibilidade de amamentar seus filhos.

Já para Aristóteles (Glacken, 1996), a natureza, assim como o homem, é um artífice, entretanto um artífice infinitamente mais poderoso. Nas obras da natureza dominam o propósito e não o acidente. O que é belo ocupa um lugar central. Nestas concepções aristotélicas, apesar de uma posição proeminente na natureza, o homem ainda é muito mais fraco. De acordo com Lenoble (1969, p. 28), enquanto os primitivos buscavam na natureza "compreender a vontade dos deuses, do mar, dos vulcões e dos rios, Aristóteles [buscava construir] uma hierarquia das formas organizadas". Da abordagem sobre as formas da natureza ao exame da natureza, constituia-se com Aristóteles, segundo Lenoble (1969), um estudo fisionômico ${ }^{14}$. 
O homem era considerado um artífice individual, um carpinteiro que constrói uma casa ou qualquer obra sabendo qual será o seu resultado ou produto final. Esta ideia estava em consonância com a ideia de propósito. Para Lenoble (1969), a concepção de natureza de Aristóteles e Platão é o da morada do homem e feita para o homem.

Lucrécio (De natura rerum apudLENOBLE, 1969) escreve que a historicidade do homem se dá pela historicidade da natureza, um universo onde a "a humanidade e a Natureza puderam modelar-se uma pela outra”. Neste parágrafo de Lucrécio estão as bases da interpretação dialética da natureza ${ }^{15}$.

Também era fonte de influência no pensamento clássico sobre a natureza o incremento das viagens e comunicações entre os povos. Num primeiro momento da história do homem sobre a Terra, como escreve Reclus (1985), os grupos humanos viviam isolados e não se comunicavam. As bordas das terras conhecidas eram povoadas por monstros e bestas, que amedrontavam os homens que questionavam os limites impostos. Ao redor do ano 117 a.C., segundo informações de Glacken (1996), com a descoberta de uma rota marítima para a Índia, se iniciam formas de intercâmbio. As regiões da Europa mediterrânea conectaram-se com o mundo antigo.

Estas viagens e os mitos da natureza irão influenciar, por exemplo, a visão que Homero tinha da natureza. De acordo com Glacken (1996), no imaginário da natureza em Homero ela é viva, mas está extremamente vinculada a atividade dos Deuses, as quais a referem. O período helênico teve a tendência a ver os aspectos da natureza tais como realmente são.

O melhor conhecimento da geografia, das experiências do comércio, as viagens e as explorações, que permitiam a comparação de paisagens, são apreciados claramente na literatura. A poesia da natureza e a descrição da paisagem no helenismo não têm igual em nenhum momento anterior do mundo clássico. [...] o interesse pela natureza, animado e intensificado por inspirações procedentes do Oriente (como o jardim) e combinado com o incremento da vida urbana, agudizaram a distinção entre natureza e $\operatorname{arte}^{16}$.

Isto significa uma crescente preocupação estética. A natureza é a fonte de grande contemplação e a matéria original para as futuras "imitações" e aproximações. Também se destaca o início de um processo de interpretação antropocêntrica da natureza.

Outra forma de mediação entre a natureza e o homem se construiu através do interesse dos povos da Antiguidade Clássica pela Astrologia, relação está que será de fundamental importância para os futuros desdobramentos do entendimento que a humanidade fez e faz sobre a natureza. O fato curioso, segundo Glacken (1996), é que estes povos estavam muito mais interessados na observação da Lua 
do que do Sol. Esta "preferência" era resultado da crença que a Lua possuía forte influência na fertilidade da terra e das mulheres. Outra interpretação recorrente era que os cometas e as estrelas cadentes eram formas de "desordem" da natureza e que representavam interferências em uma ordem natural.

Estes são apenas poucos exemplos das riquezas de formas de interpretação, representação e descrição da Natureza feitas no Período Clássico. Outras grandes contribuições foram dadas de: Virgílio e Heródoto ${ }^{17}$. De acordo com Glacken (1996), estes filósofos tinham em comum a ideia de que o homem era participante de diferentes formas de criação. O homem era considerado como um artífice individual, um carpinteiro que constrói uma casa ou qualquer obra sabendo qual será o seu resultado ou produto final. Esta ideia estava em consonância com a ideia de propósito.

\section{A CRIAÇÃO DE UMA SEGUNDA NATUREZA - MARCUS TULLIUS CÍCERO E OS ESTÓICOS}

A estética também era a fonte de reflexão dos filósofos estóicos, cujas obras possuíam forte caráter sensualista. Os estóicos também eram apreciadores dos aspectos visíveis da natureza, revelando ou desvelando as belezas da Terra.

Deste grupo de filósofos destaca-se Marcus Tullius Cícero (De natura deorum ou The nature of Gods - A Natureza dos Deuses). Para este filósofo é belo contemplar a natureza; sua beleza deve ser conservada. A contemplação é útil porque estimula o exercício da mente do homem, cujas criações, instrumentos e máquinas mudam e melhoram a natureza, para satisfazer as crescentes necessidades humanas. O homem é, num sentido muito integral, parte da natureza; desenvolve-se em seu meio e é afetado pelo mesmo. Salienta-se, nesta fala de Cícero, a ideia de que o homem é um agente na melhora e no embelezamento da natureza. Destaca-se também outra ideia dialética, pois ao mesmo tempo que modifica o meio, o homem é afetado/modificado pelo mesmo. Embelezar a natureza significa embelezar o próprio homem, suas cidades e seus espaços.

Cícero escreve que os logros tecnológicos do homem, seus inventos e as mudanças na natureza resultam de combinações entre a destreza da mão, dos descobrimentos da mente e das observações dos sentidos. O homem, com sua presença criadora, participa de uma razão universal, que penetra o todo e, em particular, a Terra. Esta ação tem como testemunho as adequações da natureza exterior, como as encontradas no Nilo, no Eufrates e no Indo - que existem para a preservação do homem. Assim, pode-se concluir que o Egito é mais do que uma dádiva da natureza do Nilo, é também um presente da "natureza" e da ação/trabalho dos egípcios, que 
aprenderam a transformar e melhorar a natureza, construindo, por exemplo, canais que permitiram que seus cultivos e sua cultura se expandissem sobre áreas naturalmente impróprias para agricultura.

É de Cícero uma das chaves para o entendimento da ação humana sobre a natureza. Segundo Cícero, o homem procura com suas mãos humanas criar uma segunda natureza dentro do mundo natura ${ }^{18}$. A mudança do meio pelo homem, a criação de uma segunda natureza dentro do mundo natural, se explica por uma diferença qualitativa entre o humano e o animal. O homem é uma criatura que pensa, sua experiência é acumulada através do tempo, permitindo inovação e invenção. O homem participa da vida criativa e do espírito que penetra o mundo inteiro.

Pelo trabalho do homem, ou melhor, por suas mãos, este encontrou alimentos e sua variedade. Com efeito, a mão humana fez surgir nos campos frutas que são consumidas imediatamente ou preparadas para consumo futuro. Na variedade de sua alimentação, os homens comem carne de animais terrestres, aquáticos e de aves. Também foram domesticados animais quadrúpedes para transporte e uso de sua força. Extraí-se o ferro da terra utilizando-o para cultivar os campos; o mesmo se dá com o cobre e o ouro, descobertos em veios sob a terra, utilizados tanto para as necessidades cotidianas como para demonstrar luxo. Cortam-se árvores e tudo o que pode ser queimado; quer seja produto do cultivo do homem ou que esteja em estado selvagem; dispõe-se destes materiais para a produção de fogo, usado para o aquecimento das casas e no cozimento de comidas; Constrói-se casas para abrigo contra o frio e contra o calor. O corte destas árvores assegura a vantagem da construção das próprias moradias onde se desenrola a vida. O que a natureza tem de mais impetuoso - o mar e os ventos - são utilizados pelos homens na arte da navegação; $O$ homem torna-se senhor das obras da natureza sobre a terra, aproveitando-se das planícies, das montanhas; os rios e lagos são dos homens; são os homens quem semeiam o trigo, que plantam árvores; são os homens que conduzem a água sobre as terras para lhes dar fertilidade; controlam-se e desviam-se fluxos d'água; as mãos humanas, fazem dentro da natureza uma natureza nova, uma segunda natureza. ${ }^{19}$

Para Smith (1984), a concepção de segunda natureza criada por Cícero se manterá até o século XVIII, quando o Conde Buffon (ver capítulo IV) propor uma nova explicação dialética da transformação da natureza. 
Outro filósofo estóico que também tem posições semelhante e importante, na vertente em que se situa este trabalho, e para o entendimento das ideias de natureza na geografia, é Posidônio. De acordo com Posidônio (apud GLACKEN, 1996), o homem com sua inteligência, com suas inumeráveis conquistas, é parte da natureza. Seus poderes são derivados da natureza e lhe possibilitam uma posição vencedora e vaidosa, a partir de uma ampla variedade de investidas. Possibilidades e habilidades negadas as plantas e aos animais. De acordo com Glacken (1996), nas bases do pensamento de Posidônio estão as ideias de geografia, biologia, historia, astronomia, ecologia e etnologia.

A ênfase na estética e na beleza da natureza também é encontrada na obra de Estrabão - Geografia. Para Estrabão ${ }^{20}$, de acordo com Glacken (1996), o geógrafo deve somente dedicar-se ao estudo das porções da Terra habitadas pelos homens. O homem é um "sócio" da natureza. A natureza é um cenário para os acontecimentos históricos.

A possibilidade dos homens ${ }^{21}$ produzirem na natureza, através de seus ofícios, habilidades e ocupações, sua vida cotidiana é dada pela necessidade que a natureza lhes impunha, ou pela tentativa de retificar as deficiências da natureza. Estas ações marcam o início do processo de emancipação coletiva da humanidade perante a natureza. Um projeto dominante em muitas sociedades.

Dentre as formas que os homens construíram para se estabelecer dentro da natureza, neste primeiro período, ou dentre as necessidades da vida cotidiana que possibilitaram o acúmulo de conhecimento para a melhora da natureza, destaca-se, segundo Férnadez-Armesto (2001):

- o estabelecimento de aldeias;

- a domesticação de animais (criações);

- o cultivo do solo (agricultura e produção de alimento);

- $\quad$ as irrigações de terras e a drenagem de pântanos;

- a metalurgia.

Para Glacken (1996), o homem criava ordem e era agente de gestão; era possuidor da destreza única do artesão. Já para Marsh (1965), foi a agricultura e as atividades pastoris que ampliaram a esfera do domínio humano.

De acordo com Glacken (1996), ao se ler os comentários dos autores antigos sobres as mudanças causadas pelo homem na natureza, tem-se uma dupla impressão. Primeiramente, havia um reconhecimento do homem como ser ativo que se 
esforça e obtém sucesso, perante as dominantes influências ambientais. A segunda impressão é que natureza vivente que estes homens observaram - e muitas vezes amaram - era, como agora se sabe, uma natureza muito modificada pelo homem ${ }^{22}$. Continua o autor (op. cit.), para os gregos e romanos os vinhedos, os olivais, as cabras pastando nas montanhas rochosas, as aldeias e as vilas eram inseparáveis da paisagem das áridas colinas no verão mediterrâneo, assim como os ventos, o azul profundo do mar e os céus radiantes. Era uma paisagem alterada pelos homens, que a contemplavam com atenção e cuja múltipla beleza amavam.

A forma como o homem clássico somou seus esforços no contínuo processo de melhora da natureza, bem como de suas ideias e conceitos, representou um grande avanço na epistemologia da natureza. Mas o Período Clássico estava chegando ao fim com o advento do cristianismo e das invasões dos territórios europeus, pelos povos asiáticos, que os "civilizados" europeus chamavam de bárbaros. A mudança do eixo de produção de ideias do Mediterrâneo para a Europa Central e do Norte, irá significar o abandono da ideia do homem como um criador na natureza. Será instaurada a ideia de um Criador Divino na concepção de toda a natureza.

\section{O PERÍODO TEOLÓGICO}

A Natureza e o Homem - equilíbrio nos encontros e entendimentos

A Natureza divina e o Homem religioso

Após a contribuição intelectual do Período Clássico, os rumos da história da humanidade e da produção do conhecimento tomam novas direções. Os novos tempos, marcados notadamente pela dominação do cristianismo, tanto do ponto de vista religioso como político, significou uma nova forma de produção de ideias de natureza e no desenvolvimento científico e técnico.

O fim do Período Clássico, que no mundo das ideias já esboçava um importante conjunto teórico que sustentava a ideia do homem como um ser independente e controlador da natureza, e o início do Período Teológico, serão marcados pela superação das ideias do homem como um criador/artesão na natureza. O novo ideário dominante para a conceituação da natureza terá como aspecto central o teocentrismo. A Natureza é vista como obra e criação de Deus. O seu estudo será marcado pela busca de novas provas da existência e da bondade deste ser criador. Para Lenoble (1969), a ideia de uma criação divina da natureza, uma natureza que não existe por si mesma, é uma ideia religiosa judáico-cristã. 
A ruptura do pensamento teológico com as ideias clássicas de natureza e do homem, também significou uma mudança geográfica de sua área de produção, pois as ideias cristãs se desenvolveram muito mais no norte ocidental da Europa, menos afetada pelo pensamento clássico, que na Europa mediterrânea.

Salienta-se, como no período anterior, que o objetivo neste capítulo é construir um panorama geral da ideia e dos conceitos de natureza no Período Teológico. Busca-se mostrar um continuum da epistemologia da ideia e conceitos de natureza. As obras que são utilizadas referem-se apenas às ideias e conhecimentos produzidos sob os olhos do cristianismo e tendo como espaço a Europa Ocidental.

\section{BASES TEOLÓGICAS}

Retomando o encontro da natureza com o homem, este passa a ser mediado pela Teologia. A principal fonte de informação sobre a natureza e "livro guia" será a Bíblia ${ }^{23}$. A natureza configura-se como uma natureza fisicoteológica, vista como uma prova física importantíssima para demonstrar a existência de um Criador. A natureza, ou a criação, possui um desígnio, definindo no processo de elaboração desta prova. Constata-se uma intensificação, uma aceleração e uma concentração dos interesses religiosos nos processos da natureza. Provar a existência de um desígnio divino implicava considerar o caráter presumidamente ordenado da natureza, garantindo uma via aberta para a concepção da natureza, como equilíbrio e harmonia ${ }^{24}$.

O Cristianismo também insere uma mudança na noção do tempo para o homem e para mundo, que passa a se configurar como algo linear e não renovável. Já a natureza possuiria um tempo cíclico, de acordo com a obra De divisione naturae, do irlandês Johannes Scotus Erigena (citado por GLACKEN, 1996). Todas as coisas da natureza sempre voltam ao seu ponto de origem.

A regularidade cíclica pela qual a natureza mantém o seu curso, observáveis nas estações do ano e na vida animal sobre a Terra, trabalhadas pelo pensamento clássico, são trazidas para o universo teológico. Os ciclos constatemente repetidos explicam e comprovam a harmonia divina entre o homem, Deus e a natureza, bem como de sua ordem e hierarquia ${ }^{25}$.

Segundo Simmons (1993 apud GLACKEN, 1996), as noções de tempo, introduzidas pelo pensamento judaico-cristão, conduziram a uma noção de progresso contínuo e a disponibilidade de tempo suficiente para a constituição de um mundo perfeito. A ideia de um Deus bom, que ama o mundo e a suas criaturas, demonstrado através das belezas da Terra, sua criação. Este Deus ainda instiga a 
multiplicação dos homens, para lograr o domínio de todas as demais formas de $v$ ida $^{26}$. Entretanto, apesar de mostrar compaixão pela humanidade e do desígnio a "supremacia" do homem, criado a imagem e semelhança de Deus, sobre as demais obras da criação, não se deve esquecer que o centro e o destino da vida cristã não está neste mundo, mas no que está após o fim da vida terrena, a vida no Céu. Observa-se que o homem, o auge e a finalização da criação divina é visto como possuidor de um direito teológico de domínio da natureza. Diferentemente do Período Clássico, este domínio é cedido pela vontade Divina, pelo Senhor da Criação, e não pela ciência, técnicas e artes como no período anterior ${ }^{27}$.

O homem, que obtivera o direito ao domínio da natureza pelo desígnio de Deus, seu criador e mestre, irá desafiá-lo, perdendo sua confiança. Neste sentido a expulsão de Adão e Eva do Paraíso (A Queda) constituirá uma forte presença no entendimento da relação da natureza com o homem no Período Teológico.

Segundo Glacken (1996), o relato da Queda adquiriu grande importância para a ideia cristã de natureza. Fonte de crença, muito difundida até no século XVII. O pecado é o responsável pela "desordem", infertilidade e esgotamento das dádivas da natureza, uma ideia que se diferencia claramente da ideia clássica do envelhecimento natural, a qual era baseada em analogia orgânica entre a terra e as mulheres. $\mathrm{Na}$ medida em que ambas envelhecem perdem sua fertilidade. Salienta-se, que a partir da instauração do Pecado, a natureza bondosa deixa de suprir as necessidades humanas, sendo necessário agora o trabalho sobre a natureza. Será o trabalho na terra e o desenvolvimento de formas de produção daquilo que anteriormente era fornecido/dado que proverá os homens em suas necessidades.

Todas as relações entre o homem e a natureza são mediadas por Deus, inclusive as catástrofes naturais, como o relatado no Dilúvio. As catástrofes são atribuídas aos pecados dos homens e a necessidade da ratificação da supremacia do poder Divino sobre a vida e sobre a superfície terrestre. Nota-se que os cristãos, que sofriam com estas catástrofes, estavam pagando também pelo falta de crença dos pagãos ou de outras religiões não-cristãs.

A posição de Deus, como o centro do universo e controlador da natureza (clima, mares, terras), é a ideia chave para entender a posição do homem na natureza. O Salmo 104, que segue a cosmologia do Gênesis, é muito revelador desta ideia. Consultando três Bỉblias, duas em português e outra em inglês constata-se que todas apresentam significativas diferenças em relação aos vocábulos e na glorificação da obra de Deus. As versões em português glorificam mais o Senhor e apresentam alguns vocábulos geográficos mais simplificados ou errôneos, comparativamente à versão em inglês. ${ }^{28}$

As passagens do Salmo 104 refletem a alegria de Deus e de suas criaturas na natureza, apresentando uma ordem e uma grande conexão entre suas partes. Deus 
não é a natureza, como nas concepções animistas onde Deuses e Natureza se mesclam, mas pode ser entendido a partir dela. O homem seria mais uma das criaturas dentro da natureza, em uma posição hierárquica superior. Esta posição denotava certos direitos sobre as demais obras da criação. Mas estes direitos estão sob o julgo imediato de Deus.

As concepções judaico-cristãs sobre Deus e sobre a ordem da natureza foram, segundo Glacken (1996), muitas vezes combinadas com o argumento clássico de desígnio e com a ideia da divindade artesã. Criou-se uma concepção do mundo habitável de tal força, poder de persuasão e flexibilidade, que esta poderá se manter como uma interpretação da vida, da natureza e da Terra aceitável para a grande maioria dos povos do mundo ocidental até o século XIX.

Mas não foi só a leitura da Bíblia, apesar de dominante, que influenciou as opiniões dos homens sobre a natureza na Terra, a morada divina. Para Glacken (1996), algumas contribuições da física, da biologia e do pensamento clássico, foram subordinados a uma leitura "bíblica" no sentido de apoiar as ideias e conceitos presentes nos textos, justamente em pontos que mais necessitavam de complementações. Até porque, durante a Idade Média, foram realizadas várias intervenções humanas na natureza como, por exemplo: desflorestamento, drenagem de terras, construção de mosteiros, igrejas, catedrais, entre outras.

Também não se pode esquecer, que neste primeiro momento do Período Teológico, estava presente ainda uma influência Romana, que se encontra, segundo Glacken (1996), em uma interpretação dos escritos "pagãos" ou aqueles referentes ao pensamento clássico, a serviço do cristianismo. O argumento de desígnio ou finalidade da natureza foi reformulado seguindo os preceitos cristãos. A beleza da Terra e da natureza era prova da harmonia divina e da bondade de Deus.

De acordo com o filósofo da época Clemente de Alexandria (citado por GLACKEN, 1996), segundo a vontade de Deus, a terra propicia alimento suficiente para a sobrevivência do homem e dos animais domesticados, de acordo com a sucessão das estações do ano, as quais completam e retomam seus ciclos "pacificamente". O menor ser vivente segue sua vida em "paz e harmonia" segundo os desejos do Senhor, sem conflitos. A vida segura, tranquila e harmônica é um presente a toda sociedade, mas torna-se mais abundante e plena para os homens que encontram a religião e a bondade do Senhor, ou seja, os cristãos.

Tudo ocorre segundo a vontade de Deus. Não há possibilidades de alteração ou renúncia à sua vontade e, portanto, só resta aos homens sua obediência. Já a utilização da natureza como prova da existência de Deus é baseada na observação cotidiana da natureza e no conhecimento superficial dos ciclos naturais. Sendo que, 
desta observação, surge uma explicação circular tanto da natureza como do seu desígnio. As estações seguem umas as outras, assim como a lua procede ao sol. Esta natureza da natureza se supõe como resultado da divindade superior e também serve como prova dela mesmo.

A ideia do mundo ou natureza como um livro, originado na "eloquência do púlpito", de acordo com Glacken (1996), foi logo adotada pelo senso comum. Os escritos que interpretavam as "desordens" da natureza como fruto do pecado original (Queda do Paraíso), descreviam a criação de insetos e plantas venenosas como formas de Deus lembrar aos homens seus pecados, orgulhos e enganos.

Deve-se atentar ainda que a relação com os elementos e criaturas da natureza seguia uma hierarquia, definidas por Santo Agostinho, como uma ordem natural na Terra. Para Glacken (1996) nas obras de Santo Agostinho a ordem ou hierarquia natural separa uma ordem real da natureza e as normas de valor, julgadas pelos seres humanos. Na posição hierárquica superior estão as "coisas viventes", as quais são superiores as "coisas sem vida". Os seres sensitivos, como os animais estão no topo e os seres vivos não sensitivos, como as árvores, na base. Entre os seres viventes superiores, os providos de inteligência ocupam melhores posições que os desprovidos de inteligência. Finalizando a hierarquia, entre os seres vivos sensitivos inteligentes, os anjos seriam superiores aos mortais.

Já a visão de natureza para São Francisco foi dada, segundo Glacken (1996), pela ênfase na comunhão do homem com a natureza, bem como da humanização da vida não humana, com a definição de valores pressupostamente humanos à natureza. No Cântico do Irmão Sol, São Francisco retoma uma ideia do Período Clássico, a doutrina dos elementos:

- o Irmão Sol é símbolo do Senhor;

- a Irmã Lua é o símbolo da natureza brilhante, charmosa e bela;

- o Irmão Vento representa o ar e sustento das criaturas;

- a Irmã Água possui como valores a utilidade, humildade, amabilidade e castidade;

- o Irmão Fogo é o símbolo da beleza, alegria, poder e força;

- a Irmã Terra é a que nos sustenta e nos governa.

Segundo Glacken (1996), o pensamento de São Francisco foi revolucionário em relação a natureza, pois o santo se rebela em sua humildade contra o antropocentrismo egoísta do pensamento da teologia anterior, onde o homem esta- 
va numa hierarquia natural superior. São Francisco foi o primeiro a ensinar na Europa, que a natureza é interessante e importante por si mesma. Mas, para a abordagem que é seguida neste trabalho, o mais importante da obra de São Francisco foi à ênfase na definição de valores morais á natureza, pois esta ideia irá permear o entendimento que o homem faz da natureza até os dias atuais.

Outro texto fundamental é a obra de Alberto Magno - De natura lococrum, o qual pode ser considerado um marco para a doutrina do Determinismo Geográfico. Segundo Glacken (1996), é o mais elaborado texto de teoria geográfica em relação à cultura humana desde alguns textos da Antiguidade Clássica, tendo sua origem na necessidade de conhecimento em detalhe da natureza dos lugares. Isto levou Alberto Magno expressar seu interesse pela natureza, história natural e geografia, retomando as obras gregas e latinas, através dos árabes, bem como da teologia e da astrologia ${ }^{29}$.

\section{O DOMÍNIO DO HOMEM SOBRE A NATUREZA}

Como observado desde o início do Período Teológico, a relação de dominação e controle da natureza pelo homem está presente, com uma nova roupagem vinculada a uma hierarquia natural definida no ato da Criação do mundo. O homem criado à imagem e semelhança de Deus tem o direito a uma posição elevada entre as criaturas terrenas.

Com as Cruzadas, o ocidente europeu cristão encontra o Oriente. Amplia-se o desenvolvimento técnico e, também como proporciona-se a contemplação de novas formas de entendimento da natureza. Uma das formas que será de fundamental importância neste 'intercâmbio' entre civilizações será novamente o jardim.

Geograficamente, a nova forma de inserção do homem na natureza, nos últimos séculos da Idade Média, irá representar algumas mudanças mais aceleradas da paisagem. A derrubada da vegetação de bosques e florestas para o estabelecimento das ordens religiosas e a preparação de terras para o cultivo estão ratificadas pelo pensamento teológico. Além disto, este homem que estava transformando a natureza era um homem rural, um homem que vivia no campo. De acordo como Lenoble (1969, p.205), o homem da Idade Média, até mesmo o homem comum no Renascimento, é um homem que "fica na sua terra, ou na sua aldeia, o homem das cidades não representa mais que uma percentagem ínfima e estas cidades parecernos-iam hoje simples aldeolas."

Novas técnicas são criadas e outras são aperfeiçoadas neste levante contra a "natureza primitiva". Uma das principais formas de aceleração do trabalho na terra foi à implementação e melhoramento do trabalho animal, principalmente os 
cavalos (novas raças foram trazidas do Oriente durante as Cruzadas). Esta inserção do trabalho animal aumentou a capacidade do homem para transformar a natureza, deixando marcas na paisagem, desde a modificação de áreas florestais em áreas para cultivo, até na própria agricultura e no transporte, tanto de mercadorias quanto pessoas. Os moinhos movidos pela força das águas e dos ventos também possibilitaram o aumento do controle do homem sobre a natureza, mesmo que inventados anteriormente nas áreas mediterrâneas, será no norte europeu que seu uso irá se multiplicar e se aperfeiçoar.

Estes avanços técnicos e, principalmente, as modificações no pensamento teológico sobre o papel do homem na natureza irão constituir os estopins para a mudança de período e, de forma mais "brusca" que entre o Período Clássico e o Teológico. Se nos dois primeiros consideraram-se momentos em que a natureza se relacionava com o homem, a partir deste momento de ruptura no final da Idade Média, o homem é que passa a se relacionar com a natureza. Mais do que uma simples mudança na posição das palavras, isto significa uma alteração no jogo de relações e poder entre homem e natureza ${ }^{30}$.

No final do Período Teológico, que coincide com o final da Idade Média, chega-se a conclusão que todo este período de mais mil anos foi marcado pela ideia que o conhecimento sobre a natureza era muito mais baseado nas relações dos homens com seu Deus do que nas relações destes mesmos homens com a natureza. Isto fez com que a natureza se mantivesse um tanto protegida pela sua áurea divina.

Mas como salienta Workman (1962 citado por GLACKEN, 1996), como em todas as épocas da história humana, a modificação do meio físico tem vínculos com ideias, com ideais e com necessidades práticas. A Idade Média coincide com o período de construção das grandes catedrais, que encarnavam um ideal religioso, mas significavam grandes transformações nos processos de extração mineral e do entalhamento das pedras, que seriam empregadas nas construções. Nos três séculos entre 1050 e 1350, os canteiros de obras da França elevaram oitenta catedrais e quinhentas grandes igrejas.

Segundo Glacken (1996), os temas cristãos sobre o homem perante a natureza e a filosofia do trabalho (o trabalho pesado, mesmo nas ordens religiosas era feito pelos leigos, pois o trabalho ainda estava associado ao pecado original), se casavam muito bem com as necessidades práticas de uma nova civilização, baseada na exploração da madeira e da água, como aquela que estava se desenvolvendo na Europa ocidental.

Na Idade Média, segundo Reclus (1886), a terra era cultivada pelos escravos, cuja existência sofrida era repassada para uma relação amarga com a natureza. Não havia prazer em observar as belezas divinas na natureza uma vez que suas próprias 
vidas eram verdadeiros infernos. É muito interessante o comentário de Reclus, sobre as ideias dos cristãos a respeito da natureza durante a Idade Média, consideradas muito estranhas. As ideias sobre a Terra e suas belezas para os monges da Idade Média, são representadas em seus mapas do mundo. Eram desenhados, ao lado dos nomes de cada distante país, estranhos animais vomitando fogo, homens com patas de cavalo ou rabos de peixes, grifos com cabeças de carneiro ou bois, dragões alados e corpos sem cabeça com selvagens olhos colocados no meio de seus peitos $^{31}$. Esta ideia levou a uma interpretação errônea da ideia de natureza, uma vez que as bordas da natureza, o desconhecido, apenas produziam medo e todo homem procurava paz e alegria.

\title{
NOTAS
}

\begin{abstract}
7 De acordo com Reclus (1985, p. 41), "durante a infância das sociedades, isolados ou agrupados em tribos frágeis, os homens tinham de lutar contra obstáculos tão numerosos, que não podiam sonhar em se apropriar da superfície da Terra como seu domínio: aí viviam, escondidos e temerosos, como os animais selvagens das florestas; sua vida era uma luta ininterrupta sob constante ameaça da fome ou do massacre, não podiam dedicar-se à exploração da região e ainda desconheciam as leis que lhes teriam permitido utilizar as forças da natureza. Mas a força do homem se mede pelo seu poder de acomodação ao meio".Dentro desta perspectiva, Lenoble (1969, p. 39) escrevendo sobre os primeiros encontros com a natureza, fala que "o homem não é lançado na natureza como uma pura ignorância 'sobre a qual nada há escrito'. Tem de imediato as suas ideais respeitantes à Natureza; optou por meios de acção, e essas ideais e esses meios são mágicos. Muito mais que a ignorância, que seria permeável ao real, esta ideia, rica de conteúdo afectivo, será em todos os tempos e para nós ainda a grande fornecedora dos 'obstáculos epistemológicos' que se oporão às descobertas objectivas."
\end{abstract}

${ }^{8}$ Algumas figuras rupestres da Serra da Capivara/PI ilustram muito bem esta ideia.

${ }^{9}$ Cabe salientar que, em se tratando de uma periodização numa escala temporal extremamente longa, todo o período da Antiguidade Clássica, as ideias trabalhadas no início do período são, muitas vezes, extremamente diferentes daquelas do final do mesmo período, apesar de suas conexões.

${ }^{10}$ GLACKEN (1996).

${ }^{11}$ PANÉCIO (apud GLACKEN 1996). 
12 Para Lenoble (1969, p. 54), "o pensamento grego, do qual provém toda a civilização da Europa, consistiu de tal forma o tipo dominante da história humana que a maior parte das vezes nos referimos a ele como se a consciência nunca tivesse conhecido outros triunfos. [...] A Natureza que os Gregos imaginaram e que nós lhes tomamos de empréstimo não era senão uma das ideias possíveis, não foi senão uma das ideias que efectivamente triunfaram. [...] A nossa Natureza é essencialmente jurídica e mecânica [...]".

${ }^{13}$ A ideia de forma-conteúdo é aqui empregada como uma morfologia construída e preenchida por um conteúdo específico intencional, nunca espontâneo.

14 "Aristóteles conceptualiza a Natureza. Quer estabelecer o inventário dessas coisas novas que acabam de adquirir uma consistência de 'factos', estudá-las por elas e pô-las em ordem. [...] Esta Natureza era, efectivamente, para o homem uma morada cómoda. Ele projecta sobre ela as suas percepções de senso comum [quente/frio; pesado/leve], as únicas que possuía antes da invenção dos instrumentos". (LENOBLE, 1969, p. 72/73)

${ }^{15}$ De acordo com Lucrécio (apud LENOBLE, 1969, p. 108), "as primeiras noções relativas à sementeira, à enxertia, foi a Natureza que as forneceu em primeiro lugar. Depois de cada um passou de tentativa para tentativa em seu pequeno domínio. Da mesma forma, foi o curso regular dos astros que ensinou aos homens a alternância das estações 'e que uma ordem (ordo) imutável governa a Natureza. E o homem aprendeu a guardar o fogo utilizando o raio, a produzí-lo observando a maneira como ele nasce da fricção de dois ramos".

16 GLACKEN (1996).

${ }^{17}$ Sobre estes autores consultar a coleção Great Books of the Western World, publicado pela Encyclopedia Britannica.

18 "Nos mains enfin essaient, pour ainsi dire, de faire dans la nature une nature nouvelle". De la Nature des Dieux, livre II, p. 295.

${ }^{19}$ Cícero - De Natura Deorum (De la Nature des Dieux, p. 295), tradução do autor.

${ }^{20}$ Segundo Estrabão (citado por GLACKEN, 1996) na realidade as diversas disposições de um país não estão predeterminadas, como não o está a diversidade de nações ou línguas; todas elas dependem das circunstâncias e da sorte. Artes, formas de governo e modos de vida brotam de certas fontes internas. Florescem sob qualquer clima em que possam estar situados; o clima tem sua influência e, em consequência, algumas peculiaridades se devem à natureza do país, mas também a educação do país cria suas particularidades e possibilidades de lidar com a natureza. Estrabão exemplifica sua tese afirmando que os babilônios ou os egípcios não são filósofos por natureza, mas sim, são em razão de suas instituições de educação. De maneira análoga, a excelência de cavalos, bois e outros animais não são apenas o resultado dos lugares nos quais habitam, mas também de como são criados.

${ }^{21}$ Para Lenoble (1969, p. 190), "se a afirmação de uma Natureza regida por leis havia permitido ao homem conquistar essa primeira forma de liberdade que consiste em instalar-se num conjunto, a Natureza antiga continuava a ser demasiado a deorum bominumque domina para o homem ousasse reivindicar perante ela um destino autónomo. Não evita submeter-se-lhe senão aceitando-a, não pensa ainda em transformá-la, muito menos em dominá-la."

22 "Al leer los cometarios de los autores antiguos sobre os cambios causados por el hombre en el medio físico, se tiene una doble impresión. Primero, que hay un reconocimiento del hombre como ser activo que se esfuerza y obtiene logros, pese a la aparente estabilidad que podría resultar de las dominantes influencias ambientales [...]; y segundo, que la naturaleza viviente que esos hombres observaron - y muchas veces amaron - era ya, como ahora sabemos, una naturaleza muy cambianda por el hombre". (GLACKEN, 1996, p. 136) 
${ }^{23}$ De acordo com o Gênesis (1:11;24;26), "Deus disse: 'Que a terra verdeje de verdura: ervas que dêem semente e árvores frutíferas que dêem sobre a terra, segundo sua espécie, frutos contendo sua semente' e assim se fez"; "Deus disse: 'Que a terra produza seres vivos segundo sua espécie: animais domésticos, répteis e feras segundo sua espécie' e assim se fez"; "Deus disse: Façamos o homem à nossa imagem, como nossa semelhança, e que eles dominem sobre os peixes do mar, as aves do céu, os animais domésticos, todas as feras e todos os répteis que rastejam sobre a terra."

${ }^{24}$ GLACKEN (1996).

${ }^{25}$ De acordo com Erigena (apud GLACKEN, 1996), encontra-se na natureza quatro divisões, sendo que se compreende a natureza pelo fato de que a natureza encerra em si mesma a racionalidade. Não conhecendo Deus, pode-se inferir pela ordem do mundo sensível e inteligível, que Ele existe, e é a causa de todas as outras coisas. Na primeira etapa, a natureza que cria e não é criada é Deus, como princípio de todas as coisas; na segunda, a natureza que é criada e cria é representada pelas ideias arquetípicas ou causas primordiais; na terceira, a natureza é criada e não é o mundo sensível, o mundo das aparências, a criação tal e qual conhecemos; na quarta, a natureza nem cria e nem é criada, representa o Deus Criador, que uma vez alcançado seu fim, está em repouso e parou de criar.

${ }^{26}$ GLACKEN (1996)

${ }^{27}$ Além disto, segundo Lenoble (1969, p. 187), "o homem, dizia o cristianismo, não se situa na natureza como um elemento num conjunto: não tem o seu lugar nela como as coisas têm o seu lugar; é transcendente em relação ao mundo físico; não pertence à Natureza, mas à Graça, que é sobrenatural; e, por conseguinte, se quer a todo o custo encontrar-lhe um lugar, existe apenas um, o primeiro, com a condição ainda de precisar de imediato que não nasceu da natureza e que é feito para nela permanecer".

28 "1Bendize, ó minha alma, ao Senhor! Senhor, meu Deus, como és grande! Tu te revestes de majestade e esplendor, 2envolto em um manto de luz; estendes o céu como um toldo 3e constrói tua morada acima das águas. Das nuvens fazes carruagem e andas sobre as asas do vento; 4dos ventos fazes teus mensageiros e do fogo flamejante, teus ministros. 5Quando assentaste a terra sobre suas bases, para que jamais vacilasse, 6como um manto a cobria o oceano e as águas mantinham-se sobre as montanhas. 7æ̀ tua ameaça recuaram; ao reboar do trovão precipitaram-se, 8saltando pelas montanhas, descendo pelos vales, para o lugar que lhes assinalaste. 9Impuseste-lhes um limite que não ultrapassassem, para não tornarem a cobrir a terra. 10Fazes jorrar as fontes nos vales: elas correm por entre os montes 11e dão de beber aos animais do campo; os asnos selvagens matam a sede, 12junto delas moram as aves do céu, cantando entre os ramos. 13Do alto de tuas moradas regas as montanhas, e a terra se sacia do fruto de tuas obras. 14fazes brotar a erva para o gado, as plantas que o homem cultiva, tirando da terra o alimento, 15o vinho que alegra o coração, o óleo que dá brilho às faces e o pão que reconforta o coração do homem. 16São exuberantes as árvores do Senhor, os cedros do Líbano, que ele plantou, 17 nos quais os pássaros se aninham e em cujos cimos a cegonha tem pousada. 18As altas montanhas pertencem às cabras montesas, os penhascos dão abrigo às marmotas. 19Fizeste a lua para marcar os tempos, e o sol conhece seu ocaso. 20Quando desdobras as trevas e se faz noite, rondam as feras da selva. 21Os leões rugem por alguma presa, reclamando de Deus o alimento; 22ao nascer do sol recolhem-se e vão deitar-se nos covis. 230 homem sai para seu trabalho, para suas lides até o entardecer. 24Quão numerosas são tuas obras, Senhor, Fizeste-as todas com sabedoria! A terra está repleta de tuas criaturas. 25Eis o mar, intenso e vasto, por todas as direções: um fervilhar de animais, pequenos e grandes! 26Por eles singram os navios e o Leviatã, que formaste para nele folgar. 27Todos esperam em ti, que lhes dês o alimento no devido tempo. 28Tu lhes dás e eles o recolhem; abres a mão e saciamse de dádivas. 29Escondes a face e estremecem; se retiras o seu alento, morrem e voltam ao pó. 30Envias o teu alento e são recriados e renovas a face da terra. 31Perdure sempre a glória do Senhor! Alegre-se o Senhor por suas obras!32Ele olha a terra e ela treme; ele toca as montanhas e elas fumegam. 33Enquanto eu viver, cantarei ao Senhor; celebrarei meu Deus enquanto eu existir. 34Seja-lhe agradá- 
vel meu poema, e eu me alegrarei no Senhor. 35Desapareçam da terra os pecadores, e os ímpios não mais existam! Bendize, ó minha alma, ao Senhor! Aleluia!" (http://www.ecclesia.com.br/biblioteca/ liturgia/quinta_feira_santa.htm)

${ }^{29}$ Detalhando mais suas ideias em De natura locorum, Aberto Magno escreve que as pessoas nascidas nos lugares mais quentes são elas mesmas mais quentes, enrugadas como sementes de pimenta devido a excessiva secura. A cor negra da pele, exemplificada pelos etíopes, explica-se pelo seguinte modo: o ventre quente e seco recebe sêmen quente; o líquido mais sensível do sêmen seca até consumir-se, e o mais denso que subsiste produz a negrura da pele. Seus corpos secos, rodeados de ar muito quente, perdem continuamente água. Essas pessoas são muito ligeiras e ágeis; tem pouco medo da febre. O calor extrai delas toda a umidade, de modo que suas partes privadas são débeis e estéreis. O espírito da vida escapa com a umidade, e vivem somente até os trinta anos. [...] Os nativos deste clima (klima) quente e seco que passam a viver no quarto ou no quinto clima (temperado), podem passar da cor negra à branca (MAGNO apud GLACKEN, 1996)

30 Segundo Filón (Sobre a Criação, apud GLACKEN, 1996), a prova mais clara do domínio do homem está sob os olhos. Às vezes, um número muito grande de gado é conduzido por um único homem sem grandes ferramentas ou vestimentas especiais. Já os animais com toda a força, equipados pela natureza para sua autodefesa, se humilham [são dominados] pelo homem que porta apenas seu bastão, são dominados como os escravos ante seu senhor, e acatam suas ordens.

${ }^{31}$ RECLUS (1886). 



\section{IV - O HOMEM E A NATUREZA}

\section{O PERÍODO DOS DESCOBRIMENTOS}

Descobrimentos de novas naturezas e novos homens

Conhecer é Fabricar

A sistematização da Geografia

O início de um período novo sempre traz consigo algumas marcas do período anterior. A mudança, por mais brusca que seja, nunca apaga por completo os vestígios do momento histórico precedente. Assim, segundo Glacken (1996), as ideias sobre as causas finais ou desígnio da natureza, uma teleologia da natureza, também floresceram nos tempos modernos. Absorveram novas provas, novos pontos de partida, novas terras, novos descobrimentos astronômicos e novas interpretações biológicas, com a penetração na estrutura da matéria orgânica e inorgânica por meio do microscópio.

Uma ilustração que materializa estas novas concepções da natureza vinculada à astronomia, é a figura O Homem e a Terra, encontrada no livro de Camille Flammarion, que mostra uma nova relação do Homem com a Natureza influenciada pelos novos sistemas de ideias do Renascimento e da Idade Moderna, onde o temor a Deus é substituído pela crença na ciência. O homem da referida gravura está "espiando" o que há fora da atmosfera terrestre, encontrando uma engrenagem e não um monstro ou Deus.

Nesta direção, para Lenoble (1969), a criação da Natureza no Ocidente colocará um fato novo na sua interpretação, o desenvolvimento da ciência, das teorias e a mudança na ideia de natureza. Segundo o autor (op.cit., p.79), 
o nascimento da Natureza ocidental, coloca-nos imediatamente perante o facto tão afrontosamente negado pelo empirismo de que, pelo menos em certas circunstâncias, a reforma da consciência precede a da ciência, como se então a Natureza do físico utilizasse simplesmente uma imagem da natureza já concebida, capaz de se actualizar no pensamento e na arte.

O Período dos Descobrimentos não se define apenas pelo descobrimento de novas terras - a América e, posteriormente, a Oceania - mas também pelos descobrimentos da ciência e da técnica, que trouxeram grandes contribuições para o entendimento que os homens fazem da natureza no período atual. Este novo período também significou uma inversão na posição entre o homem e a natureza ${ }^{32}$.

\section{O INÍCIO DO PERÍODO DOS DESCOBRIMENTOS}

Como marco inicial do Período dos Descobrimentos tem-se as Grandes Navegações, do ponto de vista geográfico; e o Renascimento, no campo filosófico, sendo os clássicos gregos e romanos as fontes de inspiração.

De acordo com Glacken (1996), a maioria dos grandes nomes do começo da ciência moderna não negava os desígnios na natureza nem a validade das causas finais. Copérnico, Galileu e Kepler, grandes nomes da ciência e da filosofia, apesar das críticas, mantiveram vivo o espírito da teleologia e da ideia de desígnio na natureza ${ }^{33}$.

$\mathrm{Na}$ mudança de perspectiva no entendimento da natureza, era fundamental, a partir da interpretação de Lenoble (1969), uma transformação da ideia de finalidade e espontaneidade nos ciclos e elementos da natureza. Era uma necessidade para os mecanicistas que a natureza fosse considerada uma máquina/mecanismo ${ }^{34}$, e para isto retomaram antigas ideias clássicas, como da natureza matemática da Natureza. Ao pensar a Natureza como máquina, a ciência se torna a técnica para exploração e entendimento da máquina, do seu funcionamento e da sua reprodução.

O conhecimento mecanicista da natureza partia da premissa atomista da quebra do todo em partes, as quais eram passíveis de serem compreendidas por leis científicas específicas, que dão suporte a montagem da explicação do todo. O todo é o resultado da soma das partes entendidas isoladamente.

Outra corrente, presente neste momento histórico, era a Organicista, que partia do entendimento do todo, como forma de explicação da partes, uma vez que a finalidade ou desígnio do todo está presente nas ações e reações das partes ${ }^{35}$. 
Entretanto, tanto a vertente mecanicista quanto a organicista, convergiram para uma ideia em comum, a ruptura com a ideia de envelhecimento da natureza e sua consequente fraqueza, razão pela qual o homem impunha sua superioridade. Se para alguns, a natureza como uma engrenagem já possuiu mais força nos tempos passados, para outros sua debilidade era consequência de sua "idade mais avançada". Assim, cabia ao homem através de sua cultura, arte e ciência reparar as ruínas da natureza ou provar que as doutrinas de envelhecimento da natureza não eram mais do que interpretações a serem superadas.

Se a ciência moderna ocupou seus primeiros anos para refutar a ideia de uma natureza que envelhecia e para provar uma constância na natureza (manutenção de uma quantidade natural), esta negação da deterioração "natural" da natureza será um importante dado teórico para a ideia de seu uso inesgotável da natureza e de seus recursos pelo modo de produção capitalista, quando este se tornar o motor do mundo moderno e contemporâneo ${ }^{36}$. Para Glacken (1996), a negação de uma deterioração da natureza era também uma crença afirmativa. ${ }^{37}$

Para John Ray (The wisdon of God manifested in the works of the creation, publicado originalmente em 1692, citado por GLACKEN, 1996), a terra e a natureza foram criadas da mesma maneira como estão hoje, mas seu aspecto exterior pode variar em função de forças naturais ou humanas. Glacken (1996) observa que seu pensamento era uma forma de união entre uma doutrina das causas finais (o desígnio da Criação) e a influência da ciência e tecnologia humanas. Para o autor (op. cit.) a importância da obra de Ray reside no fato de sua rechaça a crença do esgotamento e da dissolução do mundo, isto posto sobre bases filosóficas, religiosas e científicas; suas objeções também residiam nas observações do estado atual da natureza, em linhas similares as do uniformitarismo desenvolvido na geologia no século XIX. Na natureza, dizia Ray, não há nada que manifeste ou permita inferir uma futura dissolução, se bem que alguns acidentes pouco prováveis (dilúvios, extinção do sol, erupção de um fogo central encontrado na terra, a secura ou a disposição inflamável da terra na Zona Tórrida, que poderia ser incendiada por vulcões ou uma erupção simultânea de todos estes) poderiam arruinar a Terra $^{38}$.

A visão otimista de Ray em relação ao homem como um agente melhorador da natureza, em uma construção próxima àquela de Willian Moris Davis ${ }^{39}$ escreveria no século XIX, era baseada na crença do desenvolvimento tecnológico que a sociedade moderna estava experimentando neste Período dos Descobrimentos. O desenvolvimento iria melhorar a relação harmoniosa entre o homem e a natureza. Observa-se o deleite de John Ray com a beleza estética da natureza, quando proclama a 
diversidade que se distingue na superfície da Terra, na forma de colina, vales e as altas montanhas, que oferecem agradáveis panoramas! Quão cuidadosamente vestidos e adornados com a graça do verde das ervas e das árvores majestosas, dispersas e isoladas ou reunidas em bosques e arvoredos, e todos embelecidos com elegantes flores e frutos! ${ }^{40}$

O desenvolvimento da consciência do controle da natureza será crucial para o entendimento das ideias e conceitos de natureza no período atual. Seu aperfeiçoamento está baseado na aplicação da ciência teorética à ciência aplicada e da tecnologia aos novos usos e demandas dos recursos naturais que o Período dos Descobrimentos impôs e ao mesmo tempo possibilitou aos homens.

A tomada de consciência do controle da natureza pelo homem, desde o Renascimento até o século XVIII tem, segundo Glacken (1996), duas perspectivas ${ }^{41}$ :

1) A primeira procede da ciência teórica, teologia ou filosofia, e põe em relevo o papel do homem como o modificador ou o controlador da natureza, como função decorrente de sua posição na escala dos seres e sua capacidade única, inteligência, para interpretar o significado da criação.

2) A segunda é oriunda das observações cotidianas, sem filosofia nem moralizações. Muitas vezes fruto de divagações em torno de assuntos técnicos, de mineração, irrigação ou maquinismo.

\section{CONHECER, EXPERIMENTAR, REPRODUZIR E FABRICAR A NATUREZA}

O homem não só toma consciência de sua força modificadora da natureza como também dissocia desta ação o pecado ou a audácia de imitar ao Criador. O homem como inventor, experimentador, curioso, inquieto, ativo na habilidade mental e manual, cria formas para dar um sentido lógico/científico à natureza.

Ao longo dos séculos XVII e XVIII cresce o entendimento de que o homem acumula conhecimentos que o conduz a um incremento de seu controle da natureza, através do aumento das áreas de cultivo, como uma grande contribuição das artes, ciências e técnicas. Isto se deve muito também às contribuições de Francis Bacon, Descartes e Leibniz, que acreditavam no poder do conhecimento para controlar a natureza e eram "entusiastas da tecnologia" aplicada na melhoria da vida e da condição humana. 
Segundo Glacken (1996), o espírito de Francis Bacon e Descartes e, de seus percussores, Leonardo da Vinci, Paracelso, Agrícola e Palissy, permaneceu presente em muitas ideias e pensamentos no século XVII, na busca por demonstrar o crescente controle da natureza pela ciência, assim como pelas artes, esta em um patamar "racional" superior da experiência humana. Já para Lenoble (1969, p.192), "no século XVII, Bacon e Descartes ousam tornar-se "donos e senhores da Natureza", fazem-no proclamando que obtêm de Deus este domínio e esta posse". Posse de uma natureza-coisa, sem alma, de um "mecanismo para triturar os homens e as almas".

Segundo Francis Bacon, na obra Novum Organun, "o império do homem sobre as coisas se apóia unicamente nas artes e nas ciências. A natureza não se domina, senão obedecendo-lhe". (AFORISMO, 129). Na conclusão de Novum Organum (1999, p. 218), ainda faz um elogio à nova posição do homem sobre a natureza, uma retomada de seu lugar de destaque dentro da criação divina, a retomada do direito e domínio da natureza, direito esse que havia perdido pela Queda do paraíso e que agora, pela ciência, resgatava o desejo de Deus. "Pelo pecado o homem perdeu a inocência e o domínio das criaturas. Ambas as perdas podem ser reparadas, mesmo que em parte, ainda nesta vida; a primeira com a religião e com a fé; a segunda com as artes e com as ciências."

Já Matthew Hale, (The primitive Origination of Mankind, apud Glaclen, 1996), assume uma posição altamente legalista e moral perante as relações do homem com a natureza. Segundo o autor, o homem se assume como senhor da terra e por este motivo possui obrigações legais para com esta, em função em virtude de sua inteligência e suas habilidades manuais. A Terra necessitada de uma natureza superior (homem) para a manutenção de sua ordem, deixando-se modificar por este homem, que tem como objetivo maior, as ações em proveito de si próprio. Segundo Glacken (1996), os homens intervêm ativamente na natureza primitiva ou bruta, com o fim de manter sua civilização. Já a natureza não tocada pelo homem é uma natureza de características inferiores. Cabe ao homem a função de ser o guardião da natureza, um administrador indicado por Deus, em sua relação com os outros constituintes da vida natural. Sua relação com esta natureza, colocada sob suas asas, é definida pela sua posição superior num podium "natural", bem como pelas suas conquistas tecnológicas em vários ramos da engenharia civil além de outras atividades não tão revolucionárias, mas que num processo cumulativo produzem profundas transformações na paisagem e na natureza.

Cabe, neste momento, fazer uma menção especial à mudança no território empreendida na Holanda, um lugar onde o homem se impôs sobre uma natureza muito hostil e construiu uma nação desenvolvida. As transformações na Holanda 
foram importantes para moldar e exemplificar os pensamentos sobre a ação do homem na natureza.

Primeiramente, cabe ressaltar as transformações espetaculares que os holandeses fizeram no seu território mediante a construção de diques que culminaram na obtenção de novas terras férteis (polders) em detrimento da perda de área marinha. Depois do ano 1600, os moinhos de vento se converteram em ativas bombas de água em grande escala [...] Na península ao norte de Amsterdã havia sido encontrado até 1640 até 27 lagos drenados pelo bombeamento. O mesmo havia sido proposto para drenar o Halemmermeer com a ajuda de 170 moinhos de vento ${ }^{42}$.

Os dois primeiros séculos do Período dos Descobrimentos foram decisivos na cristalização da ideia do homem como controlador e dominador da natureza, iniciado com a ideia religiosa do homem como administrador de Deus (pensamento conectado com a Idade Média), mas que aos poucos vai sendo alterado pela ideia de homem possuidor de uma superioridade natural e divina. Este fato, acrescido às inovações técnicas, coloca o homem no papel de criador, lugar até então reservado a Deus. O papel fundamental das transformações na Holanda está baseado na crença de que o homem, através de suas ferramentas e conhecimentos, estava melhorando a natureza de maneira tão decisiva e segura, que a aceitação de seu controle era praticamente inevitável.

De acordo com Marsh (1965) o homem tem transportado plantas de um habitat nativo para novas terras, tem introduzido uma nova força geográfica para agir sobre a natureza, e isto, geralmente, às custas de espécies endógenas ${ }^{43}$, as quais são suplantadas pela vegetação estrangeira. As novas e velhas plantas são raramente equivalentes entre si, e a substituição por uma planta exótica, de uma árvore, arbusto ou grama, aumenta ou diminui a importância relativa da vegetação como elemento na geografia do país dos quais elas são removidas ${ }^{44}$.

Este significativo aumento da concepção do homem como modificador na natureza terá maior desenvolvimento ainda no século XVIII, com contribuições de filósofos, biólogos e historiadores naturais, e muitos destes com grandes vínculos com a Geografia, como Kant, bem como dos próprios geógrafos, a partir dos finais do século XVIII.

Emmanuel Kant, filósofo fundamental na estruturação do pensamento geográfico, de acordo com Glacken (1996), na Crítica ao Juízo Teleológico, afirma que a natureza insere no mundo um sistema de constante formação de novas terras, com deposição de sedimentos nos litorais e desembocaduras fluviais. O questionamento kantiano reside na busca pela explicitação do valor destas transformações para a própria natureza, uma vez que tais depósitos, que aterram áreas marinhas e possibilitam o assentamento e usos humanos, só teriam benefícios quando inseridos no contexto social. Para a natureza em si, o ganho de vida na terra signi- 
fica a mesma proporção de perda de vida no mar. Ou seja, para a natureza pouco importa de que forma sua manifestação vital se concretiza no sistema natural.

Para Engels (1991), Kant ${ }^{45}$ instituiu a ideia da Terra possuidora de história, cuja constituição estava sendo formada paulatinamente, derrubando a ideia de "invariabilidade absoluta da natureza”. A Terra, com história, passa por sucessões de tempos e espaços, inserindo a ideia nascente de uma natureza que não é estática, que não é uma realidade atual congelada. A natureza aparece como uma construção e com movimentos que lhe garantia uma constante transformação e uma constituição sempre provisória.

As explicações da natureza com caráter fisicoteológico perdem sua força e posição de destaque no sistema de ideias do período. Um novo sistema, que coloca o estudo da natureza em função da vida política, econômica, social e cultural humana, bem como do estudo da natureza em função de si mesma, emergirá e ganhará terreno - o naturalismo.

\section{A NATUREZA ORGANICISTA}

O século XVIII também será o berço de outras ideias e concepções de natureza. O naturalismo tem como grande idealizador Goethe, o qual influenciará todo o movimento naturalista alemão com ideias de uma natureza romântica e chegará ao berço da geografia através de Humboltd. Para Goethe, na obra Comentário sobre a Natureza, o homem valoriza mais, em si mesmo e nos outros, aqueles processos que são intencionais e propositais. Busca intenções e propósitos na Natureza, porque seu conceito sobre esta não pode ir mais além do que o conceito que ele tem formado sobre si mesmo ${ }^{46}$. O homem ao enquadrar todas as coisas, inclusive a natureza, num sistema de referências a si próprio, obriga-se a supor que todas as formas externas a ele estão determinadas pelo seu sistema de pensamento. A partir deste pressuposto, o mundo dos seres viventes e da natureza torna-se inteligível.

As concepções naturalistas ${ }^{47}$ colocam o homem como um ser dentro da natureza. O homem necessita da natureza para sua sobrevivência, como, por exemplo, a necessidade natural de se respirar oxigênio e de se alimentar. O homem surge como um intruso no seio da natureza, mas suas habilidades o fazem assumir uma posição confortável num mundo natural. Caberia a inteligência humana empreitar uma busca por uma "vida harmônica" com a natureza.

As ideias naturalistas conforme já foram mencionadas influenciarão o nascimento da Geografia como uma disciplina sistematizada, pelas mãos de Alexander von Humboltd ${ }^{48}$. Os Quadros da Natureza remetem a uma forma ou procedimento 
de estudo da natureza baseado na observação, lembrando uma retomada do ideal da contemplação no pensamento clássico. Na obra Cosmos, Humboltd revela todo seu interesse pela estética da natureza e beleza da paisagem, como fontes de prazer intelectual e moral oriundo de sua observação. As viagens e "conquistas" do Capitão Cook, no Pacífico Sul, tendo como relatores George Forster e Johann Reinhold Forster, foram, segundo Glacken (1996), fonte de inspiração importantíssima para Humboltd em sua busca pelo entendimento da natureza em sua máxima extensão, a Terra ${ }^{49}$.

Outro marco das ideias naturalistas, vinculado ao movimento Romântico, segundo Lenoble (1969), é a nascente substituição do modelo de jardim italiano ou francês, ordenado e geometrizado, pelo modelo do jardim inglês, onde a natureza manteria sua liberdade. O jardim inglês busca uma imitação da natureza, com grutas e cascatas, onde tudo é feito para copiar e conferir-lhe uma proximidade com uma natureza primitiva e pitoresca. As questões referentes aos jardins formais e jardins ingleses serão retomadas e aprofundadas posteriormente quando se tratar das especificidades da natureza na cidade.

\section{A ÉPOCA DO HOMEM NA HISTÓRIA DA NATUREZA}

Se durante milhões de anos a natureza reinou absoluta no controle da vida na Terra, as contribuições dos pensadores clássicos, renegada ou retrabalhada durante o Período Teológico e, resgatada no Período dos Descobrimentos, foram decisivas para se colocar em xeque a influência da natureza na vida humana e para delimitar a passagem para um momento de certo equilíbrio entre o homem e natureza, com uma vantagem humana, no que concerne ao controle dos processos que movem este mundo.

Considera-se de fundamental importância a contribuição que o Conde Buffon deu ao entendimento da visão sobre uma natureza humanizada, construída a partir de uma perspectiva política, econômica, cultural ou social. Desta forma, cabe aqui fazer um destaque de suas ideias em duas obras Histoire Naturelle e Des Époques de la Nature.

Buffon é claramente influenciado pelas ideias de Cícero (trabalhadas anteriormente), quanto à superioridade do homem na natureza, fruto de sua inteligência, habilidade (técnicas) e, principalmente, pelo uso consciente de suas mãos. Buffon faz o elogio da ação humana sobre a natureza, mas com a preocupação de que a sociedade, como um todo, se beneficiasse desta ação e incorporação da natureza. Resgata-se aqui a ideia da Emancipação Coletiva. 
Buffon $^{50}$, segundo Glacken (1996), não aceitava muito bem os ideais românticos sobre a natureza. Para ele, o homem tem um imenso poder para transformar a natureza, tendo uma grande crença nas tecnologias e nas possibilidades de melhora para o indivíduo e para a sociedade. Partidário do estudo da natureza através de sua história, Buffon vê a natureza como um sistema de leis estabelecidas pelo Criador, cuja função é dar existência às coisas e aos seres em sua contínua sucessão. Entretanto, a natureza não é meramente uma coisa nem um ser, pois desta forma seria o próprio Deus. A natureza pode ser considerada como um poder vivo e gigantesco, que preenche e anima todas as coisas.

O homem, para Buffon, de acordo com Glacken (1996), está na ordem dos animais, mas é completamente diferente deles. Está na natureza, mas de uma outra forma. Enquanto os animais vivem da repetição de seus instintos, vivendo uma sucessão dos mesmos padrões, o homem, pela sua inteligência, razão e capacidade de falar, criar e julgar se diferencia. O homem é o ser superior entre os seres viventes.

Buffon (Histoire Naturelle) considera a natureza selvagem como algo horrível e letal, sendo função do homem sua conversão em algo grato ou habitável, através das obras possíveis de transformação. Uma nova natureza salta de nossas mãos. Quão bela é esta Natureza cultivada! Que brilhante és e quão esplêndida, quando adornada pelos cuidados do homem! ${ }^{51}$

Em relação à ação do homem sobre a natureza, Buffon escreve que o homem é o mais nobre produto da natureza e a natureza penetrável para o homem, se multiplica sob seus cuidados de muitas e desejáveis maneiras. Flores, frutos e cereais, espécies de animais úteis têm sido transportadas, difundidas e incrementadas em grande medida; espécies inúteis têm sido eliminadas; a mineração tem progredido. As enxurradas têm sido contidas, os rios direcionados e controlados. O mar tem sido vencido. A terra tem sido restaurada e fertilizada. Os prados risonhos, os pastos, as vinhas e os hortos das colinas, cujos topos estão coroados por árvores úteis e bosques jovens; as grandes cidades que ocupam lugares antes desertos, os caminhos e comunicações são algumas manifestações de poder e de glória que mostram suficientemente que o homem, dono do domínio da Terra, tem mudado-a e renovado-a em toda sua superfície, sempre compartilhando este império com a natureza ${ }^{52}$.

O homem que multiplica animais e plantas, bem como muda suas distribuições, ao seu desejo e necessidade, que busca melhorar e controlar os climas para incrementar sua própria existência, age sobre a natureza natural ou sobre a primeira natureza, a qual era para Buffon, sem charme e, em certo sentido, macabra (visão 
contrária aos ideais românticos de uma natureza natural pitoresca). Nesta ação sobre a primeira natureza, o homem, através de sua ação, começa a criar ou produzir uma segunda natureza. E Buffon, em Les Époques de la Nature, mostra uma Sétima Época, um momento onde a primeira natureza passa a ser a segunda natureza. Segundo o autor (op. cit.), nesta Sétima Época, finalmente, toda a face que a Terra exibe o selo e a marca do poder do homem. Mesmo que subordinado ao poder da natureza, o homem tem feito muitas vezes mais que esta, ou ao menos tem ajudadoa tão maravilhosamente que, com a ajuda da mão humana, a Natureza tem se desenvolvido em toda a sua extensão e tem chegado gradualmente ao ponto de perfeição e magnificência ${ }^{53}$.

Com estas afirmações tão incisivas de Buffon sobre a ideia e o conceito de natureza, atrelados às atividades humanas, bem como suas contribuições na visão otimista da inserção da vida social num mundo natural, encontram-se as bases de sustentação para uma mudança de período.

No final do Período dos Descobrimentos, o homem, segundo Lenoble (1969, p. 316)

começa a agitar-se com tanto brio na conquista do mundo - a extensão cartesiana - que perde toda e qualquer preocupação. Deus e a alma continuam a ser os objetos da metafísica, mas rompeu-se a ligação entre a física e a metafísica, isto é, entre a Natureza e Deus. [...] A Natureza tornou-se objecto unicamente da ciência, isto é, segundo a acepção nova do termo, das técnicas. [...] A ciência torna-se o novo ídolo. Ela penetra os segredos da Natureza, como a psicologia positiva penetra os segredos da consciência.

Acrescenta-se a este plano das ideias, a Revolução Industrial e a transformação do mundo mercantilista agrícola num mundo capitalista industrial. O final do século XVIII representa o fim de um período das relações do homem com a natureza, em que se observa uma gradual mudança na posição de ambos no sistema de ideias, com a incipiente sobreposição da natureza pelo homem. O período seguinte irá aumentar esta diferenciação entre o homem e a natureza e, no âmbito das ideias, será contemplada uma dissociação mais acelerada com a teoria da evolução, a especialização das ciências e as grandes transformações da natureza. 


\section{O PERÍODO DA INCORPORAÇÃO}

O homem como agente de transformação

A incorporação da natureza

A natureza capitalizada

A terra fez o homem e o homem refez a terra incessantemente.

Élisée Reclus

Além das ideias desenvolvidas no período anterior e a crescente industrialização do mundo ocidental, no Período da Incorporação dois processos influenciaram fortemente as ideias e conceitos de natureza e são fundamentais até os dias atuais - o Higienismo e o Esteticismo.

O Higienismo é definido como o saneamento e a limpeza das cidades e da natureza, com um grande número de novas técnicas e tecnologias que foram criadas para dar suporte a este novo conceito de natureza limpa e padronizada. O Higienismo é marcado pela eliminação, principalmente, das "águas paradas" - sinônimos de estagnação - e dos brejos (no caso do Brasil, os mangues). Todo um aparato técnico surge com esta finalidade. Entretanto seu uso é determinado pelo poder econômico e, consequentemente, político, pois somente a nobreza e a burguesia têm acesso a estas técnicas. As classes mais pobres continuam vivendo em meio a uma Natureza hostil e insalubre.

O outro sistema de ideias, agindo concomitantemente com o Higienismo, é o Esteticismo. Neste sistema, a natureza, como sinônimo de paisagem, é passível de um julgamento estético de beleza, que também seguirá um padrão "civilizado" previamente definido. A natureza, cortada e delimitada em linhas retas, torna-se um jardim, um signo da administração humana. A natureza, como um padrão estético ${ }^{54}$ de beleza requintada e sofisticada, é cada vez mais valorizada e decorativa, sendo acrescida de objetos humanos - monumentos à história do homem - intervenções para torná-la cada vez mais grandiosa. A riqueza natural não basta, é preciso demarcar o território humano, sua conquista, sua incorporação e sua produção.

Esta visão estética está muito atrelada a uma visão romântica da natureza que será difundida pelos relatos de viajantes e pela produção de litogravuras. A Natureza se torna um elemento de consumo, um produto a ser vendido aos viajantes e depois, aos leitores e compradores de pinturas e gravuras. Como os elementos estéticos da Natureza são incorporados ao mundo do consumo, através de suas representações pictóricas, toma corpo, na Europa, a criação de formas de proteção das paisagens pitorescas, que garantam sua aparência "natural", passível de ser utilizada apenas como deleite estético contemplativo, evitando-se sua modificação 
visual. A representação romântica da natureza "selvagem" e escarpada estava na moda no final do século XIX, e a observação deste tipo de "natureza" era um dos programas preferidos das elites européias, que criaram vários Clubes de Turismo. Associações de Geografia elaboraram publicações especializadas. Também se encontra, neste momento, a demarcação dos primeiros parques naturais nacionais na Europa destinado a fins científicos e ao turismo burguês, com entrada reservada ${ }^{55}$. Nas cidades européias, o Esteticismo impulsionará, juntamente com o Higienismo, a criação de parques urbanos, mas socialmente diferenciados: Parques para operários (Buttes Chamont, em Paris, é um exemplo) e Parques para a aristocracia (Bois de Bologne, também em Paris).

\section{A INCORPORAÇÃO DA NATUREZA PELO TRABALHO DO HOMEM - KARL MARX}

O trabalho do homem é uma das formas de incorporação da natureza à vida social, configurando-se numa importante categoria na mediação entre a sociedade e a natureza, sendo fundamental na produção e reprodução da vida humana.

Marx será fundamental para se entender a contribuição da chamada geografia crítica para o tema tratado, bem como no entendimento dos usos e conteúdos que têm sido atribuídos à ideia de natureza no período atual.

De acordo com Schmidt (1976), não estão claras nas obras de Marx suas posições e ideias sobre a natureza. Segundo o autor (op.cit., p. 23), o Marx de O Capital, define a natureza como o material da vida humana - como aquilo que não é subjetivo, que não se dissolve nos modos de apropriação humana, o que é diretamente não idêntico ao homem no sentido ontológico ${ }^{56}$. A natureza se mantém em um plano abstrato. A natureza em seu conjunto é para Marx um substrato anexo à história, homogêneo, cuja resolução em uma dialética entre sujeito e objeto constitui o cerne da crítica marxista. A natureza é um momento da práxis humana e ao mesmo tempo a totalidade do que existe ${ }^{57}$.

Nas obras de Karl Marx, a natureza aparece como: matéria, natureza, substância natural, coisa natural, objetos externos sensíveis, terra, momentos existenciais, objetivos do trabalho e condições objetivas do trabalho ${ }^{58}$. A natureza também pode ser entendida como mercadoria. Segundo Marx, em O Capital (1980, p. 41), "a mercadoria é, antes de mais nada, um objeto externo, uma coisa que, por suas propriedades, satisfaz necessidades humanas, qual seja a natureza da origem delas, provenham do estômago ou da fantasia". Na mesma obra, ele ainda explica que "a mercadoria é misteriosa simplesmente por encobrir as características sociais do 
próprio trabalho dos homens [...]" (MARX, 1980, p. 81). Assim, a mercantilização da natureza na cidade contemporânea promove a substituição do processo de incorporação da natureza à vida social pela idealização de uma primeira natureza.

O trabalho como atividade humana se dá sobre uma base material, sobre um sólido que é a natureza.

Antes de tudo, o trabalho é um processo de que participa o homem e a natureza, processo em que o ser humano com sua própria ação impulsiona, regula e controla seu intercâmbio material com a natureza. Defronta-se com a natureza como uma de suas forças. Põe em movimento as forças naturais de seu corpo, braços e pernas, cabeça e mãos, a fim de apropriarse dos recursos da natureza, imprimindo-lhes forma útil à vida humana. Atuando assim sobre a natureza externa e modificando-a, ao mesmo tempo que modifica sua própria natureza. Desenvolve as potencialidades nela adormecidas e submete ao seu domínio o jogo das forças naturais. (MARX, 1980, p.202)

Nesta citação se encontra a relação dialética entre o homem e a natureza, na qual a modificação de um implica na modificação do outro.

Apesar desta equiparação entre homem e natureza, Marx sempre dará maior peso a participação do homem, aliás, é o homem o centro de sua análise e o fim de todo conhecimento e dominação da natureza pela ciência e pela técnica. Pode-se observar esta análise, nos Manuscritos Parisienses, onde Marx, segundo Schmidt (1976), afirma que a natureza tomada em forma abstrata, por si, fixada na separação com o homem, não é nada para o homem ${ }^{59}$. Para Marx, a natureza sem a mediação do trabalho, sem a presença e vida que lhe é conferida pelo homem, é, em si mesma, apenas um substrato material ${ }^{60}$.

A transformação que o homem opera na natureza, a produção de uma segunda natureza, é um processo dialético onde esta natureza transformada também pode retornar ao seu estado primitivo. De acordo com Schmidt (1976), a segunda natureza, artificial e humanizada, que aparece como uma construção do homem sobre uma base natural, sobre a natureza primeira, pode transformar-se novamente nesta, através de ciclos naturais que desintegram e que deterioram as substâncias, como o caso do ferro de automóveis ou outros objetos que oxida e retorna a sua "forma natural" ${ }^{\text {. }}$.

A modificação da natureza também será a responsável pela mudança na forma como seus elementos serão tratados, passando a se constituir em recursos naturais ${ }^{62}$. Ao mesmo tempo em que a natureza se insere na vida social do homem através do seu trabalho, ela se apresenta como uma condição da existência dos 
homens, vinculada às necessidades biológicas do corpo humano, uma vez que este é um corpo mortal.

Marx, em parceria com Engels, coloca-se radicalmente contra uma dissociação entre natureza e história [homem]. Na "Ideologia Alemã", colocam que Feurbach e Bruno Bauer se enganaram ao retirar da história a relação produtiva que os homens desenvolveram com a natureza. A natureza e a história não são para Marx e Engels, neste momento, duas coisas distintas e isoladas, pois os homens têm para si uma natureza histórica e uma história natural ${ }^{63}$. Continuando, afirmam ainda que a luta do homem contra a natureza, segue "até que as forças produtivas deste último se tenham desenvolvido sobre uma base adequada".

A natureza, mesmo que apresente condições, parece não impedir o progresso das ações humanas sobre a mesma. O trabalho penetra nas mais diversas esferas da natureza, em muitos casos enganando a nossa própria percepção.

Animais e plantas que costumamos considerar produtos da natureza são possivelmente não só produtos do trabalho do ano anterior, mas, em sua forma atual, produtos de uma transformação continuada, através de muitas gerações, realizada sob controle do homem e pelo seu trabalho (MARX, 1980, p. 206).

Além isto, numa crítica aos que ainda pregam uma natureza primitiva, romântica e idealizada, Marx \& Engels (1980), afirmam que o primado da natureza anterior não deixa existir, mas a natureza dos idealistas românticos não existe mais, salvo em alguns atóis na Austrália.

A ação do homem sobre a natureza é plena de intencionalidade, seguindo um objetivo e um projeto pré-definido. Segundo Marx (1980, p. 202), o homem, ao contrário dos animais, "não transforma apenas o material sobre o qual opera; ele imprime ao material o projeto que tinha conscientemente em mira, o qual constitui a lei determinante do seu modo de operar e ao qual tem que subordinar sua vontade" 64

Dentre estas intencionalidades encontram-se o desenvolvimento das técnicas e das máquinas que, como ferramentas ${ }^{65}$ ou instrumentais, são formas que o homem criou para aperfeiçoar seu processo de emancipação e libertação da natureza. Segundo Marx, em O Capital, a tecnologia mostra como se dá o comportamento do homem de maneira ativa sobre as condições colocadas pela natureza desde o processo inicial de produção da sua própria vida, bem como, nas relações sociais que ele desenvolve e também nas representações culturais e religiosas que surgem deste desenvolvimento técnico. 
Se nos primeiros momentos da história do homem, ele entrava em contato com a natureza somente através de seus órgãos sensitivos corporais, com o desenvolvimento da técnica, esta mediação passa a se constituir por instrumentos técnicos que surgem com a finalidade e objetivo previamente definidos e conscientes. Para Marx (1980 citando FRANKLIN), o homem é um tool-making animal (um animal fazedor de ferramentas), que se desenvolve a partir de sua mão e sua inteligência. "Na futura vida da humanidade, as forças brutas da natureza em acção nas máquinas serão os nossos escravos e servos.” (MARX, 1975, p. 113)

Além disto, o desenvolvimento técnico, os instrumentos artificiais da produção aumentam a intensidade e a extensão do domínio humano sobre a natureza, bem como inserem múltiplas formas de utilização da natureza, de seus recursos e objetos.

Entretanto, Marx (1980) alerta para o uso deste instrumental, numa sociedade marcada pela apropriação da natureza e do trabalho do homem pelas forças capitalistas, pois

a maquinaria, como instrumental que é, encurta o tempo de trabalho, facilita o trabalho, é uma vitória do homem sobre as forças naturais, aumenta a riqueza dos que realmente produzem, mas, com sua aplicação capitalista, gera resultados opostos: prolonga o tempo de trabalho, aumenta sua intensidade, escraviza o homem por meio das forças naturais, pauperiza os verdadeiros produtores. (MARX, 1980, p. 506)

Esta apropriação capitalista perverte a ideia de emancipação coletiva ${ }^{66}$ do homem, da rigidez colocada pela natureza, ela nega a solidariedade entre os homens e a cooperação possível na relação do homem com a natureza. A cooperação entre os homens, é entendida na concepção de Marx (1980, p. 374), como "a forma de trabalho em que muitos trabalham juntos, de acordo com um plano, no mesmo processo de produção ou em processos de produção diferentes, mas conexos".

Para Marx, no livro III de O Capital (1981, p. 942), a utopia na relação do homem com a natureza é o estabelecimento de um reino de Liberdade, de Emancipação Coletiva ${ }^{67}$.

O reino da liberdade só começa, de fato, onde cessa o trabalho que é determinado pela necessidade e por objetivos externos; por consequência, em virtude da sua natureza da coisa, encontra-se fora da esfera da produção material propriamente dita. Assim, como o selvagem tem de lutar com a natureza para 
satisfazer suas necessidades, para manter e reproduzir a vida, assim também deve fazê-lo o homem civilizado, em todas as formas de sociedade e sob todos os modos de produção possíveis. Com seu desenvolvimento, amplia-se este reino de necessidades naturais porque também se ampliam suas próprias necessidades, e também ao mesmo tempo se expandem as forças produtivas que as satisfazem. A liberdade, neste campo, só pode consistir no fato de a humanidade socializada, os produtores associados, regularem racionalmente seu intercâmbio orgânico com a natureza, submetendo-a ao seu controle, em vez de serem governados por ela como um poder cego e, cumprindo as sua tarefa com o menos dispêndio de energia possível e em condições tais que sejam próprias e dignas de seres humanos. No entanto, aqui encontramo-nos ainda no reino da necessidade.

Quando um projeto de homem egoísta e individualista substitui um projeto de emancipação coletiva, assiste-se a propagação de formas individuais de satisfação, um consumo individual que, para Marx (1980, p. 208), "gasta os produtos como meios de vida do indivíduo [...] o produto de consumo individual é, portanto, o próprio consumidor". Este consumo acaba criando uma relação fetichista entre mercadorias e objetos e, até mesmo, entre o homem e a natureza nesta sociedade de consumo individual. Um fetiche se dá numa forma de relação social definida e fantasmagórica entre as coisas. "Os produtos do cérebro humano parecem dotados de vida própria, figuras autônomas que mantêm relações entre si e entre os seres humanos". (MARX, 1980, p. 81)

Segundo a concepção de Marx (1980), o homem não pode apropriar-se da natureza de maneira individualizada, ela deve constituir-se num projeto coletivo.

\begin{abstract}
O homem isolado não pode atuar sobre a natureza, sem por em ação seu músculos sob o controle de seu cérebro. [...] O produto deixa de ser o resultado imediato da atividade do produtor individual para tornar-se produto social, comum, de um trabalhador coletivo, isto é, de uma combinação de trabalhadores, podendo ser direta ou indireta a participação de cada um deles na manipulação do objeto sobre que incide o trabalho. (MARX, 1980, p. 584)
\end{abstract}

De acordo com Marx, nos Manuscritos Parisienses (encontrado em SCHMIDT, 1976), o domínio da natureza não organizado numa forma socialmente justa, por maior que seja seu desenvolvimento, segue significando que se está à mercê da natureza. 
Num outro momento, Marx \& Engels (1980), escrevem como a economia capitalista ${ }^{68}$ abrangendo vários pontos do globo, tende a aniquilar as especificidades dos lugares e das relações mais próximas com a natureza, destituindo a emoção e o sentimento. Segundo os autores (op. cit., p. 74),

através da concorrência universal, constrangeu todos os indivíduos a uma tensão máxima da sua energia. Aniquilou o mais possível da ideologia, a religião, a moral etc. e sempre que isso não lhe era possível transformou-as em flagrantes mentiras. Foi ela que criou verdadeiramente a história mundial na medida em que fez depender do mundo inteiro cada nação civilizada e, para satisfação de suas necessidades, cada indivíduo dessa nação, destruindo o caráter exclusivo das diversas nações que era até então natural. Subordinou a ciência da natureza ao capital e retirou a divisão do trabalho a sua última aparência de fenômeno natural. Destruiu, na medida do possível, todos os elementos naturais no interior do trabalho e conseguiu dissolver todas as relações naturais para as transformar em relações monetárias. Em vez de cidades nascidas naturalmente, criou as grandes cidades industriais modernas que se desenvolveram como se se tratasse de cogumelos.

Outra questão trabalhada por Marx, com importante destaque na análise do entendimento que o homem faz da natureza no período atual, é o papel do consumo na sociedade capitalista. O consumo está em relação direta com a produção, uma vez que a produção também é consumo, consumo de energia ou de alguns produtos para produzir outros. "Toda produção é apropriação da natureza pelo indivíduo, no interior e por meio de uma determinada forma de sociedade". (MARX, 1999, p. 29)

Mais do que produzir um objeto, o processo produz também a necessidade de consumir este objeto e a forma como este objeto será consumido. Segundo Marx (1999, p. 32),

a fome é fome, mas a fome que satisfaz com carne cozida, que se come com faca ou garfo, é uma fome muito distinta da que devora carne crua, com unhas e dentes. A produção não produz, pois, unicamente o objeto do consumo, mas também o modo de consumo, ou seja, não só objetiva, como subjetivamente. Logo, a produção cria o consumidor. 
Complementa ainda (op.cit., p. 33), que

\begin{abstract}
a necessidade que sente desse objeto é criada pela percepção do mesmo. O objeto de arte, tal como qualquer outro produto, cria um público capaz de compreender a arte e de apreciar a beleza. Portanto, a produção não cria somente um objeto para o sujeito, mas também um sujeito para o objeto.
\end{abstract}

Estas contribuições de Marx serão fundamentais para se entender o consumo e a forma de consumo da natureza, seus objetos no período atual e os consumidores da natureza, concientes ou não de seus papéis como sujeitos na produção da natureza na cidade.

\title{
A DIALÉTICA DA NATUREZA - FRIEDRICH ENGELS
}

Após a exposição das contribuições de Marx, cabe fazer uma análise em algumas obras de Engels, as quais, em muitos pontos convergem diretamente para as concepções de Marx. No tocante à discussão das ideias de Natureza, esta assume uma importância muito maior nas obras de Engels, que se preocupou tanto com a história da interpretação da natureza, fazendo um acompanhamento das diferentes formas que foram sendo construídas ao longo da história das ideias, bem como com a proposição de uma forma revolucionária, nas suas palavras, para o entendimento e explicação da natureza - a dialética.

Inicia-se a abordagem sobre as ideias de Engels com o desenvolvimento do estudo da natureza. O grande destaque de suas interpretações é o processo histórico de diferenciação entre o homem e o animal, principalmente o macaco ${ }^{69}$. Segundo Engels (1990, p. 156) "os homens entram na história ainda meio animalizados e brutos, impotentes ainda, com relação às forças da natureza, ignorantes mesmo de suas próprias forças frágeis, como as próprias bestas e apenas mais produtivas do que elas". Usar as mãos foi o passo decisivo para a transição do macaco em homem, uma vez que foram as mãos, numa atividade racional, que criaram ferramentas e se articularam na forma de ferramenta.

O cérebro, os sentidos, o trabalho e a linguagem criaram os estímulos contínuos que diferenciaram definitivamente o homem do macaco. De acordo com Engels, no apêndice da Dialética da Natureza - A humanização do macaco pelo trabalho 
o domínio da Natureza, iniciado com o aperfeiçoamento da mão, com o trabalho, ampliava o raio de percepções do homem, a cada novo progresso. Nos objetos naturais, descobria ele constantemente outras qualidades até então desconhecidas. Por outro lado, o aperfeiçoamento do trabalho, contribuía para aproximar, cada vez mais, os membros da sociedade; para multiplicar os casos de ajuda mútua, de ação em comum, criando, em cada um, a consciência da utilidade dessa colaboração ${ }^{70}$.

Engels (1991) afirma ainda que o animal usa a natureza somente para consumir o que suas necessidades naturais determinam. Ao contrário, o homem passa a produzir os seus meios de subsistência, ampliando sua esfera de produção até atingir um grau que jamais seria observado na natureza. Uma águia pode enxergar muito mais distante do que o homem, mas isto não significa uma vantagem para a águia em comparação com o homem, uma vez que o olho humano vê as coisas muito melhor.

A utilização mais produtiva dos recursos que sua natureza biológica fornece, possibilitou ao homem aprender a desenvolver habilidades, que o permitiram espalhar-se por todo o planeta, de assentar-se sob os mais diversos climas, não especializando sua alimentação (como muitos animais fizeram), aumentando o seu raio de espraiamento. Somente o homem imprimiu seu selo sobre toda a Terra, de acordo com sua vontade ${ }^{71}$. Estas concepções de Engels não significam a tentativa de criar uma dissociação entre o homem e a natureza, pois o autor afirma que não se deve rejubilar por esta conquista, pois, muitas vezes, alguns resultados são imprevisíveis. Não se deve, segundo Engels (1991), dominar a natureza como um povo bárbaro que é estrangeiro a ela, mas sim conquistá-la através do conhecimento que foi historicamente construído de suas leis, lembrando que os homens não são exteriores à natureza [ou a natureza não é exterior ao homem]. É impossível manter uma posição de separação antinatural entre espírito e matéria, entre o homem e a natureza.

Dentro de uma concepção histórica da natureza, Engels (1991, p. 41), critica as várias concepções unilaterais que pregam somente as imposições que a natureza coloca ao homem e esquecem que

o homem também reage sobre a Natureza, transformado-a e criando para si novas condições de existência. Da natureza da Alemanha dos tempos em que os germanos dali emigraram, resta muitíssimo pouco. A superfície da terra, o clima, a vegetação, a fauna e os próprios seres humanos modificaram-se 
imensamente, e tudo isso devido à atividade humana; enquanto as modificações que se verificaram na natureza da Alemanha, no decurso do tempo, sem a interferência, são incalculavelmente pequenas.

Já a tomada de consciência da natureza ocorre num momento importante da história da humanidade, que é a constituição do modo capitalista de produção, cuja principal característica é a busca do lucro imediato sem preocupação com o desenrolar de suas ações. Como modo de produção que se estabelece em várias instâncias da sociedade, este imediatismo financeiro também será instituído nas relações e nas ações do homem sobre a natureza. Como cita Engels (1991, p. 226),

\footnotetext{
aos agricultores espanhóis, estabelecidos em Cuba, que queimaram as matas nas encostas das montanhas (tendo conseguido, com cinzas daí resultantes o adubo suficiente para uma só geração, para cafeeiros muito lucrativos), não lhes importava o fato de que, mais tarde, os aguaceiros tropicais provocassem a erosão das terras que, sem defesas vegetais, transformaram-se em rocha nua? Em face da Natureza, como em face da Sociedade, o modo atual de produção só leva em conta o êxito inicial e mais palpável; e, no entanto, muita gente se surpreende ainda pelo fato de que as consequências remotas das atividades assim orientadas sejam inteiramente diferentes e, quase sempre, contrárias ao objetivo visado.
}

\section{A INCORPORAÇÃO GEOGRÁFICA DA NATUREZA. A AÇÃO DO HOMEM E UMA NOVA GEOGRAFIA FÍSICA - GEORGE MARSH}

No prefácio de sua obra Man and Nature $^{72}$, de 1874, George Marsh mostra que a perspectiva geográfica de entendimento das ideias e conceitos de natureza é indicação do caráter e, aproximadamente, a extensão das mudanças produzidas pela ação humana nas condições físicas do globo. Isto pode ilustrar a doutrina na qual o homem é, em tipo e grau, um poder de ordem maior do que qualquer das outras formas de vida animada, as quais, como ele, são nutridas na mesa farta da natureza ${ }^{73}$.

Geograficamente, as ideias presentes tanto no pensamento de Marsh quanto de Elisée Reclus, foram intensamente permeadas pelas configurações territoriais da 
Holanda, e como já mencionado no capítulo anterior, o fato que mais motivava a visão otimista e humanizada da natureza era a expansão do território humano sobre o que era, até então, o império marinho.

Uma nova geografia da natureza, constituída pela transformação que o homem realiza na natureza, foi baseada primeiramente na observação e, posteriormente, na dominação dos processos naturais. As mudanças no entendimento e na própria materialidade da natureza são cada vez mais atribuídas aos progressos humanos nos campos das ciências e das técnicas. Segundo Marsh (1965), as modernas ambições da sociedade visam alcançar grandes conquistas da natureza física, seus projetos são corajosas empreitadas até agora desenvolvidas para a modificação da superfície geográfica.

A respeito das fantásticas modificações na natureza que estavam tomando conta da Europa e dos Estados Unidos no século XIX, Marsh (1965) escreveu que estas mudanças, para o bem ou para mal, não foram causadas por grandes revoluções naturais do globo, nem são, por algum meio, atribuídas inteiramente à ação ou inércia moral ou física das pessoas. Elas são produtos de forças conflitantes ou coincidentes, atuando através de uma longa série de gerações. [...] Elas são puramente resultados calculados e desejáveis de simples e familiares operações da agricultura e da vida social $^{74}$.

A questão do melhoramento da natureza deve ser tomada como finalidade da vida humana, trazendo consequências para os próprios homens. Muita energia deve ser investida para ampliar e eternizar as fontes de riqueza e beleza natural. Para Marsh (1965), a Terra não estava, em sua condição natural, completamente adaptada para o uso do homem, mas apenas para manter a vida selvagem animal e vegetal. Em certa medida, a transformação da superfície terrestre, da supressão do natural e simulação da artificialidade, modificada para dar lugar a produtivamente, tornou-se necessária. Mas, o homem tem, infelizmente, excedido esta medida ${ }^{75}$. Para o autor (op. cit.), a Terra foi dada para o homem apenas para usufruto, não para consumo.

A melhora que o homem imprime na natureza, seguindo um padrão do período anterior, é representada pelo reflorestamento de antigas áreas devastadas, controle das enxurradas, drenagem de brejos e lagos e fertilização de áreas com solos esgotados. Para Marsh (1965), estas conquistas são muito mais gloriosas que os triunfos de guerras, as quais infelizmente, são façanhas muito mais exaltadas para algumas sociedades.

A produção de uma natureza artificial deve muito ao avanço conquistado pela ciência e pela técnica, no que se refere a meteorologia e a previsão climática. Estas melhorias permitiram o controle e a prevenção contra algumas leis naturais, e foram fortes componentes no avanço da agricultura e da indústria. 
Desta forma, segundo Marsh (1874), o homem tem feito muito para revolucionar a superfície sólida do globo, para mudar a distribuição, as proporções e as características essenciais dos organismos que habitam as terras e as águas. Mas esta busca pelo domínio e adaptação da natureza tem lugar, primeiramente, na correção de "defeitos" ou imperfeições da natureza.

Como grande parte dos homens têm vivido nas áreas costeiras, além de terem aprendido a tirar do mar a fonte de alimento, o rápido incremento dos transportes marítimos, impulsionados pelo aumento das trocas comerciais entre os países, fez com que as áreas costeiras fossem o lugar das grandes modificações que representam a materialização de um ideal de natureza à serviço da vida humana. Como exemplo das importantes realizações humanas nas áreas costeiras pode-se citar:

- mudanças na linha de costa com aterros ou drenagens que permitem um ganho de terra, colocando as linhas costeiras sujeitas ao controle do poder humano;

- grandes obras que representam uma importante melhoria da linha de costa, como portos, docas e marinas que são, para Marsh (1874), as mais honráveis e memoráveis conquistas do homem sobre a natureza, uma vez que permitem um grande aumento do comércio, das trocas comerciais e mesmo da conquista de novas terras.

As consequências destas modificações na natureza devem ser consideradas não só em seu aspecto físico visível, mas também do ponto de vista simbólico ou moral, pois carregam consigo um forte e significativo componente ideológico. Estão completamente em consonância com um sistema de ideias produzido no momento sobre o homem e a natureza. Do ponto de vista simbólico, as obras de engenharia que modificaram a paisagem na Europa, tais como o quebra-mar de Cherbourg (França), a drenagem de terras que ainda se processava na Holanda e alguns pontos da Inglaterra, a canalização e os desvios dos rios que possibilitavam sua navegabilidade, associados às imensas obras portuárias, traziam para o cotidiano das pessoas novas formas de valorização do trabalho humano. Como força capaz de alterar os caprichos da natureza e cuja magnitude de ação era compatível com as obras que também no mundo antigo, como no Egito, significavam uma vitória da humanidade no domínio da natureza. Assim, tais obras eram a própria materialização de um sistema de ideias e de conceituação a respeito da natureza.

Outro grande impacto na forma de entendimento da natureza, oriundo de profundas modificações físicas da natureza foram os trabalhos de engenharia hidráulica, associados não só a expansão de áreas cultiváveis, mas também vincula- 
das às questões sanitárias e de saúde. De acordo com Marsh (1874), nas épocas recentes, operações com propósitos relacionados ao saneamento da natureza, têm assumido certa magnitude e têm trazido efeitos econômicos, sanitários e geográficos, os quais colocam estas operações num alto posto nos esforços do homem para melhorar as condições naturais do solo que ele ocupa ${ }^{76}$.

A respeito desta ação de domínio do homem sobre a natureza cabe transcrever uma afirmação de George Marsh quando este mostra como a natureza se rende ao controle das técnicas e da razão humana. Para Marsh (1874), os encontros do homem com a natureza ocorrem em campos onde a natureza é colocada em conflito com o homem (pode-se pensar fisicamente como do ponto de vista de seus interesses econômicos ou simbólicos). Num primeiro momento, ela resiste às tentativas humanas de interferência nas suas operações, mas a natureza, achando o homem o mais forte, submete-se a suas regras, e termina por contribuir para ajudá-lo a levantar os muros e algemas pelas quais ele ensaia confiná-la ${ }^{77}$.

Esta valorização do homem como um agente ativo no entendimento e modificação da natureza será influenciado pela publicação ainda nos finais do terceiro quarto do século XIX, até então muito recente, para Marsh e Reclus, do trabalho de um geólogo italiano de Milão chamado Stopanni, que afirma, pela primeira vez, que o homem é uma força dentro da natureza tão poderosa quanto às próprias forças naturais, muitas vezes, tomadas como as de maior magnitude. Para Stopanini, (1873 no Corso di Geologia, de acordo com uma citação extraída de MARSH, 1874), a criação do homem foi a introdução de um novo elemento na natureza, uma força inteiramente desconhecida nos primeiros períodos. Esta nova força telúrica pode ser comparada, em poder e universalidade, às grande forças da Terra ${ }^{78}$. E para Stopanini estes eram os indícios de uma Era Antropozóica.

$\mathrm{Na}$ abordagem deste trabalho, pautada pela busca de interpretações "otimistas" ou antropocêntricas das relações do homem com a natureza, chega-se a um momento onde, comparável à unicidade do pensamento no Período Teológico, será inserida uma componente que guiará praticamente todas as formas de interpretação da natureza, a economia. O mundo capitalista que emerge com extrema força neste momento, irá inserir a natureza num conjunto de atributos passíveis de serem capitalizados e comercializados.

Apesar de se considerar que no período denominado de Período da Dominação, a força humana estava se sobrepondo, de forma diferente e intensa à natureza, como resultado e resultante de um sistema de ideias e conceitos que permitiam esta dominação, tanto do ponto de vista filosófico, moral, religioso quanto técnico e econômico, ainda não representou o enquadramento definitivo da natureza à vida social humana. 


\section{O HOMEM, A TERRA E O SENTIMENTO DA NATUREZA - ÉLISÉE RECLUS}

A obra e o pensamento de Élisée Reclus são sem dúvida, uma das maiores influências sobre este trabalho e se constitui em um dos alicerces teóricos de sustentação das ideias e conceitos a respeito da geografia, do homem e da natureza.

A sua famosa afirmação no prefácio de L'Homme et la Terre, o homem é a natureza adquirindo consciência de si própria ('bomme est la nature prenant consicence d'elle même), coloca a questão da emancipação coletiva dos homens perante a natureza, que perpassa os valores morais, físicos, religiosos e culturais.

Em 1874, no mesmo ano em que George Marsh publica seu livro, Reclus publica o texto De l'action humaine sur la géographie physique. L'bomme et la nature' (Da ação humana sobre a geografia física. O homem e a natureza). Neste texto, Reclus (2002, p. 34) afirma que o homem é a alma da Terra ${ }^{79}$. O autor continua ainda dizendo que à medida que as pessoas desenvolveram sua inteligência e sua liberdade elas passaram a reagir sobre a natureza exterior, não sendo mais passivamente subjugada. Decorrente desta transformação, os homens poderiam ser considerados como verdadeiros agentes geológicos, uma vez que, transformaram de diversas maneiras a superfície dos continentes, mudaram a economia das águas correntes e também modificaram os climas.

A ação humana consciente imprimiu na superfície do planeta uma diversidade de aspectos muito maior que as forças inconscientes da natureza. Além de sua superioridade na ação, o homem pode melhorar seu domínio, seu território, ajudando obstinadamente a terra no seu lugar a se embelezar. O homem digno de sua missão assume uma parte da responsabilidade na harmonia e na beleza da natureza em seu entorno ${ }^{80}$.

Os exemplos desta ação do homem sobre a natureza, de sua vontade perseverante, são as obras de drenagem que garantem a fertilidade da terra; transferências de elementos da flora e da fauna; a irrigação que permite a criação de novos oásis, os diques na França e os polders na Holanda. Estas obras úteis, que constituem em verdadeiras revoluções geográficas e que mudam o aspecto da Terra.

No texto, Géographie Général' (Geografia Geral), de 1872, Reclus coloca de maneira incisiva que estudar a superfície da Terra é necessariamente realizar um estudo da humanidade ${ }^{81}$, uma ideia muito próxima daquelas trabalhadas por Marx. A concepção de Reclus Telle terre, tel peuple (Tal terra, tal povo), não representava uma visão determinista do ambiente, mesmo quando os homens primitivos moldaram o seu modo de vida dentro de uma dependência absoluta da natureza (nas áreas costeiras os homens pescavam e nas áreas florestadas caçavam). Desde o princípio, os 
homens aprenderam a superar as condições e limitações que a natureza local colocava. Com estas mudanças no meio, decorrência da revolta do homem contra as duras necessidades, começa a geografia propriamente dita ${ }^{82}$.

Na Leçon D'overture du cours de Géographie Comparée dans l'espace et dans le temps (Lição de abertura do curso de Geografia Comparada no espaço e no tempo), de 1894, Reclus explicita ainda mais uma "ideia materialista", a Terra fez o homem e o homem refez a Terra incessantemente ${ }^{83}$. A tomada de consciência pelo homem é originada de sua própria relação com a natureza, como um meio primitivo, que segundo Reclus (1985, p. 57), sendo "constituído pelas coisas circundantes, é apenas uma tênue parte do conjunto das influências às quais o homem está sujeito". Este meio primitivo, como algo estático, não se coloca como entidade física, como obstáculo ao homem, mas sim como o que enriquecerá a humanidade e possibilitará sua emancipação. A atividade intelectual, que se deu sobre esta natureza, atribui uma dinâmica dada pela própria sociedade. É o papel do homem de transformar a natureza em geografia, pois a humanidade não apenas habita a superfície da Terra, mas a ocupa em todas as suas possibilidades. A humanidade floresce sobre ela e a consome em todos os sentidos.

Reclus considera a natureza como uma mãe beneficente que nutre e alimenta seus filhos, mas sem o ideal romântico de harmonia, pois até as plantas e os animais lutam por seu território. Assim, não seria diferente para o homem que, segundo Reclus (1886), está incessantemente em conflito com a natureza, seu habitat. Tendo sido, durante sua infância, submetido à natureza, uma época de primitivo barbarismo, o homem tem gradualmente emancipado a si mesmo, a partir de esforços para adaptar as forças da Terra para o seu uso [...] Por um longo período, os homens eram nada mais do que produtos inconscientes da natureza, mas paulatinamente tornaram-se agentes ativos sobre a história da natureza ${ }^{84}$. O homem tem feito seu, o solo da Terra através da ciência, quando começou a adaptá-la para seu uso através do cultivo ${ }^{85}$.

A incorporação e até produção de terras eram fatos que permeavam todo o sistema de ideias do século XIX, tendo como principal exemplo de análise a Holanda. A interpretação que Reclus contrói sobre esta conquista do homem é extremamente interessante.

Reclus (2002) escreve que a Holanda mostra os magníficos trabalhos do homem, e declara suas vantagens sobre a natureza. A história agrícola dos Países Baixos é escrita num combate sem trégua entre o homem e o oceano. Este combate relata a vitória do homem ${ }^{86}$. As terras reclamadas através da drenagem e da construção de diques na Holanda, uma nação inteira, nas palavras de Reclus (1886), em conflito com a natureza, se deu em duas etapas, com características muito particulares, definindo muito bem dois padrões de ideias em relação à natureza. 
A primeira etapa da produção das terras, reclamadas do mar, se deu através da construção de diques, canais e drenagens que seguiam os cursos dos pequenos corpos d'água. Desta forma, de acordo com Reclus (1886), as primeiras técnicas usadas na "construção" das novas terras eram ainda muito primitivas e muito próximas da natureza. Como consequência, as terras produzidas a partir destas técnicas, mostravam linhas meandrantes e pitorescas que muito as aproximavam de terras "naturais". As terras produzidas não eram tão destoantes das outras ao seu entorno.

Já a segunda etapa na conquista de terras, está vinculada a processos de drenagem e técnicas para a construção de diques mais avançadas. Estas terras produzidas, de acordo com um padrão mais avançado, introduziram um novo aspecto a paisagem: uma regularidade matemática, uma natureza geometrizada, com intervalos regulares entre canais paralelos e ângulos retos. Para Reclus (1886), a estupenda regularidade não é perturbada, salvo por massas de prédios em grandes cidades, pelos parques que as cercam e pelas estradas e ferrovias, que cortam os canais em oblíquas direções como se emergissem das cidades ${ }^{87}$.

A passagem sobre os obstáculos naturais, usando a palavras de Reclus (1886), ocorre a partir do conhecimento do mal, permitindo-se assim descobrir o remédio ${ }^{88}$. Além disto, as ideias trocadas por povos de todos os climas tornam-se patrimônio comum para todos. A inteligência criativa dos trabalhadores tem sido permitida, desenvolvida e aumentada ${ }^{89}$.

Além das ideias, os produtos e as pessoas começam também a se movimentar entre os lugares, levando a um aumento da conexão entre países. Os modos de comunicação ficam mais eficientes e passam a ser mais utilizados. Para Reclus (1886), os telégrafos elétricos representam uma liberdade física para o homem; sua liberdade é posta livre de obstáculos impostos pelo tempo e espaço. O homem torna-se pessoalmente presente em todos os pontos do espaço, através dos cabos que conduzem e trazem seus pensamentos ${ }^{90}$. A inauguração do cabo telegráfico transatlântico, ligando a Europa à América do Norte, significou uma grande conquista do homem sobre a natureza.

Num texto de 1866, Du Sentiment de la Nature dans les Société Modernes(Do sentimento da natureza nas sociedades modernas), Reclus descreve o amor a uma natureza, ou a uma geografia física, escarpada, acidentada e alta que transmite fascinação. As áreas planas seriam de extrema monotonia. Uma natureza alta, onde a montanha oferece mais obstáculos ao homem, sua "dominação" exige maiores esforços e levam a um prazer mais sofisticado e intenso. Neste momento, se desenvolvem na Europa os clubes expedicionários que visavam criar grupos para exploração de novos lugares e de lugares selvagens, tais como os clubes alpinos com o intuito de conquistar as montanhas européias; e os clubes de turismo, que passaram 
a publicar alguns relatos e viagens e instituir a ideia de viagens expedicionárias. Uma ideia muito interessante trabalhada por Reclus, neste texto, refere-se às glórias e triunfos que o homem alcançava cada vez que um novo pico de uma montanha era conquistado, e inserido nos mapeamentos, passando a ostentar uma bandeira, um símbolo do poder de dominação humana.

A produção de ideias de natureza será fortemente influenciada pelas obras de pintores e fotógrafos, criando um padrão estético de representação da natureza, a partir de algumas viagens ao redor do mundo, ou baseando-se em descrições e relatos de outros viajantes. De acordo com Reclus (2002), passa-se a "frequentar" mais e mais intimamente a natureza graças às obras de arte que reportavam as memoráveis viagens. Todos os homens cultos podem agora compreender a fisionomia de diversas regiões do globo. As imagens da natureza brasileira foram difundidas na Europa desta maneira.

Nos países mais industrializados, onde as indústrias têm sido as maiores forças para modificar tanto o conteúdo das ideias quanto a aparência da natureza, os desejos dos homens têm cada vez mais se imposto sobre as repetições cíclicas e sem intenção da natureza. Entretanto, para Reclus (1886), uma das maiores conquistas do homem sobre a natureza é a previsão do tempo. A meteorologia seria uma das mais importantes ferramentas para libertar o homem da natureza. Com a previsão do tempo, os furacões perdem seu poder sobre o homem. Mas há, entretanto, um triunfo ainda maior que aquele da previsão da sucessão dos fenômenos meteorológicos, que é a vitória obtida pela modificação do clima ${ }^{91}$. A modificação dos climas seria uma forma de melhorar a saúde pública nas cidades, bem como poderia representar um incremento às atividades agrícolas.

O ideal do homem é o ideal que irá prevalecer. Quando o ideal é nada mais que a mera reclamação de chão para cultivo, tudo será sacrificado para este fim, como a variedade e originalidade das espécies e toda a beleza da vegetação. Mas o desejo de obter culturas produtivas, a partir da terra, pode ser suplantada pelo desejo de adoração à terra, dando-lhe um grande esplendor através da adição de arte à natureza; [...] não resta dúvida que irá suceder-se uma mudança material do mundo vegetal de acordo com seus desejos, e em dando-se esta transformação, ao invés de sua primitiva originalidade, uma nova beleza irá se constituir para responder a um sentimento com sabor estético ${ }^{92}$.

A influência do homem sobre a natureza não é apenas associada a melhoria da sua produtividade, mas também é composta com uma forte componente estética, e isto vem caminhando com a história das ideias e conceitos de natureza desde o Período Clássico. Assim, para Reclus (1886), a ação do homem é tão poderosa no empreendimento da drenagem de pântanos e lagos, na derrubada dos obstáculos 
entre diferentes países e na modificação da primitiva distribuição dos animais e das espécies vegetais, que estes fatos adquiriram uma importância decisiva nas mudanças pelas quais a superfície externa do globo tem passado. Esta ação do homem pode embelezar a terra, mas ela também pode desfigurá-la, de acordo com os costumes e as condições sociais de qualquer nação, ela contribui tanto para a degradação ou para a glorificação da natureza. O homem molda dentro de sua própria imagem o país ao qual pertence ${ }^{93}$.

Adornar e melhorar a natureza é a função da civilização e da cultura que separaram os homens cultos e civilizados dos bárbaros, que apenas destróem a terra, que apenas desfiguram a face da natureza sem acrescentar beleza. Esta condição estética da natureza humanizada está muito relacionada aos grandes jardins que tomaram lugar na Europa desde o Renascimento, principalmente com os grandes jardins nos palácios franceses e italianos, bem como naqueles voltados a exibição de plantas exóticas, como o Jardin des Plantes em Paris. Mesmo nos jardins onde a natureza já se encontrava enclausurada por formas geométricas regulares, ainda era possível sua melhora, sua adequação ao gosto estético humano. Neste sentido, Reclus (1886), cita os jardins do Imperador Yang-Ty, onde se tem o hábito de repor no lugar das flores e folhas que caem das árvores, uma folhagem artificial e flores feitas de seda, posteriormente impregnadas com perfume, tornando a ilusão mais completa $^{94}$.

Mas esta necessidade estética na melhora da natureza se dá concomitantemente, não se pode esquecer, com o advento do capitalismo e da proliferação da propriedade privada como mercadoria, como desejo e como direito. Portanto, a natureza, imbuída e valorada pelo seu conteúdo estético irá ser altamente incorporada à vida econômica da sociedade e seguirá a mesma lógica empreendida hoje pelos agentes do mercado imobiliário.

A apropriação da natureza, uma apropriação da apreciação estética da natureza, consistindo numa salva guarda das suas belezas como forma de agregação de valor à uma propriedade privada, passa também pela privação de sua componente material, separando-a dos olhares e dos usos de todos os homens, através de cercas ou muros, instaurando definitivamente uma única forma de apreciação e de contato com a natureza através da compra de uma propriedade.

Élisée Reclus também coloca uma questão instigante, na qual o homem só processa a beleza da natureza quando a mesma encontra-se filtrada, civilizada, enquadrada. Segundo Reclus (1886), a natureza muito selvagem é incompreensível para o homem, ele preferiria trechos da natureza que já foram digeridos pela vida social, possibilitando assim que sua imaginação envolva todo este trecho humanizado mais facilmente. Símbolos da natureza, como uma charmosa avenida salpicada de árvores ou um lago rodeado por estátuas, como um santuário, são mais valorizados 
pelo homem do que a natureza mantida em seu estado bruto. Isto se dá porque o desejo universal do homem é adaptar a terra para seus requerimentos e para tornar completa sua possessão para derivar, a partir disto, seus imensos tesouros. Ele cobre a terra com uma rede de estradas, ferrovias e cabos telegráficos; ele fertiliza seus desertos e se faz o mestre de seus rios ${ }^{95}$.

As concepções de Élisée Reclus, como a do homem sendo a tomada de consciência da natureza remete a uma das primeiras condições no mundo das ideias para se compreender a transformação da ideia de natureza, vista como algo meramente "natural", primitivo, physis ou primeira natureza, em algo muito mais humanizado e dotado de uma racionalidade inerente à vida humana. Esta mudança vai desde o primeiro período quando era a natureza que se relacionava com o homem, definindo as "regras do jogo", até o momento atual onde a sociedade se relaciona com o território, incluindo aí uma segunda natureza. A sociedade passa a acomodar a natureza no meio da sua vida social. ${ }^{96}$

Este domínio de uma forma de pensamento, ou melhor, de uma forma de comando da vida social, que o capitalismo exerce sobre a humanidade implica na constituição de um novo sentimento pela natureza, baseada na sua exploração visando o conforto individual e não uma emancipação coletiva. Este processo representa também a vitória do individualismo e da propriedade privada. Para Reclus (1985, p. 75),

um fato capital domina toda a civilização moderna: o fato de que a propriedade de um único indivíduo pode aumentar indefinidamente, e até mesmo, em virtude do consentimento quase universal, abarcar o mundo inteiro. O poder dos reis e dos imperadores é limitado, o da riqueza não o é. O dólar é o senhor dos senhores [...] O modelo essencial do civilizado europeu, ou melhor, do americano do norte, é de se preparar para o lucro, tencionando comandar os outros homens através do dinheiro todo-poderoso. Seu poder aumenta na proporção exata do seu haver.

Apesar disto, não se tem receio em acreditar que o acúmulo de conhecimento do homem sobre a natureza e a sua consequente assimilação seja algo perverso. A perversidade é dada pela forma que o mundo caminhou com a hegemonia do modo de produção capitalista e pelas formas de uso do conhecimento inerentes ao sistema de apropriação individualista tanto da cidade quanto da natureza. Ainda é possível acreditar numa visão otimista e esperançosa das relações do homem com a natureza como propunha Elisée Reclus ou do homem com o território como será mostrado no próximo capítulo, a partir das obras de Milton Santos. 


\section{NOTAS}

32 Neste período também o homem, de acordo com Lenoble (1969, p. 260), "vai habituar-se aos sacrilégios de Prometeu e de Ícaro: já não teme ser fulminado pelos deuses. Descartes, Galileu, Gassendi, todos os seus discípulos menores, têm doravante por evidência que conhecer é fabricar e que a Natureza nada mais faz do que realizar em ponto grande o que nós podemos obter por pormenores e à nossa escala, graças ao nosso engenho de técnicos. [...] Não só deixam de temer a cólera divina por esta violação da Natureza como creem que Deus nos deu a missão de trabalhar à sua imagem, de construir o mundo no nosso pensamento como ele o criou no seu, fornecendo as suas leis."

33 À título apenas de menção, pois não serão aprofundadas estas questões neste trabalho, houve um destaque de muitas obras e de uma produção intelectual durante o Período dos Descobrimentos sobre a relação entre clima e sociedade, bem como uma busca por sistemas de classificação climática e a influência dos climas no destino dos homens.

${ }^{34}$ De acordo com Lenoble (1969, p. 279), "mecanizada, a Natureza torna-se uma simples possibilidade de exploração técnica, em breve levada ao máximo pela indústria nascente e logo invasora. O homem trocou o seu modelo, a sua senhora, por uma ferramenta. Essa ferramenta é-lhe entregue sem uma nota a explicar o seu modo de emprego. O homem, a principio divertido, não vai tardar a apavorar-se com o seu poder e com o vazio que criou desta forma ao redor dele".

35 FULTON, W. Nature and God. Edimburgo, 1927, p. 134, citado por GLACKEN, 1996.

36 Outra obra, que apesar de ter sido escrita num momento anterior foi mais difundida no Período dos Descobrimentos, também contribuiu para o entendimento do homem como um melhorador da natureza. On the art of building in ten books, de Leon Battista Alberti, o autor coloca, já no prefácio, como certas condições ambientais facilitam algumas formas de enfermidades, os homens devem modificar o meio. A sociedade, suas edificações e as invenções criadas estão todas inter-relacionadas com os contornos naturais. Além disto, os valores como utilidade, salubridade e comodidade não são suficientes para que uma cidade ou um edifício seja adequado aos homens, é preciso que se considere o homem como um ser sensível e, desta forma, cabe a suas construções instituir um valor estético e devem ser obras contidas também de beleza.

37 "La negación de un deterioro de la naturaleza era también una creencia afirmativa, lo mismo que lo era el abandono de la analogía biológica apliada a la naturaleza misma”. (GLACKEN, 1996, p. 376)

38 "Ray rechazó la creencia en el agotamiento y la disolución del mundo, sobre bases filosóficas, religiosas y científicas; sus objecciones descansaban también en observaciones del estado actual de la naturaleza, en líneas similares a las del uniformitarismo de la geología del siglo XIX. En la naturaleza, decía, no hay nada que manifieste o permita inferir una futura disolución, si bien algunos accidentes poco probables (diluvios, extinción del sol, erupción de un fuego central encerrado en la tierra, la sequedad y disposición inflamable de la tierra en la Zona Tórrida, que podría ser incendiada por volcanes, o una erupción simultánea de todos estos) podrían arruinar la tierra." (GLACKEN, 1996, p.38)

39 Autor do Ciclo Geográfico ou do Ciclo de Erosão

${ }^{40}$ citado por GLACKEN, 1996

${ }^{41}$ Para Marsílio Ficino (Théologie Plantonicenne de l'immortalité des ames, apud GLACKEN, 1996), o homem não se limita a inventar, mas também a melhorar suas invenções. Imita todas as obras da natureza divina, corrige ou melhora as obras da natureza inferior. Assim, pois, o poder do homem é quase similar ao da natureza divina. [...] O homem não só faz uso dos elementos, mas também os embeleza, coisa que nunca fez nenhum animal. De que maravilhoso modo cultiva o solo por toda a terra e constrói edifícios e cidades, com que destreza controla as vias navegáveis. 
42 "Después del año 1600, los molinos de viento se convirteron en activas bombas de agua en gran escala. [...] En la península al norte de Amsterdan había contrado hacia 1640 hasta veintesiete lagos desecados por el bombeo, y él mismo propuso drenar el Harlemmermeer con la ayuda de ciento sesenta molinos de viento." (GLACKEN, 1996, p.441)

43 Para Lineu (apud GLACKEN, 1996), o homem possui a capacidade de mudar e utilizar a natureza, sendo estas ações comprovações de sua criatividade como nos casos de domesticação de animais selvagens ou na escolha e disseminação de plantas que lhe são úteis. As ideias de Lineu inserem um sistema de ideias e conceitos utilitários e antropocêntricos de natureza. A Terra é possuidora de um sistema natural que se autorenova e se autopurifica, além disto, todas as suas transformações também se dão na forma de processos cíclicos onde não há perda mas sim mudança de matéria natural.

44 "Man has transported a plant from its native habitat to a new soil, he has introduced a new geographical force to act upon it, and this generally at the expense of some indigenous growth which the foreign vegetable has supplanted. The new and the old plants are rarely equivalents of each other, and the substitution of an exotic for a native tree, shrub or grass, increase or diminishes the relative importance of the vegetable element in the geography of the country to which it is removed". (MARSH,1965, p. 54).

45 Para Glacken (1996), Kant continua ainda sua interpretação da relação do homem com a natureza, sendo que para ele a liberdade da causalidade do homem lhe permite adaptar as coisas físicas aos fins que ele propõe.

46 "Como el hombre valora más, en sí mismo y en los otros, aquellos procesos que son intencionales y con propósito, quiere asignar tambiém intenciones y propósitos a la Naturaleza, porque su concepto de esta no puede ir más allá del concepto que él se ha formado de sí mesmo". (apud GLACKEN, 1996, p. 495)

${ }^{47}$ No naturalismo, de acordo com Lenoble (1969, p. 301), "a Natureza volta a ser, mais uma vez, a Mãe fecunda dos homens, que recomeçam a pedir-lhe uma regra dos costumes. Durante esse tempo, a ciência continua, por vias sempre mais seguras, a sua exploração metódica da Natureza. Mas torna-se bem claro agora que a Natureza do físico, cada vez mais matemático e que acaba de matematizar a química com Lavoisier e de mecanizar com Spallanzani os fenômenos até aí misteriosos da geração, já nada tem a ver com a natureza dos moralistas e dos 'filósofos' desse tempo."

${ }^{48}$ Reafirma-se aqui que o objetivo no estudo das ideias e conceitos de natureza na geografia tem como foco principal àquelas contribuições relacionadas ao que será denominado como Geografia Crítica. Neste momento, apenas se apresenta uma indicação de outra possibilidade de entendimento da natureza que fortemente encontra-se presente na história do pensamento geográfico.

49 Neste encontro entre o Velho e o Novo Mundo, considera-se aqui tanto as Américas quanto a Oceania. A forma de entendimento da natureza será usada para ratificar o processo de colonização e uso da terra. As teorias de classificação climática implicam em vantagens ou desvantagens culturais na mesma proporção. O clima cruel do Novo Mundo, tropical quente e úmido, havia impedido seus habitantes de alcançar a perfeição humana e eles se mantinham ao mesmo nível que os animais, possuindo atraso no desenvolvimento da mente e do corpo. E assim, as mesmas teorias que davam ênfase nas desvantagens naturais dos povos do Novo Mundo proclamavam a superioridade do clima temperado e a produção de uma raça humana mais desenvolvida, num mais puro direito natural. Isto sem mencionar as teorias de aumento e controle populacional de Robert Wallace e Malthus que começavam a tomar fôlego e insistiam num limite natural para a população terrestre.

${ }^{50}$ Para Lenoble (1969, p. 295), Buffon tinha um gênio "de sábio e a sua fé sincera mantêm bem ao abrigo das elucubrações dos 'filósofos', constrói também uma Natureza que Deus modelou inteiramente pelo desejo do homem." 
${ }^{51}$ Qu'elle est belle, cette Nature cultivée! Que par les soins de l'homme elle est brillante et pompeusement parée! (BUFFON, Histoire Naturelle, p. 59)

52 "Les fleurs, les fruits, les grains, perfectionnées, multipliés à l'infini; les espeses utiles d'animaux transportées, propagues, augmentées sans nombre; les espeses nuisibles réduites, confinées, réleguées; l'or et le fer plus nécessaire que l'or, tires des entrailles de la terre; les torrents contenus, les fleveus dirigée, resserrés; la mer, même soumise, reconnue, traversée d'un heminsphere à l'autre; la terre accessible partout, partout rendue aussi vivante que féconde; dans les vallées de riantes prairies, dans les plaines des riches pâturages, ou de moissons encore plus riches; les collines chargées de vignes et de fruits, leurs sommets couronées d'arbres utiles et de jeunes forêts; les deserts devenus des cites habitées par un people immense, qui circulant sans cesse, se répand de ces centers jusqu'aux extrémités; des routes ouvertes et fréquentées, des communications établies partout comme autant de témois de la force et de l'union de la société: mille autre monuments de puissance et de gloire, démontrent assez que l'homme maître du domaine de la Terre, en chargé, renouvelé la sufarce entière, et que tout temps il partage l'empire avec la Nature“. (BUFFON, Histoire Naturelle, p. 59-60)

53 "Enfin la face entière de la Terre porte aujourd'hui l'empreinte de la puissance de l'homme, laquelle, quoique subordinnée à celle de la Nature, souvent a fait plus qu'elle, ou du moins l'a si merveilleusement secondée, que c'est à l'aide de nos mains qu'elle s'est développée dans toute son étendue, e qu'elle est arrivée par degrés au point de perfection et magnificence où nous la voyons aujourd'hui“. (BUFFON, Les Époque... 7a. época, p. 92)

${ }^{54}$ Spinosa não atribui à natureza nem beleza nem feiúra, nem ordem nem confusão. Estes são produtos da imaginação. Também condena as concepções teleológicas de natureza, com a intenção de mostrar que a natureza não faz nada e bem como não concorda com as concepções que colocam a natureza como algo vantajoso ao homem. Todas estas formas de julgamento moral e utilitário da natureza parecem "acabar mostrando que a natureza, deuses e homens estão igualmente loucos". (SPINOSA, Ética, Parte I, Apêndice que segue a proposição XXXVI apud GLACKEN 1996, p. 351-352).

55 Segundo Luginbuhl (1992), em 1909, ocorre em Paris o I Colóquio de Proteção de Paisagens, tendo como filosofia central a beleza natural como sinônimo de moral. Deste colóquio publica-se uma carta pregando que o progresso é quem destrói a Natureza e, portanto, deve ser limitado. Os signatários eram contra a criação de estradas de ferro e vias de circulação, de extração de minérios e exploração da madeira e agricultura. É claro que o acesso ao progresso era condenado nas colônias e nos países mais pobres. Assim, produz-se um sistema de ideias que ratifica conceitos afinados ao discurso político, econômico, social e cultural dominantes, que assumem um tom protecionista, não da Natureza, mas do estilo de vida da elite européia, mantido graças a uma forma de produção excludente e beneficiando com o monopólio o acesso dos produtos europeus nos territórios condenados a serem grandes reservas de gentes, animais e plantas.

56 "Si bien Marx define la naturaleza - el material de la actividad humana - como aquello que no es subjetivo, que no se disuelve en los modos de apropiación humana, lo que es directamente no idéntico al hombre en el sentido ontológico". (SCHMIDT, 1976, p. 23)

57 "La naturaleza se mantiene en un plano abstracto. La naturaleza en su conjunto es para él un sustrato ajeno a la historia, homógeneo, cuya resolución en una dialética de sujeto y objeto constituye el meollo de la crítica marxista. La naturaleza es para Marx un momento de la praxis humana y al mismo tiempo la totalidad de lo que existe." (SCHMIDT, 1976, p. 23)

${ }^{58}$ Além disto, "o trabalhador nada pode criar sem a natureza, sem o mundo externo sensível. Este é o material onde se realiza o trabalho, onde ele é activo, a partir do qual e por meio do qual produz coisas. Mas assim como a natureza fornece os meios de existência do trabalho, no sentido de que o trabalho não pode viver sem objectos, nos quais se exercita, de igual modo ela proporciona os meios de existência em sentido mais restrito, a saber, os meios de existência física do próprio trabalhador." (MARX, 1975, p.160) 
59 "la naturaleza, tomada en forma abstracta, por sí, fijada en la separación del hombre, no es nada para el hombre”. (MARX, Manuscritos parisienses apud SCHIMDT, 1976, p. 26)

${ }^{60}$ Segundo Marx (1980, p. 79), "é evidente que o ser humano, por sua atividade, modifica do modo que lhe é útil à forma dos elementos naturais. Modifica, por exemplo, a forma da madeira, quando dela faz uma mesa. Não obstante a mesa ainda é madeira, coisa prosaica, material. Mas, logo que se revela mercadoria, transforma-se em algo ao mesmo tempo perceptível e impalpável.”

61 "Uma máquina que não serve no processo de trabalho é inútil. Além disto, deteriora-se sob a poderosa ação destruidora da natureza. O ferro enferruja, a madeira apodrece. Fio que não se emprega na produção de tecido ou malha, é algodão que se perde. O trabalho vivo tem que se apoderar dessas coisas, de arrancá-la de sua inércia, de transformá-las de valores de uso possíveis em valores de uso reais e efetivos". (MARX, 1980, p. 207)

${ }^{62}$ Como diz Marx (1980, p. 203), "a terra (que do ponto de vista econômico, compreende a água) que, ao surgir o homem, o provê com meios de subsistência prontos para utilização imediata, existe independentemente da ação dele, sendo o objeto universal do trabalho humano. Todas as coisas que o trabalho apenas separa de sua conexão imediata com seu meio natural constituem objetos de trabalho, fornecidos pela natureza. Assim, os peixes que se pesca, que são tirados do seu elemento, a água, a madeira derrubada na floresta virgem, o minério arrancado dos filões. Se o objeto de trabalho é, por assim dizer, filtrado através do trabalho anterior, chamamo-lo de matéria-prima”.

63 "Só conhecemos uma única ciência, a ciência da história. A história só pode ser considerada a partir de dois aspectos, dividindo-a em história da natureza e história da humanidade. Apesar de não termos que dividir estes dois aspectos; entretanto, existem os homens, a história da natureza e a história dos homens que se condicionam reciprocamente" (A ideologia alemã, p. 31).

${ }^{64}$ Nesta diferenciação entre animais e homem, Marx (1975, p. 165), escreve ainda que "o animal apenas produz a si, ao passo que o homem reproduz toda a natureza [...] o animal constrói apenas segundo o padrão e a necessidade da espécie a que pertence, ao passo que o homem sabe como aplicar o padrão apropriado ao objecto; deste modo, o homem constrói também em conformidade com as leis da beleza”.

${ }^{65}$ ferramentas - técnicas $=$ porções da natureza corporificadas (as primeiras ferramentas reproduziam em proximidade algumas formas encontradas na natureza) através da astúcia do raciocínio humano e que serão formas de mediação do homem. Pela visão marxiana da mediação pelas ferramentas, o objeto fruto de sua utilização pode absorver, tornar-se idêntico, incorporar-se materialmente ao produto do trabalho ou pode consumir-se sem resíduos.

${ }^{66}$ Entende-se por um projeto de emancipação coletiva da natureza, de maneira similar ao que Marx faz da liberação do homem do julgo da religião. A emancipação coletiva visa constituir nas atividades cotidianas do homem um sistema de "relações racionais claras entre os homens e entre estes e a natureza. A estrutura do processo vital da sociedade, isto é, do processo da produção material, só pode desprender-se do seu véu nebuloso e místico, no dia em que for obra de homens livremente associados, submetida a seu controle consciente e planejado. Para isso, precisa a sociedade de uma base material ou de uma série de condições materiais de existência, que, por sua vez, só podem ser o resultado natural de um longo e penoso processo de desenvolvimento". (MARX, 1980, p. 88/89)

${ }^{67}$ As ciências e as técnicas têm um papel fundamental no projeto de emancipação da sociedade. De acordo com Marx (1975, p. 201), "a ciência natural penetrou tanto mais practicamente na vida humana através da indústria, transformou-a e preparou a emancipação da humanidade, muito embora o seu efeito imediato tenha consistido em acentua a desumanização do homem. A indústria é a relação histórica real da natureza [...]“. (p. 201) 
${ }^{68}$ Marx também escreveu sobre a crescente deterioração da natureza. "Com a preponderância cada vez maior da população urbana que se amontoa nos grandes centros, a produção capitalista, de um lado, concentra a força motriz histórica da sociedade, e, de outro, perturba o intercâmbio material entre o homem e a terra, isto é, a volta à terra dos elementos do solo consumidos pelo ser humano sob e forma de alimentos e de vestuário, violando assim a eterna condição natural da fertilidade permanente do solo. Com isto, destrói a saúde física do trabalhador urbano e a vida mental do trabalhador do campo. Mas, ao destruir as condições naturais que mantêm aquele intercâmbio, cria a necessidade de restaurálo sistematicamente, como lei reguladora da produção e em forma adequada ao desenvolvimento integral do homem. [...] A produção capitalista, portanto, só desenvolve a técnica e a combinação do processo social de produção, exaurindo as fontes originais de toda riqueza: a terra e o trabalhador". (MARX, 1980, p. 578 e 579)

69 Somente depois de lutas milenares, quando "se fixou finalmente a diferenciação da mão e do pé, donde resultou o caminhar erecto, o homem se tornou diferente do mono; constituiu-se o fundamento do desenvolvimento da linguagem articulada e da formidável expansão do cérebro que, desde então, tornou intransponível o abismo que separa o homem do macaco". (ENGELS, 1991, p. 25)

${ }^{70}$ Este objetivo coletivo na ação sobre a natureza, esta aproximação entre os homens é aquilo que se tem referido como um projeto de emancipação coletiva, que também será abordado por Engels. Assim, segundo ele (1990, p. 96) "a liberdade, pois, é o domínio de nós próprios e da natureza exterior, baseado na consciência das necessidades naturais; como tal é, forçosamente, um produto da evolução histórica. Os primeiros homens que se levantaram do reino animal eram, em todos os pontos essenciais de suas vidas, tão pouco livres quanto os próprios animais; cada passo dado no caminho da cultura é um passo no caminho da liberdade. Nos primórdios da história da humanidade, realizou-se a descoberta que permitiu converter o movimento mecânico em calor: a produção do fogo pela fricção; o progresso tem, atualmente, como sua etapa terminal, a descoberta que transforma, inversamente, o calor em movimento mecânico: a máquina a vapor. [...] O fogo, obtido dessa forma, foi que permitiu ao homem o domínio sobre uma força da natureza, emancipando-o definitivamente das limitações do mundo animal".

71 "O animal apenas utiliza a Natureza, nela produzindo modificações somente por sua presença; o homem a submete, pondo-a a serviço de seus fins determinados, imprimindo-lhe as modificações que julga necessárias, isto é, domina a Natureza. E esta é a diferença essencial e decisiva entre o homem e os demais animais; e, por outro lado, é o trabalho que determina essa diferença”. (ENGELS, 1991, p. 223)

72 Neste trabalho utilizou-se a versão original de 1874 e uma versão de 1965 da obra de Marsh, e por esta razão que aqui há menção as duas datas, mas que se referem a mesma obra.

73 "Indicate the character and, approximately the extent of the changes produced by human action in the physical conditions of the globe we inhabit and incidentally, to illustrate the doctrine that man is, in both kind and degree, a power of a higher order than any of other forms of animated life, which, like him, are nourished at the table of bounteous nature”. (MARSH, 1874, prefácio)

74 "These changes for evil and for good have not been caused by great natural revolutions of the globe, nor are they by any means attributable wholly to the moral and physical action or inaction of the peoples, or in all cases, even of the races that now inhabit these respective regions. They are products of a complication of conflicting or coincident forces, acting through a long series of generations. [...] So far they are purely the calculated and desired results of those simple and familiar operations of agriculture and of the social life" (MARSH, 1965, p. 19)

75 "The earth was not, in its natural condition, completely adapted to the use of man, but only to the sustenance of wild animals and wild vegetation. Hence, a certain measure of transformation of terrestrial 
surface, of suppression of natural, and stimulation of artificiality modified productively becomes necessary. This measure man has unfortunately exceed" (MARSH,1965, p. 38)

76 "In recent times operation for this purpose have assumed a magnitude, and been attended with economical as well sanitary and geographical effects, which entitle them to a high place in the efforts of man to ameliorate the natural condition of the soil he occupies." (MARSH, 1874, p. 435)

77 "Fields where nature is brought in conflict with man, she first resists his attempts at interference with her operations, then, finding him the stronger, quietly submits to his rule, and ends by contributing her aid to strengthen the walls and shackles by which he essays to confine her." (MARSH, 1874, p. 503)

78 "the creation of man was the introduction of a new element into nature, of a force wholly unknown to earlier periods. It is a new telluric force which is power and universality may be compared to the greater forces of the earth". (STOPANINI, apud MARSH, 1874, p. 605)

79 "L'homme est l'âme de la terre."

80 "L'homme digne de sa mission assume par cela même une part de resposabilité dans l'harmonie et la beauté de la nature environnante". (RECLUS, 2002, p. 35)

81 "L'étude de la surface du globe accompagne donc de la façon la plus intime l'étude de l'humanité". (RECLUS, 2002 , p. 81)

82 "Avec ces changements de milieu, qu'a pu se procurer l'homme deans ses révoltes contre la dure nécessité, commence la géographie proprement dite.” (RECLUS, 2002, p. 82)

83 "la terre fait l'homme e que l'homme refait la terre incessamment" (RECLUS, 2002, p. 104)

84 "Man is incessantly engaged in a conflict with the globe on which he dwells; having submitted a child of nature during the ages of primitive barbarism, he has gradually emancipated himself, and which endeavoring to adapt to his uses the forces of the earth, he has, so to speak, made them his own. (...) For a long time we were nothing more than its unconscious products, we have become increasingly active agents in its history." (RECLUS, 1886, p. 408)

85 "Man had made the soil of the earth his own by science he had commenced to adapt it to his use by cultivation." (RECLUS, 1886, p. 446)

86 "L'histoire agricole des Pays-Bas est le récit d'un combat sans trêve entre l'homme et l'ocean, et dans ce combt c'est l'homme qui a reporté la victoire." (RECLUS, 2002, p. 43)

87 "The astonishing regularity of the landscape is undisturbed, save by the masses of buildings in the large towns, the parks which surround them, and the roads and railways crossing the canals in an oblique direction as they emerge from the cities." (RECLUS, 1886, p. 457)

88 "The knowledge of the evil has led to the discovery of the remedy." (RECLUS, 1886, p. 460)

89 "Ideas become a patrimony common to all, and the creative intelligence of workers has been enabled to develop and increase." (RECLUS, 1886, p. 468)

90 "His liberty is set free from the obstacles imposed by time and space, and he becomes, as it were, personally present at all the points of space which the conducting wire brings into relation with his thoughts." (RECLUS, 1886, p. 476)

91 "There is, however, a triumph still greater than that of foreseeing the succession of meteorological phenomena, and that is the victory obtained by the modifications of climates." (RECLUS, 1886, p. 483)

92 "The ideal of man is the ideal which will always prevail. As long as the ideal is nothing else but the mere reclamation of ground for cultivation, everything will be sacrificed to this point, the variety and 
originality of species, and all beauty of vegetation. But when the desire of obtaining productive crops from the earth is supplemented by that of adoring it and of giving to it all the splendor which art adds to nature; [...] no doubt it will succeed in materially modifying the vegetable world according to its desire, and in giving it, instead of its primitive originality, a new beauty which will respond to a sentiment of aesthetic taste." (RECLUS, 1886, p. 487)

93 "The action of man is so powerful an agency in draining marshes and lakes, in smoothing down the obstacles between different countries, and modifying the primitive distribution of animal and vegetable species, that these very facts become of decisive importance in the changes which the outward surface of the globe is undergoing. This action of man may embellish the earth, but it may also disfigure it; according to the customs and social condition of any nation, it contributes either to the degradation or glorification of nature. Man moulds into his own image the country which he inhabits..." (RECLUS, 1886, p. 490)

94 "The gardens of the Emperor Yang-Ty were in the habit of replacing the flowers and leaves which fell from the trees by artificial foliage and flowers mad of silk, the latter being impregnated with perfume so as to render the illusion more complete.” (RECLUS, 1886, p. 492)

95 "The universal wish of man is to adapt the earth to his requirements, and to take complete possession of it in order to derive from it its immense treasure. He covers it with a network of roads, railways, and telegraphic wires; he fertilizes its deserts and makes himself master of its rivers." (RECLUS, 1886, p. 494)

${ }^{96}$ Retomando as ideias de Reclus, sobre o grau de modificação que o homem tinha impresso à natureza até o momento de sua análise (século XIX), o homem ainda não tinha visto suas obras superarem em tamanho e complexidade as ilhas constituídas pelos corais. Mas isto se refere a um estágio ainda inicial da dominação da natureza, pois no momento atual assiste-se a uma infinidade de grandes obras que representam vastas extensões territoriais, como os aterros marinhos. Os homens até estão produzindo ilhas, como exemplo pode-se citar a ilha onde fica o aeroporto de Kansai, no Japão, ou as famosas ilhas-condomínios em Dubai. Aqui cabe um comentário, enquanto a natureza sempre foi marcada pela busca de repetições de padrões, o homem imprime a sua variedade cultural sobre a mesma, mas com o advento do modo de produção capitalista e a globalização, observa-se uma retomada a uma repetição "quase natural ou automática" de padrões e símbolos de construções humanas, um retorno à natureza? 


\title{
V - O HOMEM E O TERRITÓRIO
}

\author{
Os conteúdos e limites da natureza no período atual \\ O homem e a natureza a mediação pelo território \\ A natureza como valor
}

Os séculos XIX e XX marcam definitivamente, através da produção, das técnicas, das indústrias e mesmo da cultura, a incorporação da natureza à vida social. Os objetos, as ações, as crenças e os desejos dos homens passam a incluir a natureza ou as representações da natureza. Insere-se também a realidade esmagadora da vida humana e das perspectivas da sociedade, como escreve Santos (1994). O homem torna-se agente criador de ciclos e processos que só eram observados na natureza. Continuando com Santos (1994, p. 6), "o natural cede lugar ao artefato e a racionalidade triunfante se revela através da natureza instrumentalizada, esta, portanto, domesticada nos é apresentada como sobrenatural". Uma natureza sempre redesenhada a cada momento da História, mas de maneira contundente, depois de sua inserção no âmbito da História Social e com o desencantamento do mundo.

A transformação da natureza, de uma primeira natureza para uma segunda natureza, se dá pelo uso das técnicas e ferramentas, empregadas como prolongamento do corpo humano, que assim coloca sua marca sobre a natureza. A partir desta transformação, o homem passa não só a modificar a natureza, como também produzir espaço. Na sua ação, relacionada à produção, não é possível distinguir esta ação em si e o ato de produzir o espaço ${ }^{97}$.

A proximidade da natureza instiga a se pensar cada vez mais seus conteúdos e limites, através de uma análise histórica dos conceitos e dos significados da natureza, no período atual, realçados com as novas descobertas e redescobertas. Define-se um período marcado pelas relações do homem não mais com uma natureza pura, mas sim como uma natureza socializada e inserida no território. 
Neste diálogo entre a sociedade e o território usado, estão inseridos os objetos naturais e artificiais, as cristalizações presentes no espaço e suas rugosidades. Tudo sendo movimentado pela própria sociedade que é quem dá vida e anima as formas $^{98}$. A partir desta constatação, para Santos (1988, p. 88)

o homem necessita aprender a natureza a fim de poder apreendê-la. A riqueza do ensinamento da natureza é proporcional à ação do homem sobre ela; quanto maior a troca com a natureza, tanto maior o processo de intercâmbio entre os homens. A relação entre o homem e seu entorno é um processo sempre renovado que tanto modifica o homem quanto à natureza.

Nota-se, claramente, nesta citação as ideias de Marx, que o homem modifica a natureza ao mesmo tempo em que modifica a si mesmo. Para Harvey (2000) foi a relação que o homem desenvolveu com a natureza que permitiu que se pudesse pensar e melhorar o futuro. Como ser sensitivo, o homem, em relação metabólica com o mundo, o modifica e, fazendo isso, muda a si mesmo através de seu trabalho.

De acordo com Soper (2000), deve-se, primeiramente, compreender como "esta palavrinha complexa" que é a "natureza" é falada e entendida. Na atualidade, duas grandes possibilidades, segundo a autora (op.cit.), baseadas em posições teóricas e políticas, se colocariam. A primeira refere-se a uma visão afirmativa da natureza (nature - endorsing), relacionada, principalmente, ao movimento ecológico/ ambientalista, como o Greenpeace, que no Reino Unido tem mais filiados do que qualquer partido político. A segunda forma de entendimento é a dos sépticos da natureza (nature - sceptical), que seriam representados pelos movimentos posmodernistas, socialistas e marxistas.

Continuando suas considerações, Soper (2000) escreve que os ecologistas tendem a invocar a natureza como um domínio de valor intrínseco [a questão dos desígnios da natureza], verdade ou autenticidade e têm posição relativamente indefinida quanto às questões epistemológicas e de representação. Sobre a posição "ecologista", Mendes (1993, p. 20), coloca que

certas linhas do pensamento ecológico propugnam por uma solução 'edênica' - à volta a natureza, a reinserção do homem no meio natural como um ser meramente natural. [...] e desprezo pelas conquistas do desenvolvimento científico, tecnológico e cultural. 
Buarque (1993) fala mesmo de um biocentrismo que nega o homem em sua totalidade e prega uma inconsequente centralidade natural.

As concepções mostram que a natureza carrega consigo um peso simbólico e ao mesmo tempo contraditório e complexo, sendo entendida diferentemente por diversas formas de pensamentos e ideologias. Sua representação também adquire, no período atual, uma gama variada de possibilidades. Reafirma-se neste trabalho que o objetivo não é o confronto entre estas várias possibilidades, mas sim apresentar o desenvolvimento da visão otimista da ação do homem sobre a natureza, de como esta ação foi ao longo da história aproximando, transformando e incorporando a natureza à vida cotidiana, próxima da ideia de Buarque (1993), de um neo'antropocentrismo'. Para o autor (op.cit., p. 67), "a descoberta da natureza já ocorre, antecedendo a formulação de uma nova visão onde o homem seja o centro e a razão de um projeto viável fisicamente, decente eticamente e cujo valor dependa da natureza, que é parte do próprio valor e base da criação de novos valores".

A variedade de ideias e conceitos de natureza ${ }^{99}$ está associada a um caráter intrínseco da natureza, que é ser algo dentro do tempo. Na concepção de Ortega y Gasset (1973), isto significa que seu meio de existir é no agora, no presente, mas o agora e o presente são instantâneos; não se termina de nomeá-lo e então ele escoa, cessa de ser o agora e o presente e converte-se num passado, em algo que não mais é e sim era. De acordo com Whitehead (1955), a natureza é um processo, que física e simbolicamente, tem suas formas de compreensão e representação muito diferentes desde a pré-história até os dias atuais. Como foi demonstrada nos capítulos anteriores, esta mudança ocorreu devido ao entendimento técnico e científico dos processos naturais e das formas de atuação destes processos. No período pré-científico, o maior medo do homem era a natureza e atualmente as causas dominantes nos medos dos homens são causadas pelo próprio homem. "É do homem de hoje que o homem pode receber seus maiores sofrimentos. Os fenômenos naturais são desarmados porque são explicados".

De acordo com Santos (1999, p.117)

no início, as ações se instalavam nos interstícios das forças naturais, enquanto hoje é o natural que ocupa tais interstícios. Antes, a sociedade se instalava sobre lugares naturais, pouco modificados pelo homem, hoje, os eventos naturais se dão em lugares cada vez mais artificiais, que alteram o valor, a significação dos acontecimentos naturais.

O desenvolvimento da técnica e sua interação com a ciência e a indústria aceleram este processo. Amplia-se a esfera da diversificação da natureza (de que 
fala WHITEHEAD, 1955), agora não mais operada pelos ciclos naturais, mas sim pelas forças sociais. Entretanto, se a artificialidade dos objetos sociais e sua eficácia acabam por distanciá-los das incertezas das coisas da natureza, a técnica propicia a estandardização dos objetos e também das ações, ou seja, do próprio território.

De acordo com Santos (1994, p.19),

sem o homem, isto é, antes da história, a natureza era uma. Continua a sê-lo, em si mesma, apesar das partições que o uso do planeta pelos homens lhe infligiu. Agora, porém, há uma enorme mudança. Una, mas socialmente fragmentada [pelos usos que os diferentes grupos sociais fazem dela a partir de suas disponibilidades técnicas], durante tantos séculos, a natureza é agora unificada [mundializada, torna-se um padrão universal e mesmo um problema global com as mudanças climáticas e a inserção do debate político] pela História, em benefício de firmas, Estados e classes hegemônicas. Mas não é mais a Natureza Amiga, e o Homem também não é mais seu amigo.

A relação que a sociedade possui hoje com a natureza, ou com o território onde se insere a natureza, se dá num "mundo que a técnica construiu para nós, somos hipnotizados pela lei do número" 100 , um mundo geométrico das quantidades e valores econômicos e não das qualidades e valores fraternais. Assim, a natureza hoje se constitui, de acordo com uma proposta de Lenoble (1969), numa "coisaimagem", muito mais imagem do que coisa. Nesta relação, os homens não enxergam os fenômenos sociais, políticos ou econômicos que penetram na ideia de natureza, eles continuam a ver apenas uma imagem romântica da natureza, que é captada e apropriada, como por exemplo, pelos empreendimentos imobiliários nas grandes cidades.

Segundo Soper (2000), não se pode fazer distinção entre a realidade da natureza e sua representação cultural, o que não é por si mesma conceitual. Isto não justifica a conclusão de que não há distinção ontológica entre as ideias que se tem de natureza e aquelas sobre as quais as ideias são. Esta constatação ocorre porque a natureza é apenas significativa no discurso humano.

Apesar disto, ainda é difícil distinguir o que é, em realidade, natural, principalmente quando se depara somente com as formas. A representação da natureza é ligada às experiências culturais e ideológicas de cada sociedade ou grupo, relacionando-se também com as variantes estéticas que, a cada momento, são predominantes. Mitos, poesias épicas, dogmas religiosos, obras de arte são forças culturais inegáveis no modelamento das representações da natureza. 
O homem, sua inteligência, suas técnicas e seu conhecimento analítico passam a abranger toda a natureza e, desta forma, atinge-se, de acordo com Santos (1988), a possibilidade concreta de utilização de todas as coisas que se colocam na superfície do planeta. Torna-se imperioso que as disciplinas se renovem neste processo de instauração de uma nova fase das relações do homem com o espaço, no qual se insere a natureza socializada. Cria-se, de fato, uma universalidade com a presença humana em todas as partes do planeta, que efetivamente se mundializa. Além disto, segundo Santos (1999, p. 128), "o homem se torna capaz de gerar eventos naturais e de produzir fatos físicos ou então de mudar, por sua ação, a significação, o alcance, as consequências dos fenômenos naturais, incluindo-os na corrente de uma história humana universalizada".

Toda esta transformação instiga Milton Santos (2000a․, p. 18) a pensar que

de certo modo, acabou a natureza. Bem, dizer que a natureza acabou é uma forma de provocar uma discussão mais acesa. Na realidade, a natureza hoje é um valor, ela não é natural no processo histórico. Ela pode ser natural na sua existência isolada, mas no processo histórico, ela é social. Quer dizer, eu valorizo em função de sua história. Isso já ocorria antes, mas hoje é muito mais evidente. O valor da natureza está relacionado com a escala de valores estabelecida pela sociedade para aqueles bens que antes eram chamados de naturais. ${ }^{101}$

\section{UMA NATUREZA TECNIFICADA}

A ação humana sobre a natureza é uma necessidade. É um engano acreditar que o homem primitivo dispunha do que necessitava livremente na natureza. Este homem primitivo sofria perante as condições colocadas pela natureza o que dificultava sua existência e resultava em uma luta constante contra a natureza. ${ }^{102}$ Uma variedade de formas de relações do homem com natureza se estabelecem, se aperfeiçoam ou se aceleram:

- pela adaptação da natureza à necessidade de comida;

- pela "civilização" através do controle dos ciclos naturais, irrigação, da implosão de morros e montanhas, abrindo canais e túneis, construindo lagos, drenando pântanos; 
- pelo batismo ou pela definição dos nomes aos lugares. Para Santos (1999, p. 53), "o fato simples de reconhecer e nomear um objeto supõe um aprendizado, explícito ou implícito";

- pelo mascaramento da natureza para torná-la mais facilmente digerida ou consumida.

A modificação do mundo natural em território humano é legitimada pelas necessidades, requerimentos, desejos e esperanças que a vida coloca e podem ser vistas tanto como um projeto de emancipação coletiva ou pelo conforto produzido em nossa vida individual, de acordo com Habermas (1997). Segundo o geógrafo Elisée Reclus (1985, p. 42), "a primeira das condições para que o homem chegue um dia a transformar completamente a superfície do globo é a inserção da natureza à vida social, ao território". Para Soper (2000), a humanização da natureza, permite uma medida de alívio ao ser humano. Ela dá uma certa suspensão da moral universal que governa as relações entre as pessoas, e das lutas por autonomia que são ligadas a isto. Permite uma fuga da racionalidade que ao longo dos séculos o próprio homem construiu ${ }^{103}$.

A trajetória das ideias, bem como a materialidade das grandes cidades, que é apresentada nos dias atuais, acentua o papel da ação humana na definição dos conteúdos e limites da natureza, sua valoração, valorização, conservação e grau de dependência. O período atual também mostra claramente a construção cultural da natureza e como as concepções e representações sobre ela estão intimamente ligadas aos territórios construídos pelo homem e à vida cotidiana urbana.

O espaço, como um sistema de objetos e ações, apresenta-se mais e mais carregado de artificialidade, as quais, muitas vezes, não apresentam nenhuma relação horizontal com o grupo social que habita este espaço. Produz-se, desta maneira, uma configuração espacial ou territorial que nega com mais força a natureza primitiva dos meios naturais e torna-se claramente fruto de uma ação histórica e intencional dos homens. Nesta natureza inteiramente humanizada, nem as "plantas e animais são herdados das gerações anteriores, mas são criaturas da biotecnologia" (SANTOS, 1999, p. 242). Mas deve-se ter certa cautela neste processo, pois a força que o impulsiona é o comércio, o mercado, o consumo e a produção, associados à busca, apenas da satisfação individual.

Além disto, tem-se a "detecção do mundo a partir de satélites. É a primeira vez, na história do homem, que o mundo se torna realmente conhecido, o mundo no seu conjunto e no seu detalhe, em função de seu formidável progresso técnico" (SANTOS, $2000^{a}$, p. 28). A natureza passa a ser caracterizada como uma força produtiva. Todos os lugares do mundo foram atingidos por este fato direta ou indiretamente, em variadas velocidades e intensidades. Segundo Serres (1991, p. 138), 
aparelhados suficientemente longe de nossa Terra, podemos finalmente considerá-la inteira. O camponês, costas encurvadas, vivia dos sulcos e só a eles via; o selvagem só a sua clareira ou os atalhos pelo maciço florestal; o montanhês, seu vale, descoberto por pastagens; o burguês, a praça pública, vista do seu andar; o piloto de avião, uma porção do Atlântico [...] Eis uma bola sem muita nitidez, rodeada de turbulências: o planeta Terra tal qual o fotografaram pelos satélites. Todo.

De acordo com Harvey (2000), a imagem de satélite da NASA, que mostra toda a Terra como um globo, flutuando pelo espaço, foi rapidamente assumida como um ícone de uma consciência. Entretanto, esta nova consciência insere um elemento de super-acumulação do capital no período, com a conquista de novos mercados, maior exploração dos já conhecidos e uma característica cosmopolita da produção e do consumo. O próprio homem destrói, para Harvey (2000), as fundações geográficas - ecológicas, espaciais e culturais - de suas próprias atividades, construindo um mundo a sua própria imagem.

O avanço técnico transforma a natureza em algo cada vez mais social do que natural ${ }^{104}$. A natureza insere-se na possibilidade do homem produzir sua história. O processo histórico - social e não natural - controla, incorpora e produz naturezas, enquadrando-a nas qualidades humanas. Neste sentido, a sociedade toma posse do que era visto como um presente divino (MARX \& ENGELS, 1980). ${ }^{105}$

De acordo com Bachelard (1983, p. 146), a técnica se tornou muito mais poderosa que a natureza, pois

é impossível levar o som de um continente a outro por meios
naturais, por mais que possante que se imagine o porta-voz. O
intermediário eletrônico é humano, é social. Acima da biosfera
e abaixo da ionosfera, o homem determinou uma radiosfera
sujeita a uma causalidade eminentemente técnica. Essa técnica
pode, sem dúvida, ser danificada por parasitas, por perturba-
ções magnéticas. Mas esses parasitas, essas desordens naturais,
essas desordens causadas pela natureza só fazem compreen-
der melhor a força da organização racional e técnica que a
limita e que as anula.

Entretanto, cabe ressaltar, segundo Habermas (1997), que a técnica, como projeto histórico-social, é repleta da intencionalidade dos sujeitos dominantes que usam este aparato no controle ${ }^{106}$, tanto da natureza quanto da sociedade. 
Transmutar e transformar a natureza em sociedade é uma mudança na qualidade daquilo que é natural para aquilo que é humano. Primeiramente, esta transmutação se deu na superfície da natureza, na sua aparência, acreditando que mudando a aparência, mudar-se-ia a qualidade. Hoje, as possibilidades técnicas aperfeiçoam cada vez mais esta metáfora alquimista. O homem chega mais perto de mudanças nas qualidades essenciais da natureza, através da genética. Uma materialidade racionalista preenche a natureza em profundidade. Cada vez mais esta substituição do natural pelo social acontece, aliada à ampliação das esferas do conhecimento humano e mais distante a natureza primitiva se encontra. ${ }^{107}$

Se as técnicas inserem uma constante dissociação entre o homem e a natureza, cabe a cultura propiciar algumas aproximações, mesmo que metaforicamente. Há sempre uma observação sobre a necessidade que os homens têm de se aproximar da natureza e isto pode ser dado tanto pela sua contemplação, controle ou transformação. O homem imita a natureza e ao mesmo tempo a desnaturaliza. Podese exemplificar esta relação dialética com um jardim onde há algo natural - plantas e flores - mas ao mesmo tempo social, cultural e técnico. A paixão pela geometria regular é a necessidade de enquadrar a natureza num padrão uniformizado e compreensível pela mente humana. A natureza apreendida é aprisionada em objetos e ações, com finalidades bem definidas. A relação do homem com a natureza passa a ser mediada por técnicas e objetos, como jardins, parques e bosques reflorestados.

A inserção da natureza na produção social do mundo é de acordo com Casini (1975), um fato presente na vida do homem desde as mais remotas culturas até a mais racionalista ${ }^{108}$. E para Merleau-Ponty (Marxisme et Philosophie, apud SCHMIDT, 1976), a transformação da natureza pela sociedade cria formas transnaturais, mas nada sobrenatural.

Preservam-se, conservam-se e valorizam-se aqueles elementos que moral, estética ou monetariamente são relevantes. Se em algum momento da história estes julgamentos foram feitos com um caráter subjetivo, nos dias atuais a definição de valores estéticos e monetários da natureza se dá num projeto extremamente objetivo e intencional, como no caso das incorporadoras e construtoras de condomínios de alto padrão, ou na escolha das embalagens de produtos industrializados com apelos à natureza.

Além disto, no período atual, os julgamentos estéticos e morais podem ser definidos pelos enquadramentos das janelas dos carros, trens ou aviões. Aliás, SOPER (2000) escreve que o enquadramento da visão da natureza, se insere num momento de supervalorização do gosto estético do motorista, onde a natureza é produzida, ou suas representações, tendo como design, uma rodovia. Uma natureza adaptada para as necessidades modernas. A concepção do homem sobre estas atrações da 
natureza é moldada de acordo com esta visão. Num mesmo espaço, diferentes objetos, sob sua aparência, instigam a desvelar as formas que se materializam na paisagem, em muitos casos, criando uma caricatura da natureza.

Em lugares de grande beleza cênica natural, uma praia, uma cachoeira, um parque, apesar deste apelo estético vinculado a uma natureza primeira, o que atrai as visitas são muito mais as facilidades de acesso do que as próprias belezas naturais, bem como as infra-estruturas: sanitários, lanchonetes e até lojinhas de souvenires. ${ }^{109}$ Será que Elisée Reclus estava certo, a natureza primitiva é monótona aos olhos dos homens contemporâneos? Se a resposta for positiva, as ideias e conceitos de natureza hoje se tornam ainda mais contraditórias. Qual o motivo que leva o conceito estético de natureza, nas culturas ocidentais, a considerar, mesmo a natureza transformada ou a natureza nas cidades, como uma natureza natural? Por que ao invés de ver e valorizar aquela natureza, ou aquele objeto, que insere uma naturalidade, como sendo produtos da inteligência e do trabalho do homem se valorizam as ideias e representações de natureza primitiva? Por que quase sempre quando se emprega o adjetivo natural institui-se uma aura pura à coisa ou produto e quando se menciona artificial, na maioria dos casos, vincula-se a uma referência pejorativa?

A lógica da natureza artificializada busca imitar e superar a natureza natural, a partir da imposição de certo rigor matemático, criando espaços da racionalidade. A diferenciação entre os lugares se dava de acordo com a natureza e hoje de acordo com o grau de tecnificação do território - neodeterminismo do espaço artificial?

\section{AS REFERÊNCIAS À NATUREZA}

A natureza é uma referência constante no dia a dia. Nas referências à natureza, encontram-se várias formas de "fugas", mesmo que simbólicas, do mundo. Segundo Soper (2000), a relação com os animais é um exemplo. Na antropomorfização dos animais, animais recebem traços da personalidade humana: a responsabilidade (o cão de guarda ou o cão pastor) ou a afetividade (o gato que tem amor a casa). Também recebem nomes humanos e são interlocutores de muitas conversas. Segundo Thomas (1996, p. 223), "a delicadeza com os animais era um luxo que nem todos tinham o direito a praticar" durante boa parte dos séculos XVIII e XIX. Dialeticamente, os homens também usam os animais para distinguir-se de sua própria animalidade. Assim, os animais passam a representar os homens com baixa inteligência (o burro), com falta de modos civilizados (o cavalo), ou com o excesso de peso (o porco, no caso do Brasil, ou a vaca para os norte-americanos). Os 
mesmos animais que são úteis à vida - em tarefas produtivas ou por simples razões afetivas - tornam-se bestas. Acrescenta Thomas (1996, p. 53) que na Idade Moderna e no início da Idade Contemporânea, a bestialidade dos animais poderia ser aplicada aos homens, "uma vez percebidos como bestas, as pessoas eram passíveis de ser tratadas como tal. A ética da dominação humana removida os animais da esfera de preocupação humana [as bestas deveriam ser exterminadas]. Mas também legitimava os maus tratos àqueles de viviam uma condição supostamente animal”.

Descobrir o grau de naturalidade de um objeto requer a compreensão de sua história e não apenas a observação de sua aparência, isto porque todas as sociedades por mais simples que sejam seu modo de vida - comparado com as civilizações ocidentais contemporâneas - desenvolveram processos de alteração, controle e domínio da natureza.

Considerando as características do período atual, dentro de uma sociedade de consumo, os objetos ou as mercadorias tornam-se os mediadores das relações entre o homem e a natureza. Estes objetos e mercadorias podem ser um simples creme dental com sabor natural; o papel higiênico natural (sem perfume) ou com perfume natural (com perfume de flores); o protetor de tela do computador com suas árvores de folhas vermelhas ou os peixinhos nadando; as árvores cercadas por uma tela com propaganda de supermercado; os lugares turísticos, onde se pode passear por praias desertas ou pelas trilhas ecológicas na mata; os condomínios de alto padrão nas cidades. Cabe destacar que não se busca impor uma mudança no uso da palavra natural no cotidiano, mas sim explorar suas ambiguidades, bem como desvelar seus usos.

De acordo com Santos (1994, p. 23), "se antes a natureza podia criar o medo, hoje é o medo que cria uma natureza mediática e falsa, uma parte da Natureza sendo apresentada como se fosse o Todo". Continua o autor (op.cit., p. 24),

quando o 'meio ambiente', como Natureza-espetáculo, substitui a Natureza Histórica, lugar de trabalho de todos os homens, e quando a natureza 'cibernética' ou 'sintética' substitui a natureza analítica do passado, o processo de ocultação do significado da História atinge o seu auge. É também desse modo que se estabelece uma dolorosa confusão entre sistemas técnicos, natureza, sociedade, cultura e moral.

A natureza se transforma num grande shopping center. Aliás, o maior shopping center do Brasil (Parque Dom Pedro, em Campinas) utiliza uma aproximação com a natureza para se diferenciar na concorrência, com direito ao portal das águas, das pedras, das colinas, das flores e até grama artificial. Talvez este centro comercial 
sintetize de maneira incisiva a ideia da apropriação e da comercialização da natureza no período atual: o marketing verde e a natureza enclausurada sob formas que dão a ideia de serem naturais, mas que na verdade são apenas falsificações.

É interessante notar que em muitos casos as referências à natureza se dão através de seus elementos de grandes proporções. A beleza da natureza residiria nas montanhas, nos rios ou mesmo nas árvores. Se esquece que, no período atual, aquilo que poderia ser considerado ainda como uma natureza primeira se esconde no meio das estruturas microscópicas, que o olho humano ainda não alcançou.

O mesmo se dá com a definição imposta de que toda a natureza é verde. Vários produtos quando querem mencionar algo natural sempre colocam a cor verde como representação da natureza. Nota-se que esta escolha pela natureza verde pode estar relacionada ao fato de que as plantas foram os elementos da natureza que mais se tornaram conhecidos, controlados e manipulados pelos homens ao longo de sua história, tanto de maneira empírica (primeiros cultivos) quanto através da ciência (botânica). Ou seja, a natureza representada pelas árvores e pelo verde é uma natureza já amplamente tecnificada que não apresenta riscos ao homem.

Esta natureza monocromática nada tem a ver com a variedade de cores que a natureza, em qualquer período, possui. A ideia de natureza que se apresenta hoje, relacionada à fluidez do mundo atual, contraditoriamente, remete a uma rigidez no seu padrão, a perda da especificidade e da diversidade.

Quanto maior o grau de humanização dos lugares e quanto maior sua inserção no projeto racionalista-capitalista de consumo, mais a referência à natureza se torna uma necessidade e uma estratégia de marketing. De acordo com Lefebvre (1973), na sociedade contemporânea quem mais compreende os homens não são os cientistas sociais e humanos, mas sim os publicitários. Estes que compreenderam as formas da transformação da necessidade, por exemplo, de respirar e beber água, em desejos. Assim, a natureza transformada em mercadoria rara passa, no mundo dos desejos, a ser consumida através de produtos exclusivos, como garrafas de água mineral de grife ou da busca por moradias em condomínios vinculados à natureza.

A natureza dentro das características do modo de produção capitalista, como da propriedade privada, tem construído uma interpretação da natureza, segundo Harvey (1996, p. 131), como um conjunto passivo de elementos a serem cientificamente acessados, usados e valorados em termos comerciais (dinheiro). De acordo com Lukács (1974), todas estas formas demonstradas de mediação social da natureza implicam na dissolução da natureza, tanto em sua forma como em seu conteúdo, em formas sociais que permitam a apropriação pela sociedade. 
A monetarização e mercantilização que atinge as ideias e conceitos de natureza sob o controle de capitalista, mostram, de acordo com Harvey (2000), uma organização material da produção, circulação e consumo que depende e reforça específicas noções de direito e obrigações. Afeta os sentimentos de alienação, subordinação e as concepções de poder. Mesmo aparecendo como novos caminhos da própria expressão (o multiculturalismo como o exemplo recente mais marcante) são cativos das forças da acumulação do capital. O amor à natureza elaborado como sinônimo de ecoturismo é uma das formas de mercantilizar a natureza.

No período atual, criam-se muitas metáforas da natureza, mitos de naturezas inexistentes, que representam um congelamento simbólico do natural. Na organizada feira de consumo da natureza, esta se transforma em mercadoria, vendida como autêntica ou mesmo como natureza "caricaturizada", "disneyficada".

\section{A 'DISNEYFICAÇÃO’ DA NATUREZA}

O capitalismo, segundo Harvey (1996), tem feito a natureza como ela é através de julgamentos estéticos, reações românticas, vegetarianismo, movimentos pelos direitos dos animais. Magnetizada a proteção da natureza através de desertos e preservação dos habitats, enclausurando-a em sentidos estreitos de natureza.

Considera-se que, apesar dos discursos presentes sobre a 'destruição' da natureza pelos agentes do capitalismo, devido às características de cada momento do modo de produção capitalista, se produza uma natureza particular e de interesse, sob a ótica do capital, daquele conjunto momentâneo das situações. Assim, o capitalismo não destrói a natureza, mas sim a transforma e a produz constantemente, na busca ininterrupta pelo lucro e pela valorização constante das mercadorias e dos objetos.

O conceito de "Disneyficação" da Natureza (Disneyfication of Nature), é muito interessante para analisar estes processos e foi desenvolvido pelo geógrafo David Harvey (2000). Foi definido pelo autor como um reencantamento da natureza já como um item de consumo e um objetivo central da mercantilização. Uma verdadeira "Disneyficação" das experiências de natureza.

A "Disneyficação", para Harvey (2000, p. 199), insere os seguintes aspectos:

1) uma suposta felicidade, harmonia e espaços sem conflitos - uma fuga para fora do mundo real;

2) uma construção feita para entreter; 
3) uma história inventada;

4) um cultivo de uma nostalgia de um passado mítico;

5) uma perpetuação do fetiche pela cultura da mercadoria;

6) um agregado de objetos e coisas de todo o mundo numa ideia de diversidade e existência multicultural, mesmo que tudo se dê na forma de compartimentos;

7) um lugar limpo, sanitarizado e mitologizado, esteticamente perfeito.

A relação cotidiana com a natureza, a prática social e as representações construídas, passam a ser povoadas por pensamentos, imagens, fantasias e desejos de uma natureza glamourizada e reificada, como um desenho infantil. Baudrillard (citado por HARVEY, 1996), fala numa redução dos processos da vida a algo que ocorre sobre uma tela de cinema e nada mais. Santos (2000a) também coloca uma situação próxima, afirmando que a natureza e os espaços da vida cotidiana estão repletos de artifícios e de significações não plenamente percebidas, que acabam por se configurar em uma sucessão de enganos. Em suas palavras "a natureza artificializada, instrumentalizada ao extremo, recusa-se a se deixar entender diretamente. Os homens não vêem o que enxergam" Santos (2000aㅗ p.51).

Para Harvey (2001), o fetiche pela imagem coloca num pacote algumas formas estéticas predefinidas, às custas de posições étnicas, justiça social e ambiental, igualdade econômica, racial e social, bem como de questões locais e internacionais de exploração tanto da natureza quanto da natureza humana.

Todo um mundo de objetos passa a ser produzido seguindo os ditames de uma ideologia, mais ou menos perceptível aos olhos incautos. Seguindo esta perspectiva de uma "Disneylândia da Natureza", os homens estão rodeados por objetos e formas, vinculadas simbólica ou fisicamente à natureza, mas que se constituem em objetos e formas artificiais. A partir destas experiências se controem pseudosrealidades. O desejo é a compreensão destes mecanismos produzidos pelos agentes do capitalismo na produção social da natureza.

A apropriação privada e praticamente individual, desvela as fortes ideologias presentes no processo, como a felicidade pelo consumo e a naturalização da vida cotidiana e dos processos sociais. É preciso enxergar além dos ditames da ideologia e da propaganda, materializada sob e nos objetos e formas presentes no espaço geográfico. Neste processo de produção de objetos cheios de simbolismo e ideologias, a propaganda adquire um valor muito grande. Para Santos (2000, p. 10), "pagamos para sermos enganados. Paga-se o processo de engano que acompanha e que precede a produção das coisas, das relações e das imagens". 
Soper (2000) coloca uma constatação interessante. A comida e o alimento são vistos como necessidades básicas e naturais, em oposição à, por exemplo, um vôo de avião. Entretanto, a produção de comida se dá em campos e em fábricas, produtos da mente humana. Além disto, a própria comida, ou a forma de se alimentar, foi moldada num processo de desenvolvimento histórico, criando dietas, por exemplo. Isto dificulta, no senso comum, distinguir os limites da natureza, pois, muitas vezes, vê-se na gôndola do supermercado uma batata frita sabor natural churrasco num tubo de papelão e tampa de plástico, e acredita-se que a batata, por ser um tubérculo, é natural e que sempre foi alimento para a humanidade. Esquecese toda a cadeia produtiva que vai desde o melhoramento genético da batata até a campanha publicitária para sua venda. Este último detalhe confirma a ideia de Marx (1999), que a produção cria a necessidade de consumo.

O reencanto do mundo ocidental com a natureza está associado a uma ideia ou um padrão de natureza moldado pelos interesses capitalistas. Sob a forma atual do capitalismo, o oferecimento de produtos e serviços para as classes com maior poder de consumo, coloca os homens muito próximos da natureza. Uma natureza retrabalhada sob a forma de uma segunda natureza, incorporada, produzida e vendida de acordo com as leis e desejos do modo de produção capitalista: o lucro, a propriedade privada, os fetiches e sensibilidades do mercado, bem como pela segmentação dos diversos ramos do mercado, quer seja sob o ponto de vista da renda quanto das "necessidades" e "desejos".

A natureza perde sua aura mitológica, torna-se para uma parcela da população, um objeto de consumo, uma mercadoria que, pela escassez, transfigura-se em mercadoria de luxo, produzida e consumida através de uma ideia utilitarista (física ou socialmente). Nos usos humanos da natureza, esta deixa de ser reconhecia como algo em si mesma, exceto em ocasiões de grandes eventos cataclismáticos, como a erupção de vulcão, uma tsunami. Todo o conhecimento humano produzido sobre o funcionamento da natureza, suas leis e movimentos, configuram-se como formas de dominação e utilização de suas potencialidades dentro do mundo do consumo ou dos meios de produção. Para Harvey (1973, p. 214), esta conceituação do mundo natural, no qual a natureza é vista como um "recurso" para o uso do homem, demonstra a concepção materialista da natureza no pensamento científico moderno ${ }^{110}$.

Além disto, as classes economicamente mais privilegiadas desenvolveram mecanismos de superar esta "alienação" com a natureza, desenvolvendo formas que supram os prazeres e valores estéticos da proximidade com a natureza, em um tipo de zona proteção da natureza. De acordo com Soper (2000), as sociedades que mais abusaram da natureza também foram aquelas que mais valorizam os caminhos na direção do artifício (reflorestamentos, estufas, entre outros), como tentativas de valorização da saúde e da qualidade de vida. 
Para as classes com maiores poderes de compra empregam-se uma imagem pastoril, uma imagem campestre ou qualquer imagem que evoque a natureza como a mais bem sucedida das convenções para incrementar os ganhos no mundo das mercadorias, desde a margarina até os carros. Para Ítalo Calvino (1994), a natureza é cada vez mais falsificada e está comprometida com os interesses do capital. Segundo Schmidt (1976), isto ocorre justamente porque o mundo trata o homem melhor como objeto de usufruto. O elogio da natureza assume um tácito caráter ideológico quando não se considera o aspecto da utilização imediata, como ocorre, por exemplo, em sua contemplação a partir do ônibus de turismo. Se a natureza cessa de ser matéria prima, tampouco necessita que se a adore.

Hoje a natureza (capitalizada e mercantilizada) tem seus consumidores, seus clientes, aqueles que a percorrem, compram e a consomem, literal e metaforicamente, símbolo, imagem, ícone, poder, qualidade de vida, qualidade ambiental e cidadania.

Parece estar próxima a ideia de Marx (1980), onde todo o mundo sensível também passa a ser produto da indústria, indo desde os objetos mais simplificados do uso corriqueiro até as máquinas mais complexas. A natureza é a base material transformada em extensão da vontade humana.

\section{A VALORIZAÇÃO DA NATUREZA}

De acordo com Marx (1980), o dinheiro se apropriou do mundo todo. A natureza passa a ser valorizada sob a ótica da propriedade privada. O modo de produção capitalista terminou por alienar o homem do produto de seu trabalho, do mundo dos objetos e da natureza. Além disto, acrescenta Harvey (1973, 1996), a natureza acaba por ser reduzida aos seus elementos mais simples. São naturezas enquadradas, individualizadas, particularizadas e isoladas como elementos fragmentados sobre os quais se dão os direitos da propriedade privada, da compra e da venda.

Neste processo de valorização da natureza, da natureza como recurso, o dinheiro se torna o padrão de avaliação do que a natureza pode oferecer. O preço é dado à seus elementos como coisas particulares: o ar, as árvores, a água. Segundo Harvey (1973), o mundo do mercado acaba por reduzir a natureza e o homem ao status de uma commodity ou mercadoria. O fetichismo da mercadoria e do commodity criando identidades relacionadas ao "eu sou o que eu posso comprar ou eu sou o que eu possuo"111. A valorização monetária da natureza reforça formas de valorar a natureza, tais como o romantismo, o esteticismo, o ambientalismo e o ecologismo ${ }^{112}$. 
Harmonia e equilîbrio; beleza, integridade e estabilidade; cooperação e ajuda mutua; crueldade e violência; hierarquia e ordem; competição e luta pela existência; caos e desordem passam a ser identificados como 'valores naturais'.

Mas será que estes valores de beleza, estabilidade e integridade, entre outros princípios morais e virtudes, são inerentes à natureza?

Harvey (1996), responde dizendo que não. Se estes valores residem na natureza não há formas científicas de se afirmar o que eles são, independentemente dos valores implícitos nas metáforas empregadas na montagem de linhas específicas de um questionamento científico. Assim, a definição de valores para a natureza liga-se aos homens e não a própria natureza bem como da ideia de uma vida em harmonia com a natureza. Como foi visto anteriormente, os homens primitivos e até mesmo algumas sociedades atualmente, vivem em constante luta contra a natureza para sobrevivência.

No caso do estudo realizado sobre a natureza e os empreendimentos imobiliários, observa-se o uso da ideologia para dominar os compradores de uma ideia de vida confortável dentro da natureza. Os clientes/consumidores/adoradores da natureza são dominados e não percebem que esta natureza vendida não passa de uma mentira, um engodo. Estes empreendimentos transformam, desta maneira, a natureza numa "coisa-mercadoria" onde estas passam a ter seu valor definido em função das ideologias impregnadas em seu conteúdo e aparência, "como se fossem sujeitos sociais dotados de vida própria (um apartamento estilo 'mediterrâneo' vale um 'modo de viver', um cigarro vale 'um estilo de vida', um automóvel zero km vale 'um jeito de viver', uma bebida vale 'a alegria de viver', uma calça vale 'uma vida jovem' etc. etc.).” (CHAUÍ, 1984, p. 57)

Em um primeiro momento da relação que estabelece entre a ideologia e a natureza nos empreendimentos é a do fetiche, num sentido quase religioso, definido por Chauí (1984), como uma "coisa que existe por si". O segundo momento marca a dominação das pessoas e a ideologia da vida na natureza se transforma num poder sobre os adoradores (da mercadoria) da natureza e da vida confortável e segura no seu interior ${ }^{113}$.

Este poder define-se pela situação econômica do grupo social e, no caso dos proprietários dos imóveis, numa forma de manutenção de seu poder político e cultural. Comprar, consumir e residir em um condomínio que preserva, protege e valoriza a natureza é um símbolo de status. Se o empreendimento receber uma certificação verde maior será o poder de sedução empregado para conquistar o comprador. A natureza agradece, memso estando confinadas em pequenos claustros e reduzida a alguns poucos exemplares de poucas espécies vegetais, na maioria dos casos, exóticas. 
A definição da natureza na cidade como uma mercadoria destinada a ratificar esta ideologia dominante implica a exclusão das classes economicamente inferiores do acesso à vida com a natureza. Legitima-se, no mundo das ideias e do mercado, a dominação ou a manutenção de privilégios. Enquanto as classes dominantes vivem com sua natureza enclausurada e controlada em seus jardins, nos bairros dos excluídos observa-se a natureza relegada "ao mato" ou "as enchentes" e, em muitos lugares, a total falta de qualquer natureza.

O conceito de "Renda de Monopólio", resgatado por David Harvey, também será útil para se entender o uso da ideia de natureza no mercado imobiliário. Segundo Harvey (2001), a renda de monopólio aplicada às relações de cultura, de estética, de valores afetivos, da vida social e do coração, pode parecer muito técnica e árida para carregar o peso das relações humanas além dos cálculos possíveis do financista, do incorporador, do agente imobiliário e do proprietário da terra. Continua o autor (op.cit.), que este termo busca os nexos entre a globalização capitalista, o desenvolvimento político-econômico local e a evolução dos significados culturais e valores estéticos. A renda de monopólio se realiza pelo desejo de grupos sociais em utilizar um item, direta ou indiretamente negociável, o qual é, em algum aspecto crucial único e não duplicável. Um recurso com qualidades especiais, commodities ou uma localização são exemplos de itens pelos quais as pessoas no mundo todo estão dispostas a pagar, a partir das taxas extras. Garantindo-se, assim, por um período longo de tempo o seu controle exclusivo.

Repete-se uma velha lei do mercado. A escassez de algum produto, no caso da natureza, faz seu preço aumentar. O mundo capitalista parece ver, nas palavras de Heidegger (citado por HARVEY, 2000), a natureza como um posto de combustível para a exploração humana.

Estes recursos podem ser apenas um recurso estético, um valor estético, materializado num lote, num vinho, numa pintura etc. A qualidade especial destes objetos pode ser tão única - ar puro, vista, tranquilidade - que é difícil de se atribuir um valor. Entretanto, a publicidade e a venda maciça de um produto ou de uma ideia por si leva a destituição desta aura de exclusividade que os cerca, tal como um lugar selvagem ou remoto, a pureza de alguma experiência estética da paisagem. O problema do capital é achar meios de cooptar, subjugar, mercantilizar e monetarizar tais diferenças para torná-las propícias à apropriação das "rendas de monopólio".

A constatação da instalação do consumo como a possibilidade de satisfação individual e como mediação entre o homem e o território (e com a natureza) é a grande perversão do período atual. A busca pela satisfação pessoal encerra um poder que transforma o cidadão em consumidor. Segundo Santos (2000a, p. 17), vêse uma glorificação do consumo na mesma proporção de uma glorificação do indi- 
vidualismo cruel e opressor, que destrói os traços da individualidade, da personalidade, levando assim a uma padronização do consumo, dos desejos e dos ideais. Instaura-se a perda da diversidade, que é uma das riquezas da vida em sociedade ${ }^{114}$.

Uma visão emancipatória, no momento histórico atual, nas relações da sociedade com a natureza é, portanto, um resgate do papel da coletividade perante a individualidade e o individualismo. Deve-se retomar os aspectos da produção e do uso da natureza para a satisfação coletiva. Resguardando as possibilidades deste uso não ao utilitarismo exacerbado que se assistiu nos últimos dois séculos de ação intensiva do modo de produção capitalista. Construir uma vida coletiva a partir das necessidades fundamentais da vida e da natureza coletivizada ${ }^{115}$. Nesta opção pelo coletivo, assistir-se-ia, segundo Santos (1997), a instauração de um Período Popular na História, que pode ser lido de acordo com a abordagem da emancipação coletiva. Neste processo, torna-se fundamental uma desfetichização do homem, entendido como o ato de revalorização do próprio homem e de seu trabalho, apagando qualquer traço dos símbolos que escondam a riqueza de sua ação. Considerar o próprio homem, a natureza e a cidade em razão de um valor de troca, conduzindo, portanto, a uma desfetichização do homem, do espaço e uma "desnaturalização" dos processos sociais é a possibilidade de transformar as relações atuais entre a cidade e a natureza em uma relação emancipatória. 


\section{NOTAS}

${ }^{97}$ Segundo Santos (1978, p. 163), "pela produção o homem modifica a Natureza Primeira, a natureza bruta, a natureza natural, socializando, dessa forma, aquilo que Teilhard de Chardim chama de 'ecossistema selvagem'. É por essa forma que o espaço criado como Natureza Segunda, natureza transformada, natureza social ou socializada. O ato de produzir é, ao mesmo tempo, o ato de produzir espaço”.

${ }^{98}$ Para Santos (1999, p. 88), as formas [e a natureza] por si só não participam do jogo dialético, "uma casa vazia ou um terreno baldio, um lago, uma floresta, uma montanha não participam do processo dialético senão porque lhes são atribuídos determinados valores, isto é, quando são transformados em espaço. O simples fato de existirem como formas, isto é, como paisagem, não basta. A forma já utilizada é coisa diferente, pois seu conteúdo é social. Ela se torna espaço, porque forma-conteúdo”. Já Bachelard (1983), faz uma crítica sobre as formas mais idealistas ou românticas de entendimento da natureza, pois estas não são as melhores opções para a compreensão da natureza. Segundo o autor (op. cit. 111), "quando um idealista estabelece uma filosofia da natureza, ele se contenta em por em ordem às imagens que ele faz da natureza, satisfazendo-se com o que estas imagens têm de imediato. Ele não ultrapassa os limites de um sensismo etéreo."

99 A natureza no período atual também pode ser entendida de acordo com a proposta de Bertrand (1978), como o universo físico transformado em sistema, ou fenomenologicamente, como escreve Merleau-Ponty (2000), definindo a natureza como vida e tudo aquilo que tem um significado não dado pelo pensamento humano. Para Merleau-Ponty (op. cit.), a natureza é tudo aquilo que é primordial, sem ser física ou mentalmente construída, como o solo, mas não aquilo que se vê e sim aquilo que é o suporte.

${ }^{100}$ Lenoble (1969, p. 205).

${ }^{101}$ Salienta-se que a provocação colocada por Milton Santos infelizmente foi incorporada por algumas correntes da Geografia "Humana", que, ao invés de discutir e aprofundar o debate sobre a natureza (atrelada a Geografia Física), optaram pela simplificação da ideia do fim da natureza, excluindo a natureza de suas análises.

${ }^{102}$ Para Schama (1996), a invenção do arado, como uma faca que ataca o solo, aumenta a produtividade agrícola e marca uma forma de libertação do homem do domínio da natureza. O desenvolvimento da técnica irá, de acordo com Fernández-Armesto (2001), permitir que o homem passe a encontrar a natureza através de suas técnicas e ferramentas. A natureza exteriorizada, tanto pela técnica quanto pela cultura, passa a ser objeto de exploração, como uma entidade exterior.

${ }^{103}$ De acordo com Santos (1994, p. 17), "a história do homem sobre a Terra é a história de uma ruptura progressiva entre o homem e o entorno. Esse processo se acelera quando, praticamente ao mesmo tempo, o homem se descobre como indivíduo e inicia a mecanização do Planeta, armando-se de novos instrumentos para tentar domina-lo. A natureza artificializada marca uma grande mudança na história humana da natureza. Hoje, com a tecnociência, alcançamos o estágio supremo dessa evolução”.

${ }^{104}$ Para Ortega y Gasset (1973), o destino do homem implica num gasto contínuo de energia, tendo que adaptar este mundo para suas necessidades constitutivas essenciais, as quais são precisamente aquelas pelas quais ele é inadaptado. Ele tem, então, que forçar a si mesmo para transformar este mundo que não coincide com ele, o qual é estranho para ele, o qual, consequentemente, não é ele. Ele precisa transformá-lo em outro mundo no qual seus desejos serão atingidos. O homem é um sistema de desejos que neste mundo são impossíveis. Portanto, para criar um outro mundo, a ideia do mundo deve coincidir, com seu desejo, isto é chamado de felicidade [...] Para transformar este mundo num outro mundo, que pode ser dele e coincidente, não existe outro instrumento que não o técnico. 
${ }^{105}$ Escrevendo a respeito das relações entre técnica e natureza no campo, Santos (1994, p. 143), escreve que "foi o período técnico-científico-informacional da humanidade, isto é, a possibilidade de inventar a natureza, de criar sementes como se elas fossem naturais, isto é, o progresso da biotecnologia, que permitiu, no espaço de duas gerações, que o que parecia um deserto [de gente e produção], como o cerrado, na região Centro-Oeste e na Bahia, se transformasse num vergel formado por um caleidoscópio de produções, a começar pela soja”.

${ }^{106}$ Pode-se pensar este controle, a dominação e a transformação da natureza pelo homem através de uma comparação com o ideal alquimista, trabalhada por Bachelard (1983, p. 68). "O alquimista procurava uma mudança de qualidades. Ele tentava, por exemplo, uma troca de cores, confiante no caráter substancial da cor. Que possa amarelar o chumbo, eis um primeiro sonho, eis um programa. Com uma semente cinza, com o germe do chumbo, que grande sonho conseguir amadurecer a substância e obter, concretizando as metáforas, amontoados de ouro. Mais profundamente ainda, se o trabalho alquimista pudesse tornar pesado o chumbo, se o chumbo pudesse ficar tão pesado quanto o ouro, a transmutação estaria muito perto de ser bem sucedida!". Este sonho de transformação da qualidade das coisas em algo que é útil e valioso ao homem é um sonho e uma busca antiga da humanidade.

${ }^{107}$ Pode-se citar o exemplo do lago formado na construção de uma barragem para uma usina hidrelétrica. Muitas vezes o lago em si é visto como algo natural, quando na verdade possui uma naturalidade, a água, pela sua estrutura molecular, mas como forma, aparência e função, é algo completamente construído pelo homem.

${ }^{108}$ Diferentes culturas têm algumas particularidades no entendimento da natureza. Férnadez-Armesto (2001, p. 10), dá um interessante depoimento de como diferentes culturas lidam com a natureza. Os ingleses, supostamente preferem a natureza à cultura, com seu gosto pela vida no campo, esportes rurais, cirurgia veterinária, caminhadas em sob qualquer tempo e jardins, que imitam uma paisagem natural. Mas esta natureza é uma natureza enquanto ideia. É uma metáfora que remete a um ideal romântico, pois todas estas atividades ligadas à natureza são enquadradas dentro de uma cultura refinada. Muitas vezes, esta mesma natureza, é vislumbrada a partir de uma janela, de um quadro ou separada por um muro.

$109 \mathrm{Na}$ pesquisa de mestrado sobre a Ilha Comprida (litoral sul do Estado de São Paulo), Henrique (2000) constatou que todo apelo as 'belezas naturais intocadas' do lugar e a possibilidade de se colocar fora da agitação dos grandes centros urbanos não conseguiu, no fluxo de turistas, superar a realidade do isolamento do lugar, do difícil acesso e da falta de infra-estrutura. Somente quando um trecho da rodovia BR 116 foi duplicado, uma ponte ligando a Ilha Comprida ao continente foi construída, as redes de água e esgoto chegaram às casas, é que se observou um crescimento urbano impulsionado pelo turismo.

110 "This conceptualization of the natural world, in which nature is viewed as a 'resource' for the use of man, underlies the materialist conception of nature in modern scientific thought". (HARVEY, 1973, p. 214).

${ }^{111}$ Harvey (2001, p. 278/279)

${ }^{112}$ A valorização da natureza também é um processo historicamente datado, conforme mostra Abreu (1992, p. 55), "[...] a relação entre natureza e sociedade é sempre historicamente determinada. Em outras palavras, o significado e o valor que uma sociedade atribui aos elementos da natureza irão sempre variar no tempo, acompanhando o processo histórico de seu desenvolvimento econômico e social. Valores ambientais que são hoje tão disputados pela população do Rio, como viver próximo à praia, por exemplo, seriam considerados extremamente exóticos (ou mesmo irracionais) pelos cariocas do passado".

113 "O mundo se transforma numa imensa fantasmagoria". (CHAUÍ, 1984, p. 57) 
${ }^{114}$ Esta constituição de um individualismo exacerbado produzirá uma dependência do consumidor ao novo mundo dos objetos, o que "limita sua vocação para obter uma individualidade e reduz a possibilidade dos encontros interpessoais diretos e enriquecedores, porque simbólicos em sua própria origem. A comunicação entre as pessoas é frequentemente intermediada por coisas. [...] A socialização capitalista, originária da divisão de trabalho que a monetarização acentua, impede movimentos globais e um pensamento global. A reivindicação de uns não raro representa um agravo para o outro. A força da alienação vem dessa fragilidade dos indivíduos, quando apenas conseguem identificar o que os separa e não o que os une".

115 Segundo Santos (1979, p. 291), deve-se colocar a produção a serviço da humanidade, do coletivo, sendo "necessário, antes de tudo, que a ideia de produtividade econômica ceda lugar a ideia de produtividade social. As tecnologias teriam então um papel subordinado. O crescimento não teria sentido se não estivesse a serviço de todos. A procura do lucro apagar-se-ia diante das preocupações com a equidade. O consumo não seria mais comandado pelas necessidades do aparelho produtivo, mas este seria ordenado em função de um consumo cuja definição coincide com o bem estar coletivo". 

PARTE II

A NATUREZA NA CIDADE E SUA APROPRIAÇÃO PELOS EMPREENDIMENTOS IMOBILIÁRIOS 



\title{
VI - A NATUREZA NA CIDADE
}

\begin{abstract}
Uma cidade!
É o domínio do homem sobre a natureza. É uma ação humana contra a natureza, um organismo humano de proteção e de trabalho. É uma criação. A poesia é ato humano - relações harmoniosas entre imagens perceptíveis. A poesia da natureza é, exatamente, apenas uma construção do espírito. A cidade é uma imagem poderosa que aciona nosso espírito. Por que a cidade não seria, ainda hoje, uma fonte de poesia?
\end{abstract}

Le Corbusier, 2000

A cidade, seu espaço e suas relações com a natureza, tem suscitado muitas observações contraditórias ou convergentes, pessimistas ou otimistas que merecem uma reflexão.

O momento histórico atual pode ser considerado como o período das cidades, e, de acordo com Robert Park (1936 apud HARVEY, 1973, p. 195), a cidade é o habitat natural do homem civilizado. Léfebvre (1969), afirma que o urbano agora domina a sociedade industrial. Para Harvey (1973), a cidade é um grande sistema, um grande recurso, é até mesmo uma negação da natureza, uma vez que, se trata em grande parte de algo feito pelo homem. "Despindo a roupa da Natureza e vestindo a da Técnica, a Cidade, coisa inteiramente histórica, impõe a ideia de um tempo humano, um tempo fabricado pelo homem" (SANTOS, 1994, p. 82). Na mesma direção Sergio Buarque de Holanda (1969, p. 61) coloca que a moradia nas cidades é completamente antinatural, na medida em que é o resultado de um processo mental e intencional dos grupos humanos em oposição a vida em natureza. Completa ainda que "para muitas nações conquistadoras dos territórios no Novo 
Mundo, a construção de cidades foi o mais decisivo instrumento de dominação que conheceram" Holanda (1969, p. 61).

O cotidiano da grande cidade faz com que, para Rodrigues (2001), a natureza seja vista como fonte de "recuperação das energias". Mesmo nesta proximidade da natureza, como forma de "renovação" na vida estressante e rápida da cidade, muitos elementos da natureza precisam ser apagados, mascarados e escondidos. Rios e outros corpos d'água são canalizados e avenidas são construídas nos fundos dos vales, pensando-se apenas na fluidez do trânsito. As áreas verdes são substituídas por áreas densamente edificadas ${ }^{116}$.

Nas cidades, num primeiro momento, a natureza apresentava-se como um elemento estético. Era uma forma dada que caracteriza a paisagem urbana. A natureza também colocava uma necessidade de adaptação por parte da cidade, como no caso do Rio de Janeiro e seus "pães-de-açúcar" e morros; ou Salvador e seu plano de falha que corta a cidade em dois patamares, como mostra Santos (1965).

Analisando as relações entre a cidade, a montanha e a floresta no Rio de Janeiro, Abreu (1992) apresenta uma interessante análise das relações entre a cidade e a natureza no Brasil. Na sua apresentação, o autor (op.cit.), afirma que, no Rio de Janeiro, a sociedade e a natureza formam um todo indissociável e difícil de ser separado. No caso da floresta urbana da Tijuca, ela "é ao mesmo tempo natureza e história, ou melhor, é natureza com história”, em função do processo de reflorestamento da área no século XIX, como uma forma de garantir o abastecimento de água na cidade que sofria com a escassez hídrica ocasionada pela secagem de várias nascentes na Tijuca com a substituição da vegetação nativa pelo cultivo do café.

Infelizmente, a natureza na cidade, cujo elemento caracterizador será a vegetação, está confinada no desenho urbano a uma espécie de metonímia da natureza. Uma natureza racionalizada (em diferentes gradações), uma natureza construída, não uma representação direta da natureza, mas sim um modelo de natureza historicamente construído pela técnica, pela ciência, pela cultura, pela prática e pela ideologia.

A natureza se insere na cidade através dos jardins e praças, lugares para reis e nobres, para a aristocracia e burguesia. Só recentemente a população urbana se encontrará com a natureza na cidade através dos jardins e parques públicos, mas ainda pouco acessíveis para todos. A disposição destes jardins e parques públicos no espaço intra-urbano atende as lógicas da especulação imobiliária e da renda. Mesmo cidades brasileiras com áreas verdes consideráveis apresentam uma concentração destas áreas nos bairros nobres. Na maioria dos bairros da periferia social e de ocupação popular, altamente adensados, são inexistentes áreas públicas verdes e de lazer ${ }^{117}$. 
Se no senso comum e em algumas correntes epistemológicas, a natureza se opõe à cultura e à história, o que se vê nas cidades hoje é exatamente o contrário. A natureza se insere na cidade como produto da história, da evolução das ideias e conceitos que foram sendo criados, da história das técnicas e da cultura consumista que se estabelece.

Segundo Capel (2002), as primeiras formas de incorporação da natureza à cidade remetem ao início das aglomerações humanas, como em Susa (3000 a.C.), onde os bosques sagrados já faziam parte integrante dos templos. Nas primeiras cidades, a natureza estava atrelada às questões de ordem religiosa e não apenas estética, e remetiam a uma ideia de paraíso terreno. Já em Roma e na Grécia foram desenvolvidas, respectivamente, formas de integração entre a natureza e a arquitetura urbana, valorizando os aspectos estéticos, como a arte da topiaria (desenho de figuras sobre uma base vegetal) e a construção de jardins integrados aos edifícios.

$\mathrm{Na}$ Idade Média, os jardins ${ }^{118}$ transformam-se em hortas nos conventos e mosteiros. Como escreve Capel (2002), em Florença, no século XIV, havia um jardim (horta) no centro da cidade escondido por muralhas. Este referido horto (jardim + horta) teve grande influência na estruturação do espaço urbano, refletindo-se na nomenclatura das vias de circulação, como as vias del'Orto ou dell'Ortone.

No Renascimento retomam-se os ideais humanistas, materializados em uma imitação da natureza nos jardins. Desenvolvem-se as ideias da tranquilidade do campo dentro das cidades. Entretanto, apesar de se buscar a simplicidade da natureza, os homens do Renascimento acabam por aumentar a artificialidade e a complexidade da natureza na cidade, criando e revalorizando novas formas de incorporação da natureza.

\section{DO JARDIM FORMAL AO JARDIM INGLÊS - A NATUREZA TOMA SEU LUGAR NA CIDADE}

O Renascimento marca uma remodelação geral das cidades européias, até então marcadas por um desenho urbano medieval. Este "planejamento urbano", na Idade Moderna tinha como objetivo ordenar as intervenções urbanas, racionalizando o espaço urbano "caótico" das vielas estreitas e do adensamento das construções. Por racionalização do plano urbano compreende-se a substituição das linhas curvas do traçado das cidades pelo desenho retilíneo ${ }^{119}$.

Segundo Capel (2002), foi Leon Battista Alberti, em sua obra De Re Aedificatoria ( A Arte de Edificar), quem difundiu a utilização da vegetação com apelo estético nas cidades européias do início do século XVI. Repetia-se constantemente em várias 
cidades o modelo do Belvedere de Bramante, de 1503, com um palácio situado ao pé de terraços, rampas e escadas simétricas numa forma cenográfica articulada em patamares. O jardim se converte numa construção. A arquitetura supera a natureza; e o agradável (belo) supera o útil ${ }^{120}$.

A nobreza européia que se enriquecia, incentivava a criação de parques, que eram, segundo Segawa (1996), bosques cercados para a caça. Estes parques anexos às propriedades foram sendo incorporados aos padrões estéticos da burguesia como sinônimo de valorização econômica e símbolo de status. Em Antuérpia, 1569, surge a primeira praça com árvores na Europa (Place Verte ou Groenplaats), ao lado de uma catedral. Ainda neste momento, a valorização imobiliária do entorno da praça se dava em função da igreja e não pelas árvores (o plantio de árvores ainda não havia se popularizado nas cidades européias) ${ }^{121}$.

A natureza na cidade brasileira apresenta algumas particularidades, oriundas desde sua fundação pelos portugueses, com grandes diferenças entre as cidades criadas em outras partes da América ${ }^{122}$. Em uma abordagem largamente difundida nos estudos sobre as cidades construídas nas Américas por espanhóis ${ }^{123}$ e portugueses, Holanda (1969, p. 62), alertava que o desenho das cidades das áreas de ocupação Espanhola demonstra uma característica de superação das imposições do sítio, levando a construção de ruas e formas de ocupação que evidenciavam o esforço na retilinização dos arruamentos e na terraplanagem do terreno, "as ruas não se deixam modelar pela sinuosidade e pelas asperezas do solo, impõem-lhes antes o acento voluntário da linha reta”. Já a colonização portuguesa não seguia estas normas e as cidades acabam por se acomodar de acordo com o sítio, afirmando que a "cidade que os portugueses construíram na América não é produto mental, não chega a contradizer o quadro da natureza, e sua silhueta se enlaça na linha da paisagem." (p. 76) ${ }^{124}$

Já na Europa, com os descobrimentos de novas terras, os jardins botânicos passam a exibir espécies exóticas do Novo Mundo. Desenvolvem-se, desta maneira, os conhecimentos naturalistas e da botânica, através da aclimatação e cruzamentos de espécies (novamente a ação do homem na melhora da natureza). A natureza na cidade, materializada nos jardins, transforma-se em lugar de exibição, em uma espécie de museu. Os jardins transformam-se em jardins botânicos ${ }^{125}$.

Os jardins, cada vez mais elaborados e organizados, tornam-se lugares de ostentação e riqueza, em detrimento das ideias de simplicidade e de rusticidade. Segundo Capel (2002), os jardins urbanos consagram o triunfo da arte e do artifício sobre a natureza ${ }^{126}$.

Os jardins urbanos também se tornam lugares privilegiados nos desenhos dos planos urbanos. O plano urbano ortogonal e a geometria cartesiana marcam a 
geometrização da natureza na cidade. Desenhando e construindo jardins, os arquitetos foram se atrevendo a moldar e transformar a natureza de forma cada vez mais ousada. Se constroem os jardins barrocos, nos quais se corrige e embeleza a natureza e, usando a geometria, a retifica para produzir efeitos surpreendentes ${ }^{127}$.

Nas cidades, os jardins também passam a se aproximar das casas. De acordo com Capel (2002), na Veneza do século XVI, configuram-se as villas italianas, que marcavam uma primeira forma de "cidade verde", com a valorização de uma vida urbana que simulava uma vida campestre. Tais "villas" tornam-se moda e, posteriormente, lugares de refúgio da nobreza veneziana.

No século XVII, os jardins urbanos e seus entornos convertem-se em parques, com predomínio das árvores plantadas regularmente de maneira ortogonal. Nas áreas anexas aos palácios, como Versalhes, a natureza ortogonal e controlada representa o ápice do conhecimento botânico e estético da época, refletindo uma construção total da natureza (jardins) em função da imaginação e criatividade humana, conforme escreve Capel (2002). O jardim francês é a forma máxima da expressão humana geometrizada, à qual está submetida à natureza na cidade. Segundo Capel (2002), a mensagem de que a natureza está subjugada pela arte é expressa através do desenho de jardins. A remoção de terras, as obras hidráulicas e os desafios aos climas, através das "orangeries" ou estufas, entre outros trabalhos, mostram de forma eminente o poder do homem. É a culminação de séculos de evolução ${ }^{128}$.

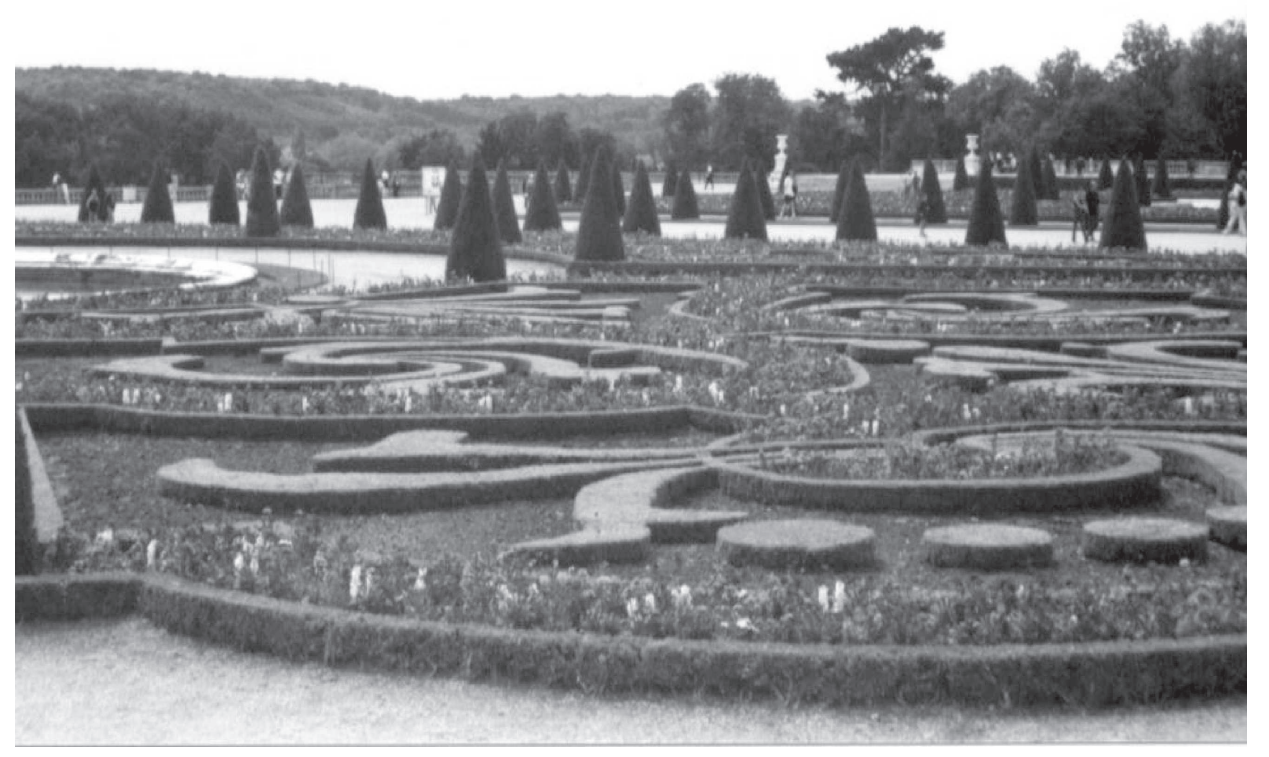

Jardins de Versalhes. Destaque para as formas geométricas do jardim. 
O jardim formal, ou francês, expressa o poder sobre a natureza e também o poder político absolutista. Na construção dos jardins as formas geométricas seriam superiores àquelas deixadas no seu curso natural. Nestes jardins predominam as linhas retas, com desenho ortogonal e algumas diagonais. Até os lagos seguem um modelo geométrico simétrico. As árvores e os arbustos também são modelados/ podados em volumes geométricos, reforçando a arte da topiaria e o modelamento da vegetação aos caprichos e vontades dos homens.

Como os jardins reais e aristocráticos passam a ser moda na Europa Ocidental, cria-se uma necessidade de aumento destes espaços nas cidades. Os jardins passam a ser lugares de passeio e de encontro. Tornam-se locais para a comparação e competição social entre as pessoas, bem como para "desfiles de moda e poder"129. Acentua-se o caráter de poder social do jardim na cidade ${ }^{130}$.

Os jardins urbanos, passeios públicos e parques - "salões de festa" fora dos palácios - incorporam-se ao planejamento urbano e tornam-se uma constante nos planos de melhoria urbana, como na região do Champs Elysées ${ }^{131}$, em Paris.

Nos limites das cidades, em razão da disponibilidade de terrenos, construíram-se passeios arborizados, com jardins e edificações para abrigar salões de festas. Por iniciativa dos poderes públicos, estas áreas se configuraram, em muitas ocasiões, como estímulos à expansão urbana, tornando necessária a quebra dos limites impostos pelas antigas muralhas.

Além do "Champs Elysées" de Paris, pode-se citar o "Parque del Prado", em Madri, criado em 1780, nos limites da cidade, que consistia num conjunto de Passeio-Salão - Boulevard-Gabinete de História Natural e o Jardim Botânico. Também começa, no século XVIII, a abertura dos parques reais para a população, estes localizados geralmente no centro das cidades. Munford (1998) cita: o St. James e o Green Park em Londres; as Tulherias em Paris; o Tiergarten em Berlim.

No âmbito filosófico, as ideias do Iluminismo (século XVIII) tiveram desdobramentos na criação destes parques e espaços verdes urbanos. A natureza na cidade reafirma-se como um elemento estético. Os plantios de árvores nas cidades seriam de grande utilidade, mesmo com aqueles tipos de vegetação com função apenas decorativa. Segundo Jovellanos (1782, apud CAPEL, 2002) as árvores também poderiam ter uma função recreativa, e seu plantio nas bordas dos caminhos, nos parques e nas vias das cidades, seria de grande beleza cênica. Era necessário, portanto, que se iniciassem imensos plantios de árvores nas cidades.

Estes imensos plantios de árvores nos espaços urbanos não seriam possíveis sem os avanços da botânica na aclimatação de espécies exóticas e no desenvolvimento de novas plantas mais adaptadas às características das cidades. As formas 
urbanas e os edifícios passam a incorporar estes ideais de melhoria, correção e transformação da natureza.

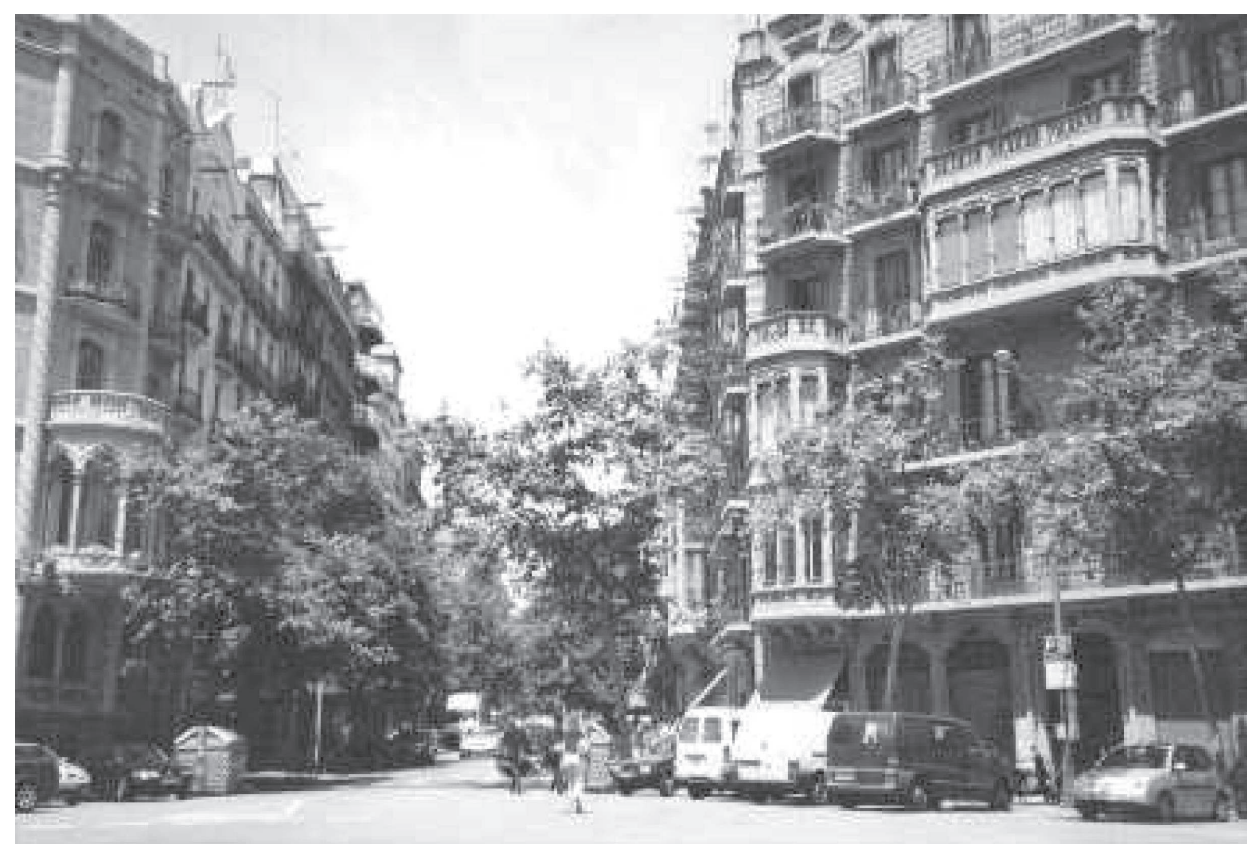

Bairro residencial de Barcelona, cidade com grande arborização urbana fruto de iniciativas empreendidas em meados do século XIX.

Nas cidades do século XIX, o jardim formal começa a sofrer a concorrência com a construção de jardins que buscavam a imitação da natureza, os jardins ingleses. Enquanto o jardim formal francês privilegiava a geometria e a subordinação da natureza às formas, o jardim inglês pregava a ideia da natureza em estado puro e livre.

Estas duas visões da natureza na cidade, de acordo com Capel (2002), estarão ligadas diretamente aos embates entre duas visões de mundo. De um lado o cartesianismo francês e de outro o pragmatismo e empirismo inglês. O jardim francês na cidade era a materialização do poder absolutista da monarquia. Já o jardim inglês, na cidade, irá concretizar as ideias da liberdade e democracia, bem como do liberalismo econômico.

O jardim inglês exaltará a natureza não contaminada pelo homem, uma natureza em estado natural, vai representar a valorização dos ideais gregos. Ocorre uma (re)naturalização do jardim em linhas curvas, buscando uma simplicidade e nostalgia de um passado épico. A elaboração dos jardins em estilo inglês pressupõe uma 
atitude menos dominadora perante a natureza, ou seja, constrói-se um espaço que parece ser natural.

A natureza do jardim inglês é uma natureza idealizada a partir da eleição de elementos do seu conjunto que irão representar o todo. Serão operadas correções em aspectos "feios" dos elementos desta natureza idealizada. Nos parques urbanos serão construídos lagos e grutas com linhas curvas. Estas formas constituem-se em um simulacro da natureza primeira, que há muito deixou de existir. O jardim inglês é a materialização de um conceito de beleza estética e uma representação cultural estética e ideologicamente definida. Como todo jardim, trata-se de um espaço modelado pela ação humana, mas vinculado à ideia romântica da natureza intocada ${ }^{132}$.

A criação dos jardins em estilo inglês trouxe à cidade uma valorização da paisagem rural e a construção de casas que mais pareciam casas de campo. Estas casas que se proliferam eram sempre baseadas em um parc ou park ${ }^{133}$. Tais casaspark eram acima de tudo lugares de "prestígio e privilégio" da burguesia e nobreza inglesas e buscavam ser o elo entre as virtudes do campo e a vida social da cidade. Resgatavam-se ideais como a valorização da caça e a importância dos bosques e dos rios nas propriedades. As propriedades menores, que também buscavam demonstrar esta inspiração bucólica, introduziram o garden (jardim) em seu nome.

No Brasil, é criado no século XVIII, mais precisamente em 1783, o Passeio Público do Rio de Janeiro. O jardim passa a ser um importante elemento na vida social da cidade, recebendo constantes melhoramentos e monumentos imponentes. O Passeio Público se configuraria como um monumento à vegetação e à natureza na visão de Segawa (1996), mas também ao poder da burguesia e nobreza carioca, uma vez que ser tornou rapidamente o lugar de passeio e exibição destas camadas da população.

Entretanto, a natureza tropical sem manutenção retoma rapidamente sua 'selvageria'. No século XIX, a falta de público, devido à concorrência com outras áreas verdes do Rio Janeiro, faz com que o Passeio Público entre em decadência e o dinheiro para sua manutenção acabe. Escreve o prussiano Lydwig von Rango (1819 apud SEGAWA, 1996, p. 99) que

tudo o que a natureza faz por este país é magnificente, por isto parece tanto mais pobre o que o homem criou. Estou vindo do Passeio Público, o único em todo o Rio. Que Deus tenha misericórdia! Nem um caminho seco em todo o jardim [...] Realmente uma lástima, um lugar tão bonito e bem arborizado, que se poderia tornar realmente belo com pequeno custo. Mas assim é tudo aqui. Nada se faz com cuidado, tudo se deixa largado à lei da natureza. 
No Rio de Janeiro, a vegetação dos morros que circundam a cidade é uma "natureza avassaladora", onde a falta de técnicas e seu constante controle são um entrave à sua domesticação.

Sobre a natureza no entorno das cidades brasileiras, escreve a inglesa Maria Graham (1821, Diário de uma Viagem ao Brasil, apud SEGAWA, 1996, p. 75) que

\begin{abstract}
os cafezais são os únicos terrenos cultivados na redondeza e são intercalados tão densamente com laranjeiras, limoeiros e outros arbustos, que parecem antes uma variedade das matas do que a mescla de terreno cultivado com o terreno selvagem, que seria de esperar tão perto de uma grande cidade, onde contamos ver o trabalho humano aplicando-se razoavelmente sobre a beleza rude da natureza. Mas aqui a vegetação é tão exuberante que até as árvores podadas e tratadas crescem como se fossem na floresta.
\end{abstract}

A autora ainda fala que a natureza mantida "selvagem" tira metade do seu encanto.

Não basta uma moda de jardim para mudar o desenho do espaço urbano. Para que isto se implemente definitivamente, é preciso que se crie um sistema de ideias que permita esta constante remodelação. Não se pode mais tratar o espaço com a rigidez dos tempos passados e valorizar menos a história dos lugares com a destruição de sítios antigos.

\title{
A NATUREZA NA CIDADE COMO ATRATIVO IMOBILIÁRIO
}

No século XIX inicia-se um movimento mais intenso de associação entre a natureza na cidade e a especulação imobiliária, com a construção de jardins e parques pelos agentes imobiliários tendo como objetivo a valorização dos loteamentos e das edificações construídas no entorno. A natureza na cidade passa a ser uma "isca" ou uma imagem/símbolo para atrair os compradores, em um momento de grande valorização da natureza na cidade, quer seja por motivos estéticos (os passeios e a exibição de poder) ou por razões higienistas ${ }^{134}$ (de saneamento da cidade cada vez mais poluída pelas indústrias).

Neste momento da história das relações entre a cidade e a natureza, Reclus (1886) coloca duas formas de apropriação da natureza pelos empreendimentos imobiliários: uma direta e outra indireta. A apropriação direta da natureza, cada vez mais artificial, se dá, como exemplo, nas áreas costeiras, nos "pitorescos penhas- 
cos" e nas "praias charmosas" que tem seu uso e acessos monopolizados pelos proprietários destas áreas, chamados por Reclus de "invejosos", bem como pelos agentes especulativos da terra que "apreciam a beleza da natureza" da mesma forma que um cambista aprecia uma barra de ouro, ou seja, apenas como forma de realização monetária. A apropriação direta da natureza está presente também nas áreas de lagos, montanhas e demais paisagens valorizadas, em um determinado momento, fazendo que a natureza, materializada na paisagem, se torne propriedade privada, negando o caráter coletivo da produção e incorporação da natureza na vida social $^{135}$. Já a maneira de apropriação indireta da natureza dá-se na forma de sua utilização para a venda de produtos. Segundo Reclus (1886), prédios e propagandas ocupam áreas de grande beleza paisagística natural como formas de venda de mercadorias, produtos e serviços.

$\mathrm{Na}$ associação entre especulação imobiliária e a natureza, os incorporadores se apropriam de todos os locais charmosos e belos, dividindo-os em lotes retangulares, enclausurando os mesmos em muralhas uniformes onde são construídos mansões e casarões pretensiosos. Para os que passeiam pelos caminhos e trilhas, nestes pretensos espaços de campos, a natureza não é mais do que representada por arbustos talhados e amontoados de flores que são entrevistas através das grades (RECLUS, 2002).

Será em Londres que primeiro se observará estes processos de apropriação e vinculação do mercado imobiliário de terras urbanas com o processo de valorização imobiliária a partir de uma associação com uma ideia de natureza. No início do século XIX a transformação das terras do Royal Marylebone Park num parque urbano - o Regent's Park. Todo o modelamento e estruturação deste parque que foi financiado pelas empresas imobiliárias londrinas, cujo objetivo era a construção de casas no entorno deste novo parque. Casas com vistas e terraços e "villas" para pessoas ricas. A ideia era que a venda das casas nas proximidades do parque pagaria os investimentos gastos no Regent's Parks. Segundo Munford (1998), na área do atual Regent's Park, que antigamente pertencia à Igreja Mary-le-Bow, estava sendo prevista a construção de um cemitério. Entretanto, o crescimento da cidade e a possibilidade de realização de lucros prevaleceram sobre o uso que se daria à área, que foi, portanto, loteada. "Quando a Coroa planejou o Regent's Park de Londres, o próprio parque foi abertamente considerado um artifício para aumentar o valor dos terrenos de propriedades vizinhas, pertencentes à Coroa Real." (p. 414)

Isto num momento de crescimento das cidades e enriquecimento de uma parcela da população urbana, que comprava terras, construía vilas e casas com jardins, aquecendo o mercado imobiliário que soube aproveitar esta demanda pelo contato com a natureza na cidade. Deve ser lembrado que as cidades euro- 
péias viviam uma acelerada industrialização e a poluição atmosférica era uma constante. A ideia do verde na proximidade das casas trazia um alívio contra esta poluição.

A apropriação da natureza, uma apropriação da apreciação estética da natureza, constitui-se em uma salvaguarda das suas belezas como forma de agregação de valor a uma propriedade privada. Cria-se uma diferenciação espacial da natureza na cidade de acordo com a estratificação social. Nos centros urbanos e nos bairros nobres o que se via era uma natureza trabalhada e bem cuidada - tanto no jardim inglês quanto no francês, um lugar para passeio e exibição, um lugar de prestígio. Nas periferias, ainda no modelo clássico de periferia pobre, a natureza bruta e ainda "não controlada", fazia-se presente, trazendo enchentes, inundações, doenças e frio ${ }^{136}$.

Desenvolvem-se tentativas de saneamento desta natureza bruta para evitar a contaminação e a proliferação de doenças na população. Na Alemanha aparecem as primeiras tentativas de popularização dos parques e jardins da cidade, dando origem aos Volksparken (parques populares).

Segundo Capel (2002) o conceito de parque público também surgiu como resposta para os problemas sanitários das cidades industriais européias, fixando a ideia da necessidade dos parques e jardins nas cidades européias do século XIX. Na reforma de Paris por Georges Haussmann, entre 1853-1870, foram adaptados 1.934 hectares de áreas verdes na cidade por motivos estéticos e sanitários, como na criação de parques periféricos.

Neste movimento foi criado o Bois de Boulogne, cuja área foi doada a cidade por um empreendedor imobiliário, que era proprietário das terras do entorno do parque. As colinas e lagos artificiais, construídos seguindo o modelo inglês, tornaram o lugar numa área de sucesso junto à alta burguesia e aristocracia parisiense. Logo entrou "na moda", valorizando imensamente o seu entorno (para reforçar, do mesmo proprietário das terras doadas para a construção do parque), que foi vendida como "o céu para os ricos"137. Do lado oposto à cidade de Paris foi criado o Bois de Vincennes, destinado a ser o parque das camadas populares. Entretanto, como as classes populares trabalhavam em média 12 horas por dia, não tinham tempo livre para frequentar estes parques.

Outro plano de reforma urbana importante para visualizar o papel que a natureza na cidade teve foi o desenvolvido por Idelfonso Cerdá, na Reforma de Barcelona em 1859. O objetivo era dar viabilidade e habitabilidade à cidade catalã. O lema de Cerdá era urbanizar o campo e ruralizar a cidade. Esta ideia também está presente no Manifesto Comunista, escrito por Marx, e publicado inicialmente em 1848. 
Em relação à natureza na cidade, Cerdá, segundo Capel (2002), considerava que o jardim é tão necessário a cidade quanto à família ao homem, sendo um lugar indispensável na vida urbana, uma necessidade para todos. Para Cerdá, a natureza na cidade (principalmente as árvores) também tem a função de renovar o ar, cada vez mais poluído e carregado de doenças, sendo observada uma constante falta destes espaços nas áreas pobres e nos bairros de classe média de Barcelona.

Nos Estados Unidos, graças a George Marsh, assiste-se a um grande processo de valorização da natureza a partir do século XIX. São criados os Parques Nacionais (como o Yosemite Valley). Já os parques urbanos começam a ser esboçados em 1851, quando se inicia o plano para o Central Park, em Nova Iorque. Nos Estados Unidos é dada ênfase aos parques em estilo inglês, vinculado as ideias estadunidenses de liberdade e democracia, com forte valorização da natureza local, através do plantio de árvores do próprio lugar. Em Nova Iorque ${ }^{138}$, a especulação imobiliária no entorno do parque também se apropria das referências à natureza, levando a super adensamento das áreas próximas.

Como as propagandas de empreendimentos imobiliários da atualidade (que serão analisadas no próximo capítulo), em 1866, no Plano de Riverside, Illinois (EUA), a Riverside Improvement Company já fazia menção a sofisticação da natureza na cidade. Como mostra Capel (2002), a propaganda de Riverside mostra o encanto refinado da beleza silvestre com paz e tranquilidade, positivamente pitoresco e que contrasta com os ângulos retos que caracterizam as cidades modernas ${ }^{139}$.

Uma constatação do século XVIII, a mudança das formas prioritárias das relações sociais, deslocando-se da esfera coletiva para uma valorização do indivíduo, assenta-se efetivamente no século XIX sobre todos os aspectos da vida social.

Observa-se uma expansão dos jardins, praças e parques arborizados em várias cidades. Na maioria das cidades, que foram desenhadas e planejadas a partir das ultimas décadas do século XIX, foram previstos espaços para jardins públicos nas áreas centrais, com o predomínio do estilo inglês. Estas novas cidades e estes novos espaços verdes estavam vinculados ao aumento da preocupação com o prático e o funcional. Além disto, aumenta o número de grupos sociais mais abastados, vivendo exclusivamente nas cidades, que assimilaram os gostos da aristocracia pelos jardins. A classe média, em formação, também se preocupará em manter seus jardins particulares nas residências menores.

De acordo com Capel (2002), o subjetivismo romântico alia-se, no século XIX, às necessidades da produção industrial em massa, considerando-se as necessidades do mercado, que passa a valorar os gostos individuais dos consumidores, um gosto que era diferenciado. Desde o século XIX já não basta o verde. A industrialização e a democratização demandam também novos espaços para o ócio. [...] Nos 
jardins e parques começam a ser instalados elementos que logo seriam denominados "mobiliário urbano"140 - bancos, quiosques, fontes, sanitários etc. Logo foi percebido que os parques eram um grande negócio: lugares de passeio e de diversão (zoológicos, brinquedos etc.) ${ }^{141}$.

\section{AS FORMAS DO URBANISMO E A QUESTÃO DA NATUREZA NA CIDADE}

A estruturação dos parques urbanos começa a ser um forte exemplo para o planejamento de todas as cidades. O objetivo era levar beleza às mesmas. Assim, no século XIX, o desenho dos jardins formais chega às cidades. Como exemplo, Capel (2002), cita o plano urbano de La Plata (Argentina).

O urbanismo "Beaux-Arts" é uma das correntes que irão procurar entender a cidade como jardim ou parque, criando espaços monumentais, praças, eixos viários, principais e secundários, com bosques. No centro desta cidade haveria um grande espaço equivalente ao palácio no jardim clássico. O desenho urbano vai assimilar a questão da simetria do jardim formal, elaborando uma hierarquização dos espaços da natureza na cidade através de uma geometria rígida.

Fundamentado nas questões higienistas e no urbanismo "Beaux Arts", o plano de Belo Horizonte, no final século XIX, já previa um grande parque público verde na área central. Segundo Segawa (1996, p. 70), "a árvore se tornava um símbolo de civilidade, de cultura, de patriotismo". Nesta direção, foram criados o Dia da Árvore, mais outros projetos de reflorestamentos (baseados no reflorestamento do maciço da Tijuca) e planos de arborização urbana.

O planejamento urbano difunde as ideias de claridade e espaços abertos do higienismo ${ }^{142}$, mas também retoma o rigor geométrico e a monumentalidade das formas. Nas cidades cresce os usos da topiaria, com o modelamento de arbustos em figuras geométricas simples, especialmente, retângulos, cones e esferas.

O número de habitantes nas casas também é reduzido, permitindo que seja liberado terreno no lote para a construção dos jardins, que antes de ser uma determinação estética era uma questão de posição social. Segundo Capel (2002) ter um jardim não era apenas um luxo nas casas da burguesia urbana, mas um indicador de status.

A associação cada vez maior entre casa e jardim e as experiências bem sucedidas em Londres, na área do Regent's Park (onde se tinha à ilusão de que o parque pertencia a cada casa) e Paris no entorno do Bois de Bologne, com grande êxito financeiro, impulsionam o interesse pelas áreas verdes urbanas atreladas aos gran- 
des empreendimentos imobiliários. A ampliação das áreas verdes nas cidades deuse, portanto, devido ao grande prestígio e valor que estas passaram a ter.

$\mathrm{Na}$ Inglaterra, o problema da salubridade das moradias populares se agrava. Com a ideia da higienização da natureza e sua função estética no embelezamento da cidade, começa a se desenvolver um projeto de aproximação definitiva entre a natureza e o plano urbano - as cidades-jardim. O desenho urbano respeitava a dimensão humana e evidenciava as ideias inglesas de natureza.

O slogan das cidades-jardim era: "Para cada família uma casa; em cada casa uma horta e um jardim". O modelo das cidades-jardim foi desenvolvido por Ebenezer Howard (1850-1928), e se constituiu num novo modelo de organização urbana. Segundo Howard (1996), o homem deve desfrutar ao mesmo tempo a sociedade e as belezas da natureza.

O plano das cidades-jardim era um complexo modelo com forte relação entre a cidade e o campo. Na cidade-jardim, a natureza domesticada desempenharia o papel do campo, trazendo a tranquilidade e o ar puro necessário à vida urbana saudável. Foi projetada como núcleos urbanos com 30.000 habitantes na cidade e 2.000 no campo. As cidades-jardim seguiriam um modelo de cidade radiocêntrica. Estava planejada uma grande rede interna de infraestrutura e de comunicação com outras cidades. As cidades-jardim não seriam apenas o lugar da moradia, mas também previa a instalação industrial. A propriedade seria comunal e não privada.

Em 1900, foi fundada a primeira cidade-jardim - Letchword (entre Londres e Cambridge), que só manteve parte da proposta morfológica, urbanística e dos jardins que existiam na proposta inicial. Esta cidade não materializou todas as propostas básicas da cidade-jardim de Howard (1996), de uma cidade orgânica em harmonia com a natureza - base da felicidade humana. A rica vegetação da cidade-jardim era composta por árvores frutíferas, flores e legumes. ${ }^{143}$

As críticas ao modelo das cidades-jardim eram baseadas na rigidez do plano urbano não adaptado ao sítio; nas moradias quase idênticas; na distância entre a moradia e o local de trabalho, pois poucos postos de trabalho foram criados no entorno da cidade; na fraca relação social entre os moradores; na desvalorização dos espaços públicos, uma vez que, no espaço familiar já havia um jardim.

Na Alemanha, com o crescimento das cidades, há também um aumento da demanda por moradias, com a construção de blocos de moradias na periferia das cidades projetadas como cidades-jardim. Entretanto, há uma explosão demográfica da cidade planejada para um número pequeno de habitantes. Na Alemanha, após a Primeira Guerra Mundial, os jardins foram transformados em hortas para a produção de alimentos, garantindo a subsistência das famílias (CAPEL, 2002). 
Na Exposição Universal de Paris, em 1900, foi recomendado que toda cidade reservasse $15 \%$ de seu espaço total para a criação de jardins e parques. Posteriormente, os Congressos de Higiene Urbana, em Paris e Berlim, elaboraram textos visando à proteção da natureza na cidade como forma de garantia da vida saudável.

As propostas de intervenção urbana passam a contar com um aumento da participação do Estado no planejamento. Antes limitado a coadjuvante do capital privado, o Estado passa a elaborar regulamentações sobre moradia e edificações (principalmente a altura dos novos arranha-céus que se difundiam mundo afora a partir dos Estados Unidos) e infra-estrutura (herança higienista).

Em 1924, ocorre em Amsterdã o Congresso Internacional de Planejamento Urbano, cujo objetivo era o desenvolvimento de formas de organização das funções e do espaço urbano, através da elaboração de planos de expansão urbana e zoneamento das cidades (definição de áreas centrais, zona industrial, zona de lazer, zona residencial).

Na Europa, várias cidades passam por grandes alterações no período entre as Guerras Mundiais, tais como:

- rápido crescimento das cidades;

- desenvolvimento das indústrias - localização das áreas urbanas ou periferia das cidades;

- necessidade de organização das atividades urbanas e dotação de equipamentos urbanos em maior número e em maior velocidades;

- novos desenvolvimentos técnicos e científicos - aperfeiçoamento do telefone;

- comércio;

- revoluções no mundo das artes - cubismo, impresionismo, expressionismo;

- aumento da frota de veículos.

Em razão destas rápidas transformações, os trabalhos de Le Corbusier e as novas formas de urbanismo passam a defender uma interação cada vez maior entre a moradia, a oferta de serviços e o local de trabalho. O urbanismo racionalista começa a desenvolver blocos de moradias em bairros residenciais, com a utilização de novos materiais e novos elementos para construção rápida, como janelas préfabricadas e portas. As linhas de produção - fordismo e taylorismo - chegam com força total à cidade. 
Como para Le Corbusier a cidade-jardim e a forma como a cidade estava sendo pensada, conduziria a um isolamento, ao individualismo e a paralisia da coletividade, buscava-se desenvolver um novo modo de planejamento, atrelando a cidade à natureza. Segundo Munford (1998), a ideia de Le Corbusier era a construção de uma Cidade-Jardim Vertical, a fim de liberar espaço para áreas verdes ${ }^{144}$.

Mas não bastava apenas a presença da natureza na cidade, era preciso ordenar o aspecto caótico da natureza. As árvores, plantadas em parques e jardins, também teriam uma função subjetiva, ajudando a superar a individualidade egoísta e trazendo bem estar físico ${ }^{145}$.

Para Le Corbusier (2000), tendo em vista a intensificação do trabalho, haveria uma maior exigência de calma e ar puro. Devido ao aumento da mancha urbana, consequentemente com a derrubada das árvores (pulmão da cidade), o urbanismo deveria possibilitar:

- a elaboração de medidas de conservação das áreas verdes nos centros da cidade e nas periferias;

- o aumento considerável da densidade de áreas verdes - chegando a 95\% em algumas áreas;

- a verticalização dos centros para a liberação de espaço para áreas verdes;

- a construção de apartamentos com janelas afastadas das ruas, voltadas para parques extensos e possuindo amplas sacadas - para melhor circulação do ar e entrada da luz. Em tais sacadas (alvéolos) seriam criados grandes jardins internos.

Em 1933, Le Corbusier sintetiza na famosa Carta de Atenas, os resultados do Congresso Internacional de Arquitetura Moderna - CIAM, cujos princípios norteadores eram:

- a busca de garantias de salubridade, de áreas verdes, de sol e ar puro, de contato com a natureza como forma de recuperação das forças gastas no trabalho;

- uma cidade planejada não apenas na escala local mas também regional, nacional e internacional;

- a necessidade de conservação destas áreas, uma vez que, o aumento das áreas urbanas sempre ocorre em detrimento das áreas verdes; 
- a retomada das questões coletivas sobre as individuais - do público sobre o privado;

- a abundâncias de áreas verdes e construção vertical numa área mínima do terreno.

Entretanto, as novas estruturas familiares, cada vez menores, e a super valorização do indivíduo acaba por implodir os ideais de Le Corbusier. No Pós Guerra, alguns pontos elaborados por Le Corbusier, são observados na construção de conjuntos residenciais nas cidades novas.

Mas o que se constata é a deterioração das áreas verdes. O abandono e a falta de manutenção fazem com que estes espaços sejam visto pelos moradores, como sinônimo de lugares perigosos e violentos. A natureza na cidade sem controle e sem manutenção retoma a sua imagem de perigo e o seu aspecto hostil. O jardim bem cuidado acaba por se transformar em mato.

Desenvolvem-se também formas de um urbanismo naturalista, cuja maior expressão foi o americano Frank Lloyd Wright. Para Wright (apud CHOAY, 1992, p. 30), "a grande cidade industrial é acusada de alienar o indivíduo no artifício. Só o contato com a natureza pode devolver o homem a si mesmo e permitir um harmonioso desenvolvimento das pessoas como totalidade".

Infelizmente, mesmo com todas as utopias do urbanismo moderno, a cidade e a natureza passam a ser, segundo Rodrigues (2001, p. 213), "medidas e mediadas pelo valor de troca, incessantemente alterado no processo indissolúvel" e a volta do verde à cidade é uma forma de apropriação da natureza como propriedade privada.

A natureza na cidade é uma necessidade, que infelizmente foi engolida e propagada pelas possibilidades de consumo da moradia. As necessidades estão sendo criadas de acordo com a renda do comprador dos imóveis. Assim, a natureza na cidade torna-se uma mercadoria para poucos consumidores, escolhida em função do aumento do valor de troca dos empreendedores imobiliários. Para os agentes do mercado imobiliário, a natureza na cidade não é uma necessidade coletiva, e a exclusão é exercida a serviço da acumulação. 


\section{NOTAS}

116 Carvalho (2003, p. 10), escreve que "na cidade, ambiente artificial por excelência, onde a natureza quase que só está presente sob a forma antrópica, as características naturais do sítio sobre o qual se estabeleceu só são lembradas para a explicação da gênese dos problemas ambientais urbanos."

${ }^{117}$ Para Saldanha (1993, p. 63-64), a natureza na cidade, em jardins ou praças, "veio representando uma gradativa diminuição do papel (ou da presença) da natureza: aqui o termo natureza é usado no seu sentido mais concreto, incluindo animais e arbustos, embora sem excluir a relação com um significado mais profundo. E parece que este gradual cancelamento da natureza, em seus componentes mais concretos, se faz mais perceptível, senão mais ostensivo, no caso da praça. Ou seja, nas representações da dimensão pública, inclusive nas ligadas ao poder: edificações, ornamentação, linguagem de símbolos."

${ }^{118}$ Vale lembrar a origem da palavra "jardim" (jardin, garten, garden), segundo Capel (2002), vem do germânico gard, que significa 'cerca' ou 'paliçada'.

${ }^{119}$ Cabe destacar que o traçado reto do plano urbano representava a vontade de conquista e dominação do sítio. Sobre as linhas retas e curvas na cidade, escreve Le Corbusier (2000, p. 6-7), que "o homem caminha em linha reta porque tem um objetivo; sabe aonde vai. Decidiu ir a algum lugar e caminha em linha reta. A mula ziguezagueia, vagueia um pouco, cabeça oca e distraída, ziguezagueia para evitar grandes pedregulhos, para se esquivar dos barrancos, para buscar a sombra; empenha-se o menos possível. O homem rege seu sentimento pela razão; refreia os sentimentos e os instintos em proveito do objetivo que tem. Domina o animal com a inteligência. Sua inteligência constrói regras que são o efeito da experiência. A experiência nasce do labor; o homem trabalha para não perecer. Para produzir é preciso uma linha de conduta; é preciso obedecer às regras da experiência. É preciso pensar antes no resultado. A mula não pensa em absolutamente nada, senão em ser inteiramente despreocupada."

120 "El jardín se convierte en una construción en donde la arquitectura supera la naturaleza" (CAPEL, 2002, p. 232). "En el jardín domina lo agradable sobre lo útil." Capel (op.cit., p. 246).

${ }^{121}$ Capel (2002).

${ }^{122}$ Além destas particularidades, nascidas junto com as cidades brasileiras, outras especificidades se apresentam. Outra grande distinção diz respeito à diferenciação entre o jardim (a mais comum representação da natureza nas cidades européias) e a praça - a materialização da natureza nas cidades do Brasil. Desta forma, a proximidade com a natureza e o caráter público ou privado do espaço - praça ou jardim - são importantes elementos usados para esta diferenciação. Segundo Saldanha (1993, p. 37), "sem dúvida o jardim concentra e registra a privacidade retendo uma porção da natureza, enquanto que a praça vem a ser um espaço aberto na natureza, senão contra ela. Um espaço muitas vezes tido como sagrado (morada de um deus, com seu templo), quase como um modo de compensar a violência, ou a violentação, que o origina. Na verdade, o jardim também é cultural, e o que se tem são dois modos de ser das relações entre o homem e o mundo." Continua o autor (op.cit., p. 63), "o advento da praça corresponde, mais do que ocorre com o jardim, a uma eliminação da natureza. Ou antes a um corte, uma abertura nos espaços naturais, feita na verdade pelo próprio fenômeno da cidade, que se instaura como um outro tipo de espaço dentro dos espaços físicos disponíveis no vale ou na montanha. O jardim reformula a natureza, operando uma redução ou uma seleção quanto às espécies vegetais e ao seu arranjo, em convívio com canteiros, muros, colunas, estátuas [...]; o jardim a reformula, defendendo-a como ao próprio sentido de privacidade que nele se recolhe. A praça, parâmetro das ousadas coordenadas urbanas, se recorta como um outro espaço, não natural, onde o que há de árvores e de flores é expletivo e complementar, embora às vezes pareça esteticamente essencial." 
${ }^{123}$ Como escreve Segawa (1996), as cidades espanholas da América repetiam os modelos dos ejidos (campos verdes) e alamedas (ruas arborizadas) - com uma significação estética. Já as cidades portuguesas desenvolviam os rossios (hortas), cuja finalidade era, principalmente, a produção de alimentos.

${ }^{124}$ Esta ideia de Holanda (1969) sobre a inexistência de uma racionalidade na construção das cidades pelos portugueses foi debatida por Nestor Goulart Reis Filho, pois a adaptação do plano urbano ao sítio pode ser considerada uma forma de ocupação pensada e racional. Além disto, a própria escolha dos sítios em acrópole evidenciam um planejamento da ocupação em função dos aspectos de segurança e proteção contras invasões e ataques.

${ }^{125}$ Inicia-se os processo de valorização das plantas na cidade ou no seu entorno. Criam-se espaços de coleção de espécies, primeiramente os jardins reais - símbolos do poder e do conhecimento de um reino. Como exemplo, cita-se os Jardins Reais da França, posteriormente comandados por Buffon, hoje 'Jardin de Plantes', localizando numa área densamente povoada próxima ao centro de Paris. Sobre esta ideologia do melhoramento visível na natureza no século XVII, escreve Willians (1989 apud SEGAWA, 1996), "que agora que o homem produzia sua própria natureza por meios físicos de melhoramento (terraplanagem com novas máquinas, drenagem e irrigação, bombeamento de água para locais elevados), quer pela compreensão das leis físicas da luz e das perspectivas e pontos de vista artificiais, fatalmente teria de modificar-se a decoração, de um simbolismo e iconografia limitados e convencionais, da terra imediatamente visível."

126 "consagran el triunfo del arte y del artificio sobre la naturaleza”. (p. 236)

127 "Diseñando y construyendo jardines los arquitectos se fueron atreviendo a moldear y transformar la naturaleza de forma cada vez más osada. [...] Así se hace en los jardines barrocos, en los que se corrige y "hermosea la naturaleza y en la que usando la geometría, se la rectifica para producir efectos sorprendentes." (CAPEL, 2002, p. 254)

128 "Así se crea el modelo del jardín a la francesa, donde la naturaleza está totalmente sometida a la voluntad del hombre. El mensaje de que la naturaleza ha sido subyugada por el arte es explícitamente expresado a través del diseño de jardines en donde la remoción de tierras, las obras hidráulicas, el desafío al clima a través de orangeries e invernaderos y otros trabajos muestran de forma eminente el poder del hombre. Es la culminación de dos siglos de evolución." (p. 255)

${ }^{129} \mathrm{O}$ individualismo e a ostentação de riqueza e poder tomam definitivamente posição de destaque nos jardins. Como fala Munford (1998, p. 377), no século XVII o "pior de todos os pecados, é o pecado do orgulho, que tornou-se símbolo dos novos líderes da sociedade, tanto no escritório de contabilidade como no campo de batalha. Produzir riqueza, tomar e aumentar o poder, tornaram-se imperativos universais; tinham sido desde muito tempo praticados, mas agora abertamente admitidos, como principais orientadores de uma sociedade inteira".

130 "El juego de la autoidentificación, como individuo y como miembro de la sociedad, actúa como un imán para esta exhibición”. (RABREAU, 1991 citado por CAPEL, 2002, p. 250)

131 As ideias desenvolvidas nos planos de reforma urbana da região do Champs Elysées de Paris repercutiram de tal maneira no imaginário urbano que grande parte das cidades brasileiras, num período posterior buscaram criar seus "Campos Elíseos".

${ }^{132}$ Segundo Segawa (1996, p. 49), o jardim "torna-se um monumento ao verde - espaço ao culto e ao repositório de significados da natureza idealizada pelo ser humano." No âmbito do planejamento urbano, o jardim inglês possui um desenho que libera a natureza dos limites impostos no jardim formal.

${ }^{133}$ Segundo Capel (2002), um "park" era um pedaço do terreno com um bosque fechado, para as criações de animais. 
${ }^{134}$ Sobre as intervenções higienistas na cidade ver Benjamin Ward Richardson (Hygeia: A City of Health, 1876), cujas principais ideias, segundo Choay (1992) eram:

- menor mortalidade possível nas cidades;

- aumento das áreas verdes e jardim nas cidades como forma de terapia e também como áreas de lazer.

135 Segundo Munford (1998, p. 461), "a cidade, desde o princípio do século XIX, foi tratada não como uma instituição pública, mas como uma aventura comercial privada, a ser afeiçoada de qualquer modo que pudesse aumentar a rotatividade e fazer subirem ainda mais os valores dos terrenos".

${ }^{136}$ A moradia dos trabalhadores é constantemente comparada "com covis, as grandes distâncias que separam o local de trabalho do de habitação ('a metade dos operários do Strand já estão obrigados a caminhar duas milhas para chegar ao trabalho', constata Marx), os lixões fétidos amontoados e a ausência de jardins públicos nos bairros populares. A higiene moral também é considerada: há contraste entre os bairros habitados pelas diferentes classes sociais, chegado à segregação, fealdade e monotonia das construções 'para o maior número'." (CHOAY, 1992, p. 06)

Sobre este tema também deve ser mencionado o texto de Engels sobre a situação da classe trabalhadora na Inglaterra.

137 Capel (2002).

138 Segundo Munford (1998, p. 463-464), "o desejo de utilizar todos os metros quadrados de espaço alugável dominava o proprietário, mesmo quando a construção era para seu uso privado e não se destinava à simples especulação pecuniária. Em muitas cidades, durante o século XIX, isso reduziu o quintal dos fundos a uma área para secar roupas, e esta, por sua vez, foi reduzida em espaço, a tal ponto que muitas caras residências da Quinta Avenida, em Nova Iorque, eram construídas quase costas contra costas, como qualquer asilo de classe inferior, e não tinham nem perspectiva, nem ventilação. Mais uma vez, a empresa capitalista, hipnotizada pela sua própria preocupação com os ganhos, ultrapassava a si mesma, pois um plano congestionado não traz necessariamente o máximo de retorno imediato, nem tem probabilidade de permanecer bastante válido ou atraente para assegurar uma exploração lucrativa durante um longo período de anos."

139 Sobre a especulação imobiliária atrelada à natureza na cidade brasileira, pode ser citado o caso de Porto Alegre, no final do século XIX e começo do XX, com a criação do Campo da Redenção, seu ajardinamento e loteamento do entorno. Segundo Segawa (1996, p. 218), "aproveitamento de áreas tradicionalmente tidas como inúteis ou de árduo aproveitamento sobre várzeas, charnecas, terrenos de altimetrias complicadas. Era a conquista da terra firme, aterros que acresciam à vizinhança urbana horizontes de expansão, enterrando miasmas e cobrindo superfícies infectas com um simulacro saudável de natureza. Terrenos outrora sem préstimo, os quais, mediante intervenções patrocinadas pelo poder público - nem sempre adequadamente amparado com recursos para iniciativas dessa escala [diferente da Europa e dos EUA onde a intervenção no jardim era privada] (e sempre oficial, qualquer que seja a instância: autoridade colonial, provincial, municipal) - transformam-se em áreas valorizadas e vizinhanças valorizadas.”

140 "Desde el siglo XIX ya no basta el verde: la industrialización y la democratización han hecho necesarios también nuevos espacios para el ocio. [...] En los jardines y parques donde comienza a instalarse elementos que luego serían denominados "mobiliario urbano". (CAPEL, 2002, p. 318)

${ }^{141}$ Sobre os jardins zoológicos, escreve Munford (1998, p. 413-414) que "tinha-se aí uma nova contribuição à cidade: um lembrete daquele estado indômito que o homem urbano muito facilmente esquece, na ilusão de que conquistou com êxito a natureza. As atitudes divertidas do macaco, a imperturbabilidade do hipopótamo, os movimentos ágeis e alegres das focas - todos estes exemplos da inexaurível criatividade da natureza, se não puseram o morador da cidade em contato com ela, pelo menos tiveram um efeito relaxante sobre o ultra-restringido ego urbano. [...] Até mesmo sovadas relí- 
quias barrocas tais como o urso dançarino ou o macaco do tocador de realejo serviam muitas vezes para dar um toque de graça animal às tristes sarjetas da rua do século XIX".

${ }^{142}$ Os ideais higienistas e o medo das populações mais abastadas do Rio fizeram com que a população do centro da cidade (infestado de doenças e cortiços) e graças à facilidade do transporte, transferissese para Santa Tereza, em busca das terras altas com melhores climas e salubridade, conforme explica Abreu (1992). As árvores seriam peças fundamentais para manter a salubridade das cidades - eliminação dos "tóxicos pulmonares". Começam a proliferar a criação de jardins nos centros das cidades Em 1880, são criados os Campos de Sant'Ana e a Praça da Aclamação, no Rio de Janeiro.

${ }^{143}$ No Brasil, alguns bairros da cidade de São Paulo, como o Pacaembu, Jardim Europa, Jardim América e Jardim Paulista foram planejados como cidades-jardim. Atualmente, nestes bairros de São Paulo, onde a natureza era abundante, a violência urbana e o medo coletivo fazem com que se proliferem altos muros e complexos sistemas de segurança. A pressão sobre os preços dos terrenos e das moradias também provoca profundas mudanças nas funções antigas destes bairros, com muitas residências sendo convertidas em clínicas médicas e lojas sofisticadas.

${ }^{144}$ Em uma fachada de um prédio, Le Corbusier (2000) apresenta uma estrutura intercalada com grandes alvéolos vazados entre os andares cujo objetivo era facilitar a penetração da luminosidade solar, a circulação do ar possibilitando a presença de um jardim suspenso em cada sacada. Em 2004, na cidade de São Paulo, um edifício de alto padrão foi lançado seguindo esta proposta de Le Corbusier, entretanto, ao invés de vários alvéolos o projeto previa apenas um.

145 Segundo Le Corbusier (2000, p. 71), "pode caber ao novo espírito de arquitetura, ao urbanismo iminente, satisfazer às mais remotas necessidades humanas, reverdecendo a paisagem urbana e mesclando ao nosso labor a natureza [aforismo turco: onde construímos, plantamos árvores. Em nosso país, nós os arrancamos. Istambul é um pomar, nossas cidades são pedregais]." (p. 71) Segundo Choay (1992, p. 191), "a natureza é de novo levada em consideração. A cidade, ao invés de tornar-se um pedregal impiedoso, é concebida como um grande parque. A aglomeração urbana é tratada como uma cidade verde. Sol, espaço, zonas verdes. Os imóveis surgem na cidade por trás do rendado de árvores. Está assinado o pacto com a natureza”. 



\section{VII - UM BOSQUE PARA CHAMAR DE MEU. A APROPRIAÇÃO DAS IDEIAS DE NATUREZA PELOS EMPREENDIMENTOS IMOBILIÁRIOS}

A relação cotidiana com a natureza na cidade, como foi demonstrada nos capítulos anteriores, passa a ser povoada por pensamentos, imagens, fantasias e desejos de uma natureza "glamourizada" e reificada como um desenho infantil. Chega-se a um momento onde a economia, ou melhor, o estilo de vida capitalista irá pautar a superexploração da natureza na cidade.

Nesta relação, os homens não enxergam os fenômenos sociais, políticos ou econômicos que penetram na ideia de natureza. Preferem continuar a ver apenas uma imagem romântica da natureza, que é captada e apropriada pelos empreendimentos imobiliários nas grandes cidades.

Neste mundo da fantasia e da exploração capitalista, muitos empreendimentos imobiliários reforçam um processo de associação com uma das várias ideias possíveis de natureza na atualidade. Em comum, todos eles utilizam a natureza como uma das principais armas para sua valorização. Destacam-se, neste capítulo, alguns destes empreendimentos localizados nas cidades de São Paulo/SP e Florianópolis/SC e Salvador/BA, analisados a partir de materiais de propaganda, impressos e digitais, em cadernos e sítios da Internet especializados em imóveis das áreas estudadas. Salienta-se que não se buscou fazer um estudo quantitativo destes empreendimentos, mas sim apresentar de maneira qualitativa, a profusão desta apropriação ideológica da natureza na cidade.

De maneira geral, na apropriação ideologizada da natureza no mercado de imóveis inserem-se os seguintes elementos:

- Material de propaganda com uma super valorização da natureza, com predominância dos tons de verde;

- Os símbolos preferenciais para confecção dos logotipos são: as folhas, o sol, as árvores, as borboletas, as flores e as conchas; 
- Erros de localização e falta de escala nos croquis de localização;

- Abundância de praças e áreas verdes dentro dos empreendimentos;

- Privatização da natureza na cidade, materializada nos parques e praças públicos;

- Relação com uma natureza padronizada globalmente, sempre verde;

- Consumo da natureza como um objeto raro, privativo, requintado e exclusivo para as classes de alto poder econômico;

- Segregação urbana e a venda da ideia de natureza verde, mas associada ao conforto da vida citadina e suas possibilidades de consumo nos shopping centers.

Em relação aos slogans nas propagandas dos empreendimentos imobiliários, destacam-se:

- Praça exclusiva e privativa, garantido acesso total a natureza;

- O privilégio de possuir a natureza dentro do condomínio;

- Uma vida saudável na cidade em meio à natureza;

- Diferenciais únicos: natureza, ar puro e elegância; tudo isto pertinho de Shoppings e dos mais modernos serviços;

- Você vai querer criar raízes;

- A natureza e a segurança nunca estiveram tão próximas;

- Um estilo de vida que valoriza a natureza e o charme;

- A natureza toma conta do condomínio;

- Venha fazer parte de um seleto grupo que valoriza morar bem em contato com a natureza;

- Uma proposta moderna de integrar a natureza ao edifício;

- A vegetação nativa recebeu cuidados especiais;

- A natureza transformada em arte;

- A natureza fez o projeto para você;

- Uma área reservada para sua família e para a natureza;

- Lotes junto à natureza;

- Mais do que morar é viver; condomínio sofisticado em meio à natureza. 


\section{SÃO PAULO - A SOFISTICAÇÃO DA NATUREZA}

A cidade de São Paulo apresenta-se, esteticamente, como uma negação da ideia de natureza romântica e verde. Entretanto, encontram-se reunidos em seu espaço, os traços de uma ideia de natureza romanticamente e globalmente padronizada pelos agentes do mercado imobiliário, notadamente as grandes incorporadoras, que têm reafirmado o valor monetário da natureza. A valorização da natureza verde restringe-se apenas aos folhetos e material de propaganda, pois o que se observa na realidade é uma retirada da vegetação nativa (o que ainda restava) e, em outros casos, a manutenção de uma área verde na qual foram plantadas espécies exóticas - principalmente eucaliptos e palmáceas.

Em São Paulo, qualquer objeto associado a uma ideia de natureza torna-se sinônimo de qualidade de vida e transforma-se em valor econômico, aumentando os preços dos apartamentos, casas e edifícios. Este processo pode ser observado em várias áreas da cidade, com especial concentração nas imediações dos parques urbanos e em bairros como Vila Andrade (Panamby), Moema, Morumbi, Brooklin Novo, Campo Belo, Granja Julieta, entre outros. Os nomes que mais são mencionados nos empreendimentos pesquisados são: Villagio, Jardin, Parque, Villa, Village, Bosque.

Muitos são os empreendimentos que negam a construção social da natureza e todo o processo histórico de sua incorporação à vida cotidiana (como foi detalhado na primeira parte deste livro). Como, por exemplo, um edifício localizado no Itaim Bibi, onde seria possível conviver com a vegetação nativa/original do sítio. Após todo o processo de ocupação da cidade, de todo o desenvolvimento técnico da sociedade ocidental, encontrar verde nativo das matas brasileiras num bairro completamente urbanizado de São Paulo, com uma área verde por habitante, segundo dados do Atlas Ambiental de São Paulo (2003), de 3,86 m²/habitante, não é apenas uma ilusão, como se transforma no mais puro ato enganador que o "marketing verde” propaga. É a comprovação da alienação que falava Chauí (1984) e Santos (1994), do pagamento por um produto caro - a natureza nativa - mas que na verdade é o pagamento para ser enganado.

Outros casos se relacionam com o hiperdimensionamento das matas. Algumas árvores ou capões de eucaliptos e bambus se transformam em bosques naturais, que ocupariam bairros e condomínios inteiros.

Em São Paulo, as áreas verdes públicas da cidade se tornam, pela propaganda dos empreendimentos, bens privados. Alguns empreendimentos usam proximidade com o Parque do Ibirapuera como forma de torná-lo o jardim do edifício. O mesmo ocorre com o Parque Burle Marx e com o Parque Villa Lobos. 


\section{LOCALIZAÇĀO DOS EMPREENDIMENTOS IMOBILIÁRIOS EM SÃO PAULO}

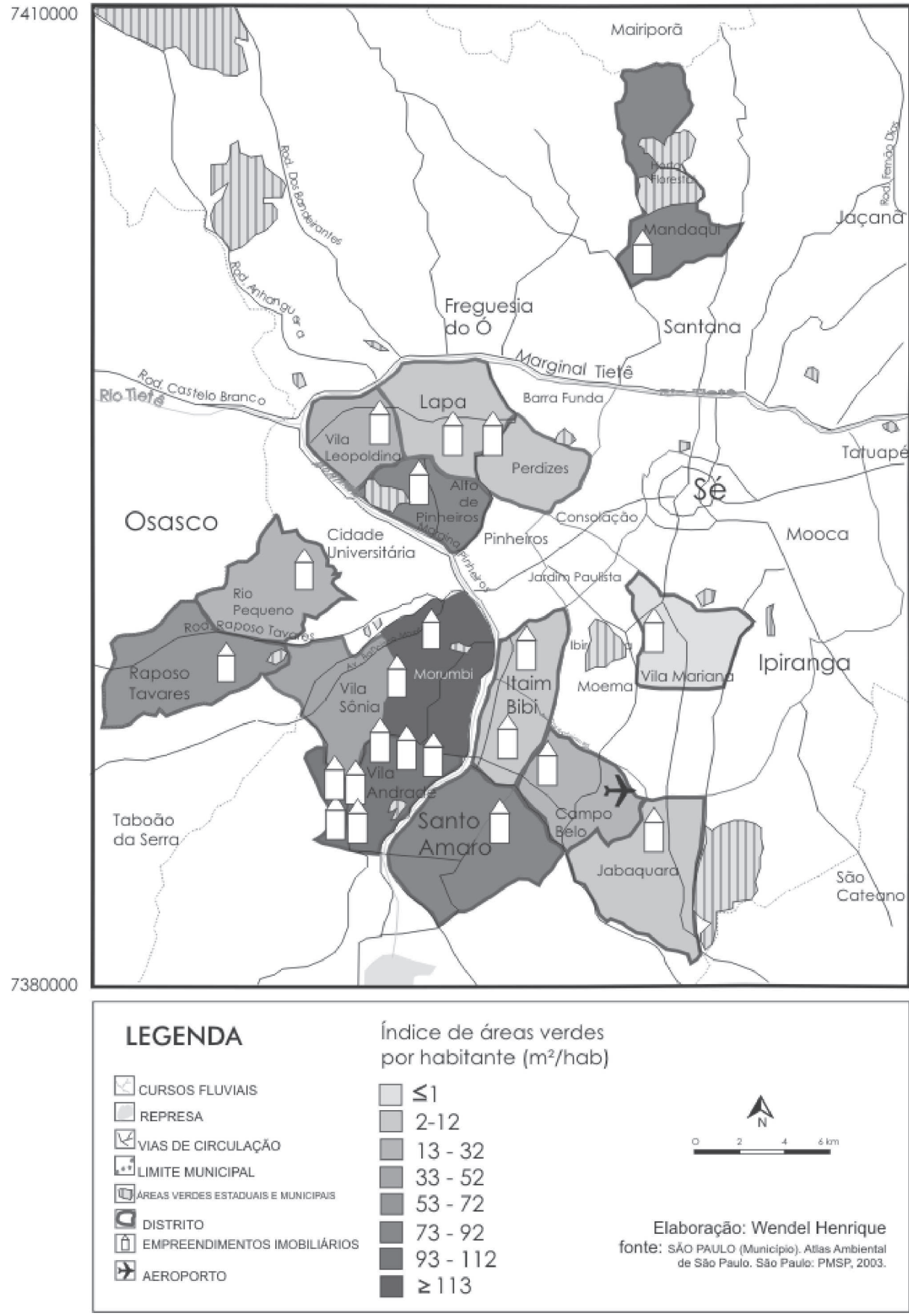


Além da ideia de apropriação dos parques públicos, muitos empreendimentos em São Paulo fazem uso de uma ideia de proximidade com estes parques, uma vez que, se tratam de empreendimentos localizados em já densas áreas residenciais. Os croquis de localização seguem uma tendência geral de aproximar, às custas do sacrifício da escala na representação cartográfica, as áreas verdes dos empreendimentos.

Estes croquis, como representação da ideia de natureza que se vende, fazem uso maciço da cor verde na sua impressão e tendem a aumentar exageradamente a quantidade de áreas verdes no entorno do empreendimento. Se um estrangeiro que chegasse a São Paulo, vendado, fosse pautar suas impressões apenas pelas árvores e áreas verdes destes croquis, com certeza irá reforçar a ideia de que o Brasil é um país ocupado inteiramente pelas florestas.

As maquetes, animações e vídeos (graças ao computador) dos empreendimentos também fazem uso recorrente das substituições das áreas construídas pelas áreas verdes. Um prédio localizado na Vila Buarque (na região da Praça da República) parece no panfleto como se estivesse inserido no interior da Serra da Cantareira. Visitando o local percebe-se a inexistência de qualquer forma arbórea ou arbustiva (o índice de área verde na região da República - com exceção das praças - é praticamente zero).

Outra estratégia de marketing é a alteração do bairro onde se localizam os empreendimentos. Como exemplo, a venda que um condomínio no Morumbi, mas que realmente se localiza na Vila Sônia. Enquanto o Morumbi tem um índice de área verde por habitante, segundo o Atlas Ambiental de São Paulo (2003), de 239,04 m²/ hab., a Vila Sônia só tem 35,06 $\mathrm{m}^{2} /$ hab.

Outros exemplos desta associação de empreendimentos com a natureza em bairros onde a natureza é praticamente nula ou ínfima estão localizados nos distritos de: Perdizes (a área verde por habitante, segundo dados do Atlas Ambiental de São Paulo, de 2003, é de 5,94 m²/hab) e Jabaquara (4,02 $\left.\mathrm{m}^{2} / \mathrm{hab}\right)$.

Entretanto, o caso mais impressionante da anulação da cidade e supervalorização do verde ocorre na Vila Andrade. Além do predomínio do tom verde nas figuras de propaganda do empreendimento, os edifícios são, através de técnicas computacionais, inseridos no meio de uma grande floresta tropical, repleta de árvores de grande porte, e não no espaço urbano de São Paulo, nas proximidades da Marginal Pinheiros, na vertente oposta aos grandes prédios inteligentes da região da Avenida Berrini. As ilustrações da sala do apartamento mostram que a vista de uma das janelas seria de apenas uma imensa floresta, o que não lembra em nada a vista real do local. 
Os agentes do mercado imobiliário que constroem e vendem estes empreendimentos fazem, no seu processo de superexploração do valor de troca de seu condomínio, um espaço social, econômica e geograficamente segregado do restante da cidade, através da supressão da própria cidade. Mesmo que esta análise seja marcada apenas pela observação dos materiais de propaganda, as ideias começam a se materializar no espaço. No ato de negar a cidade, por eliminação da paisagem urbana na imagem, o condomínio nega também a possibilidade de construção coletiva de uma natureza urbana, pois excluído, mesmo que ideologicamente, de São Paulo e inserido no meio da tranquilidade da floresta, o empreendimento evidencia e aquilata a satisfação individual dos seus moradores/consumidores em possuir um bem/mercadoria tão exclusivo - a natureza.

Pela análise dos dados do Atlas Ambiental de São Paulo (2003), percebe-se que a região da Vila Andrade possui uma das mais altas taxas de área verde por habitante da cidade. Entretanto, a aceleração do processo de construção de condomínios de alto padrão na região - em função desta natureza urbana ainda presente (e representada em grande parte por eucaliptos recentemente plantados, mostrando, mais uma vez, que a natureza na cidade é obra socialmente construída) - tende a diminuir este índice, quer seja pelo processo de substituição das áreas verdes pelas áreas construídas, quer pelo simples aumento da densidade populacional. Assim, a Vila Andrade terá uma menor quantidade de área verde a ser dividida por um maior número de moradores.

Ao lado da propaganda, contendo a proximidade do "verde", destaca-se sempre a presença de shopping centers nas redondezas. Afinal, apesar da ideia romântica da proximidade do verde, a sociedade moderna, ou melhor, as classes média e alta, não admitem a possibilidade de retorno ao estado primitivo da cidade ainda no meio da natureza. Ter árvores no entorno é importante, mas as infra-estruturas básicas (água, luz, esgoto, telefone, antena de celular, TV a cabo, fibra ótica, hipermercado, delicatessen, pet shop, locadora de DVD, academia de ginástica, enfim, uma gama de serviços essenciais, 24 horas por dia) não podem estar longe do residencial (condomínio) natural.

Observa-se, através dos empreendimentos imobiliários na atualidade, o triunfo da apresentação sobre a significação. O engano se apresenta como verdadeiro. A criação de fantasias de natureza, faz com que os condomínios, as reservas, os parques naturais e os aquários, espaços altamente tecnificados, sejam apresentados como naturais. A natureza passa a ser associada a equipamentos e objetos cada vez mais técnicos.

Para tornar a situação da apropriação da natureza na cidade pelos empreendimentos imobiliários ainda mais interessante, um novo padrão global de natureza 
é inserido. A maior parte dos lançamentos imobiliários - prédios e condomínios - é nomeado, como pode ser constatado nos empreendimentos já nominalmente citados, em línguas estrangeiras, especialmente inglês, francês e italiano.

Num levantamento realizado em março de 2003 através de um sítio especializado na comercialização de empreendimentos imobiliários pela Internet (www.planetaimovel.com.br), foram encontrados 32 lançamentos de alto padrão em São Paulo, os quais 26 batizados em línguas estrangeiras. Numa outra consulta aos vários sítios da Internet, em 2004, mais de 90\% dos empreendimentos que estavam sendo anunciados naquele momento foram nomeados com termos estrangeiros.

Além da questão linguística, o mais importante é que estes empreendimentos, que fazem uso de uma ideia de natureza como uma forma de aumento de seus preços, na maioria dos casos observados, introduzem uma ideia "globalizada" de natureza, através, por exemplo, de esquilos e elementos da flora de outros climas. Esta natureza externa, padronizada, bane aquilo que se poderia considerar como uma ideia de natureza brasileira. Dos 32 lançamentos de alto padrão pesquisados em março de 2003, 12 estão ligados a alguma ideia de natureza. Assustadoramente, onze destes empreendimentos remetem a uma ideia exterior ou globalizada de natureza e apenas um a uma natureza tipicamente brasileira.

Estas novas ideias e conceitos de natureza carregam muito das intencionalidades capitalistas e pouco de valores culturais identitários, mostrando uma transformação (outra cultura ou a própria cultura local mudando?), banindo objetos ou formas que tinham fortes laços com o lugar e inserindo outros que são estranhos. Na cidade de São Paulo, o encontro destas duas forças, mostra uma tendência ao domínio de uma ideia de natureza padronizada, asséptica e esteticamente definida por modelos que não condizem com a realidade brasileira. Uma natureza globalizada, que remete a um mundo mais civilizado, refinado, elegante e sofisticado, uma cultura mais distante da natureza primitiva, muito diferente da nossa cultura tropical, quente e úmida, visualmente confusa e muito próxima da natureza.

Assim, a racionalidade instrumental capitalista cria e insere alguns objetos como os esquilos, o urso panda e o plátano, os quais são simbólica, estrutural e funcionalmente mais avançados e mais perfeitos que a natureza, neste caso, que a natureza tropical pode criar. "Na realidade, quanto mais distante os objetos são da natureza, mais perfeitos eles são". ${ }^{146}$

Alguns empreendimentos também estão atrelados à ideia de uma natureza campestre ou rural. O projeto parece resgatar a tranquilidade como uma virtude da natureza urbana, trazendo o sossego de cidades do interior. Na Vila Olímpia, alguns 
empreendimentos buscam criar a ideia de uma chácara urbana, com ar puro e como um local de repouso e de vida familiar. Uma fuga da vida agitada e estressante da grande cidade. O edifício estaria envolto em um "imenso" pomar.

Contraditoriamente, o mesmo marketing que vende a tranquilidade e o ar puro de empreendimentos repletos de verde, como bosques, praças e jardins valoriza a vida noturna agitada, cheia de cafés, peças de teatros, musicais e infra-estrutura com grandes vias de circulação. A tranquilidade da Vila Olímpia cedeu espaço para os edifícios inteligentes que apagam os traços culturais e sociais do passado mítico valorizado primeiramente pelas propagandas. Toda a infra-estrutura modernizante da Vila Olímpia acabou por tornar o lugar o antônimo do sossego, inclusive com o adensamento do tráfego aéreo em Congonhas, com aviões decolando ou se aproximando da pista do aeroporto sobre o bairro.

Todas as idealizações da natureza, pelos habitantes da cidade, mostram uma dupla determinação, sendo ambas relacionadas à distância que a natureza (objeto a ser idealizado) está da vida cotidiana. De um lado, aqueles que estão mais próximos da natureza, que buscam a superação das dificuldades impostas por ela e, de outro, aqueles que habitam lugares altamente tecnificados, longe da natureza e das suas limitações, mas que alimentam o sonho e o desejo de proximidade com a natureza. Como coloca Greenbie (1988), o executivo de uma grande corporação que trabalhe no $40^{\circ}$ andar de uma torre de escritórios, a paisagem urbana pode não ser agressivamente ameaçadora, mas agressivamente excitante, um símbolo da vontade e do poder humano. Ele pode apreciar a presença de árvores na rua, mas esta apreciação pode não ser uma prioridade para ele, especialmente se ele mora numa boa casa num subúrbio verde. Para o balconista de uma das lojas do térreo, uma caminhada num parque no caminho para casa pode ser uma forma de recuperação de suas força; mas ele também pode preferir um caminho mais curto para seu apartamento com uma televisão e algumas plantas num vaso na janela, ou parar na paisagem genuinamente social de um bar. ${ }^{147}$

Aliando-se à ideia da natureza como um elemento de consumo exclusivo para as classes altas da cidade de São Paulo, criam-se verdadeiros espaços de segregação no interior do tecido urbano paulistano.

Dos empreendimentos analisados, apenas uma parcela pequena, da grande oferta encontrada diariamente nos jornais, reforça a questão da mudança de perspectiva na relação do homem com a natureza, passando, como já foi observado nos capítulos anteriores, de uma ação na natureza visando os aspectos de vida coletivos da sobrevivência do grupo para um padrão individualista, segregatório e egoísta de consumo da natureza, enclausurada nestes condomínios e de usufruto apenas de seus moradores, ou melhor, consumidores. 
A natureza na cidade não é um bem coletivo, não é um objeto socialmente compartilhado, é uma mercadoria exclusiva que "o dinheiro" pode comprar.

\section{A FELICIDADE NÃO TEM PREÇO, TEM ENDEREÇO - FLORIANÓPOLIS/SC}

A cidade de Florianópolis, ou melhor, a área insular do município ${ }^{148}$, vem sendo apontada nos últimos anos como um oásis de qualidade de vida urbana no Brasil. Uma campanha maciça na mídia vende as benesses da vida na Ilha de Santa Catarina. A natureza, a infra-estrutura, a educação, a sofisticação e a segurança são os aspectos vendidos pelo marketing de Florianópolis, capitaneado pelas grandes empresas do mercado imobiliário e pelo poder público, estadual e municipal.

Toda esta campanha, que se intensificou a partir do final dos anos 90, resultou numa explosão da especulação imobiliária na Ilha, com a atração de pessoas, principalmente paulistas, gaúchos e fluminenses, de alto poder aquisitivo ${ }^{149}$. Estima-se que a participação na população das classes mais altas cresceu 10\% nos últimos 10 anos em função desta migração para a cidade. Este crescimento da procura por moradias levou a um grande aumento dos preços dos imóveis na Ilha, tanto para a sua aquisição quanto para os aluguéis. Muitos empreendimentos e loteamentos foram construídos, associando qualidade de vida com natureza para cooptar os investimentos dos "futuros moradores" desta "Ilha da Magia", repetindo as mesmas estratégias de markting observadas em São Paulo.

Um bom exemplo da relação do mercado imobiliário com a natureza em Florianópolis é a área de Jurerê (norte da Ilha de Santa Catarina) dividida em: Jurerê Tradicional e Jurerê Internacional. O senso comum dos moradores de Florianópolis e os valores do IPTU indicam entre estas duas localidades uma grande diferenciação econômica, com a associação entre a maior renda - Jurerê Internacional - e a simplicidade - Jurerê Tradicional.

Jurerê Internacional está voltado para o estabelecimento de moradias permanentes e não apenas para atender às demandas turísticas no verão. Estas moradias são destinadas para uma população de altíssimo poder aquisitivo, originada de outros estados (segundo uma corretora de imóveis 30\% dos compradores dos imóveis são gaúchos, outros 30\% paulistas, e apenas 15\% catarinenses), uma vez que as construções devem ter no mínimo $400 \mathrm{~m}^{2}$ e seguem um padrão arquitetônico, obrigatoriamente predefinido, no intuito de criação de uma identidade urbanística, no 


\section{LOCALIZAÇĀO DOS EMPREENDIMENTOS IMOBILIÁRIOS EM FLORIANÓPOLIS}

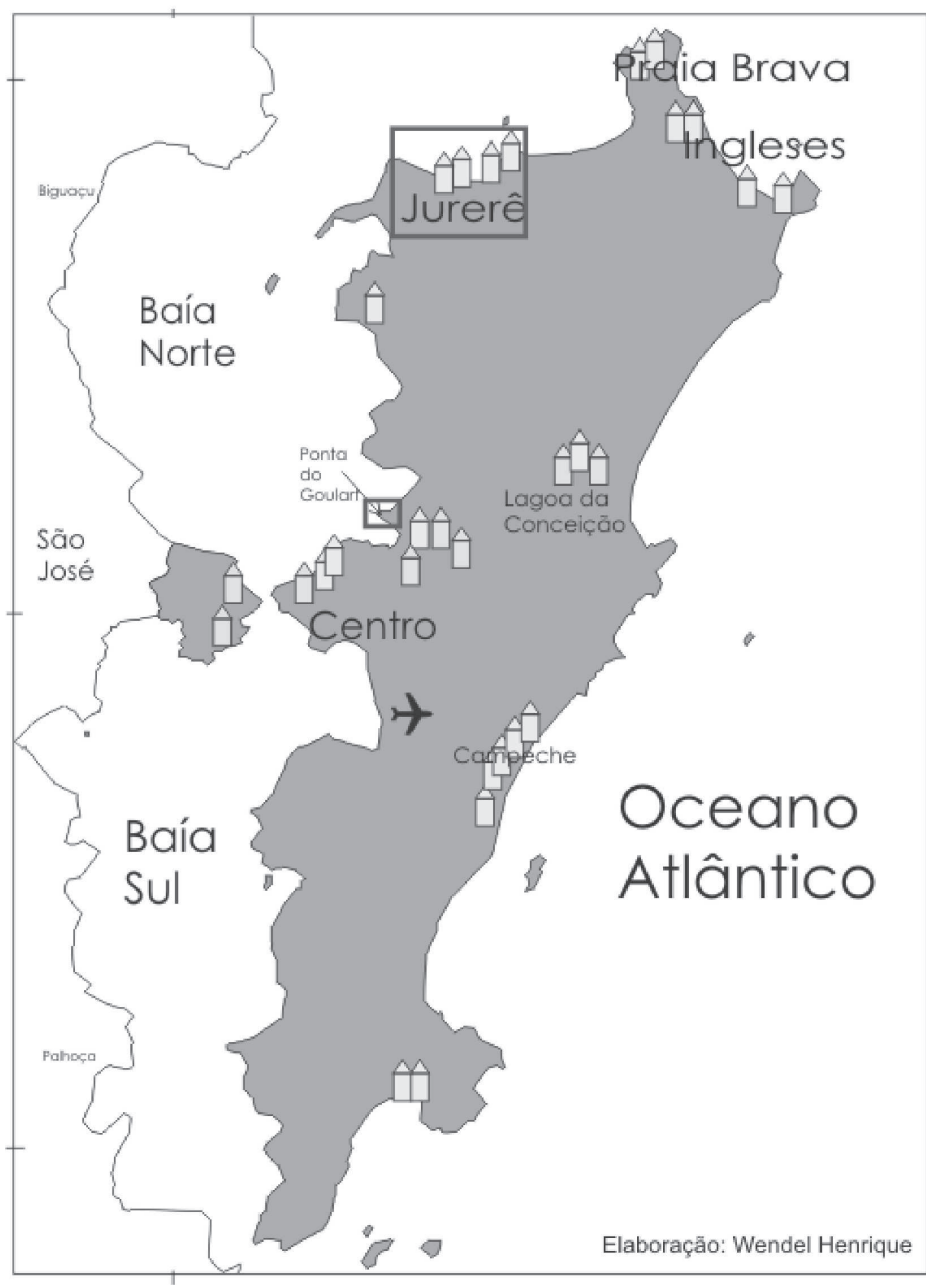

\section{LEGENDA}

LINHA DE COSTA

$\checkmark$ LIMITE MUNICIPAL FLORIANÓPOLIS

(1) EMPREENDIMENTOS IMOBILIÁRIOS

$\boldsymbol{F}$ AEROPORTO

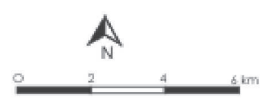


caso, um estilo "Califórnia". Estas construções não devem possuir muros, criando uma atmosfera de segurança e proximidade, típica da imagem do subúrbio americano. Mesmo assim, observam-se em praticamente todas as casas placas, indicando a opção dos moradores por serviços de segurança privada, além de contar com a segurança própria do loteamento, que no início de sua ocupação era realizada por seguranças em bicicletas (ecologicamente correto). Entretanto, em algumas construções também podem ser vistas obras de aumento dos muros laterais e a construção de cercas, pois se tem constado um aumento dos roubos e furtos na área. Grande parte dos moradores de Jurerê Internacional divide a sua residência entre Florianópolis e outras cidades, notadamente São Paulo ${ }^{150}$.

Com referência ao plano urbano do loteamento, ele se aproxima da configuração de um "bairro-jardim", com blocos retangulares, lotes amplos e grandes áreas verdes nos intervalos das construções, principalmente, entre os blocos de apartamentos (com média de 4 pavimentos). O traçado urbano ${ }^{151}$ está assentado sobre um sítio plano - um terraço marinho - o que traz grandes problemas de drenagem nos períodos chuvosos e um grande refluxo de esgotos. Ainda assim, a área de Jurerê é uma das únicas de Florianópolis a contar com sistema de coleta e tratamento de esgoto, sendo, juntamente com o tratamento de água, um serviço que não é prestado pelos órgãos públicos.

Observando uma fotografia aérea, nota-se que os primeiros blocos imediatamente posteriores à praia são maiores que o restante do tecido urbano, com uma menor densidade de construções, configurando-se nas áreas mais valorizadas do loteamento, com construções de altíssimo padrão e preços elevados (em média, cinco milhões de reais, segundo informações de uma corretora de imóveis). Na área central de Jurerê, encontra-se o centro comercial do loteamento - o "Open Shopping" - e uma área residencial verticalizada. É interessante notar o uso da natureza como uma barreira entre esta zona mista (comercial e residencial) e uma zona exclusivamente residencial horizontal. Entre estas duas zonas observa-se um parque verde linear, margeando um canal aberto para drenagem do terraço marinho, servindo como uma "barreira verde" entre uma área mais popular e movimentada e uma outra mais elitista e "tranquila".

Outro ponto forte vendido no mercado imobiliário de Florianópolis está relacionado a vista (do mar, das lagoas ou das áreas verdes). Desta forma, há uma grande valorização das sacadas dos empreendimentos. Um diferencial da infraestrutura dos empreendimentos com padrão mais elevado, principalmente edifícios residenciais, é a presença de churrasqueiras nas sacadas. Entretanto, apesar da vista, por exemplo, dos prédios localizados na Avenida Beira Mar Norte, ser espetacular, os outros sentidos parecem não merecer a atenção devida, como o olfato, por conta do mau cheiro dos esgotos sem tratamento lançados na Baía Norte 
e a audição, pelo barulho incessante dos carros e ônibus que circulam pela avenida, a mais movimentada da cidade.

Os agentes do mercado imobiliário retomam a romantização da natureza e a valorização do mito da natureza paradisíaca e intocada, negando toda a construção social da natureza ao longo da história humana. Confirma-se uma ideia de Santos (1999, p. 53),

no princípio, tudo eram coisas, enquanto hoje tudo tende a ser objeto, já que a partir de um conjunto de intenções sociais, passam, também, a ser objetos. Assim a natureza se transforma em um verdadeiro sistema de objetos e não mais de coisas e, ironicamente, é o próprio movimento ecológico que completa o processo de desnaturalização da natureza, dando a esta última um valor.

Em Florianópolis, diferentemente do que foi constatado em São Paulo, a presença material/física da natureza - água e vegetação - se faz mais presente. Mesmo assim, na região central, a presença de áreas verdes fica restrita às praças e aos jardins, o que não impede que alguns empreendimentos utilizem a natureza apenas como ideia/símbolo, neste caso, muito próximo aos casos analisados na cidade paulista.

Os agentes do mercado imobiliário ainda buscam impor um crescimento acelerado da população da ilha, a qual se configuraria num grande resort urbano para população de alta renda. Os pobres seriam "expulsos" para o continente. A ideia do crescimento urbano, associada com valorização da natureza e da qualidade de vida, não está atrelada, infelizmente, às fortes tradições culturais dos moradores da ilha - pescadores e brasileiros de origem açoriana (os manezinhos). A especulação imobiliária, além de se apropriar de natureza ainda presente em certos recantos da ilha, está destruindo a cultura local, vista como algo ultrapassado e fora de moda. A modernidade urbana cosmopolita é o desejo dos empreendedores do mercado imobiliário de Florianópolis. Este processo se dá da mesma forma que o estabelecimento de um padrão internacional de natureza para as cidades, como foi observado em São Paulo.

Entretanto, alguns indicativos presentes mostram que o crescimento urbano de Florianópolis chegou ao seu limite, em função:

- da falta de infra-estrutura básica (água, energia elétrica, vias de circulação); 
- da falta de opções culturais, e o lazer se restringindo às praias no verão;

- do super aquecimento do mercado imobiliário e da elevação absurda dos preços dos imóveis, empurrando a classe média e os pobres para os municípios do continente - São José, Palhoça etc.

- da falta de espaço para o crescimento urbano, pela presença de áreas de proteção ambiental (APP). Assim, a área urbana só poderá aumentar horizonte através da construção de aterros na linha costa ou da ocupação irregular das APPs.

\section{VIVER COM ESTILO NO JARDIM TROPICAL - SALVADOR/BA}

Na cidade de Salvador/BA (Avenida Paralela, Horto Florestal, Iguatemi, Rio Vermelho, Corredor da Vitória, Itaigara, Cabula e Orla Atlântica), na Região Metropolitana de Salvador ou no Litoral Norte/Orla Atlântica de Lauro de Freitas, Camaçari e Mata de São João, áreas já ocupadas ou altamente transformadas são apropriadas pelos agentes do mercado imobiliário, muitos com capital estrangeiro, produzindo loteamentos e condomínios (vários, na verdade, apenas loteamentos, mas que são vendidos como condomínios, sem ter a regulamentação específica a esta figura urbanística). Estes empreendimentos são associados a uma ideia de natureza primitiva, a qual se torna sinônimo de qualidade de vida e transforma-se em valor econômico, aumentando os preços dos apartamentos, casas e edifícios.

No caso de Salvador, a vista (para o mar), a localização Av. Paralela (certa distância dos bairros mais populares e a proximidade da praia - não em frente) e a infra-estrutura (patrocinada pelo Estado) atraem os investimentos do mercado imobiliário, criando na cidade, espaços "luminosos" do ponto de vista técnico-científico-informacional.

Na Avenida Paralela encontram-se vários empreendimentos imobiliários, o maior deles com 18 torres de apartamentos em uma área de $100 \mathrm{mil} \mathrm{m}^{2}$, que alia a ideia da natureza, que está presente até no nome em francês do empreendimento, com as inúmeras possibilidades de lazer que serão oferecidas, fazendo com que o morador desfrute de todas as atividades de um resort sem sair de casa. Estimativas indicam que o número de moradores neste empreendimento ultrapasse 5 mil. Considerando a área toral do terreno, os espaços que cada morador terá "direito", bem como "a sua" parcela de natureza não serão tão extensos. Além deste empreendimento, outros associam a ideia do condomínio com um bairro, vendendo inclusive a ideia do "bairro [condomínio] que já nasce nobre". 

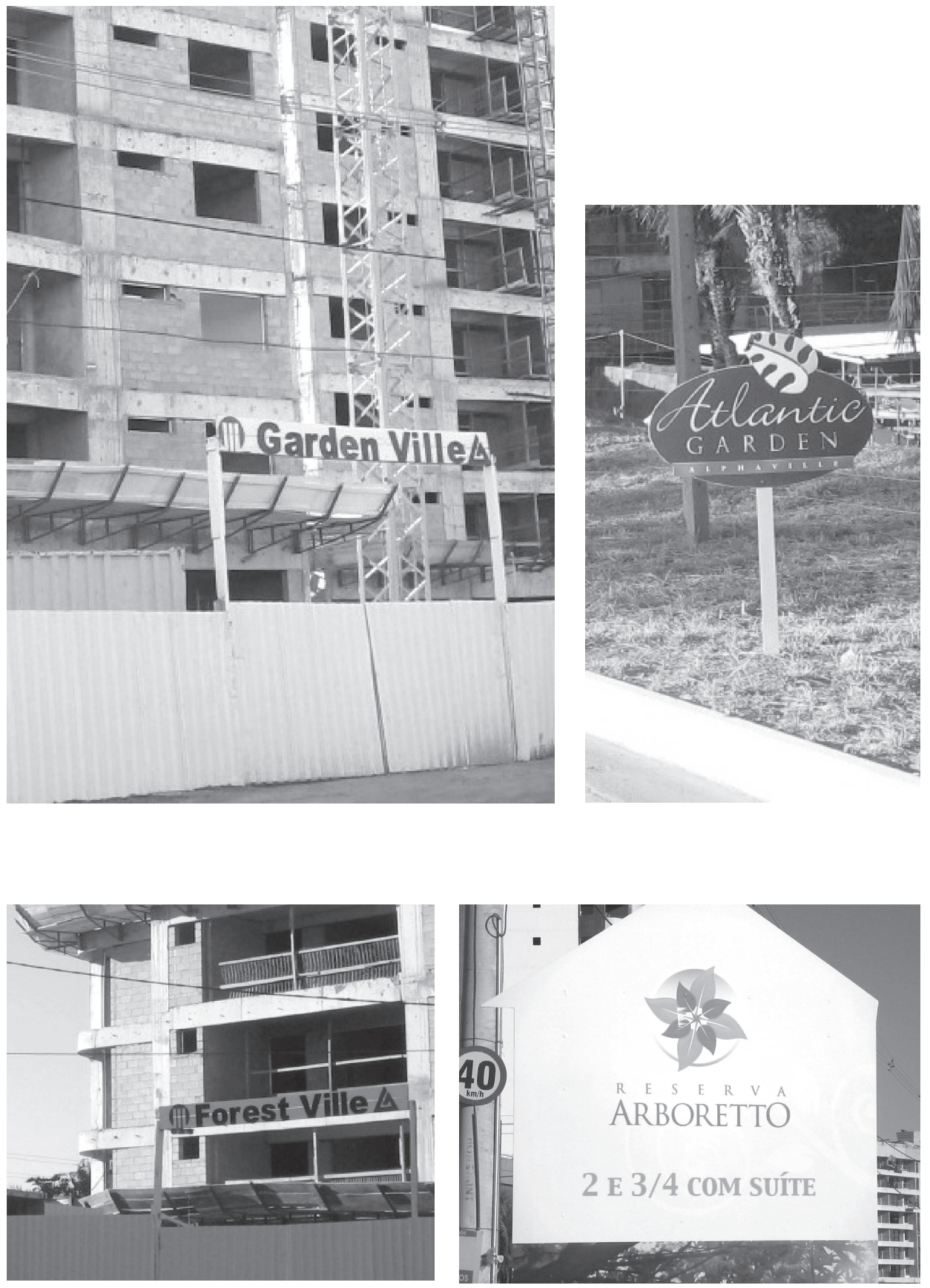

Propagandas em vias públicas e empreendimentos que fazem referências à natureza. 


\section{LOCALIZAÇÃO DOS EMPREENDIMENTOS IMOBILIÁRIOS EM SALVADOR}
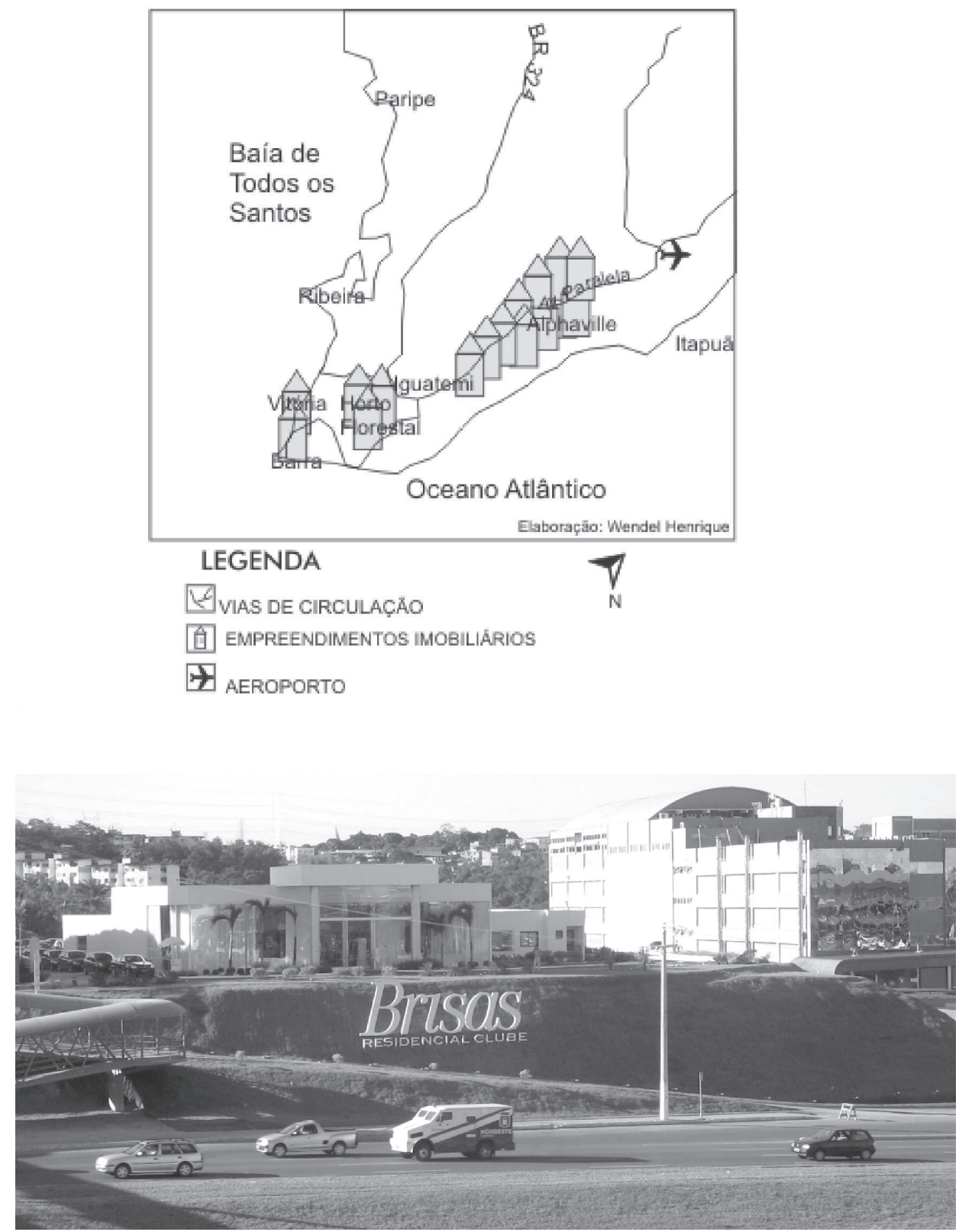

Obras de vários empreendimentos na região do Alphaville / Salvador 

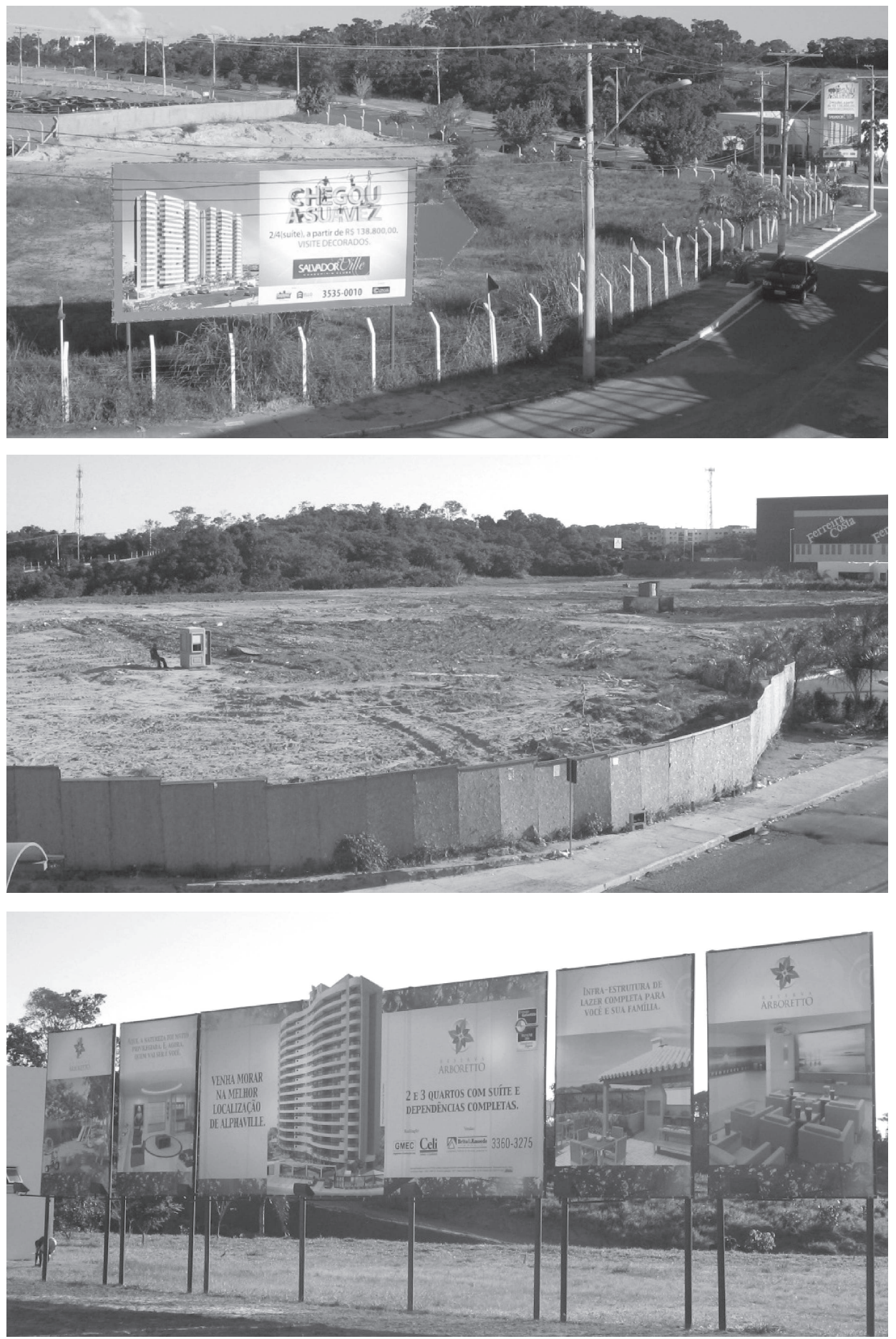

Obras de vários empreendimentos na região do Alphaville / Salvador 
Estes empreendimentos negam na cidade o local privilegiado para a vida e para o cotidiano urbano, que é sem dúvida o bairro, com suas ruas e praças apropriadas, comércios conhecidos e utilizados rotineiramente e, principalmente, pelo encontro com os demais moradores, com suas vidas públicas e privadas se misturando na formação de uma identidade do bairro e em um sentimento de pertencimento. $O$ bairro é também o lugar da diversidade, uma vez que os moradores possuem certa heterogeneidade socioeconômica, o bairro é um espaço aberto cheio de vida.

Nestes condomínios e no seu entorno, a população passa a ser praticamente homogênea, nos aspectos econômicos, culturais, sociais, políticos etc. O condomínio acaba por criar uma territorialidade ocupada, momentaneamente, por um grupo específico ou por uma "tribo urbana" que se diferencia pelas suas formas de viver e de vestir-se. Esta é uma das tendências da grande cidade hoje, a substituição dos bairros, nos quais as diversas famílias conviviam por longos períodos de tempo, pelas territorialidades urbanas. Espaços específicos, ocupados por um determinado grupo (ou tribo), definidos basicamente por características estéticas, econômicas e de gênero. Territorialidades urbanas de grupos de ecologistas, de punks, de roqueiros, de gays, de feministas, de solteiros, de grupos de esquerda, de direita, de artistas, de empresários, de mauricinhos e patricinhas, de surfistas etc.

Na supervalorização da natureza e de determinados setores e bairros da cidade, instaura-se, em alguns casos, um processo de requalificação e gentrificação do espaço urbano, onde todos os prazeres nos nichos específicos do mercado imobiliário se dão na órbita da acumulação, dentro de uma racionalidade capitalista. Na comercialização da estética ou do natural, os objetos e as ideias tornam-se atividades financeiras, industriais e de consumo, tentando impregnar os empreendimentos imobiliários de um valor exclusivo.

Estes nichos de mercado são explorados a partir da mobilização dos desejos humanos e na sua pseudoexclusividade, negando seu acesso a todas as pessoas. Do ponto de vista geográfico, definem-se territórios excludentes. Como, por exemplo, um "condomínio" destinado ao público gay em Arembepe (Camaçari), cuja publicidade evoca um condomínio de praia que oferece um diferencial que você não encontra em nenhum outro: a liberdade de viver a vida da maneira que você gosta, em uma paradisíaca praia com piscinas naturais formadas pelos recifes. Associada as maravilhosas belezas naturais, o condomínio conta também com uma infra-estrutura completa e está inserido em uma área que abriga o Projeto Tamar, "morada das tartarugas marinhas". Todo o material de divulgação impresso em rosa, com flores, um corpo de homem com uma tatuagem de outro homem e a frase "meu amor" e outro com um corpo de mulher e a tatuagem de outra mulher e a mesma frase. 
Para atender a "consciência ecológica" e demonstrar o respeito com a natureza, muitos empreendimentos em Salvador têm desenvolvido "ações de sustentabilidade": com coleta seletiva de lixo, reutilização de água da chuva, horta, pomar, jardim com flores o ano inteiro, áreas com iluminação natural, "resgate" de espécies nativas nos viveiros dentro dos empreendimentos.

Na Região Metropolitana de Salvador também são inúmeros os exemplos. Na praia de Guarajuba "desfrutar de conforto, lazer e segurança no melhor do Litoral Norte da Bahia", é "um privilegio que faz parte da sua natureza", "você e sua família, desfrutando de uma praia paradisíaca e o melhor da natureza". Este empreendimento, localizado em uma APA, afirma desenvolver um Projeto de Educação Ambiental "para colaboradores e comunidades vizinhas", ou seja, os moradores/ proprietários, não precisam receber aulas de educação ambiental, uma vez que só por terem escolhido morar no empreendimento já tem "consciência ambiental", já os moradores do entorno e os trabalhadores precisam. No caso de uma comunidade vizinha ser de um grupo indígena, eles também irão ter aulas de educação ambiental? Desenvolver ações de "responsabilidade ambiental" permite aos agentes do mercado imobiliário ignorar ou contornar a legislação e com o auxílio dos próprios órgãos e esferas públicas construir um condomínio em uma área de lagoas e dunas, dentro de uma Área de Proteção Ambiental?

Praticamente todo o Litoral Norte da Bahia, de Salvador até o complexo Costa do Sauípe está tomada por empreendimentos imobiliários que fazem uso da natureza na sua valorização, mas que estão sendo construídos em áreas frágeis do ponto de vista natural, derrubando as áreas verdes, drenando e aterrando lagoas. Estes empreendimentos são em sua maioria construídos por agentes de capital internacional e adquiridos por estrangeiros, portugueses e espanhóis em sua maior parte. Em janeiro de 2007, em uma viagem de Salvador a Lisboa, a revista de bordo da empresa aérea divulgava uma grande feira de imóveis localizados na Bahia a ser realizada em Lisboa, com a frase "agora você não precisa conquistar, pode comprar".

Assim, nas áreas costeiras o foco prioritário de venda das unidades está no mercado internacional, articulando uma relação direta entre o mundo e o lugar. Os condomínios litorâneos acabam por combinar duas ordens, uma distante, relacionada aos espaços luminosos conectados ao mundo urbano próspero, globalizado e desenvolvido, e outra próxima (local, tradicional e ainda ligada a uma ruralidade) e que entra em choque. A ordem distante pode atuar hegemonicamente, ocupando áreas e expulsando comunidades locais para sítios de risco social e natural, configurando espaços opacos. A inclusão do espaço litorâneo nordestino na produção e consumo imobiliário internacional tem provocado a expulsão e a exclusão das comunidades locais das benesses do desenvolvimento socioespacial. 
No Litoral Norte da Bahia, as contradições e os conflitos na produção do espaço decorrentes da inserção de condomínios fechados em áreas ambientalmente frágeis e socialmente vulneráveis são claras. Esta faixa é protegida ambientalmente e ocupada por comunidades tradicionais, mas tem sido disputada por inúmeras empresas imobiliárias nacionais e internacionais para a construção de condomínios de grande porte. Entre os novos condomínios um deles, localizado no município de Mata de São João, chama a atenção. O condomínio foi entregue no final de 2008 e conta com 163 casas, infraestrutura básica e de lazer (quadras, piscinas, piers).

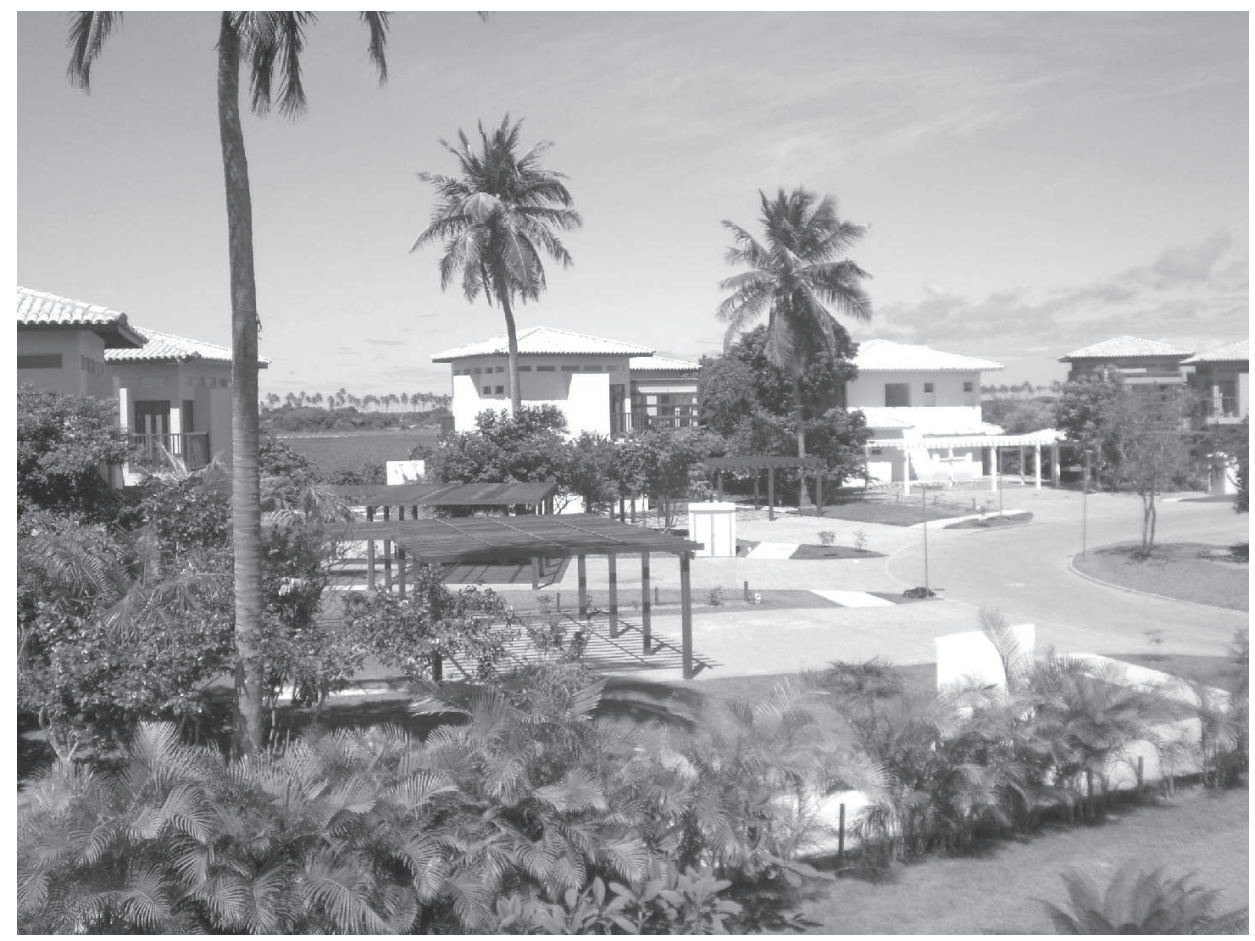

Aspecto geral do Condomínio, em Sauípe, no entorno de uma laguna. Ao fundo, ao longo da faixa de coqueiros está a praia.

As lagunas que nomeiam o empreendimento foram perenizadas através da construção de aterros e barragens, isolando-as do oceano, alterando todo o ecossistema. O entulho resultante da construção foi depositado em uma área de restinga e de manguezal. Todo o condomínio, com forte apelo a cultura tropical e mediterrânea (?), foi construído para atender aos anseios de moradores/usuários estrangeiros, notadamente portugueses. 

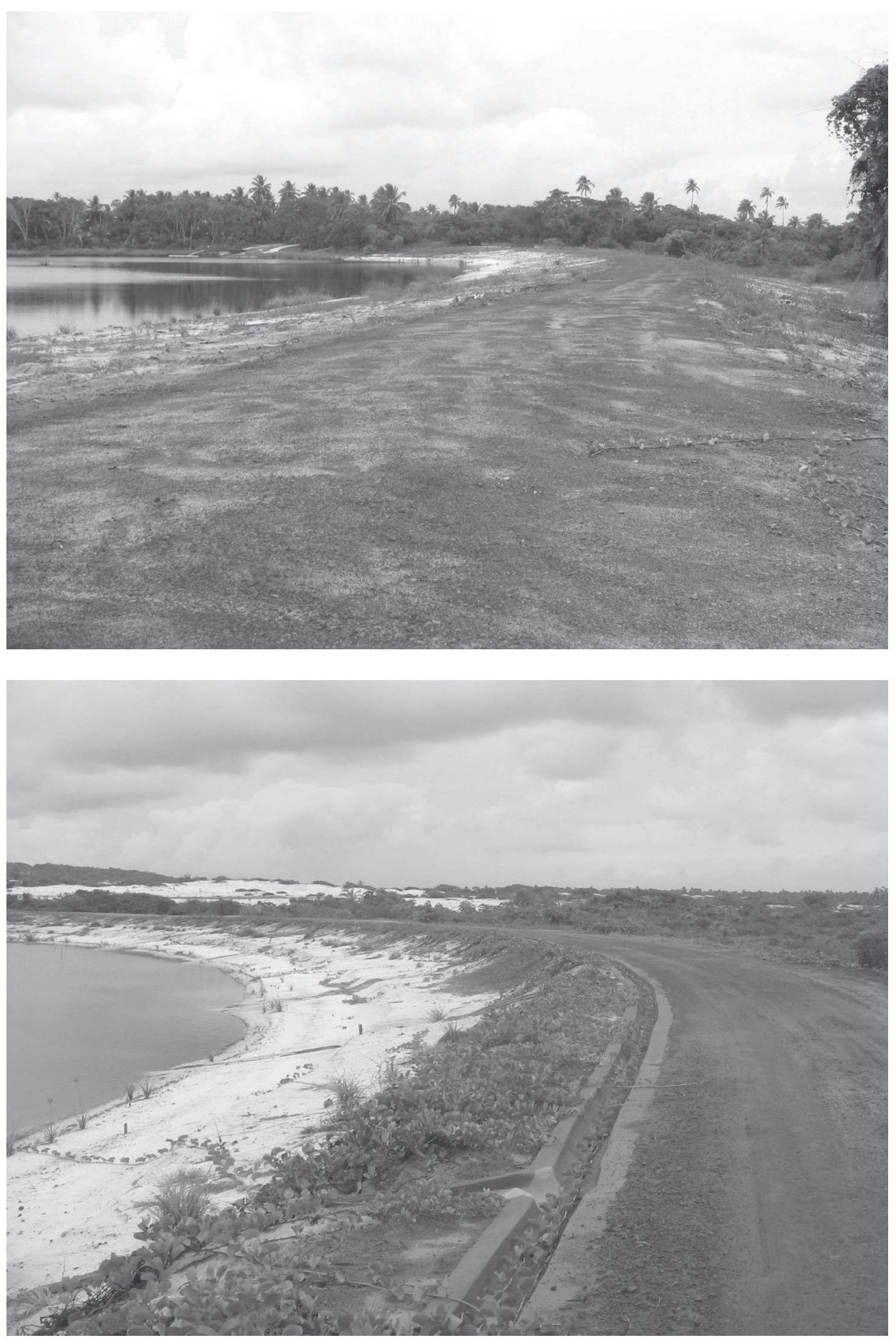

Barragens construídas para perenização da laguna 


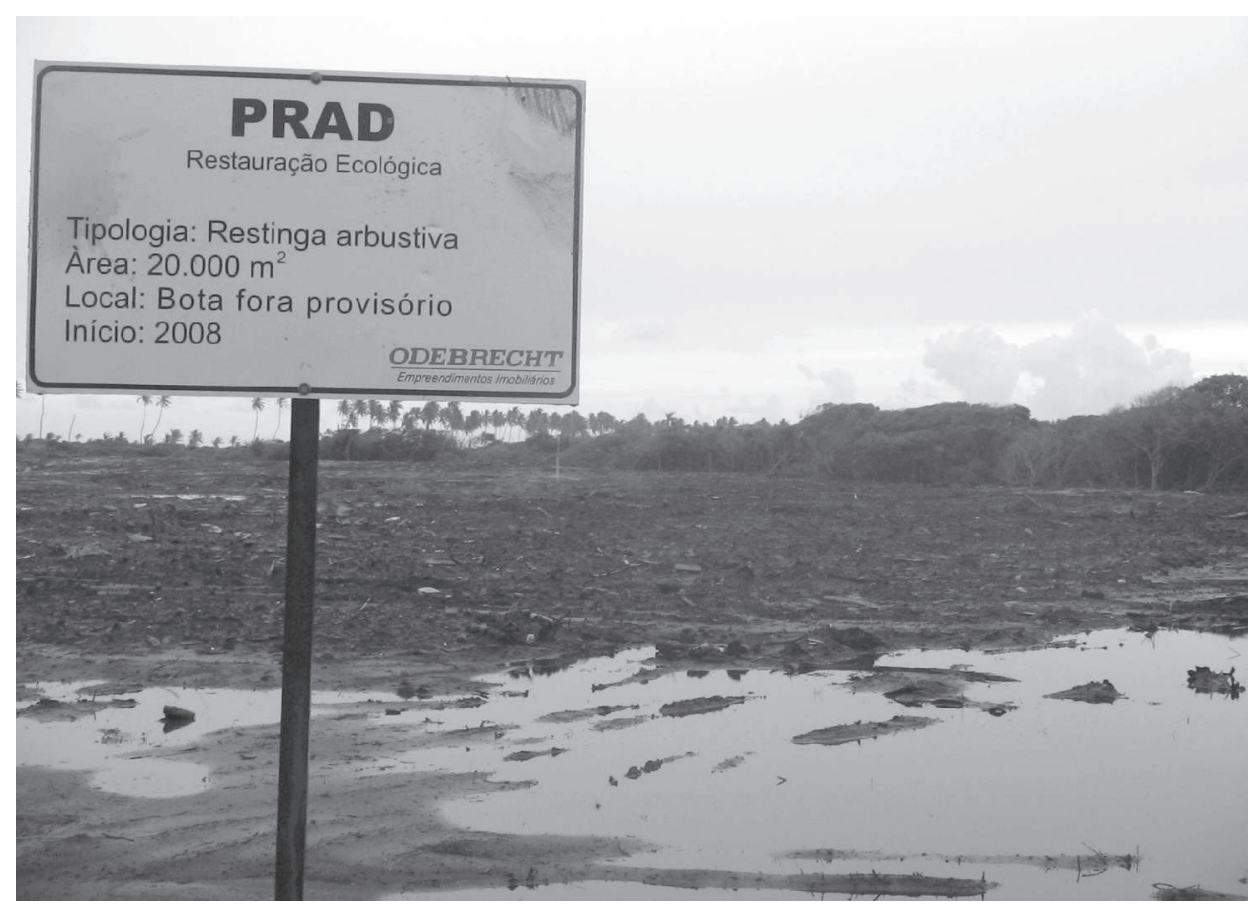

Área de "bota fora provisório" para as obras do condomínio. A licença de implantação foi dada pelo CRA (Órgão ambiental do Governo do Estado da Bahia), em 2005. A recuperação deveria ser iniciada em 2008, mas a foto, obtida em março de 2009, mostra que a recuperação ainda não começou.

A propaganda foi realizada em exclusivas revistas internacionais valorizando as casas, algumas com valores superiores a $\mathrm{R} \$ 1$ milhão. Ao redor de $20 \%$ das unidades estão ocupadas, a maioria apenas por algumas semanas no ano, pois os proprietários circulam por diversas casas ao longo do ano, vivendo exclusivamente o verão ao redor do mundo, conforme entrevistas realizadas. Uma casa é ocupada permanente, mas os moradores reclamam da falta de serviços e comércios, implicando deslocamentos semanais a Salvador (70km).

O condomínio murado atua como uma barreira para a comunidade local, que praticava a pesca, pois o acesso a praia é dificultado e os percursos aumentados. Símbolos do moderno mundo urbano, o condomínio e seus moradores/usuários direta e indiretamente reestruturam o cotidiano e o modo de vida da comunidade, que agora passa a fornecer serviços para os condôminos, como faxinas, reparos e obras e entretenimento. Nos finais de semana e na temporada de verão fazem longos caminhos para vender na areia da praia cerveja, água de coco, cocada. A pesca e o modo de vida tradicional, relacionados a uma ruralidade fora de moda, foram, em partes, abandonados. A renda de muitas famílias que não se inseriram no 


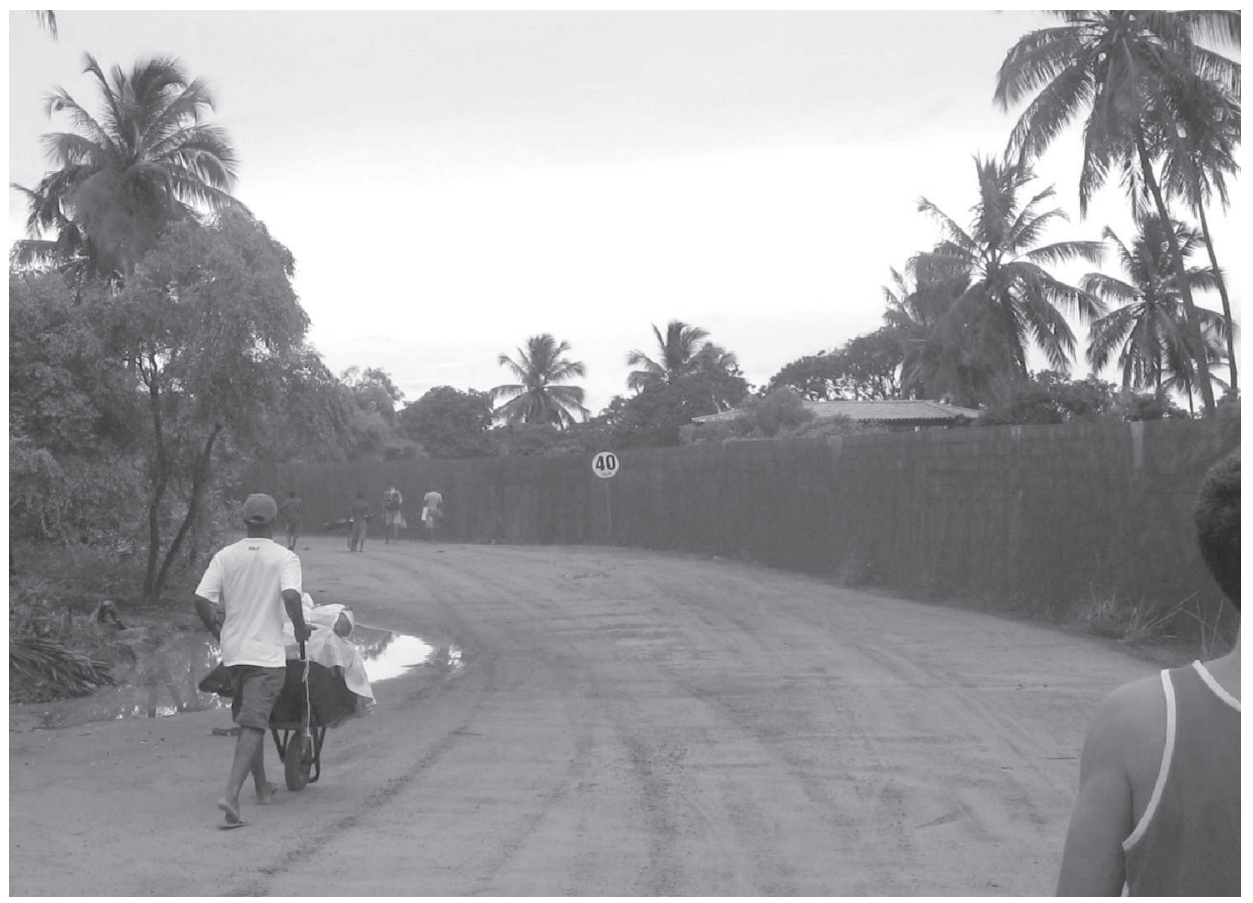

Caminho utilizado pelos usuários do condomínio para chegar a praia (em quadriciclos ou automóveis) e também utilizado pelos moradores do local. Na imagem um morador carrega mercadorias em um carrinho de mão.

mundo dos serviços para o condomínio caiu, muitas perderam suas casas e agora moram nas áreas de risco.

Apesar da perversidade desta forma de produção e apropriação do espaço, é cada vez mais comum observamos os poderes públicos incentivarem e viabilizarem sua difusão, pois estes empreendimentos teriam a força de promover o "desenvolvimento local" de áreas tradicionais, atrasadas e rurais. O que se constata é a imensa força dos agentes do capital imobiliário que comandam, a partir de ordens distantes, a produção de formas parcialmente ocupadas, mas que atuam concorrencialmente sobre um espaço até então produzido e usado sob outras ordens, mais solidárias e cooperativas.

Os agentes do mercado imobiliário nacional e internacional têm agido hegemonicamente na produção do espaço e da natureza, carregando consigo o mundo urbano capitalista, o qual é concretizado e representado na casa, altamente valorizada pela proximidade com a natureza. A oferta de moradias em condomínios fechados, estreitando os lanços da casa e da natureza como mercadorias símbolos de status, anulando a experiência da vida pública, múltipla e diversa. 
Segundo Loureiro \& Amorim (2005),

é deste sonho e da recriação constante de um ideal de morar que a indústria imobiliária se alimenta, possibilitando a introdução constante de novos produtos no mercado que venham satisfazer as expectativas dos consumidores, bem como criar novas necessidades. Neste mercado, a propaganda exerce um papel fundamental, ao manter viva esta necessidade constante pela aquisição de um lugar perfeito para morar [...]

As ações dos diversos agentes do mercado imobiliário que levam a supervalorização de determinados espaços da cidade, com um uso intenso dos recursos do território - naturais (água, ar, paisagem etc.) e artificiais (vias de circulação, transportes etc.) e, criam morfologias urbanas específicas como os condomínios. Em contrapartida, áreas da cidade que não interessam ao mercado imobiliário permanecem à margem dos investimentos públicos e privados.

Nestas relações de uso da natureza e na produção e divulgação de representações da natureza na cidade contemporânea, constata-se uma predominância das questões políticas e econômicas sobre aquelas vinculadas a vida coletiva, a cultura, aos aspectos sociais e a própria constituição da natureza. Recentemente, as maiores empresas do mercado imobiliário brasileiro fizeram grandes captações de recursos na bolsa de valores, objetivando a incorporação de novas áreas e a realização de novos projetos imobiliários, esgotando as áreas disponíveis nas grandes cidades e utilizando muitas áreas até então "verdes". Uma grande empresa do ramo imobiliário de Belo Horizonte, presente também em Salvador, conseguiu captar aproximadamente 600 milhões de reais para construção de empreendimentos de até $50 \mathrm{~m}^{2}$ destinados a famílias com renda entre $\mathrm{R} \$ 700,00$ e $\mathrm{R} \$ 1.200,00$ per capita, que corresponde a aproximadamente $45 \%$ da população brasileira. Os grandes bancos privados e públicos vêm aumentando consideravelmente as linhas de crédito para o financiamento da compra de imóveis pelas classes A, B e C. Apenas um dos maiores bancos privados aumentou a linha de crédito imobiliário de 1 bilhão de reais em 2006 para 3 bilhões de reais em 2008. Muitos dos empreendimentos de alto padrão em Salvador também são financiados com recursos dos bancos públicos.

Na esfera política, os municípios têm aprovado Planos Diretores que viabilizam o investimento do capital imobiliário, impulsionados pelo desejo de aumento de arrecadação de IPTU, pela criação de novos empregos e pelo recebimento de recursos oriundos da outorga onerosa, relacionada com a construção de áreas maiores. Somente em Salvador, a Prefeitura Municipal, estima que 100mil novos empregos sejam criados, R\$ 16 milhões sejam incorporados à arrecadação anual de IPTU e R\$ 

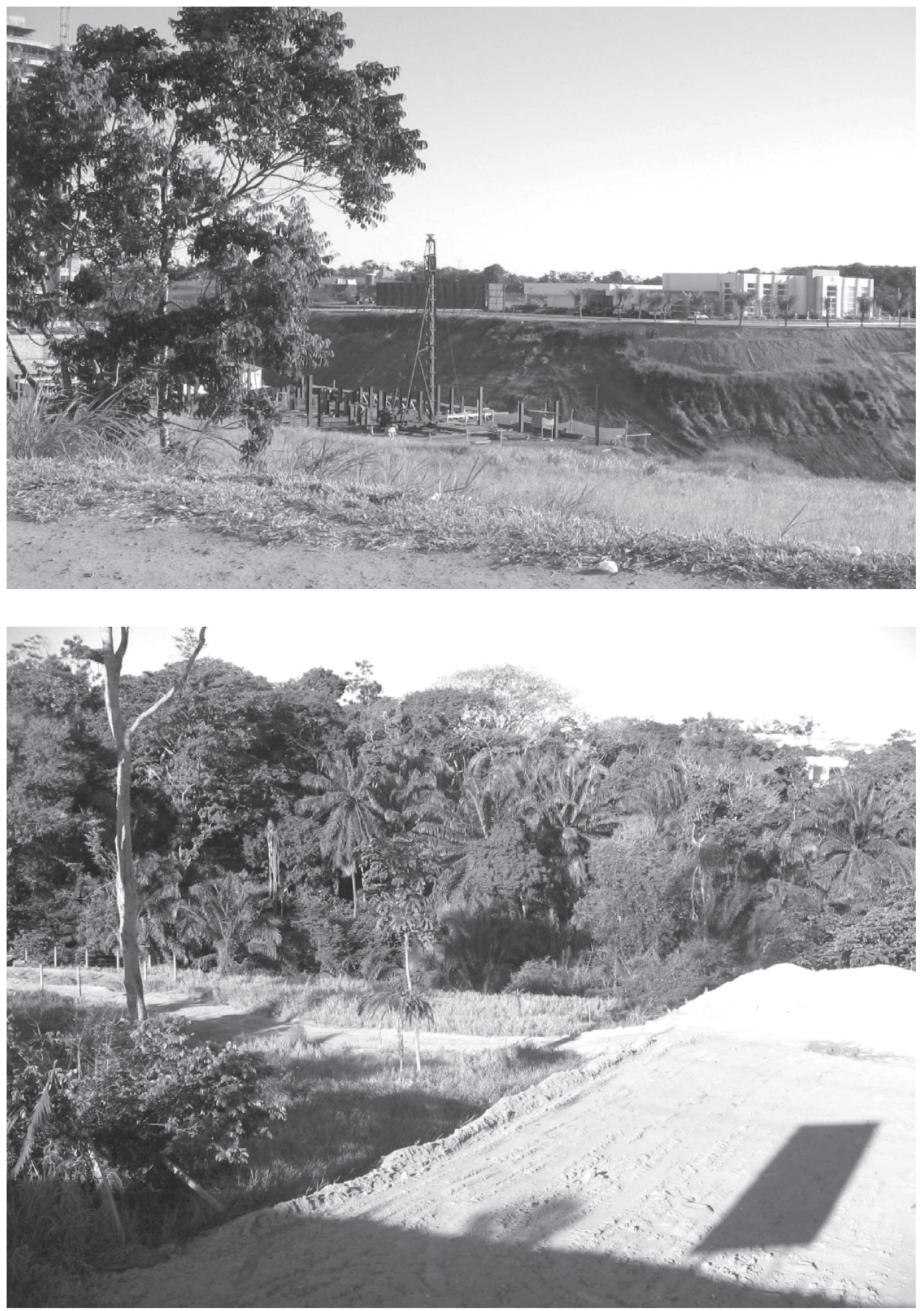

Obras em empreendimentos na Avenida Paralela. Apesar do discurso sobre a natureza, observa-se um avanço da área construída sobre os remanescentes da Mata Atlântica e recursos hídricos (Áreas de Preservação Permanente) 


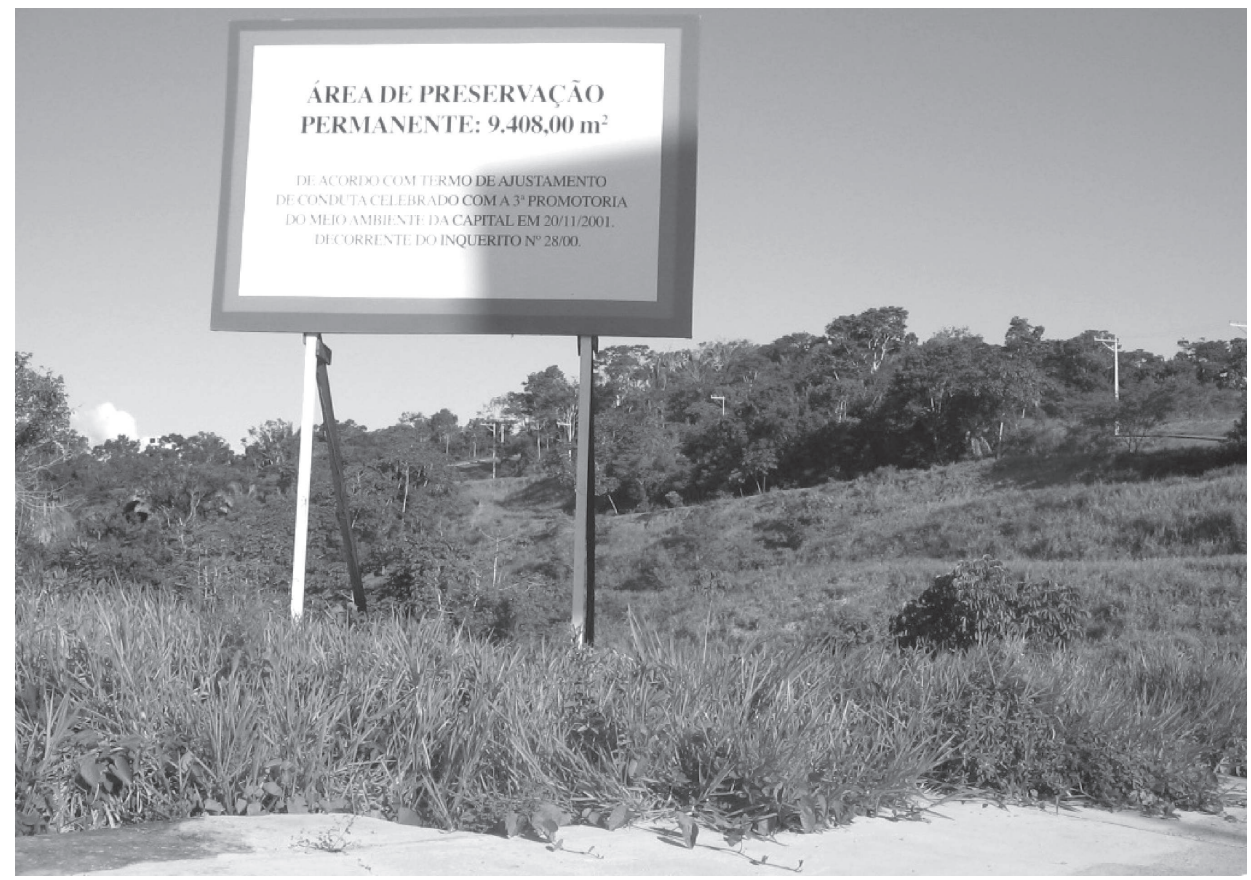

Obras em empreendimentos na Avenida Paralela. Apesar do discurso sobre a natureza, observa-se um avanço da área construída sobre os remanescentes da Mata Atlântica e recursos hídricos (Áreas de Preservação Permanente)

500 milhões entrem na contabilidade da Prefeitura a título de outorga onerosa, apenas em um trecho da orla de Salvador entre o Jardim de Alah e Piatã.

A cidade se prepara para receber grandes investimentos imobiliários, sem muita preocupação no ordenamento e preservação das áreas de reserva da natureza (real). As empresas do mercado imobiliário, altamente capitalizadas, buscam construir mais e desenvolver produtos específicos para determinados nichos de mercado e faixas de renda, para aumentar sua taxa de lucro. Uma grande massa de novos consumidores passa a ter acesso ao crédito para aquisição de imóveis. O resultado é o aumento da demanda por áreas, desenvolvendo novas formas de consumo real e simbólico da natureza na cidade, uma natureza que se torna padronizada.

Perde-se os sentidos na cidade, o corpo cada vez mais vive a deriva ou condicionado ao trânsito e ao tráfego, em vias rápidas, circulando e passando por lugares sem conseguir prestar atenção a cidade e a natureza. Em outros momentos, os congestionamentos e a paisagem "congelada" não oferecem alguma sensação ao olhar. A música do som ou do fone de ouvido apaga qualquer possibilidade de contato com o mundo ou de conversa com o outro. Os cheiros da poluição, da 
fuligem, dos perfumes não permitem que tenhamos os cheiros da cidade e da natureza para completar nossa construção sensitiva das mesmas.

Com toda esta apropriação e mercantilização a NATUREZA na cidade (real e simbolicamente) torna-se um bem privado, cujo acesso e uso passam pelo bolso. De outro lado, aos mais pobres, resta o MATO.

\section{NOTAS}

146 SANTOS (1999, p. 203)

147 "To the corporate executive on the forthieth floor of an office tower, the urban landscape may not be aggressively threatining but aggressively exciting, a symbol of human purpose and power. He may enjoy the presence of trees on the street far below, but that enjoyment may have very low priority with him, especially if the has a lush home in a green suburb. To the clerk leaving an anonymous desk on a lower story, a walk through a park on the way home may be restorative; but the may prefer to elbow his way home by the shortest route to an apartment with a television set and few potted plants on the window sill, or stop off in the purely social landscape of a local bar". (GREENBIE, 1988, p. 73)

${ }^{148}$ O município de Florianópolis se divide em duas porções, uma insular e outra continental. A primeira abrange a área da ilha de Santa Catarina, onde se concentram os balneários, os bairros de alto padrão, os centros comerciais, administrativos estaduais e municipais e as universidades. Já na parte continental abrange poucos bairros e havia perdido seu destaque com o fechamento da ponte Hercílio Luz (de aço) pelas pontes da via expressa que cortam o município de São José. Atualmente, com a saturação da Ilha e a sua hipervalorização, os bairros do Continente - Abraão, Coqueiros e Estreito - novamente passam a ser alvo do mercado imobiliário, para atendimento da classe média que não consegue mais comprar imóveis na Ilha.

149 Pode se inferir uma segregação socioespacial no aglomerado urbano de Florianópolis (Grande Florianópolis), com a concentração das pessoas com maior renda na parte insular e as menores rendas nos municípios continentais. Isto se dá em função dos preços dos imóveis e da sua recente super valorização, que repelem e expulsam as populações mais pobres da ilha.

${ }^{150} \mathrm{O}$ chefe da família, geralmente empresário, trabalha durante a semana em São Paulo, vindo para Florianópolis (50 minutos de avião) aos finais de semana para ficar com sua família, que reside em Jurerê.

${ }^{151}$ A título de curiosidade sobre o traçado urbano, as ruas e avenidas foram batizadas com motivos marinhos, principalmente nomes da fauna, como por exemplo: Av. das Moréias, Rua das Baleias Franca, Av. das Arraias, Passeio dos Namorados etc. 


\title{
O DIREITO À NATUREZA NA CIDADE. Da (des)ideologização da prática para a consciência crítica da praxis na relação com a natureza
}

\begin{abstract}
a busca da utopia é algo de ancestral e companheiro do homem, porque o que distingue o homem dos outros animais não é esse dedão, é exatamente o fato de que ele é portador de utopia. Eu sei que hoje se costuma ridicularizar quem fala em utopia, mas não me preocupo em insistir que sem ela não vale a pena viver, e sem ela tão pouco é possível pensar, porque o pensamento não é produzido a partir do que houve, nem do que há.
\end{abstract}

SANTOS, 2000d - Conferência Magna

\section{A CRÍTICA - DESVELANDO A IDEOLOGIA DA PRÁTICA ALIENADA}

Em grande parte da história, sistemas de ideias, objetos e conceitos que permitiriam uma análise histórica do processo de incorporação da natureza à vida social, tratada epistemologicamente, observou-se a predominância da ação humana sobre a natureza como um projeto coletivo de emancipação social dos contingenciamentos da natureza. Segundo Reclus (1886), a tomada de consciência da ação humana coletiva sobre o meio natural propiciou a emancipação dos homens e lhes deu liberdade. Graças a este projeto de emancipação coletivo, o homem não mais remanesce como mero produto do planeta. 
Entretanto, a partir do século XVIII e XIX com magnitude ampliada no século XX e nos dias atuais, partiu-se para uma valorização do projeto de realização ou satisfação pessoal em detrimento das ações coletivas. A propriedade privada e o individualismo, resultantes da hegemonia capitalista e da busca de uma felicidade capitalista, baseada no consumismo, marcam de maneira definitiva as relações entre o homem e a natureza, sendo que esta passa a ser incorporada ao território, como uma natureza socializada.

Em função da apropriação privatizada da natureza na cidade, torna-se premente a busca de ideias e ações que resgatem os projetos coletivos sobre e com a natureza, um verdadeiro manifesto em prol da natureza na cidade, local de concentração de grande parte da população no mundo contemporâneo, que seja produzida e apropriada socialmente. Nesta direção, o que se apresenta será norteado por um direito igualitário de natureza para todos e não a manutenção de espaços segregados com a presença de natureza, uma natureza humanizada e transformada e, até mesmo produzida, como um objeto de consumo para classes economicamente mais abastadas.

Segundo Santos (1987), assiste-se a uma glorificação do consumo na mesma proporção que uma glorificação do individualismo cruel e opressor, que destrói os traços da individualidade, da personalidade, levando, assim, a uma padronização do consumo, dos desejos, dos ideais e a uma perda da diversidade que é uma das riquezas da vida em sociedade ${ }^{152}$.

\begin{abstract}
O direito individual não tem relação com o vulgar interesse privado. Este, que satisfaz a uma minoria condenando o resto da massa social a uma vida medíocre, merece severas restrições. Ele deve ser, em todas as partes, subordinado aos interesses coletivos, tendo cada indivíduo acesso às alegrias fundamentais: o bem-estar do lar, a beleza da cidade. (item 95, Carta de Atenas)
\end{abstract}

No mundo do consumo, a produção da natureza vincula-se à instauração de um modelo de produção de objetos associados a uma economia capitalista, criando um mundo de objetos prenhes de intencionalidades e significações. Além disto, esta produção de objetos acontece em escala mundial ${ }^{153}$.

A cidade é marcada pela ausência da vida e da natureza, enclausurada em locais exclusivos. Pode ser usada a ideia da cidade subterrânea de Munford (1998, p. 520), onde tudo é artificial, inclusive a luz e o ar. Uma cidade "subterrânea", uma cripta, um tumulo da civilização.

$\mathrm{Na}$ cidade sitiada pelo consumo, o lugar de encontro (do coletivo), lugar da troca (das experiências), é reduzido, segundo Lefebvre (1969), ao mercado. Nesta 
centralidade urbana do capitalismo, a cidade como lugar de consumo aproxima a natureza pelo preço. Os signos da natureza e da cidade se convertem em signos de satisfação e alegria (individual). As necessidades e os desejos individuais são motivados pelo consumo. A água, o ar puro - ou menos poluído -, as árvores, os animais, os parques tornam-se objetos de consumo - e o que torna a situação ainda mais grave, e que, devido a sua raridade, em alguns lugares, estes elementos da natureza passam a ser considerados artigos de luxo ${ }^{154}$. Segundo Santos (2000a, p. 48) "quem não pode pagar pelo estádio, pela piscina, pela montanha e o ar puro, pela água, fica excluído desses bens, que deveriam ser públicos, porque essenciais".

Aparece, dessa forma, o consumidor que ocupa o lugar do cidadão, e sua busca desenfreada pelos objetos que irão satisfazer suas necessidades e desejos. Nunca na história do homem os objetos, incluindo a natureza na cidade foram tão prenhes de intencionalidade, criados especificamente como portadores de um objetivo previamente definido. Estabelece-se, assim, um par contraditório na incorporação da natureza - como um projeto de emancipação coletiva ou como um projeto de satisfação individual ${ }^{155}$.

\section{OS PRINCÍPIOS - PARA UMA NOVA PRÁXIS NA RELAÇÃO COM A NATUREZA, A NATUREZA PARA O CIDADÃO E NÃO PARA O CONSUMIDOR.}

É necessário definir um caminho, a partir da ação do homem sobre a natureza em sua vida cotidiana, avançando na direção de sua emancipação coletiva sobre os desígnios e controles da natureza. Aquilo que para muitos poderia ser considerado uma visão antropocêntrica, é considerada neste livro como uma visão otimista da humanidade, um elogio à capacidade que os homens erigiram ao longo de sua história. Invertendo sua relação com a natureza, da qualidade de subjugados à de libertos deste domínio que a natureza impunha aos homens e considerando a produção social da natureza e sua apropriação também coletiva.

Na concepção otimista da ação humana sobre natureza, não se nega que, em alguns momentos, houve uma grande transformação da natureza. Em alguns casos como resultado da necessidade de estabelecimento da sociedade humana em determinados territórios e, em outros, apenas como consequência da exploração da natureza para satisfação de poucos indivíduos. No primeiro caso, um processo de emancipação coletiva e, no segundo, apenas a satisfação individual. A hipótese que se forma para explicar este aparente descontrole em relação à força da ação imposta sobre a natureza é fruto de uma mudança de perspectiva de futuro para a huma- 
nidade. O domínio e controle sobre a natureza tornaram-se não mais uma possibilidade de emancipação coletiva de toda a sociedade, mas sim uma forma de satisfação individual de alguns. No presente momento histórico, marcado pelo modo de produção capitalista, a busca pela satisfação das necessidades e desejos pessoais, atrelados ao status que o consumo proporciona, é cada vez mais evidenciado na relação do homem com a natureza.

Uma das questões centrais na relação entre emancipação coletiva e realização individual, no que diz respeito à temática da natureza aqui tratada, é a constatação, no período atual, da ascensão da satisfação pessoal para o entendimento do valor da natureza, exemplificado através da análise dos empreendimentos imobiliários. Assim, como a doutrina cristã de dominação da natureza; as ideias iluministas de dominação, controle e humanização da natureza; as ideias de Descartes, Bacon e Marx sobre a natureza; Harvey (1996) acrescenta a dissociação entre o homem e a natureza tanto como uma chave para desvendar os segredos da natureza como para facilitar a emancipação e a realização pessoal, bem como para observar a perda de contato com a natureza após o século XIX, ou o desencantamento do mundo ${ }^{156}$.

A imposição da satisfação individual também levou a natureza a ser entendida como objeto de consumo e o homem como consumidor. A constatação da instalação do ideal do consumo em todas as esferas da vida social é a grande perversão do período atual, que tem o poder de transformar o cidadão em consumidor. Uma das formas de superação da busca desenfreada pela satisfação individual dar-se-ia na instauração de um Período Popular na História (uma forma de emancipação coletiva). O dado imprescindível para a leitura geográfica do período popular, a partir de algumas ideias de Milton Santos(1997), é o entendimento do espaço como realidade relacional, a partir da natureza mediatizada pelo trabalho da sociedade.

O espaço deve unir os homens entre si e com a natureza, mesmo uma natureza já plenamente socializada que pode se tornar ainda mais rica e interessante do que aquela natureza bruta. Um espaço cheio de vida, um espaço para todos e não um espaço excludente. No caso da natureza, esta deveria passar, além de sua desfetichização, por um processo de desmistificação da sua aura romântica (vinculada) e ser definitivamente entendida como um elemento integrado à vida social, ao cotidiano da cidade, fruto de uma história social construída pelo trabalho humano e por vários sistemas de ideias.

Além da superação filosófica da satisfação pessoal pelo retorno da emancipação coletiva, deve-se pensar formas materiais de mudar o quadro classista, excludente e segregador em que se encontra a natureza na cidade. Segundo Munford (1998), é preciso repensar a cidade não como uma máquina, mas como o local da vida do 
homem, restituindo a vida como finalidade da vida urbana. É preciso habitar a cidade, participar da vida coletiva social. A cidade é o espaço e o lugar para a (re)valorização do processo de emancipação coletiva ${ }^{157}$.

Para Le Corbusier, no item 75 da Carta de Atenas, a

liberdade individual e ação coletiva são os dois pólos entre os quais se desenrola o jogo da vida. Todo empreendimento cujo objetivo é a melhoria do destino humano deve levar em consideração esses dois fatores. Se ele não chega a satisfazer suas exigências, frequentemente contraditórias, condena-se a um inevitável fracasso. É impossível, em todo caso, coordená-los de maneira harmoniosa se não se elabora, de antemão, um programa cuidadosamente estudado e que nada deixe ao acaso.

A visão otimista, ou utópica, das relações entre o homem urbano e a natureza na cidade, baseada na necessidade da presença da natureza em toda a cidade e para todas as classes sociais, está fundada no entendimento e na prática da Geografia, na qual, de acordo com Santos (1978, p. 219)

os geógrafos, ao lado de outros cientistas sociais, devem se preparar para colocar os fundamentos de um espaço verdadeiramente humano, um espaço que una os homens por e para o seu trabalho, mas não para em seguida os separar em classes, entre exploradores e explorados; um espaço matéria inerte trabalhado pelo homem, mas não para se voltar contra ele; um espaço natureza social aberta a contemplação direta dos seres humanos, e não um artifício; um espaço instrumento de reprodução da vida, e não uma mercadoria trabalhada por uma outra mercadoria, o homem artificializado.

\section{O PROJETO - UM NOVO DESÍGNIO: REPENSAR A CIDADE É REPENSAR O LUGAR DA NATUREZA NA CIDADE}

Para alcançar uma mudança nas ideias e práticas que os homens produzem e vivem nas cidades contemporâneas, foram elaboradas 10 proposições:

1) Épreciso criar um direito à natureza na cidade, como um direito coletivo, e não como forma de anulação da cidade ${ }^{158}$ e de retorno à natureza primi- 
tiva. Este direito emerge como um apelo ou exigência, e não deve ser resumido a um direito à vista (panorama ou entendimento da natureza apenas como paisagem).

2) É preciso renovar a liberdade criadora e destruir a ideologia do consumo e, segundo Lefebvre (1969), produzir um novo humanismo, um humanismo do homem urbano.

3) É preciso que a natureza na cidade seja para e de todos independente do poder aquisitivo. A natureza não pode ser um objeto de consumo para alguns moradores das cidades. Não é mercadoria de luxo nem objeto de decoração para condomínios de alto padrão, pois deve haver um domínio coletivo sobre a natureza material. De acordo com Le Corbusier (Carta de Atenas - item 10), "condenar-se-ia um açougueiro que vendesse carne podre, mas a legislação permite impor habitações podres às populações pobres". A natureza na cidade deve ser um direito de todos, mas não é incluída nos planos urbanísticos dos bairros ou habitações para as classes mais pobres, apesar da legislação prever a reserva de áreas nos loteamentos para a construção de áreas verdes.

4) É necessário publicizar/desprivatizar a natureza, mudando a prática corrente na qual alguns empreendimentos imobiliários de alto padrão apresentam reservas de "natureza" em suas áreas, um espaço restrito aos seus moradores, enquanto nas áreas mais pobres das cidades, além da negação da natureza primeira, assiste-se a um banimento até mesmo da segunda natureza, como, por exemplo, na falta de áreas verdes. A natureza na cidade não pode ser um privilégio apenas daqueles com poder aquisitivo para comprá-la, preservá-la ou produzi-la, não se pode configurar com um produto raro a ser consumido apenas pelos habitantes das cidades com dinheiro suficiente para comprar imóveis de luxo.

5) É preciso regatar a ideia de totalidade da natureza na cidade, superando a sua redução como sinônimo de área verde; a natureza deve ser vista como algo maior que as árvores, arbustos e gramas. O direito à natureza na cidade deve ser ampliado e entendido como o direito coletivo à qualidade do ar, da água, à vida em comunidade, à fauna urbana etc.

6) É necessário entender a natureza na cidade como obra para e pelo bomem, através da superação da ideia que a natureza na cidade é um refúgio de uma natureza que não existe mais, nem deve ser um enclave no tecido urbano protegido com uma redoma e separado da vida citadina. A natureza hoje é também obra social e está incorporada à vida humana, portanto, devem-se usar e viver os espaços da natureza na cidade; é pre- 
ciso socializar o seu uso, tornar a natureza ainda mais utilizável como local de encontro.

7) É preciso educar/conscientizar os urbanistas para que tratem a natureza nas cidades, fazendo-as "cidades verdes", e não como jardim particular das casas e condomínios, mas sim pensada, visando à sua utilização coletiva. De acordo com o item 35 da Carta de Atenas, sobre os bairros residenciais, "[...] os volumes edificados serão intimamente amalgamados às superfícies verdes que os cercam. [...] De qualquer modo, a textura do tecido urbano deverá mudar; as aglomerações tenderão a tornar-se cidades verdes."

8) É preciso instaurar a apropriação da natureza na cidade sob a égide do conceito de valor de uso e não do valor de troca ${ }^{159}$. Segundo Lefebvre (1969, p.12) "a cidade e a realidade urbana dependem do valor de uso. O valor de troca e a generalização da mercadoria pela industrialização tendem a destruir, ao subordiná-las a si, a cidade e a realidade urbana.” A natureza entendida como um valor de uso não seria passível de mercantilização pelos empreendedores imobiliários gananciosos pela valorização de seus imóveis e responsáveis, desta maneira, pela segregação espacial e econômica da natureza na cidade. Assistir-se-ia a uma valorização da natureza pelo seu conteúdo utilizado pela sociedade, uma natureza verdadeira incorporada ao território usado, um território usado por todas as pessoas da cidade.

9) É preciso coibir a prática atual de que a cidade e a natureza se transformem em bens privados, privatizando-se tradicionais bens públicos. A água que em muitas cidades passa a ser tratada e distribuída por empresas privadas; os parques e as praças adotadas por supermercados e firmas estrangeiras que acreditam no direito (adquirido pela concessão) de cercar as áreas públicas e inundá-las com suas propagandas ${ }^{160}$, muitas vezes, cobrando ingresso pela entrada. A natureza na cidade está ameaçada de ser privatizada.

10) Épreciso produzir uma natureza na cidade, entendendo-a como uma natureza bumanizada, cuja totalidade torna obsoleta a tradicional dicotomia ente ambiente construído $x$ ambiente "natural", que não relembre os tempos de escassez/carestia do início da civilização e que não seja vinculada ao economicismo do tempo presente. A presença da natureza na cidade não deve também ser uma volta à natureza como foi pensada no século XIX pelo romantismo europeu e americano ${ }^{161}$. 


\section{A AÇÃO - UM PARQUE URBANO PARA O USO COLETIVO DA NATUREZA NA CIDADE}

Como proposta de ação, toma-se um exemplo em Florianópolis, cidade atualmente subordinada a uma pressão constante pela incorporação de novas áreas à mancha urbana, operada por um mercado imobiliário em franca expansão. Novas construções de casas e edifícios residenciais têm sido um elemento altamente presente na paisagem da Ilha de Santa Catarina.

Este processo intenso de urbanização no município tem levado à utilização de áreas verdes para construção, fazendo com que haja uma sensível redução da natureza na cidade. Além disto, muitas dessas áreas estão sendo apropriadas pelos loteamentos, que se pretendem loteamentos fechados, e pelos condomínios.

Um dos casos em curso na cidade diz respeito a uma área denominada Morro do Goulart, numa das áreas onde a expansão urbana e a especulação imobiliária se fazem mais presente, no bairro João Paulo, antigo bairro Saco Grande. Contraditoriamente ao processo observado, cada vez mais se mostra uma necessidade de manutenção e mesmo de ampliação da natureza na cidade, tanto em função da qualidade ambiental que estas áreas propiciam, quanto do ponto de vista estético, paisagístico e social. A estética e a qualidade de vida são prerrogativas, há longa data, no urbanismo, conforme pode ser observado nos capítulos anteriores deste livro. Portanto a natureza, imbuída e valorada pelo seu conteúdo estético, será altamente incorporada à vida econômica da sociedade.

No caso da área em questão, o Morro do Goulart, as características do sítio propiciam uma grande beleza cênica. Esta beleza e o uso desta área não podem ser privatizados com a construção de qualquer tipo de loteamento ou condomínio. Seu uso deve ser mantido público, pois a natureza na cidade deve ser um bem social, portanto um bem coletivo e público. O que se deve propor para esta área é a sua utilização, mantendo as características da vegetação do sítio, como a Mata Atlântica e o manguezal.

As superfícies verdes, que se terá intimamente amalgamado aos volumes construídos e inserido nos setores habitacionais, não por função única o de embelezamento da cidade. Elas deverão, antes de mais nada, ter um papel útil e as instalações de caráter coletivo ocuparão seus gramados: creches, organizações pré ou pós-escolares, círculos juvenis, centros de entretenimento intelectual ou de cultura física, salas de leitura ou de jogos, pistas de corrida ou piscina ao ar livre. Elas serão o prolongamento da habitação e, como tal, deverão estar subordinadas ao estatuto do solo. (LE CORBUSIER - item 37 - Carta de Atenas) 


\section{Croqui com a proposta do Parque Urbano da Ponta do Goulart - Florianópolis/SC}

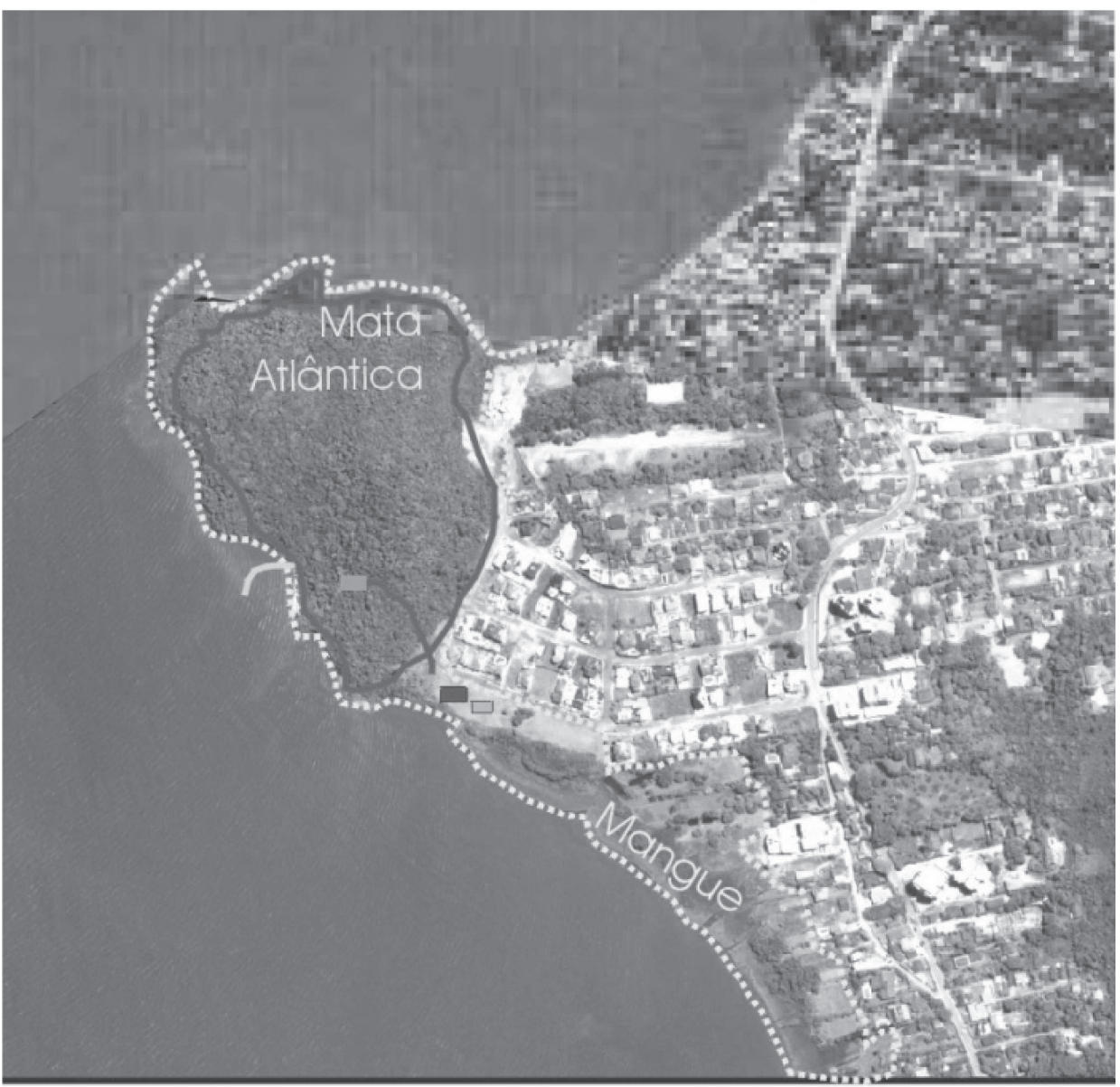

LEGENDA

\begin{tabular}{|c|c|}
\hline & LIMITE DO \\
\hline- & TRILHAS \\
\hline & DECK \\
\hline 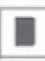 & SEDE \\
\hline 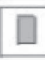 & SANITÁRIOS \\
\hline 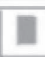 & MIRANTE \\
\hline
\end{tabular}

Base: imagem orbital Quickbird, 2003 fotografia aérea, 1998 Elaboração: Wendel Henrique 
A ação que se propõe é a criação de um parque urbano como forma de dar uma utilização para a área, respeitando suas características físicas e propiciando mais um local público para a população de Florianópolis. A criação do parque no sítio onde é proposto visa não apenas a delimitação da vegetação como área verde recreacional, mas também das águas da Baía Norte para lazer da população. Sua materialização requer apenas esforços simples de adequação do local para o fluxo de pessoas que se espera com a dotação de pequena infra-estrutura para visitação.

As adequações e construções a serem realizadas na área, visando à criação do Parque, seriam:

- trilhas remodeladas e sinalizadas, indicando o grau de dificuldade a ser vencido;

- recipientes coletores de lixo ao longo da trilha e nas áreas receptoras dos visitantes;

- sanitários;

- plantio de espécies nativas próximas uma das outras, arbustos com folhagem densa ou bromeliáceas espinhentas ao longo da trilha, constituindo uma cerca verde para evitar que os visitantes saiam da área aberta para visitação e penetrem na mata mais densa, que deve ser preservada na alta vertente;

- construção de um mirante no topo da área com vistas para o Morro da Cruz, Agronômica e área continental;

- outras obras que poderiam ser construídas para embelezamento do parque seriam um trapiche ou $d e c k$, onde seriam instalado equipamento para a realização de pequenos lanches.

Todas estas ações estão de acordo com o Estatuto da Cidade (2001) que "estabelece normas de ordem pública e interesse social que regulem o uso da propriedade urbana em prol do bem coletivo, da segurança e do bem-estar dos cidadãos, bem como do equilíbrio ambiental." (Art. $1^{\circ}$ - parágrafo único). O Estatuto da Cidade também mostra claramente a necessidade da vida urbana estar em contato com a natureza deve se manter uma relação próxima com esta natureza na cidade, a qual não pode ser entendida apenas como um "amontoado" de árvores ou mato.

A área do Parque Urbano da Ponta do Goulart, além de servir como uma área pública de natureza, que poderia ser utilizada por grupos escolares para estudos sobre a cidade e a natureza na Ilha de Santa Catarina ou trabalhos de educação ambiental. Estudantes universitários de diversos cursos, como Geografia, Biologia, 
Pedagogia, Turismo e Oceanografia poderiam ser convidados a trabalharem como monitores destes grupos, elaborando aulas de campo e construindo um conhecimento prático importante nos dias atuais.

[...] Não se trata mais de simples gramado cercado a casa, com uma ou outra árvore plantada, mas verdadeiros prados, de bosques, de praias naturais ou artificiais, constituindo uma imensa reserva cuidadosamente protegida, oferecendo mil oportunidades de atividades saudáveis ou de entretenimento útil ao habitante da cidade. (LE CORBUSIER - item 38 - Carta de Atenas)

Desta forma, a área do Morro do Goulart, no bairro João Paulo, em Florianópolis, não deve ser esquecida, cercada ou desmatada para loteamentos ou para a construção de casas, pois as características do seu sítio lhe conferem várias alternativas interessantes de uso.

A ideia da utilização desta área, poderia ser extrapolada para outras áreas urbanas, visando à criação, aproveitamento e utilização da natureza na cidade de forma coletiva, num parque urbano público, aberto a toda a população. Desta forma, superam-se dois problemas. O primeiro diz respeito a uma característica das áreas verdes sem manutenção e sem uso, pois nos trópicos a natureza (áreas verdes) acaba por se transformar em "mato", e a presença do mato é sempre um motivo para desmatamento, queimadas e consequente destruição, sendo usado o discurso da limpeza da área para evitar a proliferação de insetos e animais transmissores de doenças, como acontece em Salvador com o aterramento de lagoas para se evitar a reprodução do mosquito da dengue ou a infestação dos condomínios pelo barbeiro (transmissor da Doença de Chagas). A natureza/mato, nos discursos, também serve de esconderijo de marginais e o uso do mato como local para o consumo de drogas. O segundo problema a ser resolvido com a criação do parque é a garantia de acesso à área por todos os moradores da cidade, evitando-se, assim, que o "pontão" do Morro do Goulart transforme-se no quintal de um condomínio, tendo seu acesso restrito aos seus moradores, excluindo outros que deveriam ter o mesmo direito a este bem, atualmente público.

A natureza na cidade deve ser valorizada não pelo seu caráter mitológico ou como forma de apresentação material da superioridade do homem sobre seus ritmos e fluxos, mas como uma obra socialmente construída duramente ao longo da história da humanidade.

A natureza na cidade deve ser a representação de uma ideia de liberdade, independência e emancipação coletiva. O entendimento, a incorporação e a produ- 
ção da natureza, bem como as formas de se pensar a natureza hoje, devem estar atrelados à perspectiva ou à constituição de um novo sentimento pela natureza, não baseado na sua exploração visando o conforto individual, mas sim na emancipação coletiva. Uma utopia, mas uma utopia de esperança, pela construção de um mundo melhor.

\section{NOTAS}

${ }^{152}$ Esta constituição de um individualismo exacerbado irá produzir uma dependência do consumidor ao novo mundo dos objetos, o que "limita sua vocação para obter uma individualidade e reduz as possibilidades dos encontros interpessoais diretos e enriquecedores, simbólicos em sua própria origem. A comunicação entre as pessoas é frequentemente intermediada por coisas. [...] A socialização capitalista, originária da divisão de trabalho que a monetarização acentua, impede movimentos globais e um pensamento global. A reivindicação de uns não raro representa um agravo para o outro. A força da alienação vem dessa fragilidade dos indivíduos, quando apenas conseguem identificar o que os separa e não o que os une". (SANTOS, 2000a, p. 17)

${ }^{153}$ De acordo com Santos (1985), "a expressividade da forma veio chocar-se com dois inimigos principais: os modelos universais e a semantização universal. Trata-se, de fato, de processo e resultado, tendo como causa motriz a necessidade de transformar tudo em valor de troca. [...] É o objeto manufaturado, carregado de significações 'atribuídas', falseado por uma significação das coisas para além das próprias coisas, é a arquitetura como mass media, prenhe de intencionalidades e simbolismo". (1997, p. 24)

${ }^{154}$ Também se deve estar atento para a mercantilização da natureza. "O direito à natureza (ao campo e à 'natureza pura') entrou para a prática social há alguns anos em favor dos lazeres. [...] a natureza entra no valor de troca e para a mercadoria; é comprada e vendida. Os lazeres comercializados, industrializados, organizados institucionalmente destroem essa 'naturalidade', da qual as pessoas se ocupam a fim de traficá-la e trafegar por ela. A 'natureza', ou aquilo que é tido como tal, aquilo dela sobrevive, tornase o gueto dos lazeres, o lugar separado do gozo, da aposentadoria da 'criatividade'." (LEFEBVRE, 1969, p. 107-108)

155 "Isolado o homem sente-se desarmado; por isto liga-se espontaneamente a um grupo. Entregue somente as suas forças, ele nada construiria além de sua choça e levaria, na insegurança, uma vida submetida a perigos e fadigas agravados por todas as angústias da solidão. Incorporado ao grupo, ele sente pesar sobre si o constrangimento de disciplinas inevitáveis, mas, em troca, fica protegido em certa medida contra a violência, a doença, a fome: pode aspirar sua moradia e satisfazer sua profunda necessidade de vida social [...] Se os empreendimentos do grupo são sábios, a vida do indivíduo é ampliada e enobrecida. Se a preguiça, a estupidez e o egoísmo o assolam o grupo, enfraquecido e 
entregue à desordem, só traz a cada um de seus membros rivalidades, rancor e desencanto". (LE CORBUSIER - item 2 - Carta de Atenas)

${ }^{156}$ Nesta relação entre emancipação e satisfação, Harvey (1996) cita um exemplo, a transformação da natureza - sua humanização através do paisagismo/jardinagem. Esta torna-se um dos meios privilegiados não apenas resgatando o que parecia ter sido perdido, mas definindo um futuro para a humanidade no qual a realização pessoal poderia ser apenas alcançada pela liberação dos sentidos humanos para a experiência sublime e transcendental de ser um com o mundo.

157 "A missão final da cidade é incentivar a participação consciente do homem no processo cósmico e no processo histórico. Graças a sua estrutura complexa e durável, a cidade aumenta enormemente a capacidade de interpretar estes processos e tomar neles uma parte ativa e formadora, de tal modo, que cada fase do drama que desempenhe, vem a ter, no mais elevado grau possível, a iluminação da consciência, a marca da finalidade, o colorido do amor. Esse engrandecimento de todas as dimensões da vida, mediante a comunhão emocional, a comunicação racional e o domínio tecnológico, e, acima de tudo, a representação dramática, tem sido na história a suprema função da cidade. E permanece como a principal razão para que a cidade continue existindo.” (MUMFORD, 1998, p. 621)

${ }^{158}$ Lefebvre (1969) mostra um certo receio ao direito à natureza; segundo o autor, "a necessidade e o 'direito' à natureza contrariam o direito à cidade sem conseguir iludi-lo. (Isto não significa que não se deva preservar amplos espaços 'naturais' diante das proliferações da cidade que explodiu.).” p.108

159 Valor de Troca - "Valor pelo qual um artigo é trocado no mercado. Segundo a teoria do valortrabalho de Marx (aperfeiçoada), o valor de troca de uma mercadoria é determinado pela quantidade socialmente necessária de trabalho não qualificado indispensável para sua reprodução com determinada produtividade média social do trabalho, e medido pelo tempo de trabalho (horas ou dias) necessário para sua produção." (MANDEL, 1985, p. 415-416)

Valor de Uso - "Utilidade de uma mercadoria para satisfação de uma necessidade específica de seu comprador. Artigos que não têm valor de uso para ninguém não podem ser trocados ou vendidos. Por extensão, a produção pura e simples de valores de uso, ao contrário da produção de mercadorias, é produção de bens para o consumo de seus produtores diretos, ou unidades coletivas desses produtores." (MANDEL, 1985, p. 416)

${ }^{160}$ É triste andar por uma cidade e ver as pobres árvores recém plantadas cercadas por telas e placas de alumínio usadas para divulgação de propaganda. Com o discurso da salva-guarda do vandalismo juvenil a natureza na cidade se torna um outdoor para marcas e publicidade da responsabilidade ambiental de empresas privadas.

${ }^{161}$ Conforme escreve Smith (1988), no século XIX “o movimento de 'volta à natureza' era a resposta não dos desbravadores do sertão, mas dos habitantes urbanos: a valorização da natureza selvagem começou nas cidades. O literato, segurando uma caneta, não o pioneiro com seu machado, é que fez os primeiros gestos de resistência contra as fortes correntes de antipatia. [...] Domesticada, higienizada e estendida sobre as mesas de café, a natureza era um pertence, da mesma forma como o gato da família”. 



\section{IX - REFERÊNCIAS}

ABREU, Maurício de Almeida. A cidade, a montanha e a floresta. In: ABREU, M. A. (Org.). Natureza e sociedade no Rio de Janeiro. Rio de Janeiro: Prefeitura Municipal do Rio de Janeiro, 1992, p. 54-103.

BACHELARD, Gaston. A epistemologia. Lisboa: Edições 70, 1971.

BACON, Francis. Novum organum ou verdadeiras indicações da Interpretação da natureza. São Paulo: Nova Cultural, 1999. (Coleção Os Pensadores)

BRASIL. Estatuto da Cidade. Lei Federal 10.257. Diário Oficial da União, 10 de julho de 2001.

BUARQUE, Cristovão. O pensamento em um mundo. Terceiro Mundo. In:

BURSZTIYN, Marcelo (Org.). Para pensar o desenvolvimento sustentável. São

Paulo: Ed. Brasiliense, 1993, p.57-80.

BUFFON, Georges Louis Leclerc. Histoire Naturelle. Pages Choisies. Paris: Librairie Larousse, 1934.

BUFFON, Georges Louis Leclerc. Les époques de la nature. Pages Choisies. Paris: Librairie Larousse, 1934.

CALVINO, Ítalo. Marcovaldo ou as estações na cidade. São Paulo: Companhia das Letras, 1994.

CALVINO, Ítalo. As cidades invisíveis. São Paulo: Companhia das Letras, 1999.

CAPEL, Horácio. La Morfología de las Ciudades. (Sociedad, cultura y paisaje urbano). Barcelona: Ediciones del Serbal, 2002.

CARVALHO, Pompeu Figueiredo de. The Capitalist System. Background to regional planning in Iberia. Edimburgo: University of Edimburg, 1983. (Dissertação de Mestrado)

CARVALHO, Pompeu Figueiredo de. Águas nas cidades: reflexões sobre usos e abusos para aprender novos usos. In: CARVALHO, P. F. \& BRAGA, R. Recursos 
hidricos e planejamento urbano e regional. Rio Claro: Laboratório de Planejamento Municipal - Deplan/UNESP, 2003, p. 09-36.

CASINI, Paolo. As filosofias da natureza. Lisboa: Presença, 1975.

CÍCERO, Marcus Tullius. The Nature of the Gods. Harmondsworth: Penguim, 1972.

CÍCERO, Marcus Tullius. De la Nature des Dieux. Paris: Panckoucke, s/d

CHAUÍ, Marilena. O que é ideologia. 14ª ed. São Paulo: Ed. Brasiliense, 1984.

CHOAY, Françoise. O urbanismo. Utopias e realidades: uma antologia. São

Paulo: Ed. Perspectiva, 1992.

DUARTE, Rodrigo A. de Paiva. Marx e a natureza em o capital. São Paulo: Loyola, 1986.

ENGELS, Friedrich. Anti-Duhring. 3. ed. Rio de Janeiro: Paz e Terra, 1990.

ENGELS, Friedrich. A dialética da natureza. 3. ed. Rio de Janeiro: Paz e Terra, 1991.

FÉRNANDEZ-ARMESTO, F. Civilizations. Culture, Ambition, and the

Transformation of Nature. New York: The Free Press, 2001.

FLORIANÓPOLIS (Prefeitura). Plano Diretor do Distrito Sede. Florianópolis: IPUF, 1998.

FOUCAULT, Michel. Microfísica do poder. 15. ed. Rio de Janeiro: Graal, 2000.

FROMM, Erich. Conceito marxista de homem. 2. ed. Rio de Janeiro: Zahar Editores, 1962.

GARAUDY, R.; MARX, Karl. Paris, 1967. In: SODRÉ, Nelson Werneck. Fundamentos do materialismo dialético. Rio de Janeiro: Civilização Brasileira, 1968.

GLACKEN, Clarence J. Huellas en la playa de Rodas. Naturaleza y cultura en el pensamiento occidental desde la Antiguedad hasta finales des siglo XVIII. Barcelona: Ediciones del Serbal, 1996.

GREENBIE, Barrie B. The Landscape of Social Symbols. In: NASAR, Jack L. (Edt.). Environmental Aesthetics. Theory, Research \& Applications. Cambridge:

Cambridge University Press, 1988, p. 64-73.

GOMES, Edvânia Torres Aguiar. Agendando velhos reencontros: relações entre os humanos e a natureza nos espaços socialmente produzidos. In: SPOSITO, M.E.B. (Org.). Urbanização e cidades. Perspectivas geográficas. Presidente Prudente:

UNESP/GAsPERR, 2001 p. 231-251.

GULLAR, Ferreira. Toda poesia 1950-1999. Rio de Janeiro: Ed. José Olympio, 2001 (11a ed.). 
HABERMAS, Jürgen. Técnica e ciência como "ideologia". Lisboa: Edições 70, 1997.

HARVEY, David. Social Justice and the City. Baltimore: The Johns Hopkins University Press, 1973.

HARVEY, David. Justice, Nature and the Geography of Difference. Oxford: Blackwell Publishers ltd, 1996.

HARVEY, David. Spaces of Hope. Berkley: University of California Press, 2000.

HARVEY, David. Spaces of Capital. Towards a Critical Geography. New York: Routledge, 2001.

HENRIQUE, Wendel. Zoneamento ambiental: uma abordagem geomorfológica. Rio Claro: IGCE/UNESP, 2000. (Dissertação de Mestrado)

HENRIQUE, Wendel. O Direito à Natureza na Cidade. Ideologias e práticas na bistória. Rio Claro: IGCE/UNESP, 2004. (Tese de Doutorado)

HOWARD, Ebenezer. Cidades-Jardins de amanhã. São Paulo: Hucitec, 1996.

HOLANDA, Sérgio Buarque de. Raizes do Brasil. 5a. ed. Rio de Janeiro: José Olympio Editora, 1969.

HUMBOLDT, Alexander von. Quadros da natureza. Rio de Janeiro: W. M. Jakcson, 1953. v. I e II.

JAPIASSU, Hilton. Introdução ao pensamento epistemológico. 2.ed. Rio de Janeiro: Francisco Alves Editora, 1977.

KOSIK, Karel. Dialética do concreto. 2. ed. Rio de Janeiro: Paz e Terra, 1976.

LE CORBUSIER. Carta de Atenas. www.rc.unesp.br/planejamento.

LE CORBUSIER. Urbanismo. 2. ed. São Paulo: Martins Fontes, 2000.

LEFEBVRE, Henri. O direito a cidade. São Paulo: Difel, 1969.

LEFEBVRE, Henri. Lógica forma/lógica dialética. 5.ed. Rio de Janeiro: Civilização Brasileira, 1995.

LENOBLE, Robert. História da ideia de natureza. Lisboa: Edições 70, 1969.

LOUREIRO, Claudia \& AMORIM, Luiz . Dize-me teu nome, tua altura e onde moras e te direi quem és: estratégias de marketing e a criação da casa ideal Parte I. Arquitextos, 057, fevereiro 2005 acessado a partir do Portal Vitruvius (www.vitruvis.com.br)

LUGINBUHL, Yves. "Nature, paysage, environnement, obscurs objetcs du désir de totalité". In: ROBIC, Marie-Claire (dir.). Du Milieu a L'Environnement-pratiques et représentation du rapport homme/nature depuis la Renaissance. Paris:

Economica, 1992, p. 11-56. 
LUKACS, Georg. Historia e consciência de classe: estudos de dialéctica. Porto: Escorpião, 1974.

LUKACS, Georg. Existencialismo ou marxismo. São Paulo: Ciências Humanas, 1979.

MANDEL, Ernest. O capitalismo tardio. 2.ed. São Paulo: Nova Cultural, 1985.

(coleção Os Economistas)

MARSH, George Perkins. Man and Nature: or Physical Geography as modified by Human action. New York: Charles Scriber, 1874.

MARSH, George Perkins. Man and Nature. Cambridge: Harvard University Press, 1965.

MARX, Karl \& ENGELS, Friedrich. A ideologia alemã. 4. ed. Portugal: Editorial Presença, 1980, v. I e II.

MARX, Karl. Manuscritos econômico-filosóficos. In: FROMM, Erich. Conceito marxista de homem. 2. ed. Rio de Janeiro: Zahar Editores, 1962.

MARX, Karl. O capital. 6. ed. Rio de Janeiro. Civilização Brasileira, 1980, livro I, v. I e II.

MARX, Karl. Para a crítica da economia política. São Paulo: Nova Cultural, 1999 (Coleção Os Pensadores).

MENDES, Armando Dias. Breve itinerário dos ecossistemas à ecoposia. In: BURSZTIYN, Marcelo (Org.). Para pensar o desenvolvimento sustentável. São Paulo: Ed. Brasiliense, 1993, p.11-28.

MUMFORD, Lewis. A cidade na história. Suas origens, transformações e perspectivas. 4. ed. São Paulo: Martins Fontes, 1998.

ORTEGA y GASSET. Que é filosofia? Rio de Janeiro: Livro Ibero-Americano, 1971.

ORTEGA y GASSET, J. An Interpretation of Universal History. New York: W.W. Norton \& Cia. Inc., 1973.

RECLUS, Élisée. La Terre: description des phénoménes de la vie du globe. Paris: Hachete, 1874, v.I (Les continents).

RÉCLUS, Élisée. A New Physical Geography. New York: D. Appleton \& Company, 1886, v. II (The Ocean, Atmosphere and Life).

RECLUS, Élisée. L'Homme et la Terre. 2.ed. Paris: Albin Michel, 1930. Tomos I, II e III.

RECLUS, Élisée. Coletânea (ANDRADE, Manuel Correia de, Org.). São Paulo: Editora Ática, 1985.

RECLUS, Élisée. Du sentiment de la nature dans le societés modernes et autres textes. Paris: Édition Premières Pierres, 2002 (Anthologie par Joël Cornuault). 
RODRIGUES, Arlete Moysés. Produção do espaço e ambiente urbano. In: SPOSITO, M.E.B. (Org.). Urbanização e cidades. Perspectivas geográficas. Presidente Prudente: UNESP/GAsPERR, 2001, p. 211-230.

SALDANHA, Nelson. O jardim e a praça. O privado e o público na vida social e bistória. São Paulo: Edusp, 1993.

SANTOS, Milton. A cidade nos países subdesenvolvidos. Rio de Janeiro: Civilização Brasileira, 1965.

SANTOS, Milton. Por uma geografia nova. São Paulo: Hucitec/Edusp, 1978.

SANTOS, Milton. O espaço dividido. Os dois circuitos da economia urbana dos países subdesenvolvidos. Rio de Janeiro: Livraria Francisco Alves, 1979. (345p)

SANTOS, Milton. A natureza do espaço - técnica e tempo, razão e emoção. 3. ed. São Paulo: HUCITEC, 1999.

SANTOS, Milton. Ensaios sobre a urbanização latino-americana. São Paulo: Editora Hucitec, 1982.

SANTOS, Milton. Espaço E método. São Paulo: Nobel, 1985.

SANTOS, Milton. Metamorfoses do espaço habitado. São Paulo: Hucitec, 1988.

SANTOS, Milton (Org.) Novos rumos da geografia brasileira. 4. ed. São Paulo: Editora Hucitec, 1996.

SANTOS, Milton. Pensando o espaço do homem. 4.ed. São Paulo: Editora Hucitec, 1997.

SANTOS, Milton. Território e sociedade. Entrevista com Milton Santos. 2. ed. São Paulo: Editora Fundação Perseu Abramo, 2000a.

SANTOS, Milton. O espaço do cidadão. 5. ed. São Paulo: Nobel, 2000b

SANTOS, Milton. Por uma outra globalização - do pensamento único à consciência universal. 2 ed. Rio de Janeiro: Ed. Record, 2000c.

SANTOS, Milton. Conferência Magna, 2000d (mimeo)

SANTOS, Milton e SILVEIRA, Maria Laura. O Brasil: território e sociedade no início do século XXI. São Paulo: Editora Record, 2001.

SÃO PAULO (Prefeitura). Atlas ambiental de São Paulo. São Paulo: PMSP, 2003.

SCHAMA, Simon. Paisagem e memória. São Paulo: Companhia das Letras, 1996.

SCHMIDT, Alfred. El Concepto de naturaleza en Marx. Espanha: Siglo Veinteuno Editores, 1976.

SEGAWA, Hugo. Ao amor do público. Jardins no Brasil. São Paulo: Studio Nobel, 1996. 
SERRES, Michel. Contrato natural. Rio de Janeiro: Nova Fronteira, 1991.

SMITH, Neil. Desenvolvimento desigual. Natureza, capital e a produção do espaço. Rio de Janeiro: Bertrand Brasil, 1988.

SOPER, Kate. What is nature? Culture, Politics and the non-human. Oxford: Blackwell, 2000.

SOUZA, Maria Adélia Aparecida de. A identidade da Metrópole. A verticalização de São Paulo. São Paulo: Hucitec/EDUSP, 1994.

SOUZA, Gustavo de Oliveira Coelho de. Cidade, meio ambiente e modernidade. In: SPOSITO, M.E.B. (Org.). Urbanização e cidades. Perspectivas geográficas:

UNESP/GAsPERR, 2001, p. 253-279.

THOMAS, Keith. O homem e o mundo natural. São Paulo: Cia. das Letras, 1996.

WHITEHEAD, Alfred North. The Concept of Nature. Cambridge: University Press, 1955. 



\section{Colofão}

\begin{tabular}{|c|c|}
\hline Formato & $17 \times 24 \mathrm{~cm}$ \\
\hline Tipologia & Gatineau \\
\hline Papel & $\begin{array}{l}75 \mathrm{~g} / \mathrm{m}^{2} \text { (miolo) } \\
\text { Cartão Supremo } 250 \mathrm{~g} / \mathrm{m}^{2} \text { (capa) }\end{array}$ \\
\hline Impressão & Setor de Reprografia da EDUFBA \\
\hline Capa e Acabamento & Gráfica Cian \\
\hline Tiragem & 500 exemplares \\
\hline
\end{tabular}

